\title{
PAST, PRESENT AND FUTURE MORPHOLOGICAL DEVELOPMENT OF A TSUNAMI-AFFECTED COAST
}

\author{
A case study of Banda Aceh
}

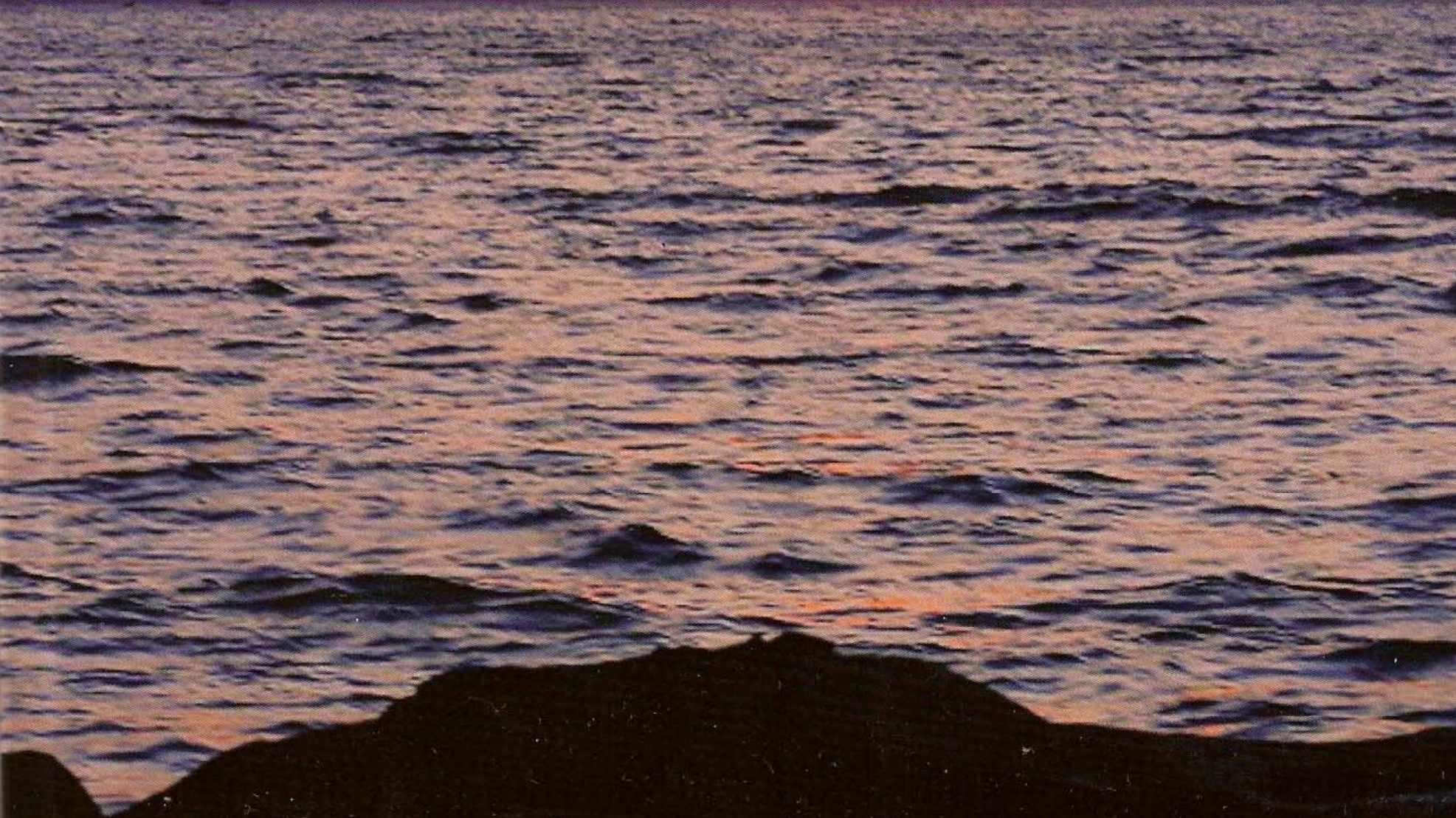

Ella Meilianda 
In memory of the tsunami on 26 December 2004 

PAST, PRESENT AND FUTURE MORPHOLOGICAL DEVELOPMENT OF A TSUNAMI- AFFECTED COAST

A CASE STUDY OF BANDA ACEH 
Promotion Committee:

prof.dr. F. Eising prof.dr. S.J.M.H. Hulscher

dr.ir. C.M. Dohmen-Janssen

dr. B.H.P. Maathuis

dr.ir. D.C.M. Augustijn

prof.ir. E. van Beek

prof.dr. P. Hoekstra

dr. Wong Poh Poh

prof.dr. S.B. Kroonenberg
University of Twente, chairman dan secretary

University of Twente, promotor

University of Twente, assistent-promotor

ITC, Referee

University of Twente

University of Twente

Utrecht University/IMAU

National University of Singapore

TU Delft

The research described in this thesis was undertaken at the Water Engineering and Management Department, Faculty of Engineering Technology, University of Twente (UT) and was co-registrated at the International Institute for Geoinformation Science and Earth Observation (ITC), Enschede, The Netherlands. The research was funded largely by the Asian Development Bank (ADB) through the TPSDP Project - Syiah Kuala University, Banda Aceh, Indonesia. The final phase of the research was funded by the Institute of Governance Studies (IGS), University of Twente, Enschede, the Netherlands.

Cover: 'Senja di Ulee Lheue' by Dedy Alfian

Copyright (C) 2009 by Ella Meilianda, Enschede, the Netherlands

Printed by Gildeprint, Enschede, the Netherlands

ISBN 978-90-365-2829-0 


\title{
PAST, PRESENT AND FUTURE MORPHOLOGICAL DEVELOPMENT \\ OF A TSUNAMI- AFFECTED COAST
}

\section{A CASE STUDY OF BANDA ACEH}

\author{
DISSERTATION
}

\author{
to obtain \\ the doctors degree at the University of Twente, \\ on the authority of the rector magnificus, \\ prof.dr. H. Brinksma, \\ on account of the decision of the graduation committee, \\ to be publicly defended \\ on Friday 19 June 2009 at 15:00 \\ by \\ Ella Meilianda \\ born on 30 May 1975 \\ in Banda Aceh, Indonesia
}


This dissertation has been approved by:

prof. dr. S.J.M.H. Hulscher

dr. ir. C.M. Dohmen-Janssen promotor

assistent-promotor 


\section{CONTENTS}

Summary

Samenvatting (Summary in Dutch)

Ringkasan (Summary in Indonesian)

1 Introduction

1.1 Problem definition and objective

1.2 Location of study area

1.3 Research questions and methodologies

1.4 Thesis outline

2 Geomorphological outline of Banda Aceh coast and the impact of the tsunami of 26 December 2004

Abstract

2.1 Introduction

2.2 Study site and data sets

2.2.1 Study site

2.2.2 Methods and data sources

2.3 Development on the geological time-scale

2.3.1 Oligocene to Early Miocene (32 to 23 my BP)

2.3.2 Early Miocene to Middle Miocene (23 to $15 \mathrm{my} \mathrm{BP}$ )

2.3.3 Middle Miocene to Late Pliocene (15 my BP to 3 my BP)

2.3.4 Late Pliocene to early Pleistocene ( $3 \mathrm{my}-1.7 \mathrm{my})$

2.3.5 Pleistocene - mid Holocene (1.7 my - 5.5 ky BP)

2.4 Morphological development in millennial to centennial time-scale

2.4.1 Sea level during the Holocene

2.4.2 Regional climate conditions and sedimentation during the Holocene

2.4.3 Banda Aceh coastal plain shoreline of 4.0 ky BP

2.4.4 Banda Aceh coastal plain shorelines of $3.5 \mathrm{ky}$ BP and $2.8 \mathrm{ky} \mathrm{BP}$

2.4 .5 Banda Aceh coastal plain shorelines of $1.1 \mathrm{ky}$ BP and $0.6 \mathrm{ky}$ BP $\ldots . . .$.

2.5 Coastal evolution near Banda Aceh over the past century

2.5.1 Recent morphology and data processing

2.5.2 Shoreface morphology over the past century

2.6 Discussion

2.6.1 Forcing factors in history of morphological development of Banda Aceh

2.6.2 Remarks on the tsunami return period in a long time-scale ...........

2.6.3 Tsunami impact against different coastal geomorphic settings .........

2.7 Conclusions

3 Short-term morphological response and development of the Banda Aceh coast, Sumatra Island, Indonesia after the tsunami on 26 December 2004

Abstract

3.1 Introduction

3.2 Study locations and data overview

3.2.1 Study locations
Page

11

15

19

23

23

26

29 


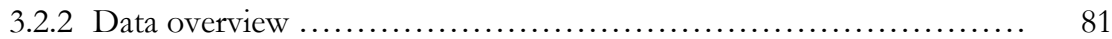

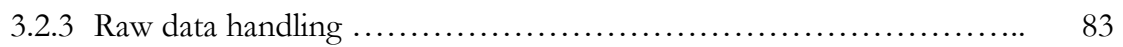

3.2.4 Dealing with spatial resolution difference and data gaps ............ 84

3.2 .5 Data uncertainty .............................................. 84

3.2.6 Observations on land subsidence .............................. 85

3.3 Foreshore development study .......................................... 85

3.3.1 Multi-shoreline identification ................................ 85

3.3.2 Quantification of sediment volume changes in the foreshore zone .... 90

3.4 Digital Elevation Models (DEMs) of shoreface development at Ulee Lheue 95

3.4.1 Input data and methods ................................... 95

3.4.2 Morphological development of the shoreface .................... 96

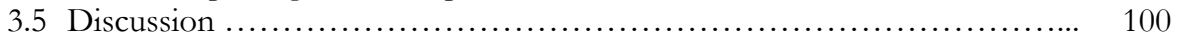

3.5.1 Influence of the coastal geomorphic settings .................... 100

3.5.2 Influence of land subsidence to the coastal morphological 103

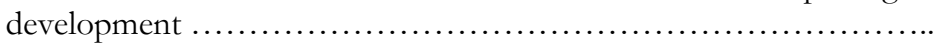

3.6 Conclusions

4 Scenarios for future development of a sand-poor coastal environment 105 subject to tectonic and tsunami events

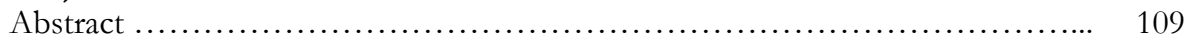

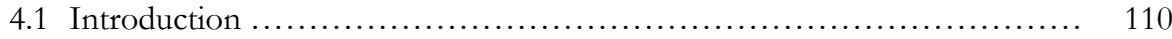

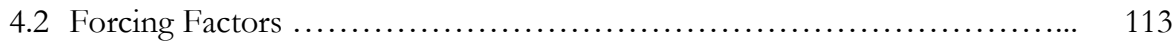

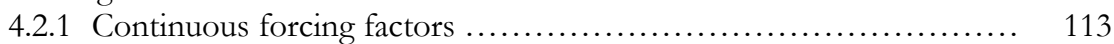

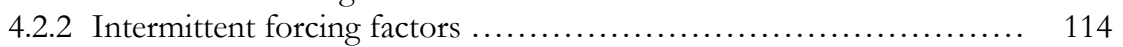

4.3 Shoreline evolution in the past century .......................... 118

4.3.1 Defining spatial boundaries of the active part of a coastal system over 118 a-hundred-years time scale

4.3.2 Selection of coastal cells at Banda Aceh coast ..................... 119

4.3.3 Analysis of historical shoreline evolution and the intermittent forcing 124 factors

4.4 Scenarios for future coastal development: coupling continuous and intermittent forcing factors

4.4.1 Sediment budget analysis

4.4.2 Scenarios for coastal morphological development in the next century

4.5 Discussions

4.5.1 Tectonically unstable coastal region (cell 1; Lambadeuk coast) ........

4.5.2 Tectonically stable coastal region (cells 2 and 3; Kuala Gigieng and Neuheun)

4.5.3 Implications of the tsunami and land subsidence effect on the sand- 151 poor coastal environment

4.6 Conclusions

\section{Discussion}

5.1 Synthesis of the morphological development at the Banda Aceh coast

5.2 Short term development since earthquake and tsunami of December $2004 \quad 158$

5.3 Influence of tectonic land subsidence and tsunami compared to the effect 160 of climate change in future morphological development

5.4 Issues on uncertainty and methodology ....

5.5 Generalization and application of the present study 
6 Conclusions and recommendations 167

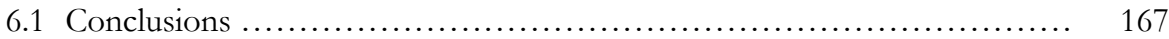

6.2 Recommendations ....................................................... 171

References $\quad 172$

Acknowledgements 181

List of Publications $\quad 185$

$\begin{array}{ll}\text { About the author } & 187\end{array}$ 


\section{Summary}

This thesis provides a comprehensive analysis to increase the understanding of the future development of a coastal system that is prone to the large-scale natural interventions of tectonic land subsidence and tsunami. It analyses the morphological response and development of Banda Aceh, a coast which was affected by the large magnitude earthquake occurring on 26 December 2004 in the Indian Ocean. Based on the fact that little was known about the forcing factors involved in the geomorphologic history of the Banda Aceh coastal plain, we set more specific objectives to fill in the gap of knowledge about this study area by investigating the forcing factors and geomorphic settings of the coast in general, as well as the magnitude and frequency of tsunami and land subsidence occurrences that were involved in shaping the morphology of this specific coastal area in the history. This information is subsequently used to set some scenarios of morphological development in future.

The research in this thesis rested on the notion that older morphological units can be identified to some extent in the present coastal morphology. Each older morphological unit provides a boundary for the more recent units and therefore co-determines the more recent morphological developments. We argue that in a short-term, a coastal development constitutes the foreshore development which asymptotically reached a short-term equilibrium. Moreover, the sediment characteristics and availability determine the trend of morphological development of the coast after the intermittent event such as a tsunami and a land subsidence.

The longer the time scale being considered, the more forcing factors with different frequencies are involved in the coastal morphological development. In a tectonically active region, sudden or rapid land uplift or subsidence resulting from the vertical tectonic movements and the resulting tsunamis are considered as the intermittent forcing factors involved in a hundred-year time scale. At the same time, littoral sediment transport induced by wave actions (continuous forcing factors) plays an important role for the development of the coastal morphology. Shoreline position and orientation are two important parameters to take into account in determining the state of a coast; whether it is an eroding or an accreting coast. As a result of the sudden impact of a tsunami or a land subsidence, the shoreline position and orientation as well as the shoreface morphology may change 
considerably. These changes lead to a new coastal state and determine the subsequent morphological development.

This thesis took the explorative methodologies and emerged the timescale-related issues on the coastal morphological processes related to the earthquakes and the related tsunami and land subsidence. The flow of the research was driven by a wide span of geomorphological interpretation, field observations, spatial data analysis from satellite images, topographic and bathymetric maps, analysis of forcing factors magnitudes and frequencies as well as sediment budget analysis of the littoral transport. The integration of various approaches providing available data sets was done to achieve the essential knowledge about the study area by filling in the gaps of knowledge both on the geomorphic settings and the forcing factors involved in the morphological development.

Banda Aceh coast is a sand-poor environment contains only a thin layer of loose sand on top of a consolidated Holocene prograding delta. The earthquake and tsunami of 26 December 2004 also affected the morphological units that have been established in the Holocene period. The seawater inundated to the coastal plain as far inland as the shoreline position of $0.6 \mathrm{ky} \mathrm{BP}$, during which a similar magnitude of tsunami confirmed to have occurred. The responses of shoreface profiles to the tsunami waves were different from one profile to another due to different geomorphic settings. This shows that such huge tsunami and the accompanying land subsidence effect occurred instantaneously, but it led to changes in morphology comparable to changes that normally occur on the time scale of century to millennia.

Two coasts of different geomorphic settings and sediment characteristics were investigated for the short-term analysis; i.e. Ulee Lheue, on the northwest coast and Lampu Uk on the west coast of Banda Aceh. In the early days after the tsunami, both coasts experienced foreshore morphological adjustment, revealed by the smoothening shoreline undulations and foreshore slope. After 6 months they showed opposite trend from their pre-tsunami positions. Ulee Lheue, on the northwest coast, experienced ongoing erosion of about $15 \%$ of the total sediment loss due to the tsunami. The ongoing shoreline retreat at Ulee Lheue after the December 2004 tsunami suggests that the extent of coastal erosion and the lack of sediment supply in the littoral zone after the tsunami could not keep the pace with the sudden change of coastal elevation due to the land subsidence. As a result, the shoreline was retreating even further. At Lampu Uk, on the west coast, $60 \%$ of sediment loss due to the tsunami gained back to the coast after 6 months, and a remarkable pile of sand was accumulated on the backshore after two years since 
the tsunami. The width and the slope gradient of the shoreface and inner shelf as well as the sediment availability and characteristics in front of each coast control this contrasting behaviour. The amount of re-distributed sediment back to the shore may have exceeded the magnitude of the elevation difference caused by the land subsidence.

Both earthquakes and tsunamis have remarkable impacts on the coastal morphology and its future development. The long-term trend of coastal development may be interrupted, which also means that a long-term equilibrium condition may not exist. At an accreting and tectonically stable coast (e.g. Kuala Gigieng) the rate of advancing shoreline is halted due to the expected effect of sealevel rise, and can be further halted by the effect of erosion by the intermittent tsunami events. On the other hand, at an eroding and tectonically unstable coast (e.g. Lambadeuk), the sea-level rise increases the rate of shoreline retreat, and can further be exacerbated by the effect of land subsidence which may cause an irreversible shoreline retreat, especially in the sand-poor coastal environment.

This thesis suggests that the damage caused by the probable recurrence of tsunami and land subsidence events to the coastal morphology within a century can be an order of magnitude greater than the effect of the well-known sea-level rise due to global climate change, which is often considered important in modern coastal management practices. In this way, we built a sound coastal morphological foundation to inform important aspects necessary to be taken into account in the coastal engineering and management practices for the tectonically active coastal region. 


\section{Samenvatting (summary in Dutch)}

Dit proefschrift verstrekt een uitvoerige analyse om het begrip van de toekomstige ontwikkeling van een kustsysteem dat is onderheven aan grootschalige natuurlijke interventies door tektonische daling en tsunami's te verhogen. Het bespreekt de morfologische respons en ontwikkeling van Banda Aceh, een kustgebied dat is getroffen door de zware aardbeving in de Indische oceaan op 26 december 2004. Gebaseerd op het feit dat weinig bekend was over de bepalende factoren betrokken bij de geomorfologische geschiedenis van de kustvlakte van Banda Aceh, zijn hier specifiekere doelstellingen bepaald om het hiaat van kennis over dit studiegebied in te kunnen vullen. Dit is gedaan door zowel de invloed van externe bepalende factoren en de algemene geomorfologie van het gebied zelf te onderzoeken, evenals de omvang en de frequentie van tsunami's en tektonische landdaling die invloed gehad hebben op de morfologische ontwikkelingen van dit gebied in het verleden. Deze informatie is vervolgens gebruikt om scenario's te schetsen voor de toekomstige morfologische ontwikkeling.

Het werk in dit proefschrift is gebaseerd op het gegeven dat oudere morfologische eenheden tot op zekere hoogte geïdentificeerd kunnen worden in de huidige morfologie. Elke oudere eenheid functioneert als een grenslaag voor de jongere eenheden en draagt daarmee bij aan het identificeren van de meer recente morfologische ontwikkelingen. Wij stellen dat op de korte termijn de kustontwikkeling de ontwikkeling van de vooroever vormt, welke op asymptotische wijze richting een korte termijn evenwicht gaat. Bovendien bepalen de eigenschappen en beschikbaarheid van sediment de trend van de morfologische ontwikkeling van de kust nadat een ingrijpend voorval als een tsunami en bijbehorende landdaling heeft plaatsgevonden.

Hoe langer de tijdsschaal is die in beschouwing wordt genomen, hoe meer factoren met verschillende frequenties bepalend zijn voor de morfologische ontwikkeling van een gebied. In een tektonisch actief gebied worden abrupte en snelle opheffing en daling van het land als gevolg van verticale tektonische bewegingen, en de daarbij voorkomende tsunami's, beschouwd als de intermitterend bepalende factoren in een honderdjarige tijdsschaal. Tegelijkertijd speelt in de kustzone sediment transport door golven (een continue bepalende factor) een belangrijke rol bij de ontwikkeling van de morfologie in dit gebied. Zowel de positie als de oriëntatie van de kustlijn zijn twee belangrijke parameters 
die in beschouwing genomen moeten worden bij de bepaling van de toestand van een kust; of deze erodeert of aangroeit. Als gevolg van de acute invloed van een tsunami of tektonische landdaling, kunnen de positie en oriëntatie van een kustlijn, evenals de morfologie van het strand, aanzienlijk veranderen. Deze veranderingen leiden tot een nieuwe toestand van de kust en zijn bepalend voor de verdere morfologische ontwikkeling.

In dit onderzoek is gebruik gemaakt van een explorative benadering, wat de problematiek met betrekking op de tijdsschalen van de morfologische kustprocessen, gerelateerd aan aardbevingen (met de bijbehorende tsunami's en landdalingen) naar boven heeft gehaald. Het onderzoek is gedreven door een grote variëteit aan geomorfologische interpretaties, veld observaties, ruimtelijke data analyse van satelliet beelden, topografische en bathymetrische kaarten, analyse van frequenties en dimensie van bepalende factoren en sediment budget analyses van het kust gerelateerde transport. Het integreren van verschillende benaderingen en datasets is gedaan om hiaten te kunnen dichten in de essentiële kennis over de invloed van zowel de geomorfologische omstandigheden, als de bepalende factoren op de geomorfologische ontwikkeling.

Banda Aceh is een zandarm gebied met slechts een dunne laag van los zand, bovenop een geconsolideerde prograderende Holocene delta. De aardbeving en tsunami van 26 december 2004 hebben ook de morfologische eenheden van deze Holocene periode aangetast. Het zeewater heeft de kustvlakte overstroomd tot aan het niveau van de kustlijn op 0.6 ky BP, het moment dat een vergelijkbare tsunami het gebied heeft getroffen. Als gevolg van de verschillende geomorfologische omstandigheden varieert de reactie van het kustgebied op de tsunami golf tussen verschillende locaties, wat duidelijk is in verschillende strandprofielen. Deze laten ook zien dat een tsunami met een dergelijke afmeting, en de bijbehorende tektonische landdaling, een ogenblikkelijk effect heeft en leidt tot veranderingen in de morfologie die normaal voorkomen op de tijdsschaal van eeuwen tot millennia.

Voor de korte termijn analyse zijn 2 kustgebieden met verschillende morfologische en sedimentaire kenmerken onderzocht, te weten Ulee Lheue and de noordwest kust van Banda Aceh en Lampu Uk aan de west kust. In de dagen na de tsunami ondergingen beide kustgebieden een morfologische verandering van het strand en de vooroever. Dit kwam tot uiting in een vervlakking van onregelmatigheden in de helling van de kustprofielen. $\mathrm{Na} 6$ maanden werd tussen de beide kustgebieden een tegengestelde trend waargenomen in vergelijking met de positie van voor de tsunami. Ulee Lheue, aan de noordwest kust, onderging een 
voortdurende erosie van ongeveer 15\% van het totaal verloren sediment door de tsunami. De voortdurende terugtrekking van de kustlijn in Ulee Lheue na de december 2004 tsunami, suggereert dat de omvang van kust erosie en het gebrek aan nieuw aangevoerd sediment in de kustzone na de tsunami, er voor zorgden dat de plotselinge verlaging van het kustgebied als gevolg van tektonische landdaling niet gecompenseerd kon worden. Als gevolg hiervan vond verdere terugtrekking van de kustlijn plaats. In Lampu Uk, aan de westkust, was na 6 maanden $60 \%$ van het sediment dat verloren was als gevolg van de tsunami weer terug in het gebied en sinds 2 jaar na de tsunami vind een opvallende opeenhoping van zand plaats aan de landzijde van het strand. De breedte en hellingsgradiënt van het strand en vooroever evenals de beschikbaarheid van sediment en kenmerken van de kust, bepalen dit tegengestelde gedrag. De hoeveelheid opnieuw verdeeld sediment terug naar de kust, kan de mate van hoogteverschil veroorzaakt door de tektonische landdaling overschreden hebben.

Zowel aardbevingen als tsunami's hebben opmerkelijke invloeden op de kustmorfologie en de toekomstige ontwikkeling ervan. De lange termijn trend van de kustontwikkeling kan hierdoor onderbroken worden, wat ook betekent dat een lange termijn evenwichtsconditie wellicht niet voorkomt. In het geval van een groeiende en tektonisch stabiele kust (bijv. Kuala Gigieng) wordt de snelheid waarmee de kustlijn zeewaarts verschuift vertraagd door het verwachte effect van zeespiegelstijging, en dit kan verder gestopt worden door het effect van erosie door intermitterende tsunami's. Aan de andere kant, bij een eroderende en tektonisch onstabiele kust (bijv. Lambadeuk), kan zeespiegelstijging een toename van terugtrekking van de kustlijn veroorzaken, en daarnaast kan dit verergerd worden door het effect van landdaling, wat een onomkeerbare terugtrekking van de kustlijn kan veroorzaken, in het bijzonder in combinatie met een zandarm kustmilieu.

In dit proefschrift wordt verondersteld dat de schade die aangericht wordt door een mogelijk herhaald voorkomen van tsunami's en tektonische landdaling op de kust morfologie, binnen een eeuw van een orde groter kan zijn dan het effect van de welbekende zeespiegelstijging als gevolg van wereldwijde klimaatverandering. Alhoewel vaak met name dit laatste effect in huidige kust projecten als belangrijk wordt verondersteld. Wij construeerden hier een correcte basis voor belangrijke aspecten met betrekking tot kustmorfologie welke in beschouwing genomen zouden moeten worden bij de technische en organisatorische projecten in tektonisch actieve kustgebieden. 


\section{Ringkasan (Summary in Indonesian)}

Tesis ini memberikan analisis yang komprehensif untuk meningkatkan pemahaman terhadap perkembangan dari sistem suatu pantai di masa yang akan datang yang rentan terhadap interfensi alam dalam skala besar yaitu penurunan massa daratan akibat tektonik dan tsunami. Tesis ini mengemukakan respon dan perkembangan morfologi dari Banda Aceh, yaitu pantai yang terkena dampak tersebut akibat bencana gempa yang terjadi pada tanggal 26 Desember 2004 di Laut Hindia. Berdasarkan fakta bahwa sangat sedikit yang diketahui tentang faktor-faktor tenaga yang terlibat dalam sejarah geomorfologi dataran pantai Banda Aceh, kami menentukan tujuan spesifik dari tesis ini yaitu untuk mengisi celah pengetahuan tentang lokasi studi ini dengan cara menginvestigasi faktor-faktor tenaga dan bentukan geomorfik dari wilayah pantai tersebut secara umum, dan juga besaran dan frekuensi dari kejadian tsunami dan penurunan massa daratan yang terlibat dalam pembentukan morfologi pantai ini secara spesifik di masa lalu. Informasi ini kemudian digunakan untuk menentukan berbagai scenario perkembangan morfologi pantai di masa datang.

Metodologi yang diterapkan dalam tesis ini berdasarkan pada pandangan bahwa unit-unit morfologi terdahulu dalam cakupan tertentu dapat diidentifikasikan pada morfologi pantai saat ini. Setiap unit morphologi terdahulu menyediakan suatu batasan bagi unit-unit selanjutnya dan oleh karena itu juga menentukan perkembangan morfologi pada masa selanjutnya. Kami berpendapat bahwa dalam jangka waktu pendek, perkembangan suatu wilayah pantai melibatkan perkembangan morfologi pantai (foreshore) yang akan mencapai suatu kesetimbangan jangka pendek secara asimtotik. Kemudian, karakteristik dan ketersediaan sediment menentukan tren dari perkembangan morfologi pantai tersebut setelah kejadian yang sesaat seperti karena dampak tsunami dan penurunan masa daratan.

Semakin panjang skala waktu yang dipertimbangkan, semakin banyak pula faktor-faktor tenaga dengan frekuensi berbeda yang terlibat dalam perkembangan morfologi pantai. Di suatu wilayah yang aktif secara tektonik, kenaikan atau penurunan massa daratan yang tiba-tiba atau cepat akibat pergerakan tektonik secara vertical dan kejadian tsunami dalam hal ini dianggap sebagai factor-faktor tenaga sesaat (intermittent) yang terlibat dalam jangka waktu seabad. Pada saat yang ksama, transport sediment litoral ditimbulkan oleh gaya gelombang (factor tenaga 
kontinyu) memainkan peranan penting dalam perkembangan morfologi wilayah pantai tersebut. Posisi dan orientasi garis pantai adalah dua parameter penting yang harus diperhitungkan dalam menentukan status pantai tersebut; apakah ia pantai yang tererosi atau yang terakresi. Sebagai hasil dari dampak sesaat dari tsunami dan penurunan massa daratan, posisi dan orientasi garis pantai dan juga morfologi dari perairan pantai (shoreface) menjadi sangat berubah. Perubahan ini menjurus kepada status pantai yang baru dan menentukan perkembangan morfologi untuk tahap lebih lanjut.

Tesis ini menggunakan pendekatan eksploratif dan mengaitkan hubungan antara permasalahan dalam hal jangka waktu dari proses morfologi pantai dan gempa dan tsunami serta penurunan massa daratan yang berkaitan. Laju penelitian dikendalikan oleh cakupan yang luas dari interpretasi geomorfologi, observasi lapangan, analisa data spatial dari citra-citra satelit, peta-peta topografi dan kedalaman laut, analisa terhadap besaran dan frekuensi dari faktor-faktor tenaga terkait dan juga analisa imbangan sediment di wilayah litoral.

Pantai Banda Aceh adalah sebuah lingkungan pantai yang kurang asupan sedimen dan hanya terdiri dari lapisan pasir lepas di atas bentukan delta di masa Holocene yang telah terkonsolidasi. Gempa dan tsunami Desember 2004 juga mempengaruhi unit-unit morfologi yang telah terbentuk sejak periode Holocene tersebut. Air laut menggenangi wilayah dataran pantai sejauh posisi garis pantai yang terbentuk pada masa 600 tahun sebelum saat ini (0.6 ky BP), dimana pada masa tersebut kejadian tsunami dengan besaran yang serupa pernah terjadi. Respon profil perairan pantai (shoreface) terhadap gelombang tsunami berbeda dari satu profil ke profil lainnya akibat adanya perbedaan bentukan geomorfik dari profilprofil tersebut. Ini menunjukkan bahwa dampak dari tsunami yang dahsyat ini dan efek penurunan massa daratan yang terkait terjadi secara instant, namun hal ini menimbulkan perubahan morfologi yang sebanding dengan perubahan yang seharusnya terjadi dalam kurun waktu seabad hingga ribuan tahun dalam kondisi normal.

Dua lokasi pantai yang mempunyai bentukan geomorfik dan karakteristik sedimen yang berbeda dianalisa untuk kurun waktu singkat; yaitu Ulee Lheue, sebuah pantai di sebelah barat daya dan Lampu Uk, sebuah pantai di sebelah barat kota Banda Aceh. Beberapa hari setelah kejadian tsunami, kedua pantai tersebut mengalami penyesuaian morfologi di bagian pantai, dapat dilihat dari pelurusan garis pantai dan dasar perairan pantai yang sebelumnya bergelombang. Setelah 6 bulan keduanya menunjukkan tren posisi garis pantai yang berlawanan terhadap posisi sebelum tsunami. Ulee Lheue mengalami erosi berkelanjutan sekitar 15\% 
dari total sedimen yang hilang akibat tsunami. Mundurnya garis pantai yang berkelanjutan sejak tsunami December 2004 ini menyarankan bahwa jangkauan erosi pantai dan kurangnya suplai sedimen di wilayah litoral setelah tsunami tidak mampu mengejar laju perubahan elevasi pantai yang tiba-tiba akibat terjadinya penurunan massa daratan. Sebagai hasilnya, garis pantai semakin mundur lebih jauh. Di Lampu Uk, 60\% dari kehilangan sedimen akibat tsunami kembali lagi ke pantai setelah 6 bulan, dan timbunan pasir yang cukup banyak terakumulasi di daerah sempadan pantai (backshore) dua tahun setelah tsunami. Lebar dan kemiringan dasar perairan pantai dan lepas pantai (innershelf) serta ketersediaan dan karakteristik sedimen di perairan pantai menentukan perilaku yang berlawanan ini. Jumlah dari sediment yang terdistribusi kembali ke wilayah pantai dapat melampaui besaran dari perubahan elevasi yang disebabkan oleh penurunan massa daratan.

Gempa dan tsunami memberikan dampak yang besar terhadap morfologi pantai dan perkembangannya di masa depan. Tren jangka panjang dari perkembangan pantai dapat terinterupsi, yang juga berarti bahwa kesetimbangan pantai dalam jangka panjang tidak akan tercapai. Di wilayah pantai yang terakresi dan stabil secara tektonik (mis. Kuala Gigieng) laju kemajuan pantai menjadi tertahan akibat dari efek kenaikan muka air laut, dan tertahan lebih jauh lagi oleh efek erosi yang disebabkan oleh kejadian tsunami. Di lain pihak, pada wilayah pantai yang tererosi dan tidak stabil secara tektonik (mis. Lambadeuk), laju kenaikan muka air laut dapat meningkatkan laju kemunduran garis pantai, dan dapat diperparah oleh adanya efek penurunan massa daratan yang mengakibatkan kemunduran pantai yang tidak dapat diperbaiki, terutama di lingkungan pantai dengan sedikit asupan sedimen.

Tesis ini menganjurkan bahwa kerusakan yang diakibatkan oleh kemungkinan terulangnya kejadian tsunami dan penurunan massa daratan pada morfologi pantai dalam sebuah abad dapat menjadi sepuluh kali lebih besar daripada efek dari kenaikan muka air laut yang mengemuka akibat perubahan iklim global, yang sering menjadi pertimbangan penting dalam praktik manajemen kepantaian modern. Dalam hal ini, kami telah membangun suatu pondasi morfologi pantai yang layak untuk menginformasikan aspek-aspek penting yang perlu diperhitungkan dalam rekayasa dan manajemen kepantaian untuk wilayah pantai yang aktif secara tektonik. 


\section{Chapter 1}

\section{Introduction}

\subsection{Problem definition and objective}

Natural hazards such as hurricanes, volcano eruptions, earthquakes and tsunamis may affect both coastal area and hinterland. Coasts around the world are densely populated areas which make them vulnerable, thus, high risk to natural hazards that sometimes inflict severe damage to properties and pose a threat to life in coastal communities. Hurricanes or cyclones can cause significant damage by the creation of powerful storm surges on coastal regions and also produce extensive coastal flooding further inland. Some of the most destructive hurricane events in the recent history are, for instance, the Gustave in the Caribbean Sea that struck Haiti in August 2008; The Nargis, in the Indian Ocean that struck Myanmar coast in May 2008; and the Katrina, in the Gulf of Mexico that struck Southern State of US in August 2005.

Submarine volcanic activities, on the other hand, can produce large earthquakes, massive subaqueous landslides and cause destructive tsunamis such as those caused by the eruption of Krakatau volcanic seamount in Sunda Strait, Indonesia in 1883; or the most recent submarine landslide in Papua New Guinea in 1998 (e.g. Borrero et al., 2003; Gelfenbaum and Jaffe, 2003; Satake and Tanioka, 2003; Sweet and Silver, 2003). In addition to the submarine volcanic eruptions and landslides, tsunamis are often triggered by powerful earthquakes associated with the vertical displacement of subducting tectonic plate boundaries under the ocean.

'Tsunami' is a Japanese term originating from the words 'tsu', meaning barbour, and 'nami', meaning wave. The nature of tsunamis remained poorly understood until the 20th century and is still the subject of ongoing research. Although the term is not accurate as it is used widely to describe such waves that are not limited to harbours, it remains the most recognized term for referring to the wave that is generated by an impulsive vertical tectonic displacement of the ocean floor, causing a similar displacement of the surface of the ocean. In Simeulue, a small island off the west coast of Aceh Province in Sumatra, such high waves have been recognized as "smong" through story-telling inherited throughout generations of Simeulue natives ever since they attacked the island's coast in 1907. In addition, tsunamis were also mistakenly seen as tidal waves. It is therefore logical to presume that if in the past century tsunami waves were misunderstood as 
harbour waves or tidal waves, the general knowledge regarding their impact on the coastal morphology must have been correspondingly problematic.

The NGDC-NOAA (2008) recently generated a worldwide earthquake and tsunami events database from various data sources which have been recorded extensively since ancient times, especially in Japan and the Mediterranean areas. The first recorded tsunami occurred off the coast of Syria in 2000 B.C. The Mediterranean and Caribbean Seas both have small subduction zones, and have histories of locally destructive tsunamis. Tsunamis have also been generated in Peru, Chile, New Guinea and the Solomon Islands. Only a few tsunamis have been generated in the Atlantic Ocean. The Alaskan tsunami in 1964 was remote-sourcegenerated tsunamis which affected the entire Pacific Ocean. In the Indian Ocean on 26 December 2004, a powerful earthquake off the coast of northern Sumatra generated a tsunami that was recorded nearly world-wide and killed more people than any other tsunami in recorded history.

Despite these, studies about tsunamis in relation to the earthquakes (that generated them) have started only in the recent century probably commencing with the study by Gutenberg (1939). It successively followed by studies of the occurrence of tsunamis due to tectonic activities and their impacts on the coastal areas around the world. Berninghausen (1962) and Soloviev and Go (1969) cited a tsunami which occurred in 1562 as the oldest recorded tsunami in the Pacific coast of South America. Abe, et al. (1986) and Borrero, et al. (1997) surveyed the impact of the Michoacan tsunami in Mexico in 1985. The impact of abnormal tsunami occurred in Japan in 1984 was investigated by Satake and Kanamori (1991), and the tsunami in Nicaragua in 1992 was investigated by Abe et al. (1993) and Kanamori and Kikuchi (1993). Noda et al. (2007) improved the understanding of the change in offshore sediment characteristics after the tsunami caused by the Tokachi-oki earthquake in Japan in 2003, by a combined approach of sediment sampling and modelling.

Worldwide awareness of the potential tsunami hazard to the coastal region has been increasingly growing since the occurrence of extraordinary earthquake leading to the tsunami of December 2004. This was reflected by increasing scientific works in the several regions affected by the 2004 tsunami to understand and to explain its impact to the coastal region. These studies mostly addressed the instantaneous impact of the tsunami to the coastal system by analysis of sub-aerial sediment distributions by the tsunami waves (Narayana et al., 2007; Paris et al., 2007); the reconstruction of the tsunami wave flow pattern (Gelfenbaum and Jaffe, 2003); the incision in the coastal morphology due to tsunami (Fagherazzi and Du, 
2007); and the impact of landforms on tsunami flow (Umitsu et al., 2007). Subaqueous sediment samples were studied at Lhoknga, west coast of Banda Aceh after the December 2004 tsunami estimates of the real-time sediment transport processes during the tsunami remain speculative (Paris et al., 2009; Paris et al., 2007).

Despite the growth of tsunami-related studies, there is little discussion on the morphological adjustment and development of the affected coast after the impact. Given the fact that such a powerful earthquake leading to such an extraordinary magnitude of tsunami is a rare event in human-life time history, and because it occurred only recently, there are ample knowledge gaps that hinder thorough investigations towards this level. Overall, the absence of this information results in a gap of knowledge, to forecast or to set-up future scenarios of the morphological development of the affected coasts.

The primary effect of tectonic activities is the displacement of the earth's crustal plates, either vertically or horizontally. Secondary effects may be the trigger of a tsunami due to the vertical displacements of crustal plates beneath a water body, the liquefaction of a mud layer due to intensive seismicity, as well as increasing intensity of volcanic activities. The objective of this study is to increase the understanding of how the large-scale natural interventions such as tsunami and tectonic land subsidence control the future development of the coastal morphology with different underlying geomorphic settings.

Understanding the cause, the extent of the changes as well as the subsequent development of the coast due to and after the earthquake and tsunami event may eventually be useful in setting up scenarios of the coastal development in the future. The knowledge can be applied, for instance, to a mitigation plan, a comprehensive master plan of evacuation-route and relocations or a rehabilitation plan of the devastated coastal region that remains to be prone to the earthquake and tsunami hazard in future. On the other hand, the main challenges to overcome in this thesis lies on the lack of readily available knowledge of the pre-existing geomorphology of the affected coast, and also of magnitudes and frequencies of the forcing factors (i.e. powerful earthquakes and tsunamis) involved in the hydrodynamics and morphodynamics processes in the time scales of interest. In addition, for a less-investigated study location such Banda Aceh coast, the pre- and post-event data were poorly archived.

The problem of having limited analysis on the response of a pre-existing coastal geomorphic setting (e.g. extent of the damage in comparison to that due to a hurricane) may lead to an erroneous setup of the post-tsunami initial condition to 
be used in making the future scenarios of the morphological development of the coast. In order to explain the response, the identification of the geomorphic settings and spatial boundaries that govern the morphological development in a certain time scale are, therefore, required as well. Another problem is the lack of information of magnitudes and frequencies of important forcing factors (continuous or intermittent) that are involved in the morphological development processes of different time scales. Pragmatically, the investigation on coastal morphological development in history is a way to understand, and to explain such response and then to consider future scenarios of the development of the tsunamiaffected coast. A lack of understanding of the morphological response as well as of important past forcing factors involved might result in a misleading forecast of the future development of the coast.

\subsection{Location of study area}

On 26 December 2004 at 7:58 hour local time, Nanggroe Aceh Darussalam Province was hit by an earthquake with a magnitude of at least $\mathrm{M}=9.0$ (Stein and Okal, 2005). The epicentre was located in the Indian Ocean, at about $150 \mathrm{~km}$ west of the island of Sumatra (Fig. 1.1). The earthquake generated a tsunami, which led to immense flooding in many coastal areas bordering the Indian Ocean: from Sumatra and Thailand to Sri Lanka, India and even Somalia. The capital city, Banda Aceh, located at the northwest tip of Sumatra Island was worst hit by the tsunami (Fig. 1.1).

Banda Aceh coast is surrounded by the Indian Ocean on the west, the Andaman Sea on the northwest, and the Straits of Malacca on the east. Before the tsunami disaster, the low-lying coastal area of Banda Aceh had been intensively used for human activities. The wetlands and small scale lagoon system and estuaries were used for aquaculture. The low-lying areas were mostly used for housings. The beaches were narrow, nevertheless attracted locals for sea bathing during weekends (e.g. Fig. 1.2a). The beach consisted of fine sand (quartz) and is dissected by regulated inlets (Krueng Aceh River and Floodway Channel), and small natural inlets (e.g. Krueng Cangkoy River and Kuala Gigieng inlet). Manmade structures were installed at some beach stretches (i.e. ferry port, sea wall, beach revetment and groin field). Due to an alternating direction of seasonal wave directions, i.e. from northwest during southwest monsoon and from northeast during northeast monsoon (Meilianda et al., 2006), there are (expected) alternating alongshore sediment transport directions. 


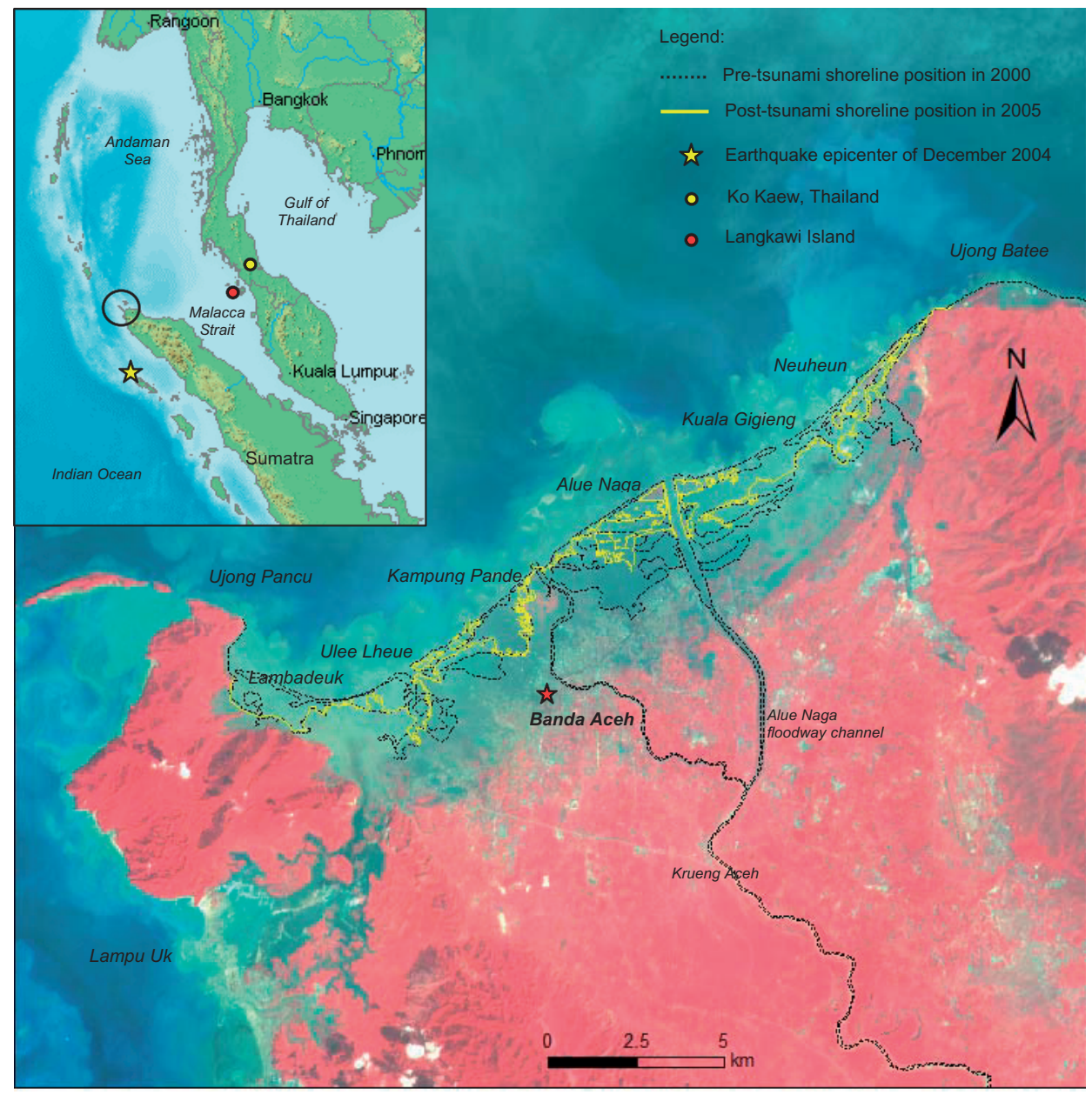

Figure 1.1: Banda Aceh as affected by the inundation during the tsunami event on 26 December 2004 (image SPOT5 of 26 December 2004 at ca. 11.00 local time). The dashed line is the shoreline in 2000 (pre-tsunami) and river channels across the Banda Aceh coastal plain (Inset: Sumatra and Andaman Sea Region). 


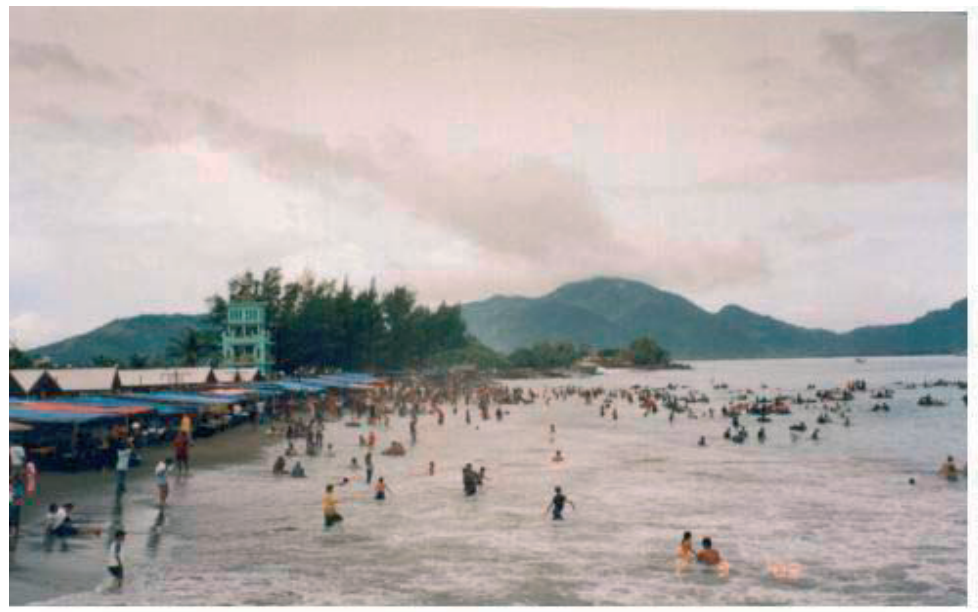

(a)

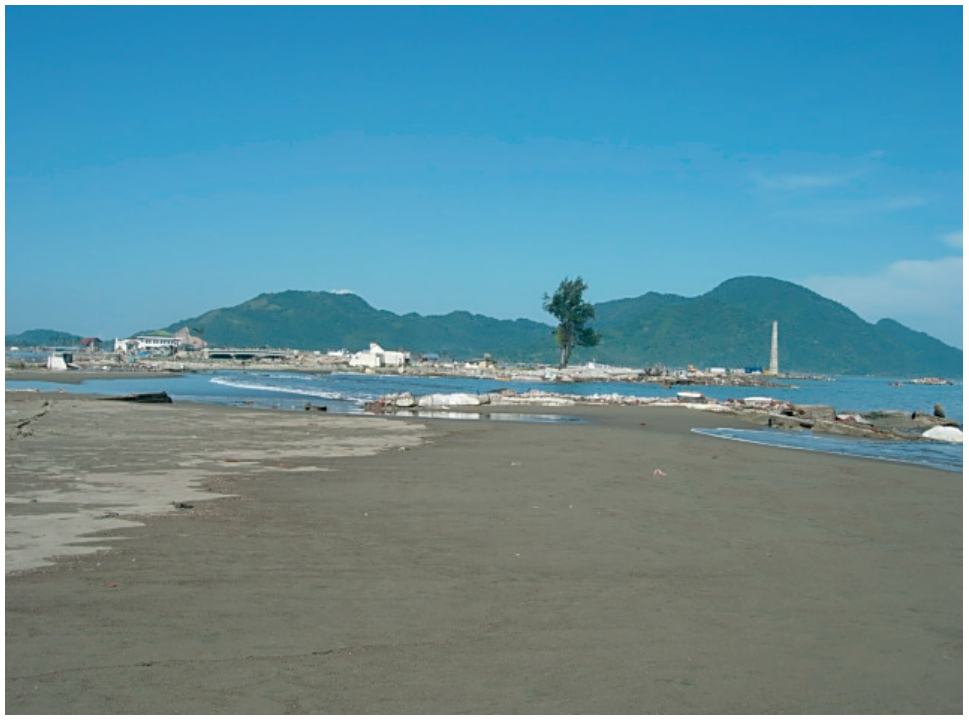

(b)

Figure 1.2: Coast of Banda Aceh. (a) before the tsunami; (b) after the tsunami.

The destructive tsunami waves caused a sudden and immense change in the morphology of the low-lying coast (e.g. Fig. 1.2b and shoreline change in Fig. 1.1). Significant amounts of coastal sediment were scoured, transported and deposited back and forth along the tsunami wave's path, causing immense sediment re- 
distributions over the entire coast (e.g. reported by Narayana, et al. 2007; Umitsu, et al. 2007; Paris, et al. 2007; Jaffe, et al., 2006). Tectonic subsidence is reported to have occurred as a consequence of the earthquakes on 26 December 2004 (e.g. Gibbons and Gelfenbaum, 2005) and also in a subsequent short period after that on 28 March 2005 (e.g. Borrerro, 2005). Despite the devastation due to the earthquake and tsunami, people are likely to return to their original living and business locations close to the coast. This requires proper management of the coastal zone to guarantee the economic livelihood of the coast and safety of the inhabitants against flooding and inundation in the future.

Banda Aceh city $\left(95^{0} \mathrm{~N}, 5^{0} \mathrm{E}\right)$ is located in the triangular coastal plain at the northwest tip of Sumatra Island, Indonesia. It has a $25-\mathrm{km}$ shoreline connecting the Ujong Pancu headland in the southwest to the Ujong Batee headland in the northeast (Fig. 1.1). The shoreline is dissected by parallel lagoon inlets between some of the beach ridges sections. The western part of the shoreline has been interfered by coastal protections such as seawalls, ferry port basin and training jetties at the river mouth. The coast is semi-protected by being located in the back arc region of the Andaman Sea basin, and is influenced by monsoonal climate; southwest monsoon during April to September and northeast monsoons during October to March.

Little was known about the forcing factors involved in the geomorphologic history of the Banda Aceh coastal plain. Such problems explained in section 1.1 also apply to the Banda Aceh coast. As it is so close to the earthquake's epicentre where the tsunami originated, the low-lying Banda Aceh coast is one of the coasts surrounding the Indian Ocean that suffered most from the extensive impact of this event.

\subsection{Research questions and methodologies}

The work in this thesis rested on the notion that older morphological units can be identified to some extent in the present coastal morphology. Each older morphological unit provides a boundary for the more recent units and therefore co-determines the more recent morphological developments. In a short-term, the foreshore develops asymptotically towards a short-term equilibrium. Moreover, the sediment characteristics and availability determine the trend of morphological development of the coast after the intermittent event such as a tsunami and a land subsidence. 
The longer the time scale being considered, the more forcing factors with different frequencies are involved in the coastal morphological development. In a tectonically active region, sudden or rapid land uplift or subsidence resulting from the vertical tectonic movements and the resulting tsunamis are considered as the intermittent forcing factors involved in a hundred-year time scale. At the same time, littoral sediment transport induced by wave actions (continuous forcing factors) plays an important role for the development of the coastal morphology. Shoreline position and orientation are two important parameters to take into account in determining the state of a coast; whether it is an eroding or an accreting coast. As a result of the sudden impact of a tsunami or a land subsidence, the shoreline position and orientation as well as the shoreface morphology may change considerably. These changes lead to a new coastal state and determine the subsequent morphological development.

To achieve the objective, the gap of knowledge about the morphological development of the Banda Aceh coast was bridged in this study by investigating the forcing factors and geomorphic settings of the coast in general, as well as the magnitude and frequency of tsunami and land subsidence occurrences that were involved in shaping the morphology of this specific coastal area in the history. This information is subsequently used to set some scenarios of morphological development in the future. Accordingly, some important questions regarding the response and development of the Banda Aceh coast are formulated as follows.

RQ1: Which morphological units can we distinguish at the Banda Aceh coast and are there differences in their response to the earthquake and tsunami?

a) What are the spatial and temporal scales of the different geomorphic units of the Banda Aceh coastal plain and what was the one in particular that determined the development over the past 100 years?

b) To what extent have the earthquake and tsunami of 26 December 2004 affected this coastal system?

RQ2: How has the coast developed after the tsunami so far (i.e., on a relatively short time scale)?

a) What are the magnitude and spatial distribution of the morphological changes due to the tsunami and subsidence?

b) How did the coast with different geomorphic settings develop in the short time after the tsunami? 
c) What are the opportunities and the pitfalls of using the multi-source data sets to study the morphological development in a less-investigated study location?

RQ3: What kind of variability is expected in the morphological development of the coast in the next century?

a) What are the frequency and magnitude of forcing factors involved in the coastal morphological development related to the earthquake and tsunami?

b) How did the geomorphic settings and the continuous and intermittent forcing factors influence the morphological development of the Banda Aceh coast in the past century?

c) How will the geomorphic settings of the coast since the tsunami of $26^{\text {th }}$ December 2004 and the forcing factors in different scenarios influence the morphological development in the next century?

Based on the aforementioned formulated problems and research questions, it is clear that the present study took an explorative methodology and engaged the time-scale-related issues on the coastal morphological processes related to the earthquakes and the related tsunami and land subsidence. The flow of the research in this thesis was driven by a wide span of geomorphological interpretation, field observations, spatial data analysis from satellite images, topographic and bathymetric maps, analysis of forcing factors magnitudes and frequencies as well as sediment budget analysis of the littoral transport. The integration of various approaches provided essential knowledge about the study area by analysing the geomorphic settings and the forcing factors involved in the morphological development. The rationale of this is that it is essential to understand the geomorphic settings of a coast before attempting to make a scenario of the future development of the coast (Riggs et al., 1995). The results provided the information needed to develop some scenarios to forecast the future coastal development over the time scale of interest, which is in a century.

The variability of coastal morphological developments was also investigated on shorter and longer time scales. In this way, the spatial boundaries related to certain morphological processes in time can be identified with respect to the notion that each older morphological unit provides a boundary for more recent units and therefore co-determines more recent morphological developments. At the same time, forcing factors related to this variability can also be identified. Another important issue is that morphological changes due to the earthquake and 
tsunami occur on a large spatial scale, but on a very short time scale. Therefore, the response due to and development after such a sudden change in morphology presumably would be different compared to those, for instance, affected by continuous sea-level rise. Figure 1.3 displays the timeline of the morphological development studied in this thesis.

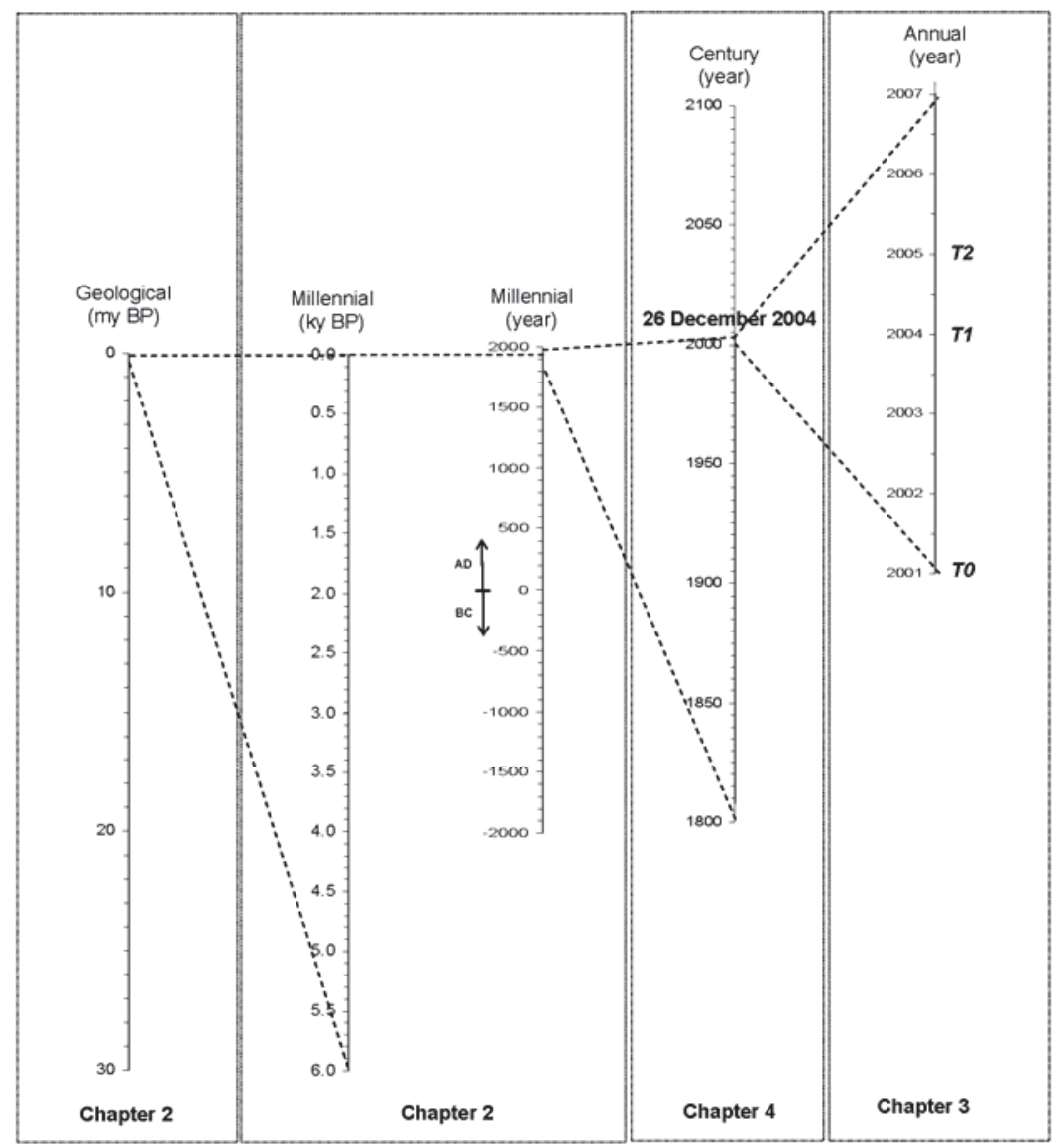

Figure 1.3: Timeline of the coastal morphological development in this study encompassing geological, millennial and engineering time scales.

In this study we used the emphasize the rate of shoreline position changes and orientations as the important parameters to quantitatively describe the morphological development in the future given the recurrence of tsunami and/or land subsidence, and their influences on the morphological development trend of the coast. 
Finally, the present study should contribute to the state of the art of knowledge on the morphological development of a tsunami-affected coast with regard to coastal management issues for such a less investigated area in particular, and also with regard to insight into the coastal morphological response and development on a tsunami-affected coastal zone in a broader context.

\subsection{Thesis outline}

The thesis consists of three major parts contained in the next three chapters.

Chapter 2: Geomorphological outline of Banda Aceh coast and the impact of the tsunami of 26 December 2004

In this chapter the morphology of Banda Aceh coast and how it was developed in the past encompassing geological to decadal time scale development was investigated. It gives detail information about the geomorphic settings of the coast.

Chapter 3: Short-term morphological responses and developments of the Banda Aceh coast after the tsunami on 26 December 2004

In this chapter the impact of the tsunami and land subsidence to the foreshore zone was studied. A short-term development of the coast after the impact was also observed and compared with another tsunami-affected coast with different geomorphic settings.

Chapter 4: Scenarios for future development of a sand-poor coast subjected to tectonic and tsunami

In this chapter some scenarios for future development of Banda Aceh coast for the next century were analyzed. This was done by using information on the geomorphic settings that has been characterized and also the new state of the coastal morphology after the tsunami described in Chapter 2 and Chapter 3.

\section{Chapter 5: Discussion}

This chapter contains the discussion and synthesis of morphological developments of the coast in the past, present and future and also issues on uncertainties.

Chapter 6: Conclusion and recommendations

The conclusion provides the answers of the research questions posted in Chapter 1 and finally the thesis is closed with some recommendations. 


\title{
Chapter 2
}

\section{Geomorphological outline of Banda Aceh coast and the impact of the tsunami of 26 December 2004}

\begin{abstract}
The objective of the present study is to explain the response of the coastal morphology due to the tsunami of December 2004 by characterizing the underlying geomorphic settings that control the coastal morphological development history of Banda Aceh coastal plain. The integration of field observations, satellite images, old topographic maps and nautical charts to provide the interpretations in tectonics, sea-level fluctuations, geomorphology and archaeology of this region was conducted and to be used as a proxy for non-existing detailed in-situ data. The results were the identification of the forcing factors involved in the development of the coastal morphology in different time-scales back in history that is from geological to decadal time-scales.

Banda Aceh coast is a sand-poor environment contains only a thin layer of loose sand on top of a consolidated Holocene prograding delta. The earthquake and tsunami of December 2004 also affected the morphological units that have been established in the Holocene period (e.g. the breached old beach ridges and the cropped-out older shoreface deposits). The seawater inundated to the coastal plain as far inland as the shoreline position of 0.6 ky BP, during which a similar magnitude of tsunami confirmed to have occurred. The responses of shoreface profiles to the tsunami waves were different from one profile to another due to different geomorphic settings.

In addition, it is interesting to find the coincidences of changing phase between marine regression and transgression inferred from the sea-level fluctuation and specifically identified morphological units on the Banda Aceh plain suggesting the pulses of abrupt sea-level changes occurred every 500 to 600 years during the long-term sea-level fall of the Holocene (from ca. $5.5 \mathrm{ky}$ BP until present), with an interval of two thousand years in between pulses.

This study illustrates that such huge tsunami event occurred only in a very short time-scale, but it led to changes in morphology comparable to changes that normally occur on a time-scale of century to millennia. The eroded sediments made its contribution as a new deposited layer that will be imprinted in the geological history of this coast.
\end{abstract}




\subsection{Introduction}

Banda Aceh, located on the northwest tip of Sumatra Island, Indonesia, was hit by the powerful earthquake on 26 December 2004. The subsequent tsunami waves triggered by the earthquake brought about massive seawater inundation to the lowlying coastal area as far as 4 to $5 \mathrm{~km}$ inland, leading to high casualties and massive destruction.

Despite a worldwide effort on rehabilitating and reconstructing the coastal area, a lack of comprehensive knowledge about the characteristics of the coastal area remains a major concern from an engineering point of view. This hampers the effort of realistically forecasting the future development of the coast, and thus, any decisions on engineering measures may be made on a weak base. The main source of the problem is that little was known about the geomorphological history of this tectonically active region. In particular, only very limited research has been done on the dynamics of the coast in front of this densely populated area preceding the tsunami of December 2004.

The objective of the present study is to determine the characteristics of the underlying morphological units of the coastal system that control the coastal morphological development of the Banda Aceh coast. The work in this study rests on the notion that older morphological units can be identified to some extent in the present coastal morphology. Each older morphological unit provides a boundary for the more recent units and therefore co-determines more recent morphological developments.

We investigated the morphological development in geological, millennial and engineering time-scales (Fig. 2.1). This was motivated by our preliminary superficial observations of the coastal morphology of Banda Aceh (e.g. from the field and remote sensing data) which shows a complex topography, including the coastal bathymetry. They suggest that a combination of tectonic activities, alluvial development, and sea-level fluctuations may have shaped the morphology during a long-term development history. The chronology of morphological processes involved in Banda Aceh's history, however, remains unclear. Therefore, in this study, we identified the pre-existing morphological units and placed them in a chronological perspective.

Since the physical data, such as sediment samples and carbon-dating of insitu material, was lacking, we combined our geomorphological interpretation of the field and remote sensing data with several studies in such a way they corroborate each other to fill in the gaps of knowledge about the morphological development of Banda Aceh coast. We carried out morphological interpretations of spatial data 
from sources such as historical topographic maps, nautical and bathymetric charts and satellite images, covering the period from 1893 to 2006. We used scientific literature providing descriptions of general tectonics, geomorphology and climate to chronological analysis of the morphological development of the coast.

This information determines the spatial boundaries needed, for instance, to investigate the geomorphological extent of the impact due to the earthquake and tsunami of December 2004 and to forecast the future development of the coastal morphology on an engineering time-scale, which will be the next steps of the present study. More specifically, the present study aims to resolve the following questions:

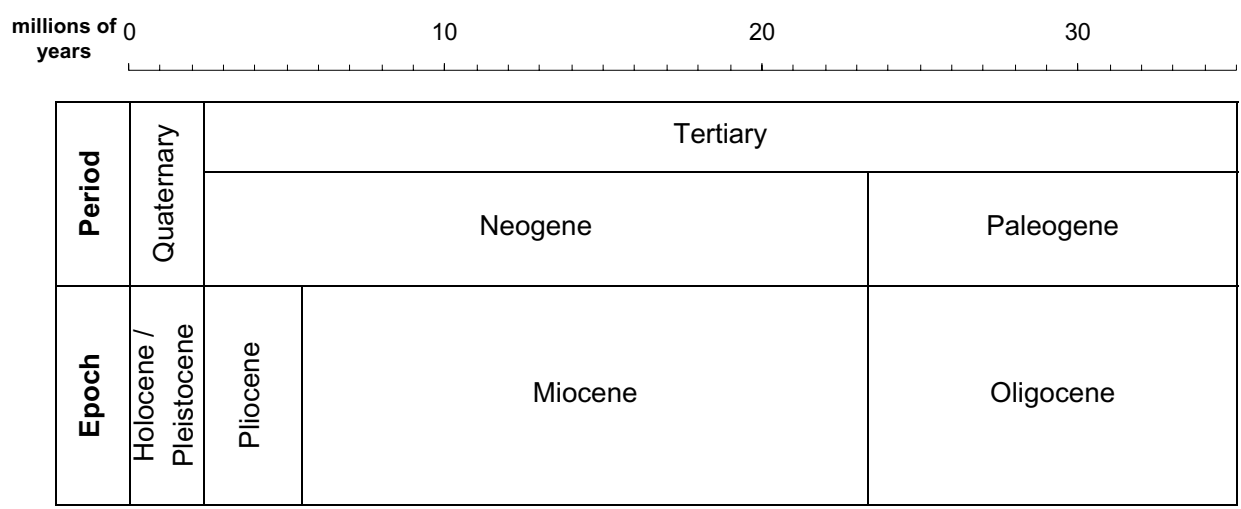

Figure 2.1: Geological time-scale to guide the timeline of morphological developments throughout this study.

RQ1: Which morphological units can we distinguish at the Banda Aceh coast and how do they respond to the earthquake and tsunami?

a) What are the spatial and temporal scales of the different geomorphic units of the Banda Aceh coastal plain and what was the one in particular that determined the development over the past 100 years?

b) To what extent have the earthquake and tsunami of 26 December 2004 affected this coastal system?

The outline of the paper is as follows. Section 2.2 describes a general overview of the study site and the data sources. The geomorphological interpretations are described in the subsequent sections. They provide descriptions 
of the identification of morphological units, the processes involved and the corresponding periods of their occurrence. The reader may either follow the chronology or focus only on a specific time-scale of interest. For convenience, the descriptions are divided into three time-scales: i) geological time-scale (section 2.3), ii) millennial to centennial time-scales (section 2.4), and iii) (engineering (decadal) time-scale over the past century (subsection 2.5). A cascade model which schematizes the chronology of the overall morphological history of the Banda Aceh coast is eventually presented and discussed in section 2.6, in which the implications of the impact due to the earthquake and tsunami on the coastal morphology are also discussed. Some concluding remarks and recommendations are given in section 2.7 .

\subsection{Study site and data sets}

\subsubsection{Study site}

Banda Aceh is located at the centre of the 25-km coastline of the northwestern tip of Sumatra Island, from the Ujong Pancu in the southwest to the Ujong Batee in the northeast (Fig. 1.1). The coastal plain has elevations from $+0.5 \mathrm{~m}$ to $+11 \mathrm{~m}$ relative to present sea-level and occupies 125 square $\mathrm{km}$ of the northwest valley of the Barisan mountain range, which is the backbone of Sumatra Island. Krueng Aceh River is the main river crossing this low-lying coastal plain. In the 1990s, the middle reach of the river was bifurcated by a floodway channel, as a means to divert the surplus discharge of the river which caused annual flooding of the city. The coastline is dissected by parallel lagoon inlets between some of the beach ridges sections.

\subsubsection{Methods and data sources}

This study interpreted the geomorphology of the Banda Aceh coast from various types of maps and imagery covering the past century (Table 2.1) and from literature covering the geological and geomorphological evolution of the surrounding region. The topics of interest and the main literature sources used in this study are listed in Table 2.2.

All maps, images and charts were geo-referenced to a master map (i.e. ortho-rectified aerial photo of 2005) which was processed in ArcGIS. The nautical charts and bathymetric data were transformed into Digital Elevation Models (DEMs) using Triangulation Irregular Network (TIN) which was done in ArcView. 
The topographic map with a $0.5-\mathrm{m}$ contour interval in Table 2.1 was derived using a photogrammetric technique from the master map. This topographic map acquired in June 2005 and was also converted into a DEM.

Table 2.1: Spatio-temporal data sources of Banda Aceh coast

\begin{tabular}{cccc}
\hline Data source & Date / Time & Spatial scale /resolution & source \\
\hline Nautical charts & 1893 & $1: 150000$ & KITLV Amsterdam \\
\cline { 2 - 4 } & 1924 & $1: 100000$ & KITLV Amsterdam \\
\hline Topographic maps & 1898 & $1: 20000$ & KITLV Amsterdam \\
\cline { 2 - 4 } & 1924 & $1: 50000$ & KITLV Amsterdam \\
\hline Satellite images & $05 / 06 / 1967$ & $2.0 \mathrm{~m}$ pixel resolution & KeyHole-7 / USGS \\
\cline { 2 - 4 } & $23 / 03 / 1989$ & $30 \mathrm{~m}$ pixel resolution & Landsat TM+ / ITC \\
\cline { 2 - 4 } & $08 / 03 / 2000$ & $30 \mathrm{~m}$ pixel resolution & Landsat ETM+7 / \\
\cline { 2 - 4 } & & & ITC \\
\hline Topographic map & June 2003 & 0.5 m contour interval & NORAD survey / \\
& & & JICA / SIM Centre - \\
& & BRR NAD \\
\hline Bathymetric chart & January 2006 & Resampled to 0.5 m pixel & SDC - BRR NAD \\
& & resolution & \\
\hline
\end{tabular}

Table 2.2: Overview main sources of related studies.

\begin{tabular}{lll}
\hline \multicolumn{1}{c}{ Topic } & \multicolumn{1}{c}{ Main literature sources } \\
\hline Tectonics Andaman Sea region & Curray (2005) \\
& Sieh And Natawidjaja (2000) \\
\hline $\begin{array}{l}\text { Recent history of land subsidence in Banda Aceh } \\
\text { region }\end{array}$ & McKinnon (1988) \\
\hline $\begin{array}{l}\text { Tertiary and Quaternary geologic evolution of the } \\
\text { Sumatra region }\end{array}$ & Bemmelen (1949) \\
& & Verstappen (1973,2000) \\
& Montagne (1950) \\
\hline Post-glacial, Holocene sea-level & fluctuations & Baker, et al. (2001) \\
inSoutheast Asia and Australia & & Hesp, et al. (1998) \\
& & Sinsakul, et al. (1990) \\
& Tjia and Fujii (1989) \\
& Tjia (1992) \\
& Woodroffe and Horton (2005) \\
\hline Coastal morphology / landform & Bird (2000) \\
& Schuum, et al. (1987) \\
\hline
\end{tabular}


The time units used in this study are 'my BP', 'ky BP' and 'y BP', corresponding to 'million years before present', 'thousand years before present' and 'years before present', respectively. Different articles used different indications of elevation, such as 'present sea-level', 'mean sea-level', or 'mean low water level', but all of these elevation references actually used the mean low water level as datum reference (Woodroffe and Horton, 2005). In this study, the tidal range is not of significant influence (ca. $1.5 \mathrm{~m}$ range) on the overall interpretations and the 'present sea-level' (PSL from here on) is, therefore, conveniently used as reference elevation throughout this paper.

\subsection{Development on the geological time-scale}

The subsequent sections are dedicated to describe the development of the coastal area on the northern tip of Sumatra Island that provides the spatial boundaries of the present coastal morphology of Banda Aceh. Geomorphological interpretation is achieved by corroborating multi-source data sets and literature to describe the morphological development in the geological history. This is used as a proxy to the non-exist data (e.g. sediment layer stratification) which provides the explanation of the morphological units that can be identified in the modern morphology of Banda Aceh. The geological timescale in Figure 2.1 is of use for the chronological guide, and the development of each morphological units associated with certain forcing factors is chronologically synthesized in a cascade model in Figure 2.8. Satellite images of Landsat ETM+7 and RSTM acquired in 2000 and 2003, respectively, were used to trace the morphological units associated with the information given from different source of geomorphology and tectonic literatures.

\subsubsection{Oligocene to Early Miocene (32 to 23 my BP)}

Tectonic activities in this period triggered the spreading of the Sagaing Fault system (Fig. 2.2). The spreading played an important role in creating the boundary of Banda Aceh coastal plain which facing the solitary Andaman Sea basin on the north, and bounded by Barisan mountain range on the south and west.

Figure 2.2 shows the convergence process of the subduction zone between the Indo-Australian and Southeast Asian plates interpreted by Curray (2005). The convergence began in the Eocene. Throughout the early Oligocene, a clockwise rotation of the northern part of the subduction zone took place. The subduction 
of the Indo-Australian plate was moving northward which resulted in an acute angle with the subduction zone along the western Sumatra and the fore-arc Andaman-Nicobar Islands. As the movement direction of the subducting IndoAustralian plate (due north) and the actual subduction zone became more and more acute (Fig 2.2), lateral displacement also occurred along the corresponding subduction zone, which caused complex fault spreading and fault deformation structures in the Andaman Sea region.

In this period, the Sagaing Fault was connected to the West Andaman Fault (i.e. WAF in Fig. 2.2a), which is located between the active subduction zone on the west and Sumatra on the east (Curray, 2005). The lateral displacement along this fault line triggered the major spreading of the Sagaing Fault between Burma (Myanmar) in the north and Sumatra in the south (Fig. 2.2a). This brought about rapid subsidence of which the early stage of the Andaman Basin was created along with the emergence of Sumatra and small fore-arc islands.

\subsubsection{Early Miocene to Middle Miocene (23 to 15 my BP)}

The Barisan mountain range started to develop in the Early Miocene. Van Bemmelen (1949) suggested that epeirogenesis - slow vertical tectonic movements - may have been the important control on terrestrial and marine morphological processes affecting the Banda Aceh valley during the Miocene. According to Curray (2005), the formation of this mountain range was apparently associated with the currently active West Andaman Fault (WAF) system (Fig. 2.2a and 2.2b). This was followed by block faulting and volcanic activity (i.e. probably associated with the eruption of the Alcock and Sewell Seamounts beneath the Andaman Sea) towards the middle Miocene.

The sediment layers developed from this period onwards are considered important in this study because they describe the morphological unit/layer of the base-level of the modern coastal morphology of Banda Aceh. Verstappen (1973) described the sediment characteristics associated with this period of development. As the subsidence of the Andaman Basin slowed towards the end of early Miocene, the basin was filled in with marine or brackish water sediments. This is in accordance with Bemmelen (1949) who stated that during this period the central portion of the basin, going south towards the northern tip of Sumatra, consisted of hydrocarbon-rich Tertiary sediments. The marine transgression as the result of the subsidence began earlier in this zone compared with other regions in Sumatra and took place over a long time, and probably continued towards the late Pliocene. It 
led to the base-levelling in the Banda Aceh valley as far inland as Seulimum and as far seaward as the bathymetric depth of $-250 \mathrm{~m}$ (Fig. 2.3a). At present, this $250-\mathrm{m}$ depth contour forms the submerged shoreline which is associated with the innershelf's slope break in front of the Banda Aceh coast. Van Bemmelen (1949) considered the offshore in front of Banda Aceh as a median graben (valley), which can be traced from the Bengalen Passage to the west of Weh Island (Fig. 2.3a).

Furthermore, the age and tectonic history of the Andaman basin close to the northwest tip of Sumatra (Banda Aceh) provided by Neprochnov (1964) supports the abovementioned development of the Andaman Basin chronology. He mentioned that the age of the inception of sedimentation in this particular region is about $12 \mathrm{my}$, and the horizon of $500 \mathrm{~m}$ below the sediment-water interface is about 3.7 my old. This may suggest that the sediment of the deep water in this region is of Neogene/Tertiary age (Fig. 2.1).

\subsubsection{Middle Miocene to Late Pliocene ( $15 \mathrm{my}$ BP to $3 \mathrm{my}$ BP)}

Umbgrove (1948) described that the folding which produced the structures of the Barisan mountain range of Sumatra as well as Simeulue, Nias, Siberut and Mentawai Island in Figure 1.1 occurred during the middle Miocene. This process may be related to the ongoing epeirogenesis of the same period observed by Van Bemmelen (1949) which led to the strata in the nearby Barisan mountain range which seems to be affected by a normal faulting. These old marine strata of the conformable sandstone and conglomerate zone are situated on the top of the Border Clay. Then the sedimentation ends in this marginal area, which indicates an uplift of the central Barisan area at that time. This uplift was accompanied by volcanic activity as appeared from the intercalations of eruptive deposits from the Seulawah Mount (Fig. 2.3a and 2.4b).

This process explains the characteristics of marine deposits found on a high elevation (relative to the present sea-level) by Montagne (1950) at the southern border of the Banda Aceh valley. Area near Seulimum, Great Aceh (Fig. 2.4) was indicated as the 'old high terraces'. The deposits of these old high terraces were formed during the Tertiary period without further specified dating; the terrace elevation ranged from 65 to $70 \mathrm{~m}$ high above the present sea-level. From the two sources of geomorphological interpretation we argue that this old terraces was developed during this period. In addition, no important subsidence has occurred since early Miocene (Verstappen, 1973), which suggests that the base-level of the Banda Aceh plain (the valley) was vastly developed during this period. 


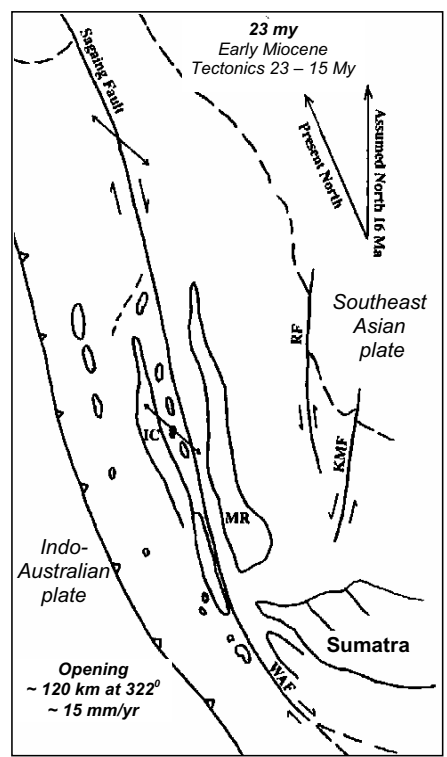

(a)

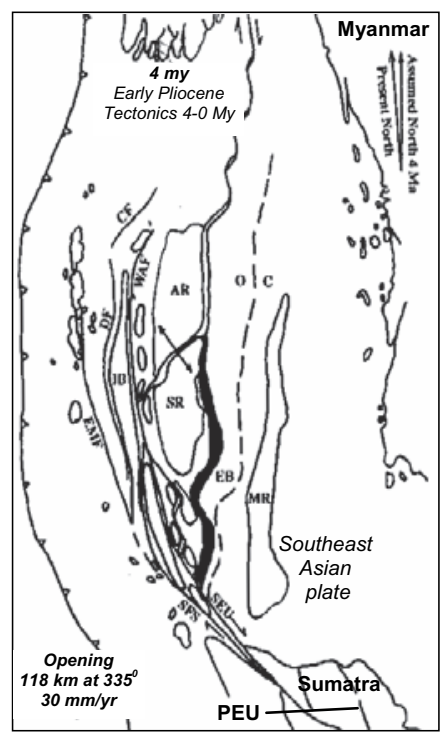

(c)

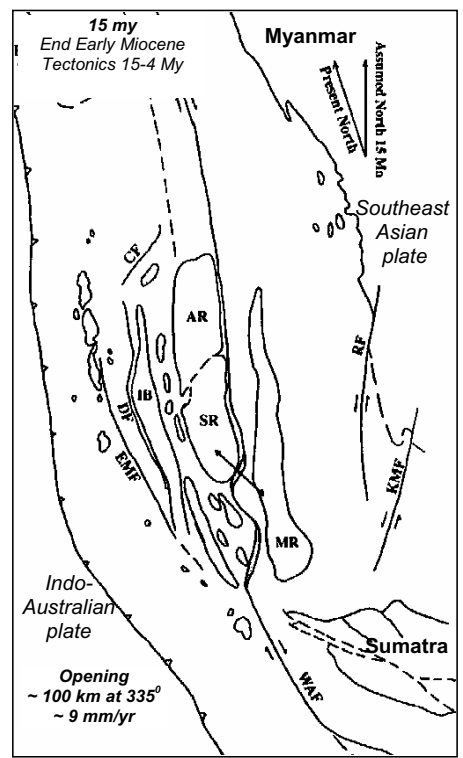

(b)

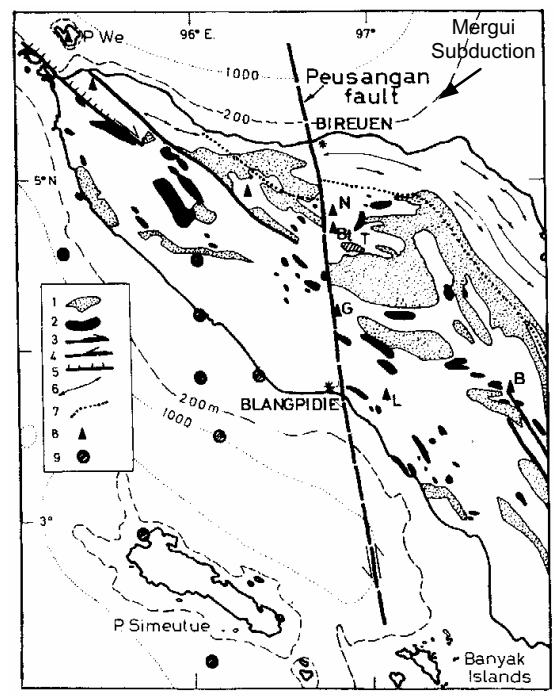

(d)

Figure 2.2: $(\mathrm{a}, \mathrm{b}, \mathrm{c})$ Simulation of the clockwise rotation of the subduction zone at the west coast of Sumatra by Curray (2005), leading to the spreading of the Andaman Sea and the emergence of Sumatra Island (image courtesy: Curray, 2005); (d) Tectonic faults at the northtip of Sumatra Island (image courtersy: Tjia, 1977). 


\subsubsection{Late Pliocene to early Pleistocene ( $3 \mathrm{my}-1.7 \mathrm{my})$}

Following the epeirogenesis process towards the late Pliocene, orogenesis - rapid vertical tectonic movements - occurred subsequently. Verstappen (1973) reported that a final period of orogenesis on the north tip of Sumatra took place in the PlioPleistocene. Block-faulting and rift formation in the Barisan range continued with renewed force. The crest of the fold of the Barisan zone was longitudinally broken up by the so-called Semangko fault zone, which comprises two major strike-slip fault zones: the Sumatra Fault System (SFS) and the Seulimum Fault System (SEU) (Fig. 2.2c and Fig. 2.3a). This is in agreement with the age of the activation of the SFS and the SEU estimated by Sieh and Natawidjaja (2000), which are 4 my BP and 2 my BP, respectively. In addition to the creation of these transcurrent zones, lateral faulting across a transcurrent zone south of Banda Aceh was also activated during this period, namely the Peusangan Fault (PEU in Fig. 2.2d; Verstappen, 2000; Tjia, 1977) or Samalanga-Sipokok Fault (Curray, 2005). The strike-slip movement between northeast Sumatra and southeast Seulimum caused a remarkable offset in the middle of the PEU, which shows the dynamics of the tectonic activity in this region during this period. This may also have resulted in the offset position of the Ujong Pancu, a headland which juts out northwestward due to the strike-slip movements of the SFS. The wedge between the SFS and SEU forms a graben (valley) in which the Banda Aceh coastal plain is situated.

The Barisan, Nasi, Breueh and Nicobar-Andaman fore-arc zone on the western side reached its mature uplift. The subaqueous part of the arc created a submarine sill separating the Indian Ocean from the back-arc basin of the Andaman Sea. Presumably, this may also have been associated with the increase of the spreading rate of the Sagaing fault; from $9 \mathrm{~mm} / \mathrm{yr}$ in the early Miocene to 30 $\mathrm{mm} / \mathrm{yr}$ in early Pliocene, as reported by Curray (2005).

On the northeastern side, the subduction of the small Mergui plate beneath the northern tip of Sumatra probably started as well (Fig. 2.2d). Of the studies we used, a study by Verstappen (2000) was the only one that indicated this subduction zone, although the time of the activation was not mentioned. Nevertheless, providing that the final orogenesis occurred during this period, it might be reasonable to assume that the activation of this small subduction zone occurred in conjunction with this orogenesis. This led to the uplifted northeastern tip of Sumatra at Ujong Batee and Weh Island, and also the depressed zone on the southwestern portion of the coastal plain associated with the normal faulting of SFS. 


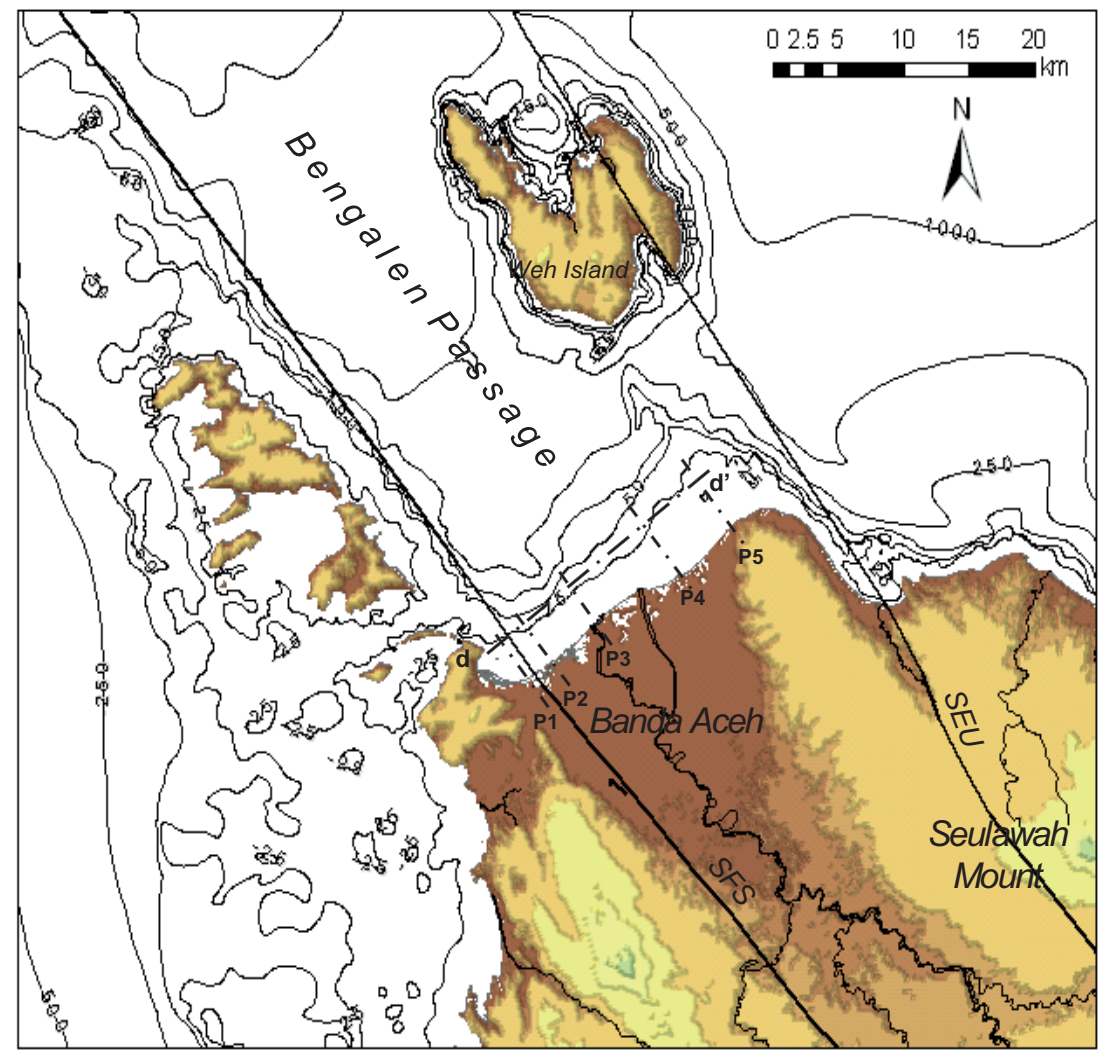

(a)

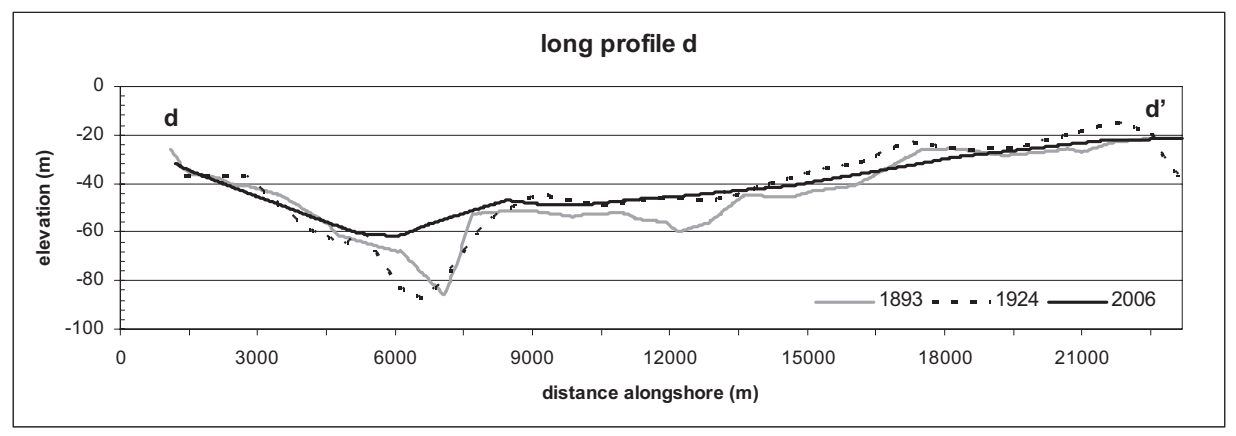

(b)

Figure 2.3: (a) Bathymetric map of northwest tip of Sumatra; (b) Profiles of the years 1893, 1924 and 2006, with a marine canyon. 


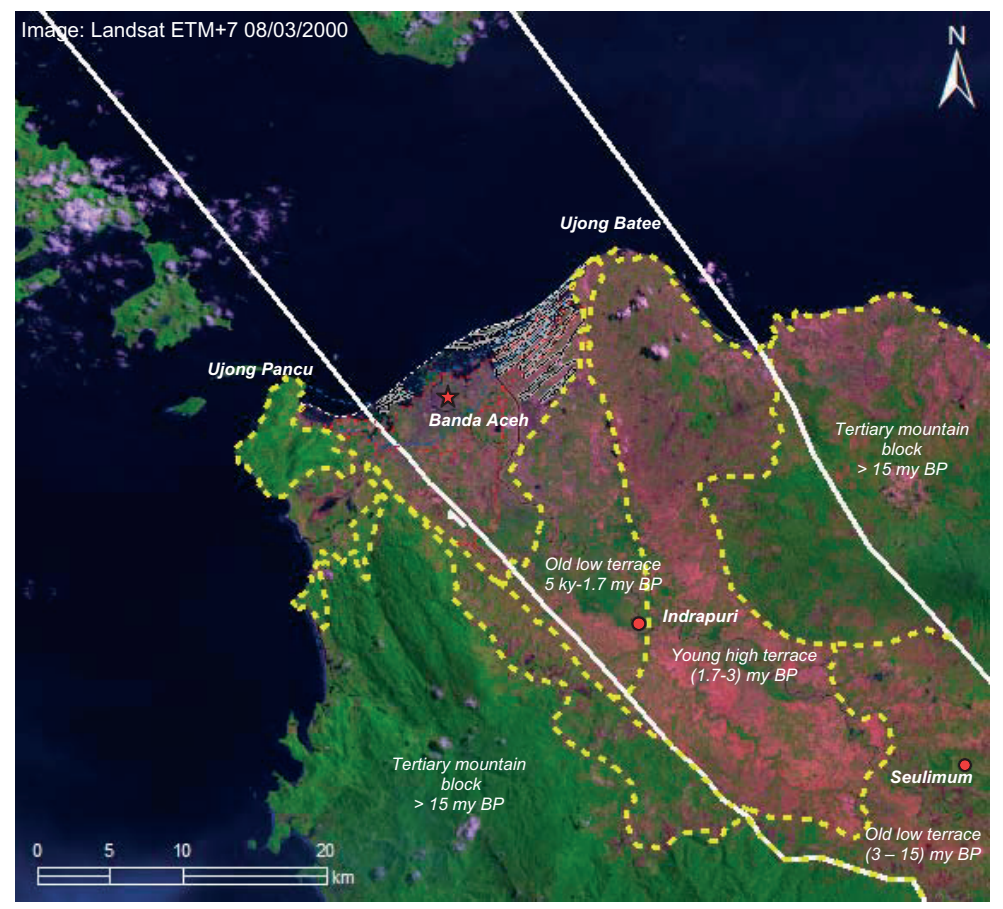

(a)

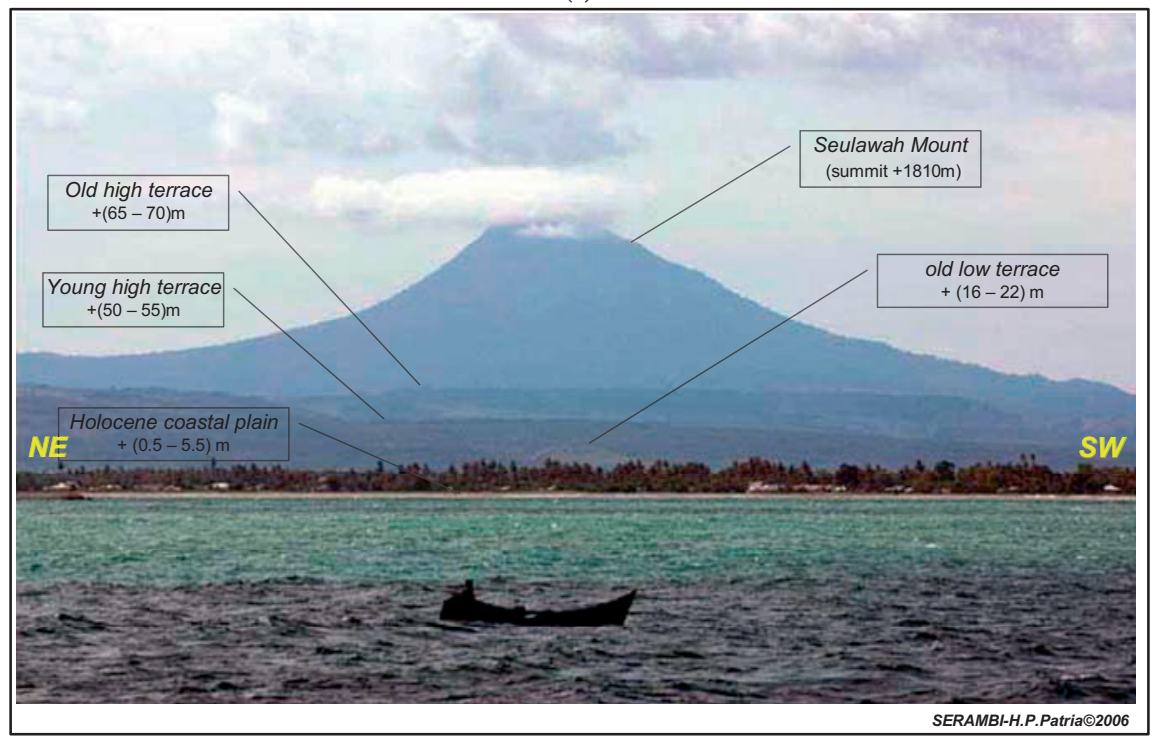

(b)

Figure 2.4: (a) Subaerial boundaries of the Banda Aceh coastal plain; (b) Waterfront view of the Banda Aceh coastal plain revealing the volcano of Seulawah and multiple terraces. Photograph was taken from Ujong Pancu headland facing eastward. 
The 'young high terrace' in Figure 2.4 was adapted from the geomorphology map in Montagne (1950) which covered only the area from Seulimum to Indrapuri (Fig. 2.4.a). We extended this boundary towards the Ujong Batee by tracing the similar morphology and elevation observed in the satellite image of RSTM in 2003 (Fig. 2.3a) and Landsat ETM+7 in 2000 (Fig. 2.4a). This morphological unit is highly likely associated with this tilting process which can be seen from the waterfront of Banda Aceh (Fig. 2.4b). Seaward evidence can be identified as well in the alongshore bathymetric profile in Figure 2.3b. It clearly shows the trace of a submarine valley at the southwestern part of the profile, which is associated with the SFS. This clearly suggests that the Banda Aceh coastal plain did develop on top of a westsouthwestward tilted Pleistocene structure.

As was mentioned in section 2.3.2, the base-levelling process that started in the Miocene continued throughout the Pliocene. This process, apparently, was disrupted by a sequence of tectonic movements. The young high terraces are the landward boundary of the Krueng Aceh channels between Seulimum and Indrapuri in Great Aceh (Fig. 2.4a and 2.4b). Their elevation was +50 to $+55 \mathrm{~m}$ relative to the present sea-level, or 15 to $25 \mathrm{~m}$ lower than the old high terraces. This morphological unit is commonly observed in Sumatra and Java (Verstappen, 2000). The age of the deposits in the young high terraces is Neogene, and some coral traces are present (Montagne, 1950). This marine influence suggests that the terraces were uplifted at some point after which a marine transgression filling in the valley.

\subsubsection{Pleistocene - mid Holocene (1.7 my - 5.5 ky BP)}

The subsequent morphological boundary towards the Holocene coastal plain of Banda Aceh consists of low terraces. Montagne (1950) indicated that the low terraces were of Quaternary and consisted of old and young low terraces. The old low terraces were at +16 to $+22 \mathrm{~m}$ and the young ones were at +7 to $+11 \mathrm{~m}$ from the present sea-level, or a difference of 9 to $11 \mathrm{~m}$ between them, which is actually associated with the hinterland of the Banda Aceh coast (Fig. 2.4a).

From this period to the Holocene, the morphological development was very much influenced by the lowering sea-level of the Last Glacial Maximum (LGM). This occurred particularly in this period (about $30 \mathrm{ky} \mathrm{BP}$ ), when the earth's crust deformed downward burdened by continental ice sheets, forcing sublithospheric flow away from the centres of load and the oceanic geoids migrated from lower to higher latitudes in a process called equatorial ocean syphoning (Mitrovica and Peltier, 
1991). Geyh et al. (1979) were the first to carbon-date the sea-level indicator from the late Pleistocene to the Holocene in the Strait of Malacca. The data indicated the approximate sea-level towards the Middle Holocene. The lowest position of sea-level was associated with the LGM between the late Pleistocene and midHolocene. The sea-level was lowered eustatically to at least 40 to $60 \mathrm{~m}$ below the present sea-level between 36 and $10 \mathrm{ky} \mathrm{BP.}$

The dramatic climate change seems to be responsible for the sea-level changes. According to Verstappen (1980), during the Pleistocene periods of low sea-level the climatic conditions in Southeast Asia were drier than present. This was related to the fact that both the Southeast Asian plate and the Indo-Australian plate emerged during the glacial as a result of the lower sea-level. The InterTropical Convergence Zone (ITCZ) was located more southerly. This means that southern Indonesia was characterized by high precipitation, while the northern part of Indonesia (e.g. Sumatra) had a drier climate.

In Sumatra, the drier climate, particularly in lowland areas, may have caused increases in seasonality and daily temperature range. These factors produced drought stress in the vegetation. The effect on the river regime was pronounced, with rock disintegration leading to debris caused by flash discharges and gradually increasing the thickness of the valley fill. The young low terraces defined by Montagne (1950) are associated with these processes. This can be explained by the formation of the alluvial plain which started at Indrapuri and continues downstream. The course of the Krueng Aceh along this alluvial plain was further incised during the low sea-levels of the Pleistocene. On the coast, when the sea reached its lowest level at the LGM (ca. $30 \mathrm{ky} \mathrm{BP)} \mathrm{the} \mathrm{Pleistocene} \mathrm{sandy} \mathrm{deposits}$ were emerged and scattered across the sea floor profile offshore.

\subsection{Morphological development in millennial to centennial time-scale}

In this period, the entire coastal plain of Banda Aceh was developed providing complex dynamics of sea-level fluctuations and tectonic activities. The development of the coastal plain is described in this section in terms of shoreline position changes in the past millennia towards the present shoreline position. We analyse the morphological development of Banda Aceh coast by utilizing the curve of sea-level fluctuation by Tjia and Fujii (1989) in Figure 2.5, the DEM of the coastal plain derived from a detailed topographic map of June 2005, and the satellite image of Landsat ETM+7 of 2000 (Table 2.1). 
The sea-level fluctuation indicated by Tjia and Fujii (1989) was corroborated with the elevations from the DEM of morphological units identified in the satellite image of Banda Aceh. In this way, the shorelines associated with different phase of transgression and regression of sea-level during the Holocene can be extracted. Important forcing factors involved during the Holocene period are firstly described to understand the interplaying processes leading to the morphological development.

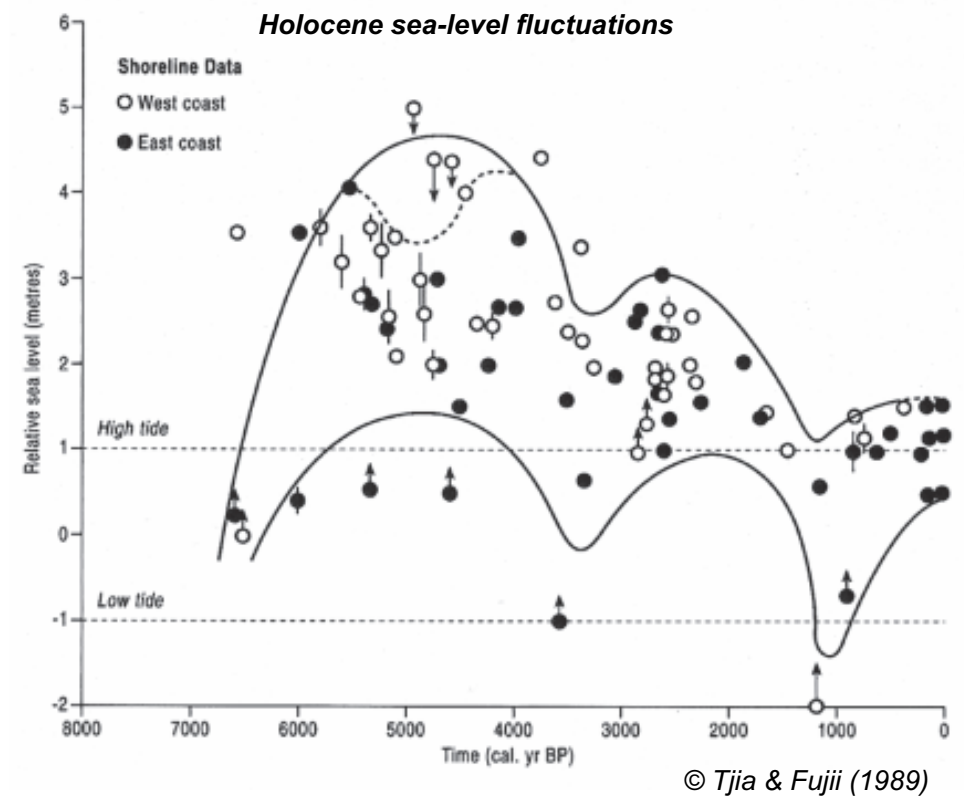

Figure 2.5: (a) Holocene sea-level fluctuations suggested by Tjia and Fujii (1989). The low tide line is the datum reference (i.e. present sea-level) of the present study. Sample locations at Langkawi Island, Malaysia and by Sinsakul (1990) at Ko Kaew, Thailand can be seen in the inset of Figure 1.1. Image courtesy: Woodroffe and Horton (2005).

\subsubsection{Sea level during the Holocene}

As previously described, Sumatra is located in one of the world's most tectonically active regions. Nevertheless, during the post-glacial period of the Holocene, neotectonic movements were less important compared to the influence of the sea-level fluctuations due to the deglaciations. Sieh and Natawidjaja (2000) suggested that the SFS has not been active for the past hundred thousand years. Therefore, it 
seems likely that tectonic activities during the Holocene were much less influential than in the Miocene to Pleistocene as described in the preceding subsections. Sealevel change thus became a dominant factor that enables the interpretation of the coastal evolution of the Banda Aceh coastal plain on the tip of Sumatra, based on the study of Holocene sea-level fluctuations in its neighbouring regions.

The morphological development in Holocene epoch in general was influenced by global ice melting which produced a combined effect of glacial-enstasy (deglaciation in the last glacial period), tectono-eustasy (i.e. due to the earth's crustal movements), and geoidal-eustasy (i.e. the global oceanic water distribution) to the sea-level fluctuation (see further explanation in Woodroffe and Horton, 2005). During the deglaciation following this LGM, Southeast Asia which lays close to the current zero geoid may have experienced a drop in sea-level, while at the same time, for example, the east coast of Argentina experiences sea-level rises. This equatorial ocean syphoning are only seen in the late Holocene (Woodroffe and McLean, 1990).

Banda Aceh, at the northwest tip of Sumatra is located at low latitudes as well $\left(5^{0} \mathrm{~N}\right)$, hence, a sea-level fall was likely also experienced in this region. The sea-level raised from $-13 \mathrm{~m}$ in $8.0 \mathrm{ky} \mathrm{BP}$ to about $+5 \mathrm{~m}$ around $5.5 \mathrm{ky} \mathrm{BP}$ and then declined towards the present level (Geyh et al., 1979). Tjia (1992) suggested slightly higher rates, namely between $15 \mathrm{~mm}$ and $6 \mathrm{~mm}$ annually, to reach its maximum mid-Holocene position of about 5 metres above present sea-level at approximately $5.0 \mathrm{ky} \mathrm{BP}$. Similar phenomena were also observed in Australia (Woodroffe and Horton, 2005), Singapore (Hesp et al. 1998) and Thailand (Sinsakul, 1990) for the same period.

Hesp, et al. 1998 tested the Holocene sea-level rise reported for Malaysia (Tjia, 1992) and Thailand (Sinsakul, 1990) by taking dozens of radiocarbon samples at the coast of Singapore. The data showed a rapid postglacial marine transgression until about $6.5 \mathrm{ky} \mathrm{BP}$. The sea-level then peaked at about $+3 \mathrm{~m}$ between 6.0 and $3.5 \mathrm{ky} \mathrm{BP}$ and fell to the present level thereafter.

Even though all of the studies (Woodroffe and Horton, 2005; Hesp, et al., 1998; Sinsakul, 1990) show a comparable falling trend of the sea-level and the rise at about $3.0 \mathrm{ky} \mathrm{BP}$, they do not show another sea-level rise towards the end of the Holocene (ca 0.6 ky BP) observed by Tjia and Fujii (1989) for Langkawi Island on the west coast of the Malay-Thai Peninsula. These differences may be explained by how far away the observed locations are from the equator (considering the geoidal changing effect), the type of deposit materials sampled for the carbon dating, or the possible errors on the carbon dating interpretations. Moreover, there is a 
chance that tectonic activities occurred during this period at these specific locations (e.g. at Langkawi island studied by Tjia and Fujii, 1989). The influence of the latter effect to the coastal morphological development of Banda Aceh will be described later in section 2.4.5.

Langkawi Island, where Tjia and Fujii (1989) collected most of the west coast data, was the closest location to Banda Aceh, both belonging to the semienclosed Andaman Sea environment (inset of Fig. 1.1). Figure 2.5 depicts the Holocene shoreline fluctuations of Peninsular Malaysia by Tjia and Fujii (1989). Two envelope boundaries covering shoreline data of the sea-level trend at the west and east coasts of Peninsular Malaysia were suggested. Most data sampled on the west coast tend to follow the upper boundary, which was taken into account in the present study.

The development of Langkawi island on the west coast of Malaysia is considered closely related to the morphological development of the coastal plain in Banda Aceh. Therefore, it was used as the Holocene sea-level fluctuation indicator in the present study. The morphological development of the Holocene coastal plain of Banda Aceh was derived in the present study by using elevation data from the $0.5 \mathrm{~m}$ contour interval topographic map (section 2.2.2 and Table 2.1).

The following descriptions are the interpretations of the morphological development of the coastal plain of Banda Aceh based on the sea-level fluctuations by Tjia and Fujii (1989), and the topographic contour map of 2005 which was generated into a DEM (Table 2.1).

\subsubsection{Regional climate conditions and sedimentation during the Holocene}

The climate in the Holocene was probably more humid than during the Pleistocene low sea-level (Verstappen, 2000). The humid tropical conditions lead to intense chemical weathering, resulting in rapid alluvial planation. A significant supply of clay deposits by alluvial process, thus, prevailed.

Intense chemical weathering and followed by a glacial sea-level rise, the effect of offshore sedimentation in the shelf seas was profound. The clays carried in suspension by the rivers were deposited on the bottom of the shelf seas in the form of a nearshore clay blanket. This was apparently in accordance with delta progradation in the subaqueous part of the coast to form the convex shape of the shoreface profile especially in front of the massive alluvial plain at the southwestern part of Banda Aceh. This shoreface shape will be further discussed in section 2.5 . 
Bird (2000) described the conceptual models of a coastal profile development during a marine regression and transgression. We adopt these concepts to describe the possible development of the shoreface profile in front of Banda Aceh during the sea-level fluctuations of the Holocene in the following subsections. The interpretation of the sediment deposit was associated with processes described or given by other (Bird, 2000; Montagne, 1950; Schumm et al., 1987; Verstappen, 2000; Verstappen, 1973).

\subsubsection{Banda Aceh coastal plain shoreline of $4.0 \mathrm{ky} \mathrm{BP}$}

Following the development of young low terraces towards the mid-Holocene, a marine transgression occurred around $5.5 \mathrm{ky} \mathrm{BP}$. This first marine transgression of deglaciation followed consecutively the low terraces of Pleistocene. When the sea rose from its lowest level at the LGM (ca. $30 \mathrm{ky} \mathrm{BP}$ ) to a level of $+5.5 \mathrm{~m}$, the depressed portion of the tilted valley of Banda Aceh was quickly filled in with clay deposits which buried the earlier Pleistocene deposits (Montagne, 1950). Alluvial deposits however intervened in the SFS-associated depressed zone in (the southwestern coastal plain portion) and gradually increased in thickness to form a gentler terrain slope. The channel of the Krueng Aceh River developed its natural levees along with this alluvial progradation (Fig. 2.6b).

When the sea-level rise came to an end at around $5.5 \mathrm{ky} \mathrm{BP}$, the shoreface was probably formed in a smoothly concave profile (Bird, 2000). During the subsequent sea-level stand until around $4.0 \mathrm{ky} \mathrm{BP}$, the progradation of the shoreface was continued and the formation of successive low and broad beach ridges was developed. Verstappen (1973) suggested that such a set of low and broad belt beach ridges marks a phase of stability or minor temporary rise of sealevel.

At the northeastern portion of the Banda Aceh coast, the elevation was higher than that of the southwestern portion due to the tilting effect Pleistocene. The Pleistocene sandy deposits, which may be exposed across the sea floor profile offshore, gradually drifted shoreward over the formerly deposited clay blanket, driven by wave action. The sand drifting forms like a 'broom-sweep' pattern of sand ridges that are usually associated with this process (Bird, 2000), which can also be observed in the pattern of the consecutive old beach ridges complex occupying the northeastern portion of the coast (Fig. 2.6b). As the matter of fact, such typical ridge complexes occurred at many coasts around the world during the worldwide Late Quaternary marine transgression (Bird, 2000; Verstappen, 1953). 


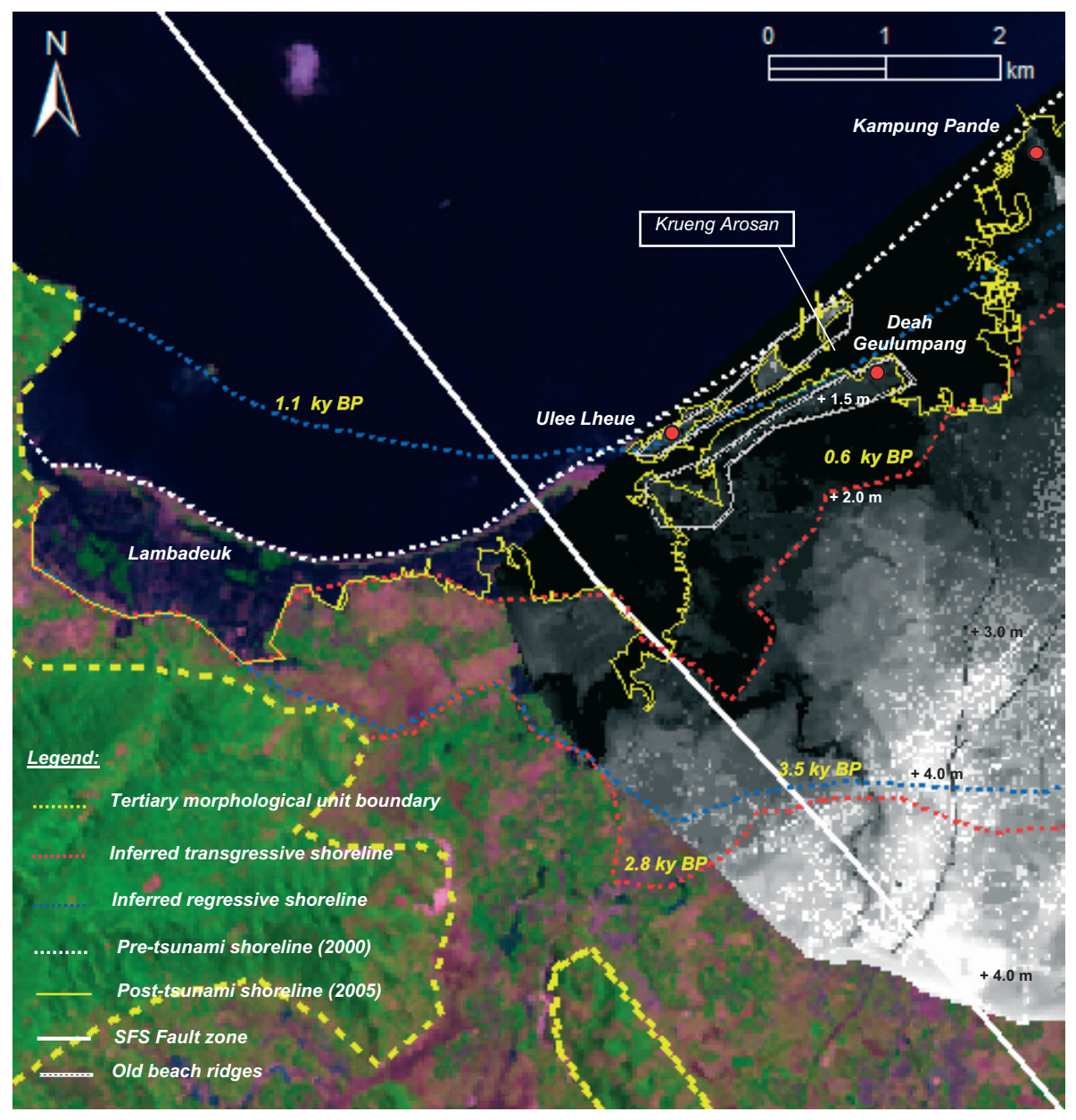

Figure 2.6: (a) The southwestern portion of the Banda Aceh coastal plain: Reconstruction of shoreline evolution and morphological unit identifications of the past millennia. The satellite image on the background was acquired in 2000 (Landsat ETM+7). The DEM of the coastal terrain of June 2005, i.e. 5 months after the tsunami of December 2004, is overlaid on top of the satellite image. 


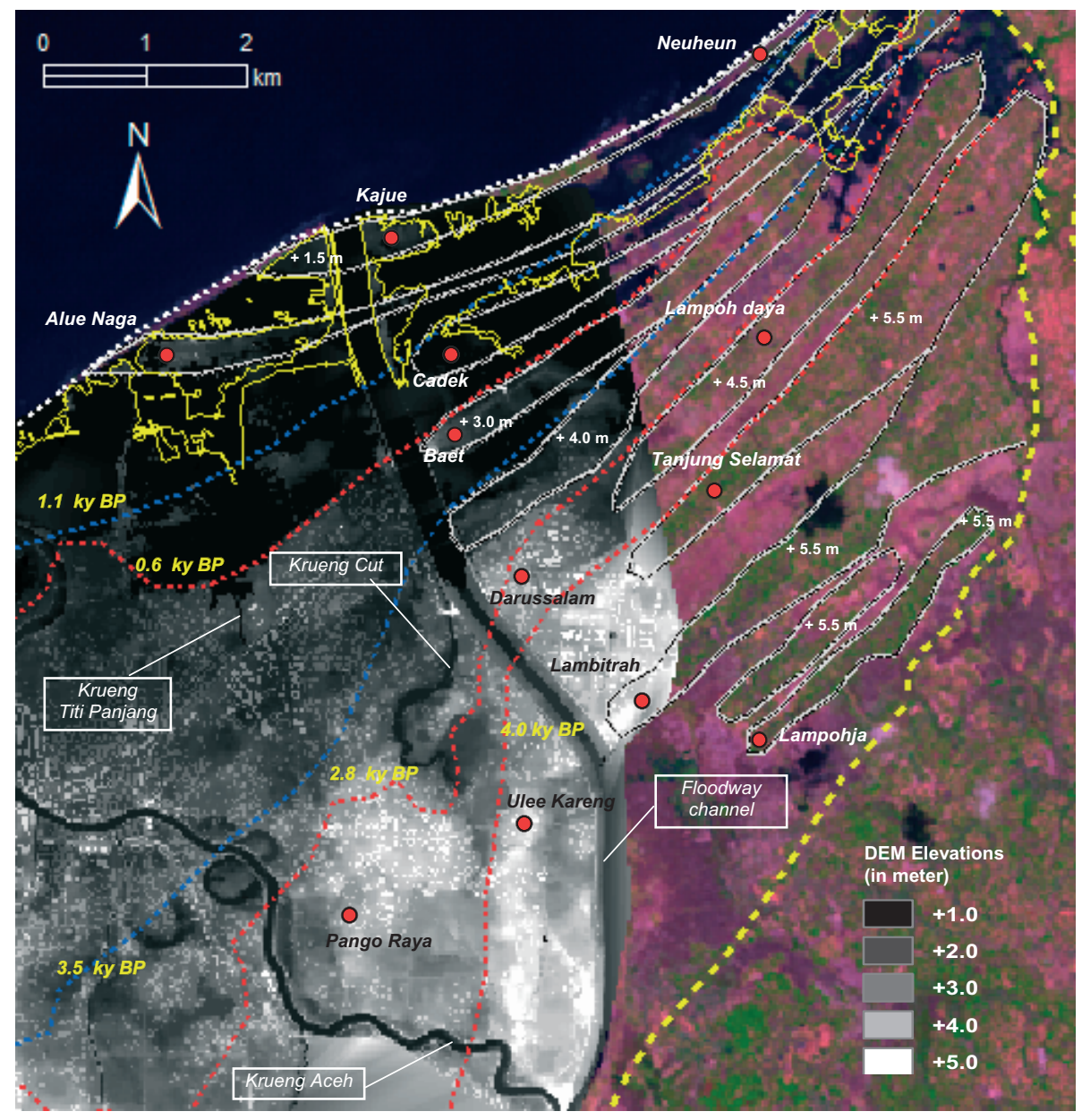

Figure 2.6: (b) The northeastern portion of the Banda Aceh coastal plain: Reconstruction of shoreline evolution and morphological unit identifications of the past millennia. The satellite image on the background was acquired in 2000 (Landsat ETM+7). The DEM of the coastal terrain of June 2005, i.e. 5 months after the tsunami of December 2004, is overlaid on top of the satellite image. 
In the topographic contour maps of 2005, this transgressive old beach ridge complex is where the villages of Tanjong Selamat, part of Darussalam, Lampohja and Lambitrah are situated (Figure 2.6b). Extensive elongated rice fields lie in the swale areas between the ridges. The development of the beach ridges during the high stand virtually ended at the seaward side of the Tanjong Selamat ridge, after which a regression set in. The natural levees of the Krueng Aceh river also developed towards similar elevations as indicated by the left- and right-banks of the river course that belong to Pango Raya and Ulee Kareng villages in the centre plain.

The successive parallel beach ridges between the swales including those formed by the marine regression process were determined by the rate of progradation (i.e. the rate of sand supply depends on sources and patterns of the sediment flow), the incidence of cut and fill, and the upper swash limit of the waves that built them, which is modified by changes in the relative levels of land and sea (Bird, 2000).

\subsubsection{Banda Aceh coastal plain shorelines of $3.5 \mathrm{ky} \mathrm{BP}$ and $2.8 \mathrm{ky} \mathrm{BP}$}

When the high stand of sea-level came to an end at $4.0 \mathrm{ky} \mathrm{BP}$, the sea-level gradually declined at a rate of $1.5 \mathrm{~mm}$ /year towards an elevation of +4.0 to $+4.5 \mathrm{~m}$ around $3.5 \mathrm{ky} \mathrm{BP}$, thus indicating the phase of marine regression. As the regression continued, the onshore sand drift continued as the waves actively transported the coastal sediment onshore. Another set of ridge complex was developed, however, with their crests decreasing seaward to correspond with the gradual sea-level fall. The Lampoh Daya ridge (Fig. 2.6b) was associated with this process. The terrain of this region was hilly with declining beach ridges crest heights; the Lampoh Daya crest was at $+4.5 \mathrm{~m}$ and Darussalam was at +4.0 to $+3.5 \mathrm{~m}$ whilst the rest of the alluvial plain on the southwest portion towards the shoreline of $3.5 \mathrm{ky} \mathrm{BP}$ was at +4.5 to $+4.0 \mathrm{~m}$. This marine regression occurred in a shorter period compared to the second regression occurred after $2.8 \mathrm{ky} \mathrm{BP}$ (described in section 2.4.5). The regressive shoreline of $3.5 \mathrm{ky} \mathrm{BP}$ denoted the end of this marine regression phase.

Following this early marine regression, a new but shorter period of transgression occurred until about $2.8 \mathrm{ky} \mathrm{BP}$ at a level of $+4.0 \mathrm{~m}$ according to Tjia and Fujii (1989). The estimated rate of this rise was about $1.6 \mathrm{~mm} /$ year. The coastal elevation from the DEM indicates that this phase of marine transgression may have affected as far inland as Darussalam. In this particular case, processes similar to the earlier sea-level high stand occurred, although over a shorter 
duration. According to Schumm, et al. (1987), in the development of a coastal plain, a rising sea-level followed by a high stand may encounter large quantities of clayey sediment brought to the sea by the river. This brought about a remarkable development of the river channel sinuosity which can be observed by the localized river sinuosity occurring at Krueng Cut River and the course of Krueng Aceh River between the shoreline 2.8 ky BP and $3.5 \mathrm{ky}$ BP (Figure 2.6b).

It was explained earlier in subsection 2.4.1 that there might have been a rise of sea-level at about $3.0 \mathrm{ky} \mathrm{BP}$ in some locations around this region (see Woodroffe and Horton, 2005; Hesp, et al., 1998 and Sinsakul, 1990). There was no clear explanation, however, about the cause of this broad effect of sea-level rise; whether it was either due to deglaciation or due to tectonics/tsunami.

\subsubsection{Banda Aceh coastal plain shorelines of $1.1 \mathrm{ky} \mathrm{BP}$ and $0.6 \mathrm{ky} \mathrm{BP}$}

The remaining coastal terrain following the short phase of transgression was controlled by another prolonged marine regression at a rate of $1.6 \mathrm{~mm} /$ year (see also the sea-level curve in Fig. 2.6b). The sea-level was falling until slightly above the present level $(+1.0$ to $+0.5 \mathrm{~m})$ at around $1.1 \mathrm{ky} \mathrm{BP}$. Another set of broad and gently sloping coastal ridges developed accordingly. Alluvial deposits spread across the entire coastal plain, with elevations of +3.0 to $+1.5 \mathrm{~m}$. The SFS-associated depression zone and the central plain were filled in towards the same level as the rest of the plain.

Assuming the regression process continued without any major disruptions (such as a vertical tectonic movement or impact of a tsunami) the shoreline curvature may have become smoother by wave action and the shoreline eventually connected Ujong Pancu and Ujong Batee headlands. The shoreline of $1.1 \mathrm{ky} \mathrm{BP}$ depicted in Figure 2.5a is a re-constructed shoreline based on this assumption.

This new shoreline developed concurrently with the development of the downstream reach of Krueng Aceh River where the sinuosity of the channel increased. Two ancient courses of the Krueng Aceh River were found in the central portion of the plain. The Krueng Cut developed seaward from its upstream incision during the previous sea-level rise (i.e. after $2.8 \mathrm{ky} \mathrm{BP}$ ), and the more recent the Krueng Titi Panjang (near the present Governor office of Nanggroe Aceh Darussalam Province) was developed towards the end of the regression phase. This is the area where Banda Aceh city centre is situated.

Two consecutive patterns of beach ridges with crest elevations of +2.0 and $+1.5 \mathrm{~m}$ relative to PSL is depicted in Figure 2.6a (i.e. where the Baet and Cadek 
villages are situated). The seaward lowering of the beach ridges suggested that their developments were associated with the regression phase. Marine sediment was probably most predominant during this phase of a shoaling sea water environment, which provided enough source material to develop beach ridges by the shoreward sand drift. In this case, the beach ridges stretched as far as to the centre plain (i.e. Alue Naga Village in Figure 2.6b). This may also suggest that by this time the tilting effect from the base planation of the Pleistocene was gradually reduced.

The sea-level fluctuation at the west coast of Peninsular Malaysia succeeding this period is noteworthy in comparison with the sea-level indications at the other locations in the Southeast Asia and Australia. Sinsakul (1990) suggested that at Ko Kaew, southwest coast of Gulf of Thailand, the succeeding regression after $2.5 \mathrm{ky}$ $\mathrm{BP}$ brought the sea-level down until it reached its present datum (sea-level) at around $1.5 \mathrm{ky} \mathrm{BP}$, and apparently stayed at that elevation until today. A similar hindcast of linear and oscillating regression models from sea-level index points was also suggested by Baker, et al. (2001) that in southeast Australia, the sea-level of ca. $+1.5 \mathrm{~m}$ at around $2.0 \mathrm{ky} \mathrm{BP}$ has since tapered out towards the present sea-level.

In contrast, Tjia and Fujii (1989) observed that there has been once again a significant sea-level rise occurred in Langkawi Island at around $0.6 \mathrm{ky} \mathrm{BP}$ when it reached $+1.5 \mathrm{~m}$ from the present sea-level. The curve in Figure 2.6b following the data points around this period may suggests the rapid sea-level rise. The sea-level curve derived from sample data by Tjia and Fujii (1989) may be considered too sparse to ascertain that this local effect has occurred. Nevertheless, archeological reports about the Banda Aceh coast during this period and evidence from the morphological imprint of the present coast in Banda Aceh may support this view.

McKinnon (1988) quoted important archeological manuscripts on Lambri, which referred to the Lambadeuk beach, i.e., the sunken coast at the embayed coastal section on the southwestern part of the Banda Aceh coast (Fig. 2.6a). An Arab geographer, Akbbar al-Sin wa'l Hind referred to Ramni, which is situated in the northwestern tip of Aceh and described the situation at this location before the $9^{\text {th }}$ century (i.e. ca $1.0 \mathrm{ky} \mathrm{BP}$ ) as follows: "the island is washed by two seas ... Harkand and that of Salabit". The sea of Harkand was the Bay of Bengal, while Salahit was the Malacca Strait (McKinnon, 1988). Furthermore, in circa 943 AD (i.e. 1.0 ky BP), Masudi stated for this location by: 'the years that have many storms and earthquakes'. In 1349 AD (i.e. 0.6 ky BP) Wang Ta-yuan, a Chinese traveler wrote: "This place is the most important trade centre in Nan-wu-li (i.e. north tip of Aceh). Great mountain-like waves dash against $i t, \ldots$.. The chronological coincidences of these 'extreme events' suggest that tectonic activities and most probably a tsunami had occurred around $0.6 \mathrm{ky}$ 
BP (ca. 700 years ago; Fig. 1.3) in this coastal area before the one that occurred on 26 December 2004.

The coastal morphology associated with this period in Banda Aceh strongly suggests the impact of these extreme events. When the last marine transgression occurred at around $0.6 \mathrm{ky} \mathrm{BP}$, the sea-level rose to a level of $+1.5 \mathrm{~m}$ from the present sea-level. The incoming wave of the scale of a tsunami magnitude must have attacked the coast, leading to the breaching of the two consecutive beach ridges at Baet and Cadek on the seaward side of the $1.1 \mathrm{ky} \mathrm{BP}$ shoreline (Figure 2.6b). The two beach ridges were developed earlier during the last regression phase.

During the successive short period of high stand, the submerged regressive coastal plain turned into a mild slope submarine terrace. This created an inter-tidal corridor that allowed a wetland environment to develop by weak incoming waves and a stronger tidal influence. Mangroves may have flourished hereafter, while the submarine bars were drifted shoreward.

At the Banda Aceh coast, the rivermouth of Krueng Aceh River progressively shifted northeastward as the increasing thickness of sediment may have closed the river course leading to the older rivermouth (e.g. Krueng Arosan River in Figure 2.6a). The rivermouth gradient became gentler by the increasing of fine sediment thickness which forces the rivers find its way to the sea through meandering towards the northeast. The outer belt of beach ridges belonging to Ulee Lheue, Kampung Pande, Alue Naga, Kajue and Neuheun were created during the last regression phase after $0.6 \mathrm{ky} \mathrm{BP}$. This suggests that the abovementioned beach ridges that define the shoreline boundary of the present Banda Aceh coast has been established since the late Holocene. In particular, the beach ridges of Kajue and Lambadeuk might be younger than the other outer-belt beach ridges. Since Lambadeuk is located in the deeper part associated with the SFS zone trench, the beach ridge was not as extensively developed as that of the Kajue or Alue Naga (Fig. 2.6b) which is located on the shallower part.

Under a similar climate condition as Jakarta Bay in Java (Verstappen, 1953), it is expected that the shoreline response of the Banda Aceh coastal plain to sealevel fluctuations during the Holocene was influenced by the mechanisms of repeated changes of rivermouths and intermittent beach-ridge formation caused by periods of above average onshore winds. 


\subsection{Coastal evolution near Banda Aceh over the past century}

\subsubsection{Recent morphology and data processing}

The Banda Aceh coast in the recent time (pre-tsunami) consisted of a narrow sandy beach perched on top of the toe of the beach ridges of the older morphological units. The preceding development has made the modern coast of Banda Aceh to be highly dissected within a $25-\mathrm{km}$ coastal stretch.

The position of the beach ridge after the land subsidence and tsunami in ca. $0.6 \mathrm{ky} \mathrm{BP}$ may be considered as the starting point of the modern morphological development of the wetland area of the coast. It seems that the delta progradation by alluvial processes had terminated in the late Holocene. This is because the land denudation may have been much reduced towards the end of the late Holocene during which the Inter-tropical Convergence Zone (ITCZ) has moved up north resulting in milder wind and temperature (Verstappen, 1980).

During the last couple centuries, the coastal processes were influenced by the seasonal wave direction changes due to the two monsoonal climates. The southwest monsoon occurs between April and September and is characterized by relatively rough waves coming from the northwest. About 53\% of the waves approach the coast with a significant wave of $1.0 \mathrm{~m}$ high with a wave period of 3 seconds. During the northeast monsoon between October and March, the climate tends to be milder with $40 \%$ of the waves approaching from the northeast with a significant wave of also $1.0 \mathrm{~m}$ height and a wave period of 4.5 seconds (data derived from a statistical analysis of ten-year daily wind data, recorded by the Department of Meteorology and Geophysics in Banda Aceh from 1995 to 2005; Meilianda et al., 2006).

Man-made structures such as of coastal protection (e.g. seawall), rivermouth regulations (e.g. training jetties), flood control (e.g. Alue Naga Floodway channel) and inter-island navigation (e.g. Ulee Lheue ferry port) started in the early 1990 s. This means that the human intervention practically affects the coastal morphological development at a time-scale shorter than the one of interest in the present study. Therefore, in the following description this is being discussed as a localized and minor effect (if any) to the decadal scale of morphological development. Nautical charts of the Banda Aceh coast in 1893 and 1924 and bathymetric data in 2006 (i.e. one year after the tsunami in December 2004) were used to examine the shoreface profile changes (Table 2.1). 


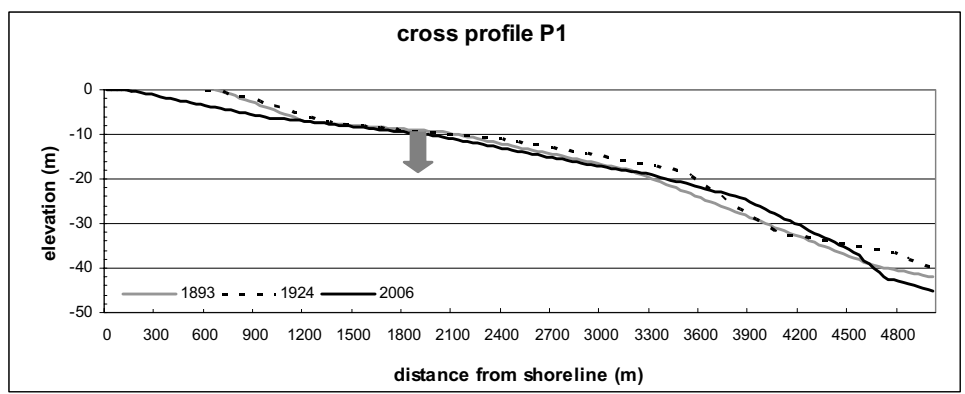

Poorly graded sand (very loose)

Sandy clayey silt (stiff)

Sandy clayey silt (stiff) Silty sand (loose)

(a)

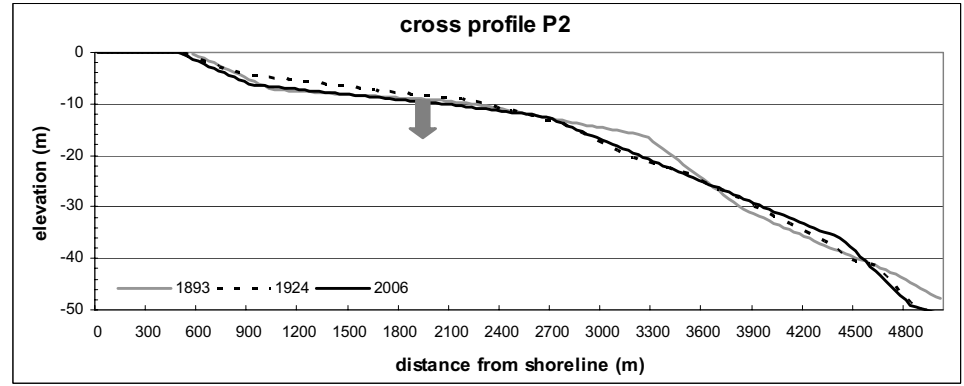

Poorly graded sand (very loose)

Sandy clayey silt (stiff)

Sandy clayey silt (stiff)

Silty sand (loose)

(b)

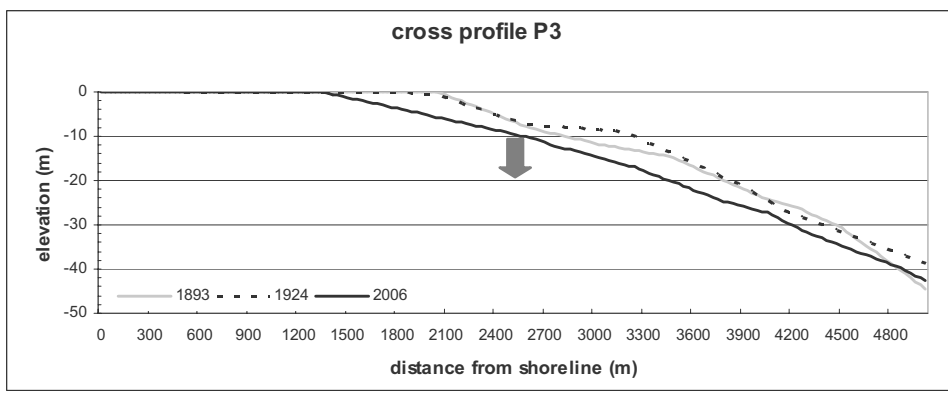

Poorly graded sand (very loose)

Sandy clayey silt (stiff)

Sandy clayey silt (stiff)

Silty sand (loose)

(c)

Figure 2.7: (a,b,c) Shoreface profile development in the past century and the associated bore hole samples. The downward arrows point at the sample locations. The right panels of each profile display the stratification of the samples. Profile locations are in Figure 2.3a. 


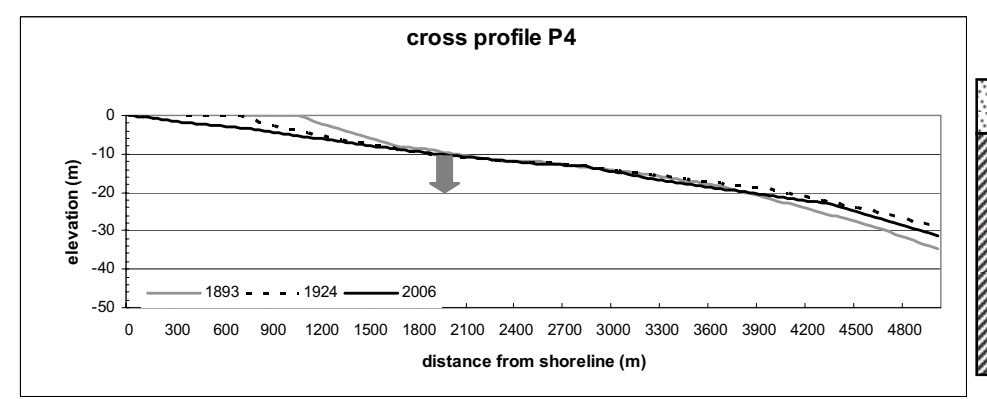

Poorly graded sand (loose) Sandy silty clay (very soft)

(d)

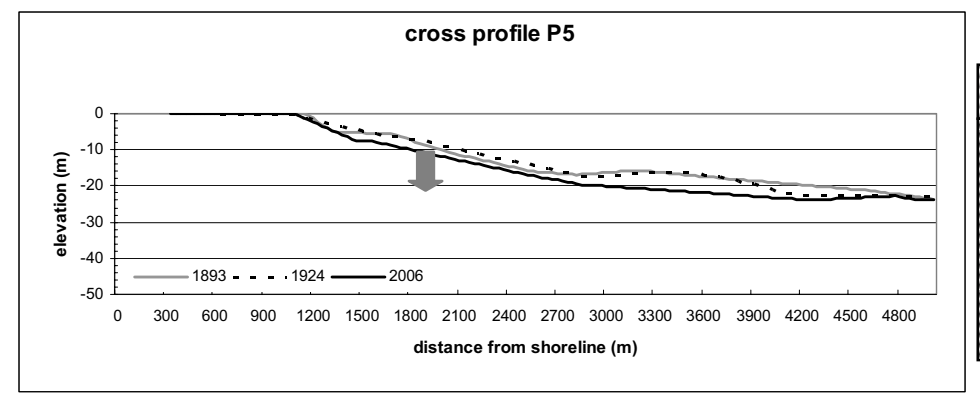

silty clay (soft) Sandy silty clay (medium stiff)

Scale of sample thickness:

(e)

Figure 2.7: (d,e) Shoreface profile development in the past century and the associated bore hole samples. The downward arrows point at the sample locations. The right panels of each profile display the stratification of the samples. Profile locations are in Figure 2.3a.

The shoreface profiles displayed in Figure 2.7 show different developments between the two points in time before the tsunami (i.e. 1893 and 1924) and the profile after the tsunami (i.e. 2006). We have a data set of 2001 which is the bathymetric measurement of the seaward extent of the coast. However, the data are very limited only until the bathymetry of $-7.5 \mathrm{~m}$. From this data, we observe that the upper shoreface profile has not changed so much from the one of 1924, therefore, we assumed that the change of shoreface profile from 1924 to 2001 is not really important in this case.

Geomorphological analysis of the past centuries in this section discusses only the morphological development of the shoreface in front of Banda Aceh coast by taking into account the morphological changes of five representative cross-shore shoreface profiles (P1, P2, P3, P4 and P5 in Fig. 2.7). Each profile 
show the elevation changes of three points in time within the recent century, i.e., before the tsunami (1893 and1924), and after the tsunami (2006). The profiles were also accompanied by information on the type of sediment and geomorphic settings that were inherited from the longer time-scale morphological development that was analysed earlier in section 2.3 and 2.4.

Some important remarks on the deviation of marine/climate condition and tectonic activities in the history leading to specific coastal morphology that was suspected to have occurred due to these intermittent forcing factors will be discussed a more detail in Chapter 4. In the following, the changes of the shoreface morphology associated with the tsunami in 1907 (discussed in more detail in Chapter 4) and in December 2004 are analysed by using three consecutive bathymetric data of 1893, 1924 and 2006.

\subsubsection{Shoreface morphology over the past century}

\section{Shoreface near Lambadenk (Profile P1)}

Profile P1 represents the coastal section at Lambadeuk, an embayed coast with a convex shoreface. The coast is located on the southwest side of the SFS fault zone. This portion belongs to the more active section of the fault zone which makes it subject to land subsidence due to neotectonic movements. Accordingly, the shoreline position was remarkably dynamic compared to the rest of the coast. The shoreface has a convex shape which developed as a prograding delta during the Holocene. The average slope of the shoreface was rather mild where a $20-\mathrm{m}$ depth was reached at a distance of $2.8 \mathrm{~km}$ from the shoreline. Due to the tsunami of December 2004, the entire shoreface was slightly eroded in the centre part and part of the material was deposited at the lower part of the shoreface (Fig. 2.7a).

The bore hole data associated with the profiles in Figure 2.6 were acquired in 2006 from the Sea Defense Consortium for the Rehabilitation and Reconstruction (SDC - BRR) after the tsunami in Banda Aceh. After the tsunami in December 2004, the loose sediment at the shoreface consisted of only a relatively thin layer of silty clay (mud). Moreover, the older underlying shoreface structure which developed during the Holocene probably was highly resistant to the tsunami wave force preventing it from severe erosion. As mentioned in subsection 2.4.5, the Lambadeuk beach ridge consisted of material that is younger than the other part of the coast. This might mean that it was less consolidated 
compared to the beach ridges on the northeastern part (probably also consists of different material). This beach ridge was completely destroyed by the tsunami.

\section{Shoreface near Ulee Lheue (Profile P2)}

A clear slope break on the shoreface profile P2 was identified at $-15 \mathrm{~m}$ depth, about $2.7 \mathrm{~km}$ from the shoreline. Herein, the shoreface width was getting narrow. This shoreface profile which is located near Ulee Lheue also has a convex shape induced by the Holocene alluvial process, which suggests that delta progradation influenced the morphological development. The old rivermouth of the Krueng Cakra probably contributed sediment to the coast in the late Holocene, which s no longer the case in the modern times as it has migrated to the location where the Krueng Aceh rivermouth is situated at present (see also explanation in subsection 2.4.5). From the shape of the shoreface profile and the sediment deposition of stiff clayey silt underneath thin layer of loose sand, the shoreface morphology of the beach ridge and shoreface of Ulee Lheue had been established during the late Holocene, probably between $1.1 \mathrm{ky} \mathrm{BP}$ and $0.6 \mathrm{ky}$ BP. The seaward portion of the barrier island was severely eroded during the December 2004 tsunami. The entire shoreface profile was eroded down to 'consolidated material'; i.e. a stiff layer of sandy clayey silt (see bore hole data associated with profile P2 in Fig. 2.7b). Some part of the eroded material seemed to be deposited offshore.

\section{Shoreface near Krueng Aceh River mouth (Profile P3)}

In this coastal section, the shoreface profile became considerably steeper than the other two profiles. The fine material of about $5 \mathrm{~m}$ thick in the bore hole data of this profile was most probably supplied from the Krueng Aceh River. In 2000, a pair of training jetties was fully installed on both sides of the river mouth. From several Landsat ETM+7 satellite images from 2000 to 2003 (not displayed in this thesis) we observed that the longshore transport of littoral sediment was highly disrupted, and the sediment supply from the river might have been deposited further offshore at the lower part of the shoreface.

The underlying Holocene deposits may have built a convex shape shoreface profile which extended offshore, but the younger sediments perched on top have a concave profile shape in the nearshore zone. In 1924, the unconsolidated young material probably drifted onshore due to the wave surge from the tsunami of 1907, and further modified until it reached the profile shape in 1924 (Fig. 2.7c). The 
shoreline at this coastal section retreated about $400 \mathrm{~m}$ from 1898 to 2000, suggesting that the sediment supply from the river has been much reduced.

The sediment supply from the Krueng Aceh River consists of fine material which seems to bypass the littoral zone and deposited further offshore, especially after the construction of training jetties at the river mouth in 2000. This river mouth location is the most recent location of the rivermouth since the migration during the Holocene. Based on the bore hole sample in this region, it is reasonable to identify that the upper layer of the shoreface in this region is composed by younger deposits (see bore hole data of profile P3 in Fig. 2.7c). Consequently, when the tsunami of 2004 wave hit the shoreface, it most probably eroded this unconsolidated shoreface tremendously.

\section{Shoreface near Kuala Gigieng inlet (Profile P4)}

Profile P4 is situated in the vicinity of the mouth of Kuala Gigieng inlet. In the past century, the estuary mouth has been very dynamic where the longshore sandspit grew alternatively northeastward or southwestward depending on the net littoral transport direction which was pre-dominant in some consecutive years. Marine processes seem to be pre-dominant at this coastal section. This is inferred from the concave shape of the upper shoreface, whilst a convex profile shape can still be observed at the lower shoreface further offshore. An extreme wave event seems to have modified the shoreface profile in 1924 and the shoreline retreated (i.e. the upper most of the shoreface), whilst a considerable amount of deposition was found on the lower part. The centre part of the shoreface profile, however, remained unchanged even after the tsunami on December 2004. This may be explained by the fact that the morphological unit at this particular location consisted of consolidated material and the (cross-shore) marine sediment transport on top of it bypasses from the upper part (the beach/sand spit) to the lower part of the shoreface.

\section{Shoreface near Ujong Bate headland (Profile P5)}

Profile P5 represents the coastal morphology in front of the Ujong Bate, a headland which was tilted in the Pleistocene. The shoreface tends to form a concave-shape profile. The upper shoreface of the profile in 1898 consisted of a narrow submarine terrace of ca. $350 \mathrm{~m}$ width at a depth of $-5 \mathrm{~m}$. Going offshore, the slope was steep at a distance of $0.9 \mathrm{~km}$ from the terrace, but followed by 
bathymetric highs. This implies that the coastal environment on the tip of the headland has sufficient source of marine sediments to feed the beach development. Most probably it was derived from the eroding cliff associated with Ujong Batee, and also from the old morphological units such as the old beach ridges at the seaward boundary (more detailed explanation in Chapter 4). This may explain the dynamics of the sand spits growth at this coastal section. The shoreface was severely eroded during the December 2004 tsunami, which also destroyed the submarine bar system and made the entire shoreface became considerably deeper. The beach was protected by the old beach ridges (e.g. at Neuheun in Figure 2.6b) which prevent the shoreline from retreating considerably, but the beach ridge itself was breached.

\subsection{Discussion}

\subsubsection{Forcing factors in history of morphological development of Banda Aceh}

The interpretations of the morphological development of Banda Aceh coastal plain are summarized in a cascade model (Fig. 2.8). This cascade model provides an overview of the prevailing processes during a particular period in history, and furthermore distinguishes the morphological units developed during those periods. This study revealed that many forcing factors that have been involved in shaping the morphology of the Banda Aceh coast today, and each period in the geological time-scales revealed different development of morphology involving completely different forcing factors.

Epeirogenesis and orogenesis processes were strongly influential in the early geological periods (Eucene to Miocene). Large-scale tectonic movement during the Tertiary period was configured as the basement and the outer boundary of the geomorphological development of the modern Banda Aceh coastal plain. The tilting process related to the last orogenesis in this region accentuated the different coastal landscape from the northeastern to the southwestern part of the coastal plain. On the other hand, extreme sea-level fluctuation leading to the present sealevel was involved in shaping the coastal plain on top of this tilted bottom topography. The sea-level fluctuations during the Holocene due to the global icemelting caused phases of marine transgression and regression, leading to the formation of beach ridges and swales on the northeast and an extensive and rather flat alluvial plain on the southwest part of the coastal plain. Verstappen (1953) also studied similar types of beach ridges and swales complex in the Jakarta Bay, Java 
Island. He suggested that the surface area of beach ridges may easily lead to an overestimate of the amount of sand. The beach ridges and swales formations contained only thin lenses of sandy deposits, measuring a few meters in depth, intercalated with clayey deposits (e.g. Chenier-like ridges). Such type of deposit was also observed from the borehole data on the Banda Aceh coastal plain (Fig. 2.7).

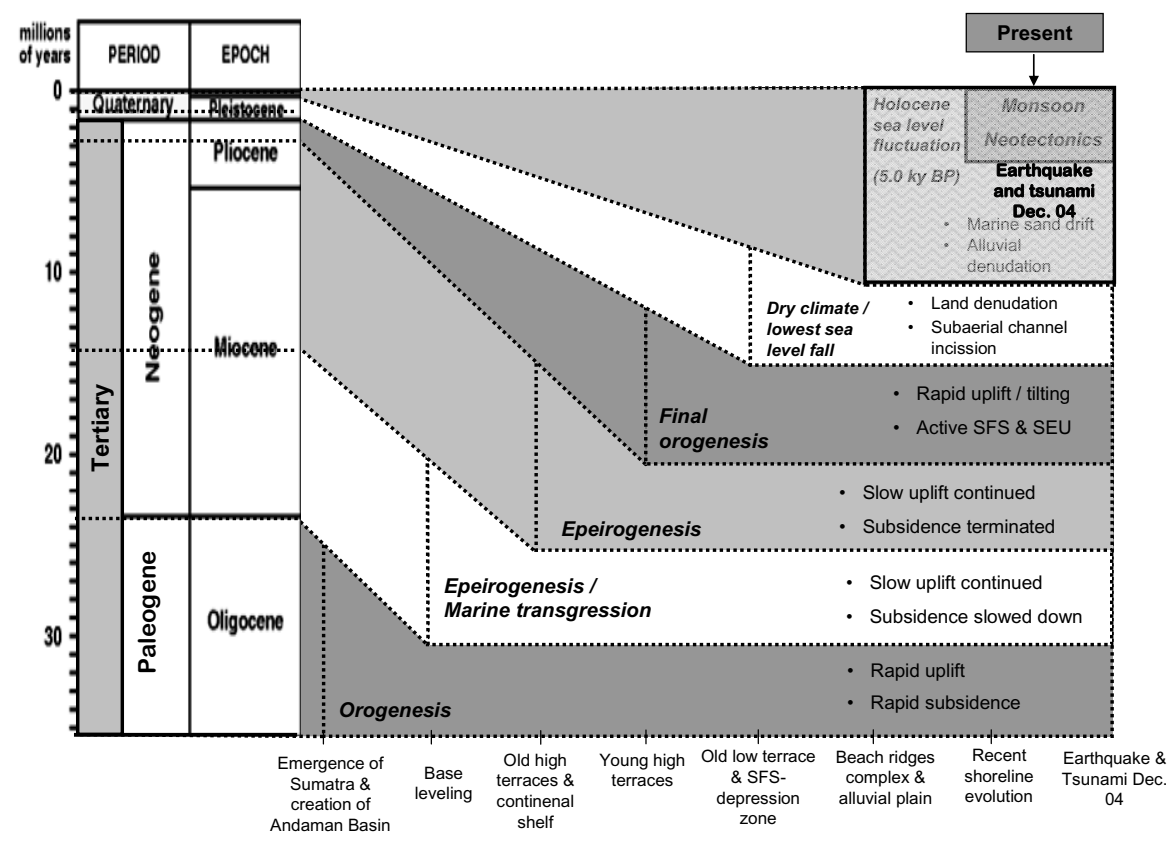

Figure 2.8: Cascade model of the Banda Aceh coastal morphology showing the relationship between the creation of morphological units (abscissa) in different period encompassing geological to decadal time-scales (ordinate) and identification of forcing factors during the development.

\subsubsection{Remarks on the tsunami return period in a long time-scale}

Parallel to the completion of this thesis, several new findings about the recurrence of tsunami events in the Indian Ocean region have been emerged. Monecke, et al. (2008) suggested that the correlation of three in-situ sediment coring at Meulaboh (west coast of Aceh), Simeulue (offshore west coast of Aceh) and Phra Thong (west coast of Thailand), were an age range of sediment deposit layers unconformity which was correlated with historic tsunami occurrences in this region. 
Two sample units in Meulaboh and Phra Trong suggested the ranges of age of the deposit of AD 1290 to 1400 (or 660 to 550 y BP) and AD 1300 to 1450 (or 650 to 500 y BP), respectively. In their report, they used the age estimates of coastal terraces in the Andaman Islands region by Rajendran, et al. (2008) to confirm their interpretation as evidence for subduction earthquakes. The problem with estimates made by Rajendran, et al. (2008) was that the range of age they provide was considerably large. The marine terrace of Andaman Islands was suggested to age of AD 1170-1600 and AD 550-1330 (or equal to 750-350 y BP and $1400-620$ y BP). In this study, we reduced this uncertainty by providing a better confirmation to the analysis of big tsunami recurrence studied by Monecke, et al. (2008).

Looking beyond this specific time-scale (the last millennia), we have shown in section 2.4 the alternating marine regression/transgression with respect to the sea-level fluctuation in the Holocene. It is interesting to find the coincidences of changing phase between marine regression and transgression inferred from the sea-level fluctuation by Tjia and Fujii (1989) and specific identified morphological units on Banda Aceh plain (e.g. the localized river course sinuosity and the breached old beach ridges) that happened to occur within 500 to 600 years interval; i.e from $0.6 \mathrm{ky}$ BP to $1.1 \mathrm{ky} \mathrm{BP}$ and from $2.8 \mathrm{ky} \mathrm{BP}$ to $3.5 \mathrm{ky}$ $\mathrm{BP}$, respectively. This is provided that the recurrence of the big tsunamis in the last millennia; i.e. the December 2004 and in around $0.6 \mathrm{ky} \mathrm{BP}$ which has an interval of $\sim 700$ years. These pulses of 'abrupt sea-level change' occurred roughly in every two thousand years interval during the long-term sea-level fall in the Holocene (from ca. $5.5 \mathrm{ky} \mathrm{BP}$ until present). From the data we used in this study, it is perhaps too early to suggest whether the coincidences of sea-level rise of the earliest two abrupt change of morphology were as the results of the same forcing factors, such as tsunami, eustatic sea-level rise or tectonic movement.

At the end of the regression phase of the last millennia (e.g. after the suspected tsunami in $0.6 \mathrm{ky} \mathrm{BP}$ ) the top layer of sediments deposition in the shoreface zone may be started. From the borehole samplings in Figure 2.7 it can be observed that most of the second layer or the intercalated layers underneath the top layers of the profiles on the southwestern part of the coast (P1 and P2) consist of stiff layer of deposits. This deposit layer was most probably associated with the delta progradation during the last Holocene. Furthermore, we supposed that the intercalating layers found near the SFS fault zone (e.g. P2) was influenced by some tectonic-related event (e.g. land subsidence or tsunami). Moveable fine sediments were subsequently perched on top of this Holocene basement layer. The Holocene 
deposit as the product of the prograding delta process consisted of very fine sediments (e.g. silty clay or clayey silt; or simply mud) which eventually becomes a stiff structure of deposit layer in a long time and becomes the basement of the subsequent development (marine regression).

During the phase of marine regression (Bird, 2000) as the sea-level was falling, marine influence was pre-dominant. Marine sediments, depending on how much was available, were brought onshore to form a new morphological unit on top of the older ones. Profile P5 in Figure 2.7 consists of loose and sandy sediment layers which are considerably thick compared to the other profiles. This deposit seems to be associated with this regression phase.

In addition, the concave shape of the shoreface profiles shows the characteristics of the regressive coast (Bird, 2000). Here, the marine regression was predominant, probably since the late Holocene. Nevertheless, the wave regime during this period may be much different from the present situation. The modern morphological development of the Banda Aceh coast is influenced by the monsoonal wave climate that induces seasonal wave direction changes which influences the coastal processes. Therefore, in the recent period of morphological development (e.g. in the last centuries) the new materials were coarser than those of the underneath layer. This new deposit accumulation also occurred on the tectonically unstable coastal portion (e.g. at the coast represented by profiles P1 and P2), although probably with a different rate of deposition. This is displayed by the concave shape of the upper shoreface profiles of the entire coast which is associated with fine sand that configures the modern beaches in this coast.

The modern Banda Aceh coast seemed to be of similar type of the U.S. Atlantic coast, in a smaller version. Typically for this type of coast according to Riggs, et al. (1995), is that the continental margins has limited sand supplies, thus, the shoreface is not an infinitely thick pile of sand. Rather, it is a thin, variable, and temporal accumulation of sand superimposed or perched upon a pre-existing and highly-dissected coastline. More specifically, Sunamura (1992) define this type of coast as a rocky coast.

\subsubsection{Tsunami impact against different coastal geomorphic settings}

The aforementioned history and processes involved in the morphological development of the Banda Aceh coastal plain leads to a better understanding about the inherited geomorphic settings of the coastal area, which in this case we focus on the shoreface of 5 particular coastal profiles along the Banda Aceh coast, and 
how each of them responded to the earthquake and tsunami on 26 December 2004.

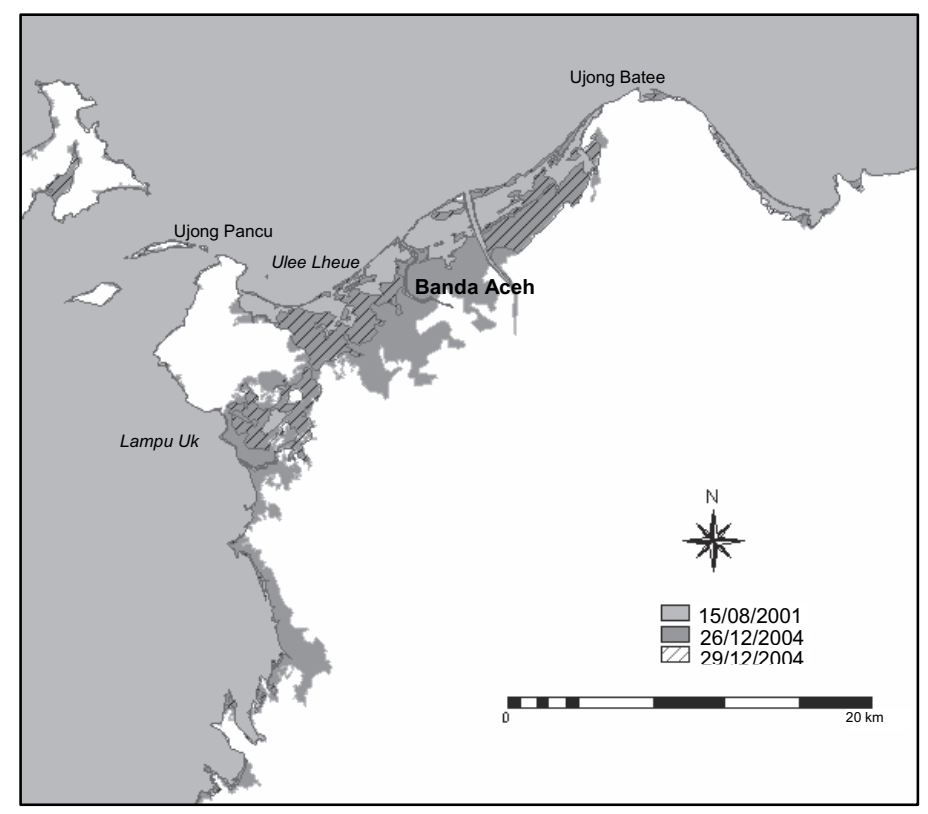

Figure 2.9: Inundation pattern of the tsunami waves in Banda Aceh. The red zone is the tsunami inundation on the day of the event, the yellow zone is the inundation pattern after 4 days and the pre-tsunami wetland is denoted in blue zone. The legend denotes the date of acquisition of satellite images (Landsat ETM+7) of which the inundation assessment were analysed.

In the 2004 tsunami, the inundation by seawater reached as far as $5 \mathrm{~km}$ inland, crossing the entire coastal plain of Banda Aceh that was already established since $3.5 \mathrm{ky}$ BP (compare the tsunami inundation with the shoreline position of 2.8 ky BP in Fig. 2.9). It has left sediment deposition of various thickness and texture among the ruins and debris. The outer belt of beach ridge was mostly breached (i.e. at Ulee Lheue, Alue Naga and Neuheun), and even completely disappeared (i.e. Lambadeuk). After four days, the inundation reduced to about $50 \%$ from its initial extent (see also Dohmen-Janssen et al. 2006), which changed the low-lying housing areas, wetland and lagoon system behind the barrier islands to submerged 
areas. These areas are somehow associated with the one that morphologically modified by the last marine transgression (i.e. tsunami) in $0.6 \mathrm{ky} \mathrm{BP}$. This shows that a huge tsunami event occurrs only in a very short time-scale, but it leads to changes in morphology comparable to changes that normally occur on a time-scale of centuries to millennia.

The shoreface profile of Banda Aceh in response to the tsunami (see profiles 1924 and 2006 in Fig. 2.7). However, the amount of eroded shoreface sediments varied from one profile to another. Interestingly, each shoreface profile maintained its convexity or concavity upon being eroded by the tsunami. The upper layer of the shoreface consists of young loose sediments underlain by the more consolidated morphological units (see bore hole data in Fig. 2.7) which were developed most probably as the combination between alluvial and regression processes during the Holocene. As a result, the upper layer were easily eroded during the tsunami (e.g. soft clay or silty layer deposit at the upper shoreface of profile P1 and the entire profile P3), while the shoreface composed by older deposits were less eroded (e.g. profiles center part of profile P1, profile P2 and P4). The shoreface erosion has modified the shoreface profiles of the entire coast and therefore has eventually modified the hydrodynamics of the coastal system.

From the description of the five representative shoreface profiles, it is clear that the convex shoreface was influenced by the pre-dominant alluvial progradation during sea-level regression, whilst the concave shoreface was influenced by sea-level regression process during the Holocene. In addition, the resistance of the shoreface against severe erosion by the tsunami waves may depend on the degree of consolidation or the rate of weathering of the shoreface deposits. On the other hand tectonic intensity must be influential in the consolidation processes (e.g. liquefaction or compaction) on a specific coastal section preceding the December 2004 tsunami. In particular, tectonics and extreme waves such as tsunami have left their signature in the present morphology.

When the tsunami hit the coast, the older stratigraphic unit across the shoreface might have been eroded, stirred and deposited elsewhere. The eroded sediments made its contribution as a new deposited layer of the modern coastal morphology that will be imprinted in the geological history of this coast. At the coastal section associated with the SFS fault zone (i.e. the northwest coastal section), the tectonic activities have caused land subsidence. Consequently, the coastal morphological development under normal condition which expected to occur continuously has been disrupted many times, and each time the disruption 
occurred, it determines the new morphological state after which the future development should start.

Regarding the complexity of the processes involved and the resulting morphology, proper attention should therefore be given to the boundary conditions which are imposed by the development of older morphological units. The complex geomorphology underlying the Banda Aceh coastal plain resulted from various processes in history ultimately determines the shoreface geomorphic settings and the morphological development, composition and texture of beach sediments, and the rates of shoreline position changes. This case once more illustrates that it is essential to understand the geomorphic settings of a coast before attempting to model the large-scale behaviour of these types of coastal systems.

\subsection{Conclusions}

The present study attempted to describe the geomorphic settings of the Banda Aceh coast through the interpretations of the morphological development history using spatial data, historical information and the literature on tectonics, geomorphology and sea-level fluctuation in neighboring regions. The morphological units of the Banda Aceh coast, their forcing factors were identified in this study to determine the geomorphic settings of the modern coastal morphology and the extent of morphological changes due to the earthquake leading to the 2004 tsunami.

This multi-source data analysis combined with literature review to produce a reliable geomorphological interpretation were used to answer the main research question in this study and more detailed formulated questions which are as follows. The main research question of which morphological units can be distinguished at the Banda Aceh coast and how do they response to the earthquake and tsunami (RQ1) has been answered in this study through a cascade model which summarizing the identification of older morphological units that become the boundaries of the modern morphology of theBanda Aceh coast. The Tertiary mountain blocks and multi-level old terraces are the landward boundaries of the current coastal plain. The seaward end of the coastal plain is bounded by a beach ridges belt disected by inlets. The tilting of the base plane that occurred in the Pleistocene has caused different geomorphic settings from the northeastern coast to the southwestern coast. The southwestern coastal plain consists of a flat alluvial plain and convex shoreface profiles developed by alluvial progradation, while the 
northeastern coastal plain consists of beach ridges and swales and concave shoreface profiles influenced by the sea-level regression which developed during the Holocene. More specific questions are answered in the followings.

a) What are the spatial and temporal scales of the different geomorphic units of the Banda Aceh coastal plain and what was the one in particular that determined the development over the past 100 years?

Answer: The geomorphic settings developed during the past Holocene characterized the different morphology of the modern southwestern and northeastern portion of the Banda Aceh coastal plain. These determine the subsequent coastal morphology and sediment composition, thus, strongly influences the morphological development in a decadal time-scale (e.g. 100 years). In general, the modern shoreface of Banda Aceh coast is a sand-poor coastal environment contains only a thin layer of loose sand over a consolidated prograding delta in the Holocene period.

b) To what extent have the earthquake and tsunami of 26 December 2004 affected this coastal system?

Answer: The understanding of the morphological development leads to the geomorphic settings which provide the base to answer this specific research question. In addition to the extensive inundation of seawater to the coastal plain during the tsunami, the impact due to the 2004 earthquake and tsunami also affected the morphological units that have been established in the Holocene period (e.g. the breached old beach ridges and the cropped-out older shoreface deposits). The responses of shoreface profiles to the tsunami waves differed from one profile to another due to different geomorphic settings. The tsunami in combination with tectonic activities has made the coastline of the Banda Aceh to be highly dissected. This shows that such a huge tsunami event occurred only in a very short timescale, but it led to changes in morphology comparable to changes that normally occur on the time-scale of centuries to millennia. The eroded sediments made their contribution as a new deposited layer of the modern coastal morphology that will be imprinted in the geological history of this coast.

This study was aimed to establish the general framework for future research on this specific study location which deserves attention to gain knowledge on the tectono-tsunami process and its impact on the coastal system. Borehole samples and reviews from other studies about this study area incorporated in the analysis in the present study fairly ascertain our interpretations on the geomorphic settings 
inherited from various morphological developments in history. Further study on the stratification of the deposit layers, for instance, by carbon-dating techniques or side-looking radar may be utilized in future to support the overall interpretations of the present study. 


\title{
Chapter 3
}

\section{Short- term morphological response and development of the Banda Aceh coast, Sumatra Island, Indonesia after the tsunami on 26 December 2004}

\author{
Conditionally accepted in Marine Geology, Elsevier
}

\begin{abstract}
The Earthquake and subsequent tsunami of 26 December 2004 have caused a dramatic change in the morphology of the affected coasts bordering the Indian Ocean. Data from different sources and different instants in time used in the present study to investigate the morphological response and development of two coasts that were affected by the tsunami near Banda Aceh city, Sumatra Island, Indonesia (i.e. the northwest and the west coast). The objective is to quantify the initial morphological response and the subsequent development of the coasts revealed by the observed changes in the foreshore zone and the shoreface zone derived from multi-shoreline identifications and Digital Elevation Models (DEMs), respectively.

The stages of recovery process of a coast affected by a tsunami are comparable to that affected by a hurricane; it experienced initial rapid adjustment of the foreshore slope and shoreline undulations, and subsequently followed longer period of shoreface reorganization into a smoother surface. Interestingly, the development of the foreshore zone of the two coasts after 6 months showed opposite trend from their pre-tsunami positions. Ulee Lheue, on the northwest coast, experienced ongoing erosion of about $15 \%$ of the total sediment loss due to the tsunami. The ongoing shoreline retreat at Ulee Lheue in 6 months after the tsunami suggests that the extent of coastal erosion by the tsunami and the lack of sediment supply in the littoral zone after the tsunami could not keep the pace with the sudden change of coastal elevation due to the land subsidence. As a result, the shoreline was retreating even further. At Lampu Uk, on the west coast, $60 \%$ of sediment loss due to the tsunami gained back to the coast after 6 months, and a remarkable pile of sand was accumulated on the backshore after two years since the tsunami. The width and the slope gradient of the shoreface and of the inner shelf as well as the sediment availability and characteristics in front of each coast control this contrasting behaviour.

We argue that after 6 month, the foreshore has asymptotically reached a short-term equilibrium. Moreover, the type of geomorphic settings (e.g. foreshore slope and the shoreface and innershelf width and their geological deposits) and the aftermath sediment characteristics and availability (sand-poor or sand-rich coastal environment) determine the trend of morphological development of the coast after the tsunami.
\end{abstract}




\subsection{Introduction}

Recently, the world experienced a huge natural disaster in the form of the earthquake and tsunami in the Indian Ocean on 26 December 2004. A fault displacement between the Indian oceanic and Eurasian continental plates to the west of Sumatra Island caused a submarine earthquake with a magnitude of $M=9.0$ on the Richter scale (Waltham, 2005; Stein and Okal, 2005). In the following 20 minutes, it triggered huge tsunami waves propagating across the Indian Ocean, destroyed the bordering coastal areas and caused a massive loss of human life in countries bordering the Indian Ocean.

The low-lying city of Banda Aceh on the northern tip of Sumatra was one of the worst affected regions and experienced massive casualties and destruction of property, as it was close (ca. $150 \mathrm{~km}$ ) to the source of the earthquake. The loss of human life recorded was the highest at about two-thirds of the total of 300.000 casualties.

The destructive tsunami waves caused sudden and immense changes in the morphology of the low-lying coast of Banda Aceh. Significant amounts of coastal sediment were scoured, transported and deposited back and forth along the path of tsunami waves, causing immense sediment re-distributions over the entire coast (Narayana et al., 2007; Umitsu et al., 2007; Paris et al., 2007; Jaffe et al., 2006). Tectonic subsidence is suspected to have occurred (Meltzner, et al., 2006; Gibbons and Gelfenbaum, 2005) as a consequence of the earthquake on 26 December 2004 as well as the one on 28 March 2005 (with a magnitude of M=8.0 on the Richter scale).

Studies into the impact of a tsunami on coastal areas have been of interest to scientists for many years. These studies mostly address the analysis of sub-aerial sediment distributions by the tsunami waves (Narayana et al., 2007; Paris et al., 2007 ) in order to reconstruct the tsunami wave flow pattern (Gelfenbaum and Jaffe, 2003) or to examine how landforms affect the tsunami flow (Umitsu et al., 2007). Noda et al. (2007) improved the understanding of the change in offshore sediment characteristics after the tsunami caused by the Tokachi-oki earthquake in Japan in 2003, by using a combined approach of sediment sampling and modelling. At present, estimates of the real-time sediment transport processes during the tsunami of 2004 remain speculative (Paris et al., 2007). Despite these growing interests, there is little discussion on the morphological adjustment and its subsequent development after the tsunami and the combining effect of a land subsidence due to the earthquake. This is mainly due to the lack of available data, such as bathymetry, sediment characteristics or wave climate, especially during the 
tsunami itself. In addition, pre- and post-event data were poorly archived, resulting in a gap of knowledge on the morphological development of the affected coasts.

Sudden and extreme coastal hazard may give significant impact to a coastal area. Morton, et al. (1994) identified four stages of short-term recovery process of the sand-rich Galveston coast on the southeastern Texas, USA after hit by Alicia, a category-3 hurricane. Nevertheless, the impact may also be irreversible (e.g. due to sudden land subsidence or uplift). For instance, Sallenger, et al. (2007) revealed a high degree of shoreline variability (chaotic shoreline) and severely breached barrier islands on the Dauphin Island, Alabama, USA as the immediate impact of the Hurricane Katrina of 2005. We argue that the ability of a coast to recover in a short-term depends on the extent of the impact given by the extreme event to the coastal area. Furthermore, the extent of the impact depends on the geomorphic settings inherited to the coast. Sediment availability and transport in the littoral zone under the wave action eventually determine the feedback and rate of the subsequent morphological development of the coast. In order to attest the abovementioned hypothesis, the present study is aimed to quantify the morphological changes of two coasts near Banda Aceh which have different geomorphic settings that were affected by the 2004 tsunami and tectonic land subsidence, and their subsequent short-term developments. In line with this objective, the following research questions are, therefore, formulated:

RQ2: How has the coast developed after the tsunami so far (i.e., on a relatively short time scale)?

a) What are the magnitude and spatial distribution of the morphological changes due to the tsunami and subsidence?

b) How did the coast with different geomorphic settings develop in the short time after the tsunami?

c) What are the opportunities and the pitfalls of using the multi-source data sets to study the morphological development in a less-investigated study location?

In this study, data such as an aerial-photo mosaic, satellite images, bathymetry and coastal topography at certain points in time before and after the tsunami (i.e. from 2001 to 2007) were used to analyse the-direct-impact of the tsunami and the short-term morphological development of the coasts about two years after the tsunami. All data involved in this study were processed through GIS-based procedures such as geo-referencing, shoreline digitizing, and Digital 
Elevation Model (DEM) generation. In addition, two field visits were conducted in June 2005 and August 2006. Data analysis and interpretation were validated using observations from the two fieldworks and additional information from the literature.

This paper is organized as follows. The characteristics of the study locations, overview of the available data, raw data handling and data uncertainty are described in subchapter 3.2. This is followed by a description of the methods used to analyse the foreshore zone development from the multi-shoreline identifications in Section 3.3. The quantifications of the morphological changes and developments in the shoreface from the DEMs analysis are subsequently presented in Section 3.4. Section 3.5 contains an analysis of the controlling factors on the short-term coastal morphological development. Finally, Section 3.6 draws up the conclusions.

\subsection{Study locations and data overview}

\subsubsection{Study locations}

Banda Aceh is located in the triangular coastal plain at the northwest tip of Sumatra Island, Indonesia. The coastal plain is surrounded by the Indian Ocean on the west coast, the Andaman Sea which is enclosed by small islands in the north, and the Malacca Straits in the northeast (inset of Fig. 1.1). Two study locations were selected (Fig. 3.1 and 3.2): i) Ulee Lheue (pronounced Oolé leu) on the northwest coast, and ii) Lampu Uk (pronounced Lampoo Ook) on the west coast of Banda Aceh. They were selected because the resolution of the available data (either spatially or temporally) is highest in these areas. The lengths of the Ulee Lheue and Lampu Uk sections are about $1 \mathrm{~km}$ and $3 \mathrm{~km}$, respectively.

\section{Ulee Lheue, northwest coast}

The coast of Ulee Lheue has a flat alluvial hinterland which is separated by small shore-parallel lagoon facing a narrow and convex-shape shoreface (see details in Chapter 2). The average elevation of the barrier was about $1.5 \mathrm{~m}$ to $2.0 \mathrm{~m}$ above Mean Low Water Level (MLWL). The beach consists of loose fine sand of $D_{50}=$ $120-140 \mu \mathrm{m}$. Before the tsunami, a one-km seawall was present along Ulee Lheue beach at the northeast side of Krueng Cangkoy river mouth (Fig. 3.1). A short stretch of the beach between the seawall and the ferry port was unprotected by any structures. The beach slope was approximately 1:25 with a significant wave height of $1.0 \mathrm{~m}$ and a period of 4.2 seconds (UP-PSDA, 2003). With these characteristics, 
the surf zone was quite narrow at this location. The beach ridge of Ulee Lheue which area was about 0.5 square $\mathrm{km}$ was a place for densely populated residential areas, local business and municipality which was connected to the Ferry port to and from the Weh Island. Flooding by seawater during the spring tides was the main problem of the coastal community in this location.

Due to the tsunami in 2004, about half-a-km of the beach ridge section was breached by the tsunami, separating the Ulee Lheue village from the Ferry port (Fig. 3.1a) and causing inundation further landward, especially during the high tides. As an immediate protective response, the local authority planned to set up a new seawall for the entire 25-km-long northwest coastal stretch of Banda Aceh. The construction started in 2005 and was half-completed (i.e. from Ulee Lheue to the west part of the Alue Naga Floodway channel) in January 2007.

\section{Lampu Uk, west coast}

The west coast was a white sandy coast of $D_{50}=140-250 \mu \mathrm{m}$. The coastal plain was generally situated higher than $+2.5 \mathrm{~m}$ above MHWL. The beach slope was between 1:30 and 1:50. The area was bordered by coast-parallel ridges and some small headlands. The west coast showed persistent longshore sediment transport from south to north. The significant wave height was about $2.5 \mathrm{~m}$ with a period of 5 seconds (Anonymous, 1997).

Lampu Uk beach is located between a small headland in the north and the Krueng Reba river mouth in the south (Fig. 3.2). An offshore coral reef system existed in the middle of this $3.3-\mathrm{km}$ coastal stretch. A complex of dunes also characterized the pre-tsunami west coast.

The impact of the tsunami on the coastal morphology was revealed by the trim line of the stripped-off vegetation along the foot of the hills and promontories. The shore-parallel dune system along the northern part of the west coast was also cut back; some dunes were flattened and inlet mouths were eroded and widened. A considerable amount of coral reef debris was found at the beach opposite to the still-intact fringing coral reefs (Fig. 3.2). 


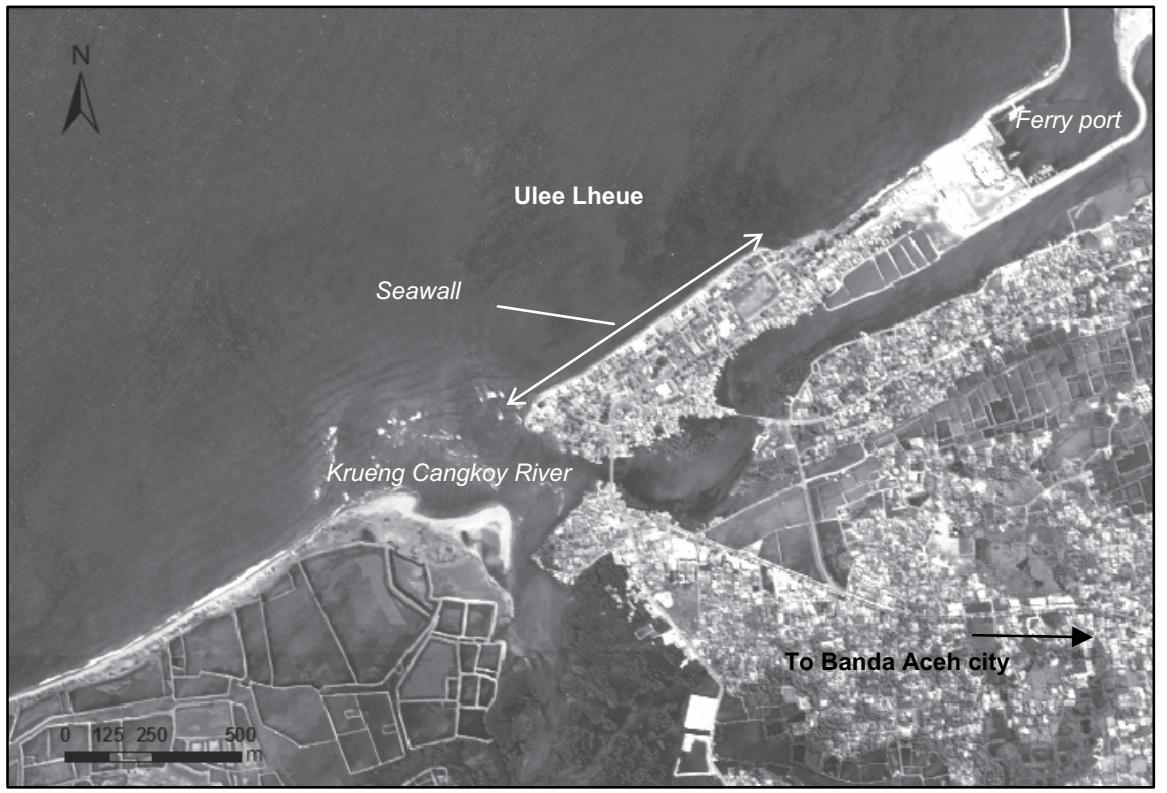

(a)

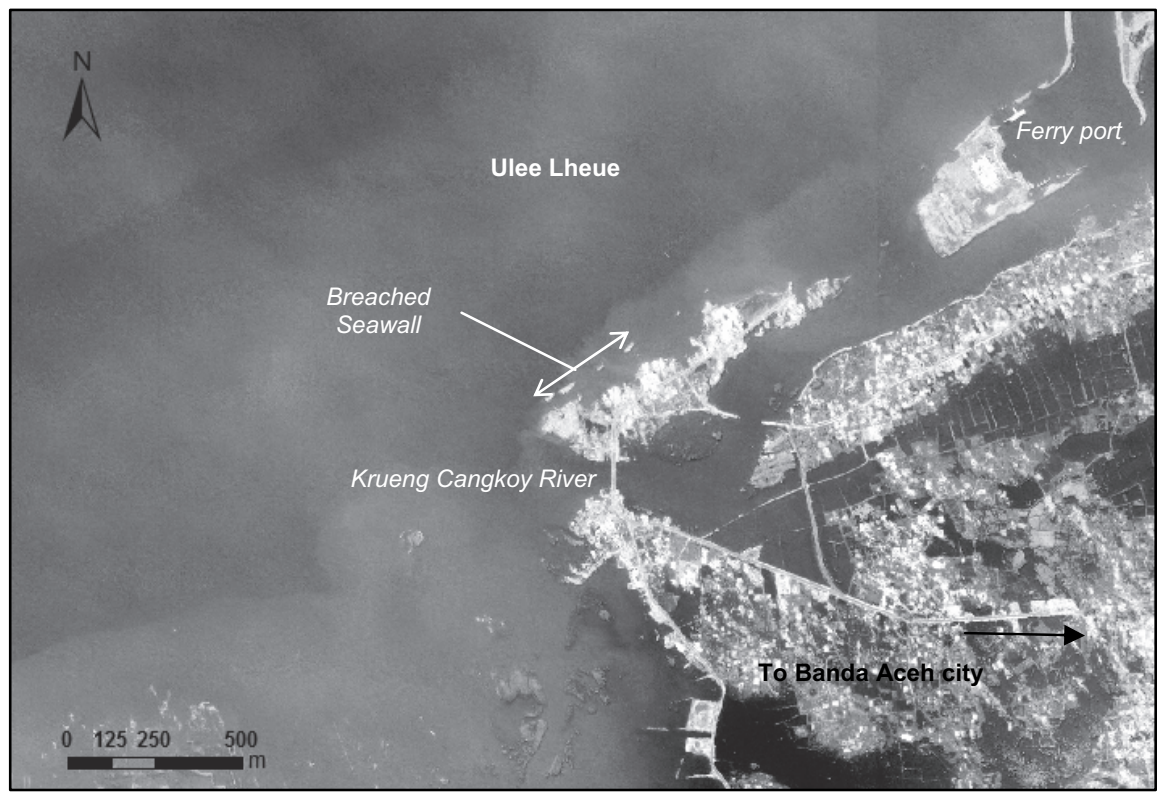

(b)

Figure 3.1: Ulee Lheue at the northwest coast of Banda Aceh. (a) Before the tsunami of December 2004; (b) After the tsunami of December 2004. Data source: IKONOS on 23 June 2004 and 30 December 2004, respectively). Location is depicted in Figure 1.1. 


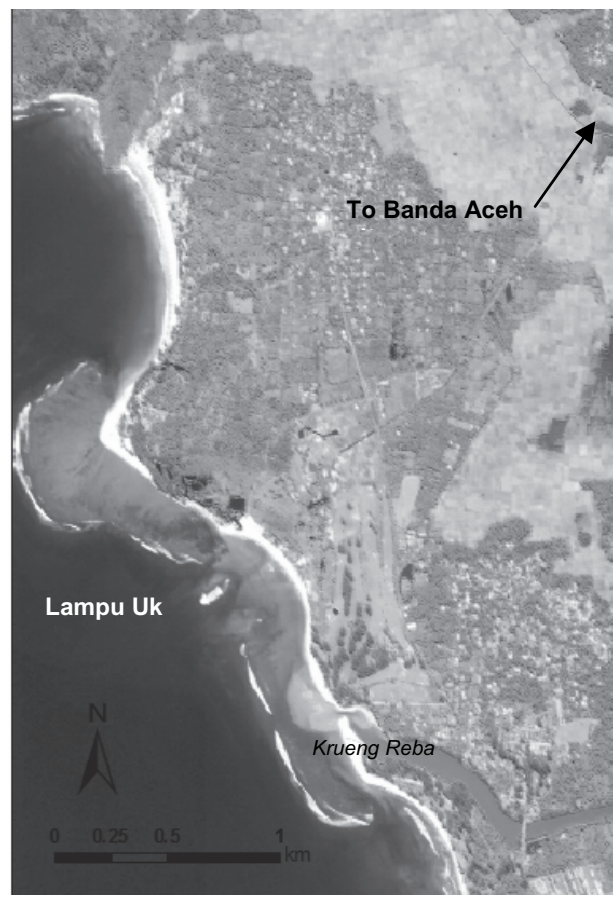

(a)

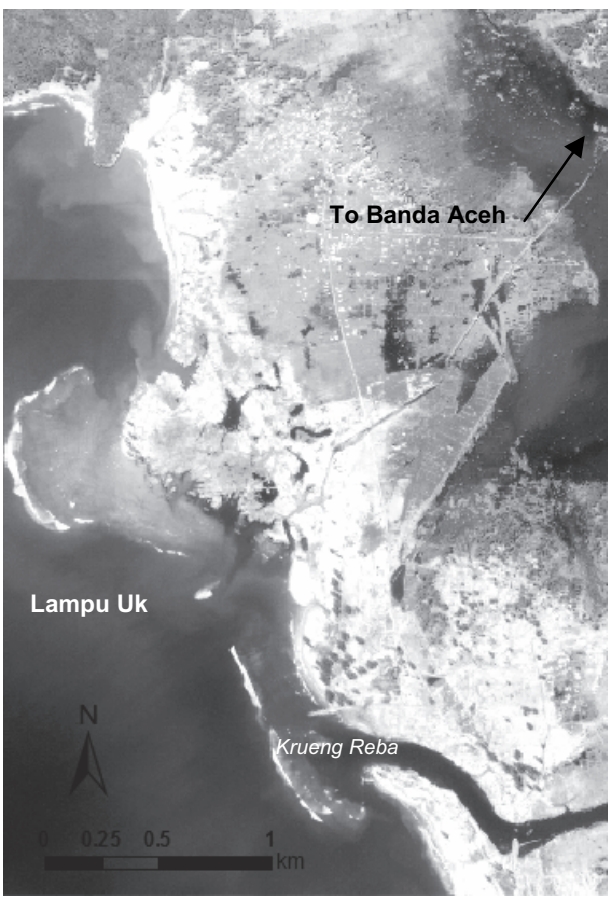

(b)

Figure 3.2: Lampu Uk at the west coast of Banda Aceh. (a) Before the tsunami of December 2004; (b) After the tsunami of December 2004. Data source: QuickBird on 13 January 2002 and 30 December 2004, respectively. Location is depicted in Figure 1.1.

\subsubsection{Data overview}

Monitoring morphological developments requires information about the horizontal and vertical positions of coastal features; e.g. bathymetry, beach elevation, shoreline positions and coastal structures. However, in developing countries, such data are often scarce.

Data sets of different types (e.g. data points, contour lines, feature identifications from images and observational data) were used in this study (Table 3.1). As a result, each data set has a different character and quality. Aerial photos and satellite images are the main data sources used to identify shoreline changes and development. A mosaic of ortho-rectified aerial-photo mosaic of Banda Aceh has the highest spatial resolution. The aerial photos were obtained nearly six months after the tsunami (i.e. 6 June 2005). The mosaic was resampled to a high 
spatial resolution raster image of $0.3 \mathrm{~m}$ pixel size. This map was used as the basemap for geo-referencing the other maps and satellite images being used for this study. The geo-reference details of the surveyed data are all transformed to the UTM zone 46N and WGS 1984 ellipsoid datum.

Table 3.1: Available data sources and their acquisitions

\begin{tabular}{|c|c|c|c|c|c|}
\hline \multicolumn{2}{|c|}{ Image Data } & Date & $\begin{array}{l}\text { Local Time } \\
(\mathrm{hr} / \mathrm{mn} / \mathrm{sc})\end{array}$ & $\begin{array}{l}\left.\text { Tidal Elevation }{ }^{6}\right) \\
\qquad(\mathrm{m})\end{array}$ & $\begin{array}{c}\text { Spatial } \\
\text { Resolution } \\
(\mathrm{m})\end{array}$ \\
\hline \multicolumn{2}{|c|}{ Bathymetry 1) } & April 2001 & $\mathrm{~N} / \mathrm{A}$ & $\mathrm{N} / \mathrm{A}$ & 0.5 (vertical) \\
\hline \multirow{3}{*}{$\begin{array}{l}\text { Satellite } \\
\text { Image }\end{array}$} & $\begin{array}{c}\text { West } \\
\text { (Quickbird) }\end{array}$ & 13 Jan 2002 & 11:12:39 & 0.7 (MLWL) & 2.5 \\
\hline & $\begin{array}{l}\text { Northwest } \\
\text { (IKONOS) }\end{array}$ & 23 Jun 2004 & 10:54:29 & 0.5 (MLWL) & 2.5 \\
\hline & $\begin{array}{c}\text { West \& } \\
\text { northwest } \\
\text { (IKONOS) }\end{array}$ & 30 Dec 2004 & 10:55:41 & $\begin{array}{c}1.2 \text { (1 hr. before } \\
\text { MHWL })\end{array}$ & 2.5 \\
\hline \multicolumn{2}{|c|}{$\begin{array}{c}\text { Ortho-rectified aerial } \\
\text { photo mosaic }{ }^{3)}\end{array}$} & 06 Jun 2005 & Ca. 08:30:00 & 1.5 (MHWL) & 0.3 (basemap) \\
\hline \multicolumn{2}{|c|}{$\begin{array}{l}\text { Coastal topography } \\
\text { map }^{4)}\end{array}$} & 06 Jun 2005 & Ca. $08: 30: 00$ & 1.5 (MHWL) & 0.5 (vertical) \\
\hline \multicolumn{2}{|c|}{ Bathymetry $2^{5)}$} & Jan 2006 & $\mathrm{~N} / \mathrm{A}$ & $\mathrm{N} / \mathrm{A}$ & 0.5 (vertical) \\
\hline \multicolumn{2}{|c|}{ Bathymetry 35) } & Jan 2007 & $\mathrm{~N} / \mathrm{A}$ & $\mathrm{N} / \mathrm{A}$ & 0.5 (vertical) \\
\hline
\end{tabular}

Data source:

1) Research Unit for Water Resources (UP-PSDA) of Syiah Kuala University in Banda Aceh

2) International Institute for Geo-information Science and Earth Observations (ITC) in Enschede, The Netherlands

3) From an airborne survey conducted by the Norwegian Agency for Development Cooperation (NORAD) on behalf of the Survey and Mapping Agency of Indonesia (Bakosurtanal).

4) Topographic contour derived from the basemap (3) by Japan International Cooperation Agency (JICA)

5) Bureau of Rehabilitation and Reconstruction of Aceh and Nias (BRR Aceh-Nias)

6) Tidal charts were obtained from the Hydro-Oceanographic Service of Indonesian Navy

The multi-spectral IKONOS satellite images consist of three bands. The images were resampled to a spatial resolution of $2.5 \mathrm{~m}$ and then enhanced to improve the appearance of discernible coastal features. In this case, a user-defined 
type of stretching for the three image bands was used. A coastal topographic contour map of Banda Aceh city was derived from the ortho-rectified aerial photos (i.e. the base map) through a photogrammetric process. The contour line interval is $0.5 \mathrm{~m}$, which facilitates a careful study of new developments along the coast.

Note that the bathymetric and coastal topographic data sets were only available for the upper shoreface zone from the three sets of surveys in 2001, 2006 and 2007 (Table 3.1), and they cover only the northwest coast of Banda Aceh (i.e. Ulee Lheue). Therefore, analysis of coastal changes and development were focused on this particular zone. In addition, to utilize the images to delineate shorelines, the tidal stages at which the images were acquired must be known. The only available source for tides fluctuation in this region was the hourly tidal-chart predictions released by the Hydro-Oceanographic Service of Indonesian Navy.

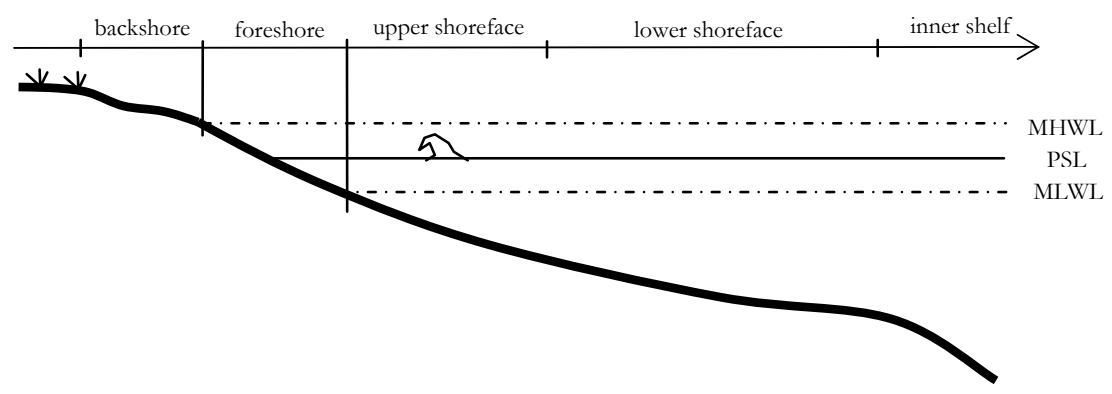

Figure 3.3: Schematized spatial extent of the shore-normal coastal profile used in this study, adapted from Short (1999).

With regard to the spatial extent, the shore-normal coastal profile was divided into the lower shoreface, upper shoreface, foreshore zone and backshore zone (Fig. 3.3). All the elevation data references were transformed such that they became relative to the MLWL datum (where MLWL $= \pm 0.00 \mathrm{~m}$ ).

\subsubsection{Raw data handling}

Handling the raw data sets with different spatial and temporal dimensions constituted some challenges. To some extent, the procedure used to make the data compatible influences the methodology applied in this study. 


\subsubsection{Dealing with spatial resolution difference and data gaps}

High-resolution satellite images are typically expensive and only cover a small area. Consequently, the data with the smallest coverage determine the spatial extent of the study locations. For instance, only the Ulee Lheue beach ridge could be included in the study location of the northwest coast because the coastal topographic data and the available IKONOS satellite images only cover this area.

In order to generate a DEM, coastal topographic and bathymetric point data had to be integrated. Data gaps between coastal topography and bathymetry are common in this case and we therefore had to estimate elevation values to fill in these gaps. This was done by manual adjustments of bathymetric contours in the vicinity of a complicated coastal morphological feature.

\subsubsection{Data uncertainty}

Several uncertainties and errors may be present in the data. Vertical and horizontal errors in a bathymetric survey may originate from the equipment being used, i.e. due to the limited vertical accuracy of an echo sounder and the limitations of horizontal positioning equipment such as conventional geodetic equipment (e.g. theodolite and level), or GPS. To estimate these deviations, the high-resolution base map was used to fix the position of the surveyed data (i. e. bathymetry and coastal topography).

In the raw data for the bathymetry of 2006, we observed a linear shift of the horizontal position relative to the base map. This could be corrected by applying a simple horizontal coordinate transformation. The 2007 data positions of the surveyed points had already been geometrically fixed. On the other hand, a slight rotational effect (about 10 degrees due north) as compared with the overall position of the 2001 data was found. This problem was subsequently fixed by a rotation transformation operation.

Another data error to be accounted is the vertical error. For 2001, the vertical uncertainty is associated with the accuracy of the echo sounder (i.e. \pm 0.1 $\mathrm{m})$ and the error on the level reading (i.e. estimated to be $\pm 0.1 \mathrm{~m}$ ). The Standard Root-Mean-Square Error (RMSE) procedure was used to calculate the overall vertical uncertainty, e.g. as applied also by Rosati (2005) and Zhang et al. (2005) for similar sources of error. Hence, the RMSE of the vertical uncertainties is $\pm 0.14 \mathrm{~m}$. The other two bathymetric data sets have an estimated uncertainty of $\pm 0.1 \mathrm{~m}$, which is mainly that associated with the accuracy of the echo sounder. 
For this study, a DEM was generated using the Triangulation Irregular Network (TIN) method. The TIN is an interpolation method which facilitates integration of several data types, for example, a segment (contour) map combined with a point elevation map. The result of this process is a surface map configured by the triangular nodes obtained from the interpolation process. The first DEM generation may yield unreliable contours at a certain location during the interpolation. Therefore, an adjustment process had to be carried out subsequently. The degree of reliability depends very much on the data density. The greater the distance between one data point and another, the larger the uncertainty.

\subsubsection{Observations on land subsidence}

Field observations were considered to be complementary yet essential in this study. The reasons for these field observations were first, to provide more evidence and ground truth to support the investigation results from the overall data analysis. Second, the morphology of the coast has been highly modified during the periods of observation which makes it difficult to detect any consistent vertical changes due to land subsidence. We expected that a priori information about the land subsidence from field observations would contribute to a better analysis of development of the observed coastal morphology.

Apart from collecting bathymetry, topography and satellite images, two field visits in June 2005 and August 2006 were conducted to observe the development of the coast after the tsunami and to find evidence of land subsidence along the west and the northwest coast of Banda Aceh. In addition, information collected from some other studies complements the observations.

\subsection{Foreshore development study}

This section presents the analysis of shoreline identification to quantify the changes and developments of the coastal morphology. The idea was to observe the coastal morphological response and short-term development (6 months) due to the earthquake and tsunami of the two coasts, which have different morphological characteristics.

\subsubsection{Multi-shoreline identification}

Identification of a 'shoreline' on the beach that is a repeatable, consistent, and meaningful indicator of sediment transport on the foreshore throughout time 
invites new interest and debate in the coastal scientific community (e.g. Farris and List, 2007; Moore, et al. 2006; Boak and Turner, 2005; and Ruggiero, et al. 2003), particularly since high-resolution satellite images and aerial photographs are increasingly utilized.

Two methods of identifying a 'shoreline' are defined by Moore, et al. (2006); the visually proxy-based and the datum-based shoreline identifications. The visually proxy-based method typically identifies the landward extent of the last high tide and is recognized as a tonal contrast between the wet intertidal beach and the dry supratidal beach (Morton, 1979; Dolan and Hayden, 1978; Stafford, 1971). Applying this method on the low resolution satellite images or topographic maps results merely a single shoreline. On the other hand, the usage of high-resolution images and aerial photo in this study enable the identification of multiple shorelines. The multiple shoreline definitions were adapted from the study by Boak and Turner (2005):

1) Saturation line, the border of the area which is saturated by groundwater (a similar feature was termed 'groundwater exit point' by Boak and Turner, 2005). The sand colour of this area is dark grey or dark brown, depending on the type of beach material.

2) Light saturation line, the border line of the previous run-up, which has less groundwater content than that of the saturation line. This is equal to MHWL in this study, which adapted the definition of the previous high tide water level by Boak and Turner (2005).

3) Water line, the border line of the instantaneous water body, which appears in green or blue.

4) Land-visible line, the border line of the water body where the submerged land just below the water is still visible.

The datum-based shoreline is derived from topographic surveys (List and Farris, 1999; Ruggiero et al., 2003; Smith and Zarillo, 1990) or laser altimetry data are based on the cross-shore position of an elevation contour extracted from topographic. We combined this method in this study to be able to determine the elevations of the multiple shorelines which initially have no elevation information from the satellite images. Thus, a coastal topographic map (Table 31.) was used to give approximate elevation to the multiple shorelines, which actually created contours of the foreshore morphology. The contour map used the Mean Low Water Level (MLWL) as the datum reference. A tidal chart associated with the time 
at which the satellite image was acquired was used to validate the water level position in that image (schematized procedure in Fig. 3.4).

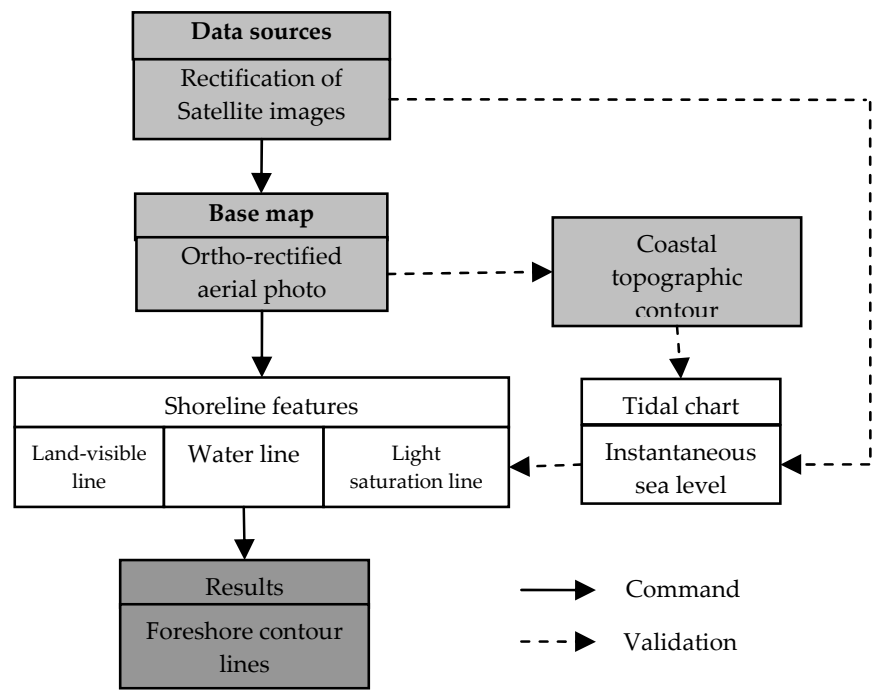

Figure 3.4: Scheme of data source usage for multi-shoreline identification and its validation.

As an example of this procedure, Figure 3.5a shows the identified shorelines of the Lampu Uk foreshore (between profiles P1 and P2 in Fig. 3.8). Similar identification was carried out in Figure $3.5 \mathrm{~b}$ which shows that the contour of +1.5 $m$ coincided with the landward edge of the light saturation zone, which was therefore determined as the light saturation line. The tidal chart confirmed this elevation of $+1.5 \mathrm{~m}$ as well, which was actually the Mean High Water Level (MHWL) position of the tidal range. This led to the first estimate that the light saturation line appeared in the particular satellite image can be identified as MHWL. Knowing that the +1.5 m-contour corresponds to MHWL, the other contour lines from the coastal topographic map can be used to estimate the other coastal features' elevations.

Hence, from the four shoreline features, there were only three that could be used to estimate elevation: i) the light saturation line (elevation $+1.5 \mathrm{~m}$ ); ii) the water line (elevation $+1.0 \mathrm{~m}$ ); and iii) the land-visible line (elevation $+0.5 \mathrm{~m}$ ). From these data, the shoreline position as well as the steepness of the foreshore slope change over time can be observed. Having the positions of the $+0.5,+1.0$ and 
$+1.5 \mathrm{~m}$ contours, it was assumed that the position of the $\pm 0.00 \mathrm{~m}$ contour line can be obtained by extending the slope of the foreshore.

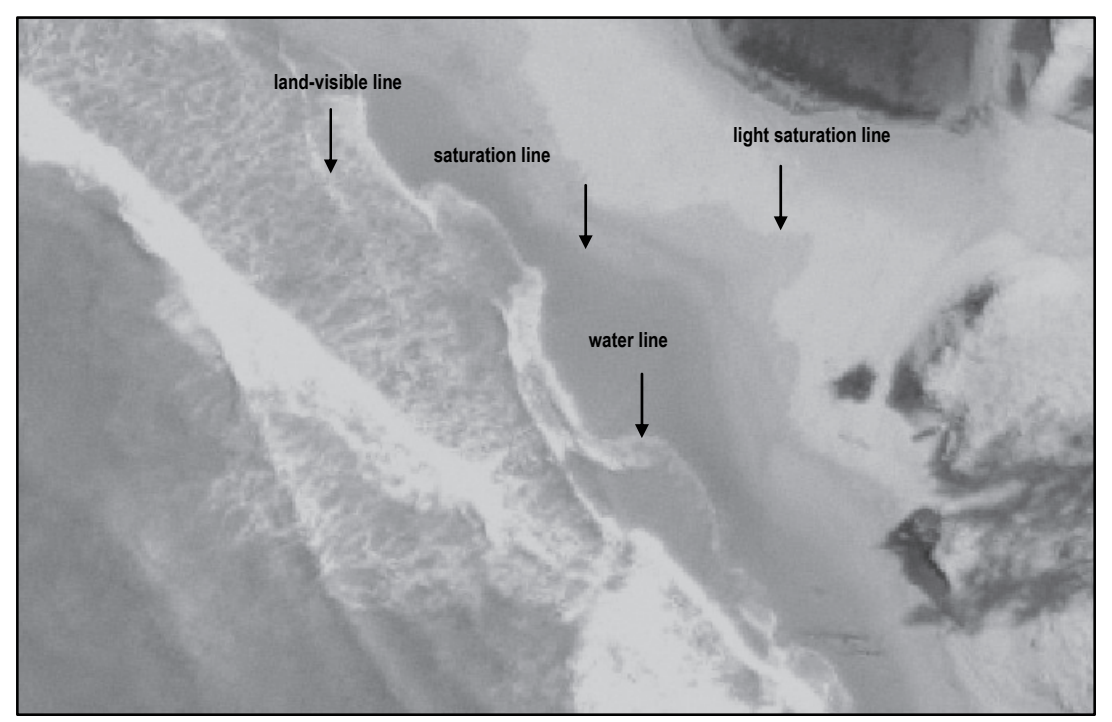

(a)

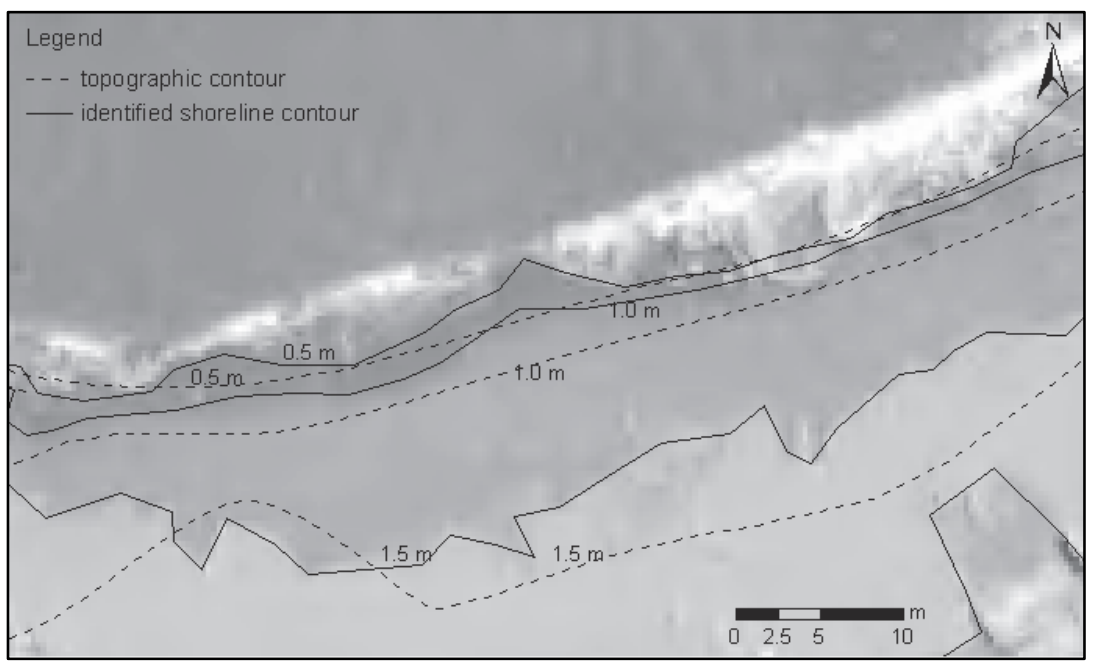

(b)

Figure 3.5: Identification of shorelines. (a) Shoreline features. (b) Identified shoreline features in June 2005 based on the contour map and discernible features, validated by the tidal chart. 
To check the consistency of this procedure, the aerial photo mosaic and the other satellite images of the coastal stretches with a gentler beach slope (wider beach) along the northwest and west coasts were examined in the same way. It appeared that even though the colour tones of the coasts may be quite different, the shoreline features were similarly discernible. As a matter of fact, each image that was acquired at a different tidal stage helps to improve the elevation of shoreline approximation.

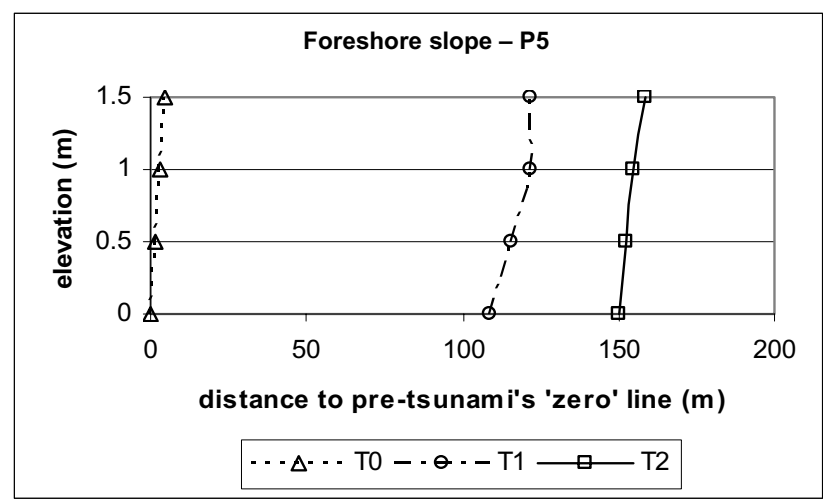

(a)

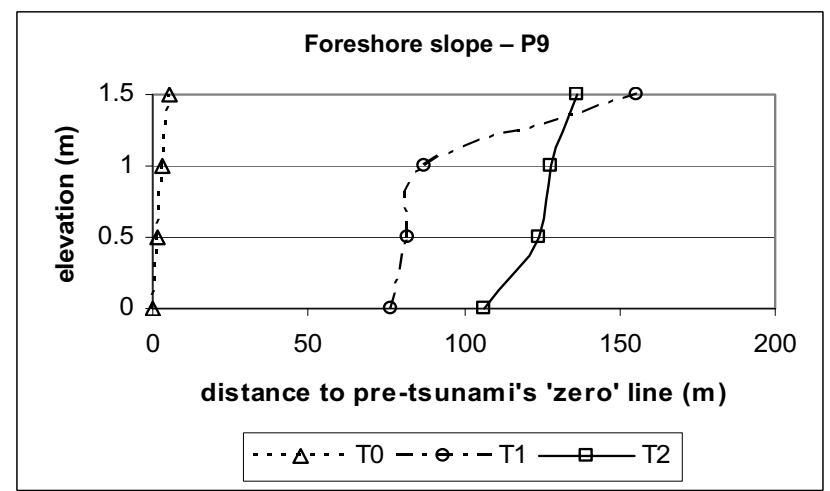

(b)

Figure 3.6: Examples of foreshore slope of early and 6 months after the tsunami at Ulee Lheue Beach (profiles are depicted in Fig. 3.7a). Note: T0 $=23$ June 2004, i.e. before the tsunami; $\mathrm{T} 1=30$ December 2004, i.e. 4 days after the tsunami; T2 $=6$ June 2005, i.e. 6 months after the tsunami. 


\subsubsection{Quantification of sediment volume changes in the foreshore zone}

Changes of shoreline position between images from different points in time show visually the impact and the development of the coastal morphology since the tsunami. The subsequent step was to quantify the magnitude of those changes. A simple volumetric control principle was adopted to calculate the amount of sediment loss or gain from two consecutive coastal profiles. Figures 3.6a and 3.6b show the foreshore profiles (derived from the elevations of the shoreline features) for two locations at 3 instants in time.

The pre-tsunami $0.00 \mathrm{~m}$-contour position was used as the reference to measure the distance between the consecutive shoreline positions (i.e. T1-T0 and T2-TO in Fig. 3.6a and 3.6b). The distances between the pre- and the early posttsunami profiles $(T 1-T O)$ and between the pre- and 6 months post-tsunami profiles (T2-TO) were determined to calculate the volume of sediment erosion/deposition in $\mathrm{m}^{3}$. Subsequently, the difference between the two calculated volumes determines the volume change due to the morphological development in the foreshore zone since the tsunami (T2-T1).

\section{Ulee Lheue, northwest coast}

Satellite images acquired directly after the tsunami display severe coastline retreat at Ulee Lheue as a direct impact of tsunami waves and/or subsidence. The images show the presence of a chaotic shoreline, a destroyed seawall and a severely eroded and breached beach ridge (Fig. 3.1b). Most of the profiles along the Ulee Lheue foreshore revealed significant erosion (i.e. T0-T1 in Fig. 3.7).

In the first 6 months after the tsunami, the new surf zone (recognized by the position of the breaking-wave line) was reshaped. The shoreline became less undulating, and the foreshore zone tended to shift landward. Littoral sediment appeared to have been re-distributed alongshore, as revealed by the accretion at profiles P4 and P6, and the smoothened edge of pointed remnants (between P7 and P8) adjacent to them (see shoreline positions in Fig. 3.7). The remnants of the breached beach ridge such as those between P9 and P11 started to re-connect by the building up of new beaches from fresh sediment deposits to a level comparable to MHWL (+1.5 m). 


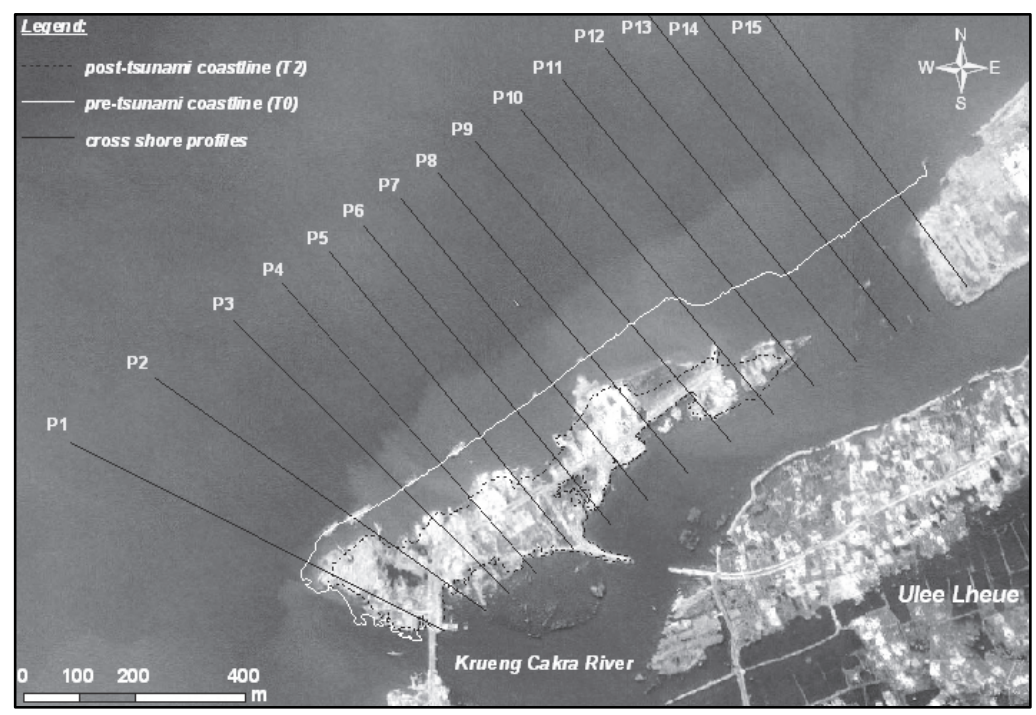

(a)

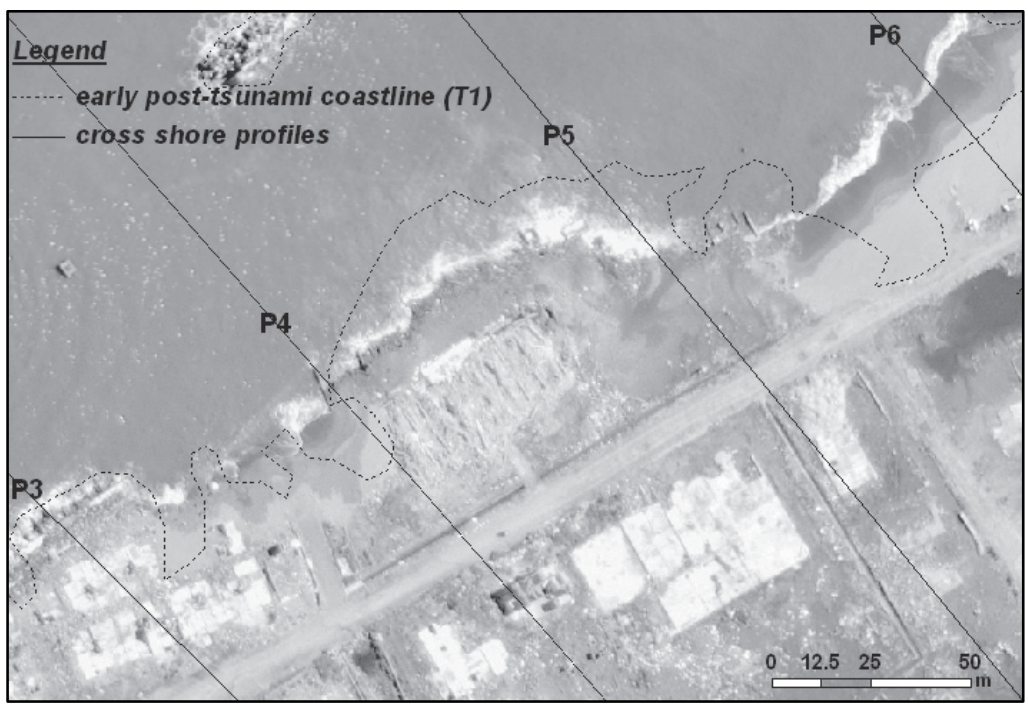

(b)

Figure 3.7: Examples of shoreline contours $(+0.5 \mathrm{~m})$ and sediment volume changes at Ulee Lheue beach. (a) The background image showing the situation directly after the tsunami (T1). The development after 6 months is shown by the black dashed line; (b) The background image shows the situation 6 months after the tsunami (T2) which reveals a new surf zone with apparent breaking wave pattern. On top of that, the dashed line represents the shoreline directly after the tsunami (T1). Image sources details are in Figure 3.6 and Table 3.1. 


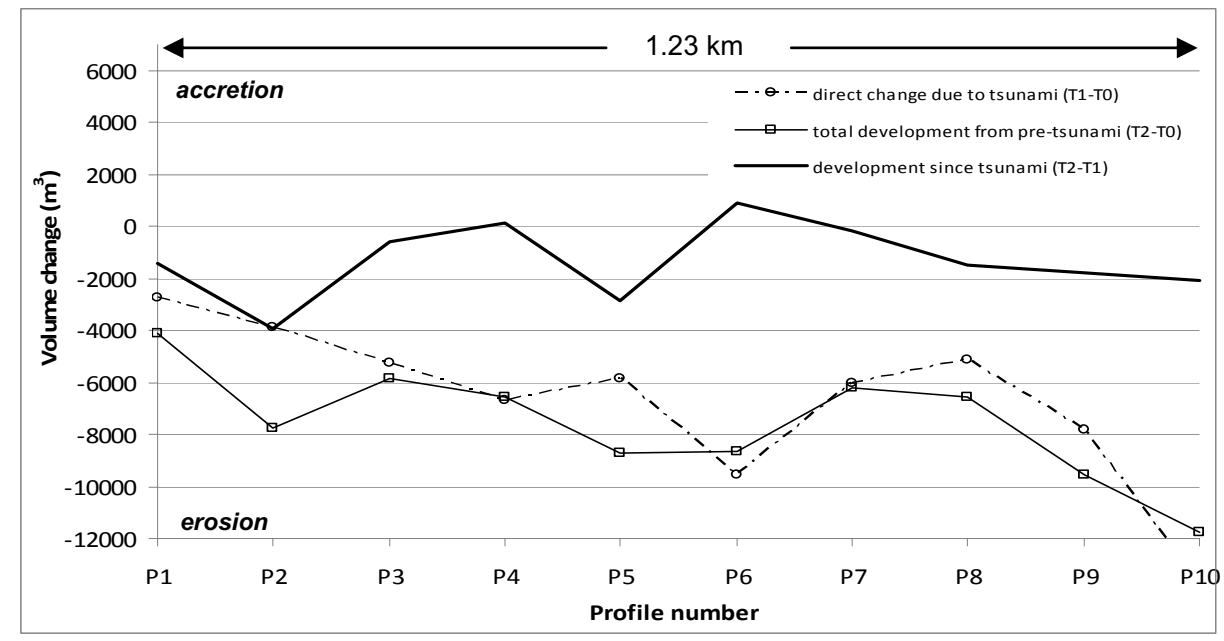

Figure 3.8: Sediment volume change along the Ulee Lheue coast. Note: $T 0=23$ June 2004; T1 = 30 December 2004; T2 = 6 June 2005.

As a result of the tsunami, the shorelines retreated on average about $73 \mathrm{~m}$ from the pre-tsunami position. This is comparable to a total volume of sediment loss in the initial response to the tsunami (T1-T0 in Fig. 3.8) of $1.3 \times 10^{5} \mathrm{~m}^{3}$. In the following 6 months, or two months after the second big earthquake in March 2005, the shoreline continued to retreat, resulting in an average distance of $84 \mathrm{~m}$ from the pre-tsunami shoreline. This is comparable to the amount of a total volume of sediment loss of $1.5 \times 10^{5} \mathrm{~m}^{3}$ (i.e. TO-T2 in Fig. 3.8). This implies that ongoing retreat occurred during the 6-month development, which equals about $15 \%\left(1.9 \times 104 \mathrm{~m}^{3}\right)$ of the sediment loss due to the tsunami (i.e. T2-T1 in Fig. 3.8).

\section{Lampu Uk, west coast}

The morphological response to the tsunami on the west coast, represented by Lampu Uk beach, was similar to the northwest coast, i.e. chaotic shorelines. Beach scouring by the strong waves created depressions, which were commonly found along the coast (i.e. inland water bodies in the vicinity of profile P8-P10 and P19P20 in Fig. 3.9). 


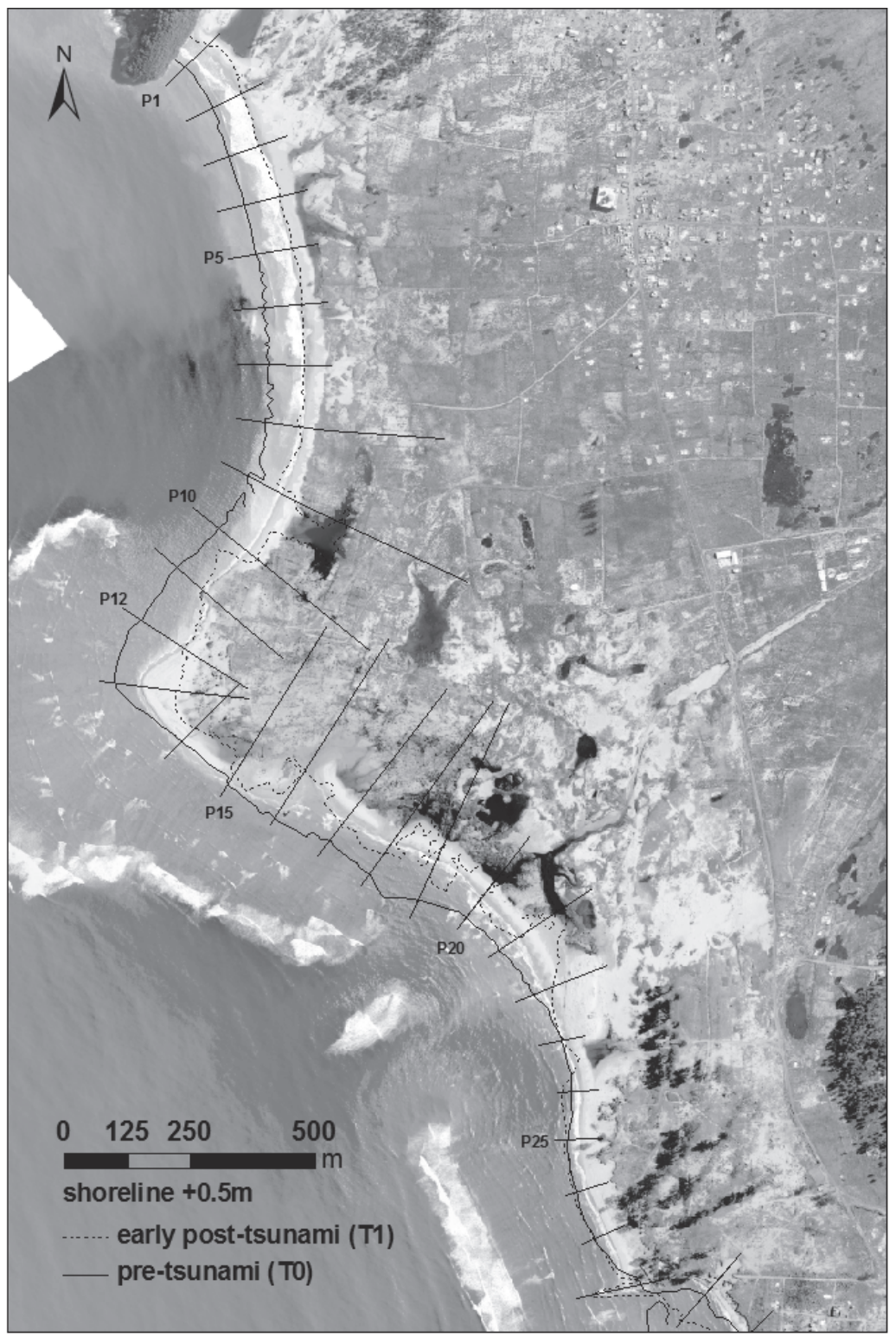

Figure 3.9: Examples of shoreline changes (contour $+0.5 \mathrm{~m}$ ) and sediment volume changes at Lampu Uk. The background ortho-rectified aerial photo shows the development of the coast in June 2005 (6 months after the tsunami). 
The Lampu Uk shoreline along profiles P1 to P21 significantly retreated on average as far as $77 \mathrm{~m}$ landward from the pre-tsunami's shoreline, while the adjacent part, i.e. P22-P27, retreated less. The coastal section P1-P21 was a nonprotected sandy beach with a gentle slope, while the adjacent coastal section in the south was a beach with dune formation with a maximum elevation of ca. $10 \mathrm{~m}$ above MLWL. Coastal protection structures such as the beach revetment along profile P25 to P27 may have helped the southern coastal section survive the tsunami. As a matter of fact, during the field visit in May 2005, we observed that the she-oak trees (Casuarina equisetifolia) behind this section survived the tsunami, and the beach revetment in front of them was still intact.

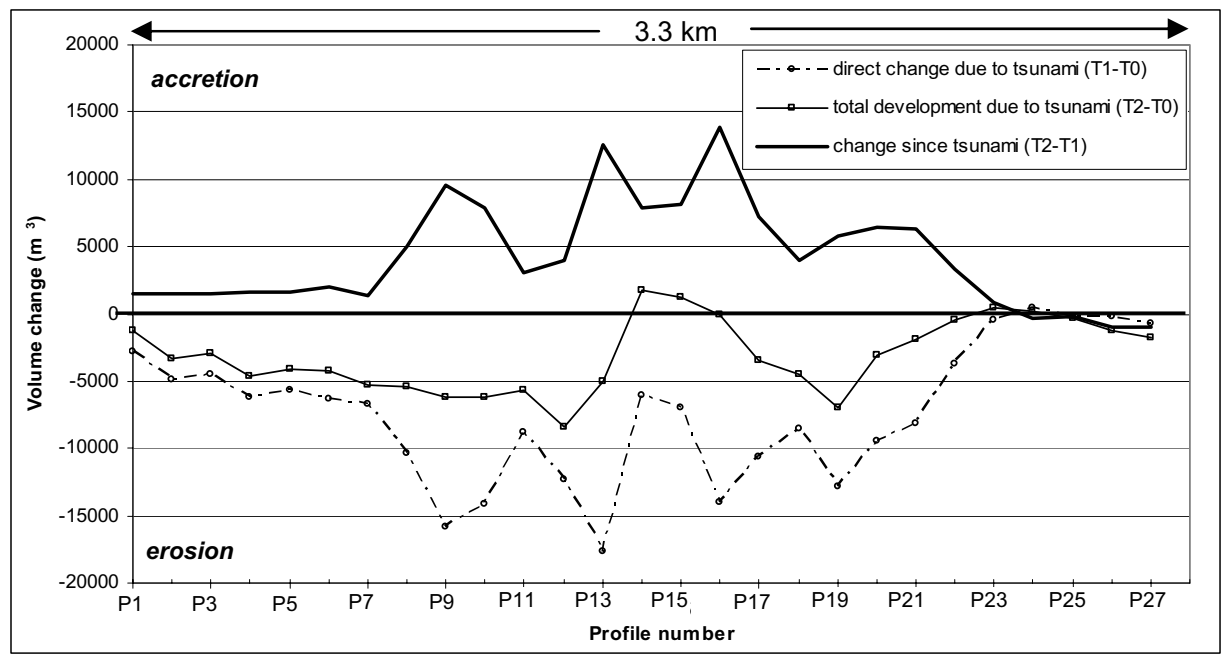

Figure 3.10: Sediment volume change along the foreshore zone. Note: $T 0=13$ January 2003; T1 = 30 December 2004; T2 = 6 June 2005.

In the 6 months after the tsunami, the Lampu Uk shoreline significantly advanced seaward along the entire north part (P1-P21), which contrasted with a slightly retreating shoreline further south (P22-P27). This accretion phenomenon was considerably different from what has occurred on the northwest coastal section (Ulee Lheue).

Small inlets of profiles P8 and P10 used to be inland depressions behind the sandy beach in pre-tsunami times. As a result of the tsunami, the beach in front of them was breached and this connected the depressions to the sea. The beach in the vicinity was also flattened and massive coral reef debris was dumped on the beach, 
which likely originated from the fringing coral reef complex in front of the small promontory (profile P10-P20). The development of the promontory showed a significant beach growth orientated northwards, suggesting the prevailing direction of the longshore sediment transport of this region. A newly formed inlet between profile P16 and P17 remained open, indicating that the waves or tidal currents were strong enough to prevent the inlet from closing, even though the adjacent beach kept accreting.

The total amount of sediment loss due to the tsunami and the sediment gain during the subsequent development were $2.0 \times 10^{5} \mathrm{~m}^{3}$ and $0.8 \times 10^{5} \mathrm{~m}^{3}$, respectively. This means that $1.1 \times 10^{5} \mathrm{~m}^{3}$ or about $60 \%$ of the sediment loss due to the tsunami was gained back into the beach stretch within 6 months.

\subsection{Digital Elevation Models (DEMs) of shoreface development at Ulee Lheue}

Up to this point, the quantification of morphological development of the foreshore zone has given an idea of how much sediment exchange took place in the foreshore zone in the short period since the earthquake and tsunami. In this section, the study is expanded to a larger area of coastal zone, covering the shoreface, foreshore and backshore at Ulee Lheue. Three-dimensional morphological changes and developments were studied by using coastal profiles normal to the coastline. The morphological pattern development over time can be determined from changes in elevation of two consecutive coastal profiles, i.e. 2001-2006 and 2006-2007, shown in Figure 3.6b. Sediment volume changes (i.e. erosion, deposition and net change) are also quantified in this section.

\subsubsection{Input data and methods}

Different data sources, in terms of topography and bathymetry, were compiled as input to generate a DEM. In this study, three sets of bathymetric-topographic integrated data sets were used: i) pre-tsunami data of April 2001; ii) one year posttsunami data of January 2006; iii) two-year post-tsunami data of January 2007 (see also Table 3.1). The bathymetry of 2006 and 2007, measured during the month of January of the corresponding year, gave an opportunity to observe seasonal morphological development after a full cycle of monsoonal climate.

After generating the initial DEM, a contour line map with a $0.5 \mathrm{~m}$ contour interval was extracted. The data set of January 2006 has a significant gap at the 
water-to-land boundary (foreshore zone). Hence, to obtain a realistic DEM, the gaps between the data had to be filled in to overcome the erratic interpolation. It was described in Chapter 2 of this thesis that, this particular section of the northwest coast of Banda Aceh is typically a sand-poor environment and is not significantly influenced by the sediment supply from a river. The recovery process after the tsunami in the littoral zone was, therefore, influenced only by the reorganization of the shoreline by littoral transpot which initially was highly modified (chaotic) by the tsunami waves. As was observed, the shoreline becomes more regular by June 2005, suggesting that from this point on the recovery process might have been slowed down towards a seasonal equilibrium. Since seasonal change was not important in this particular coastal section (personal communication with Dr. Wong Poh Poh), we assumed that the foreshore morphology from June 2005 until January 2006 did not change considerably.

\subsubsection{Morphological development of the shoreface}

Figure 3.7 shows the results of DEMs generation from three consecutive data of pre-tsunami (2001), one-year post-tsunami (2006) and two-year post-tsunami (2007). The colour gradation from red to blue represents the sub-aerial to subaqueous part of the coastal area. Unfortunately, the shoreface bathymetry immediately after the tsunami (e.g. 30 December 2004) was not possible to obtain within the equal area coverage, providing the chaotic situation. However, the impression given by shoreline position and shape of the early after tsunami (December 2004) was significantly different to those of the 6 months after (June 2005) in subsection 3.4.1. This may be used as a consideration to roughly have an idea of the degree of the shoreface morphology irregularity expected to occur immediately after the tsunami.

The shoreface at profile P1 consisted of a set of submerged ebb-tide delta lobes deflected seaward at the northeast side of the Krueng Cangkoy river mouth (see DEM 2001 in Fig. 3.11). Furthermore, the data show a trench complex, situated in the middle of the coastal section (between P5 to P7 in Fig. 3.7a or the dark blue portion near P5 of DEM 2001 in Fig. 3.11a). A gentle shoreface profile was observed in the northeast section (P10 to P15) which used to be an open beach. The shoal across profile P1 existed since the past century after the southwest-end portion of the beach ridge was breached in early 1900s (see Chapter 4). 


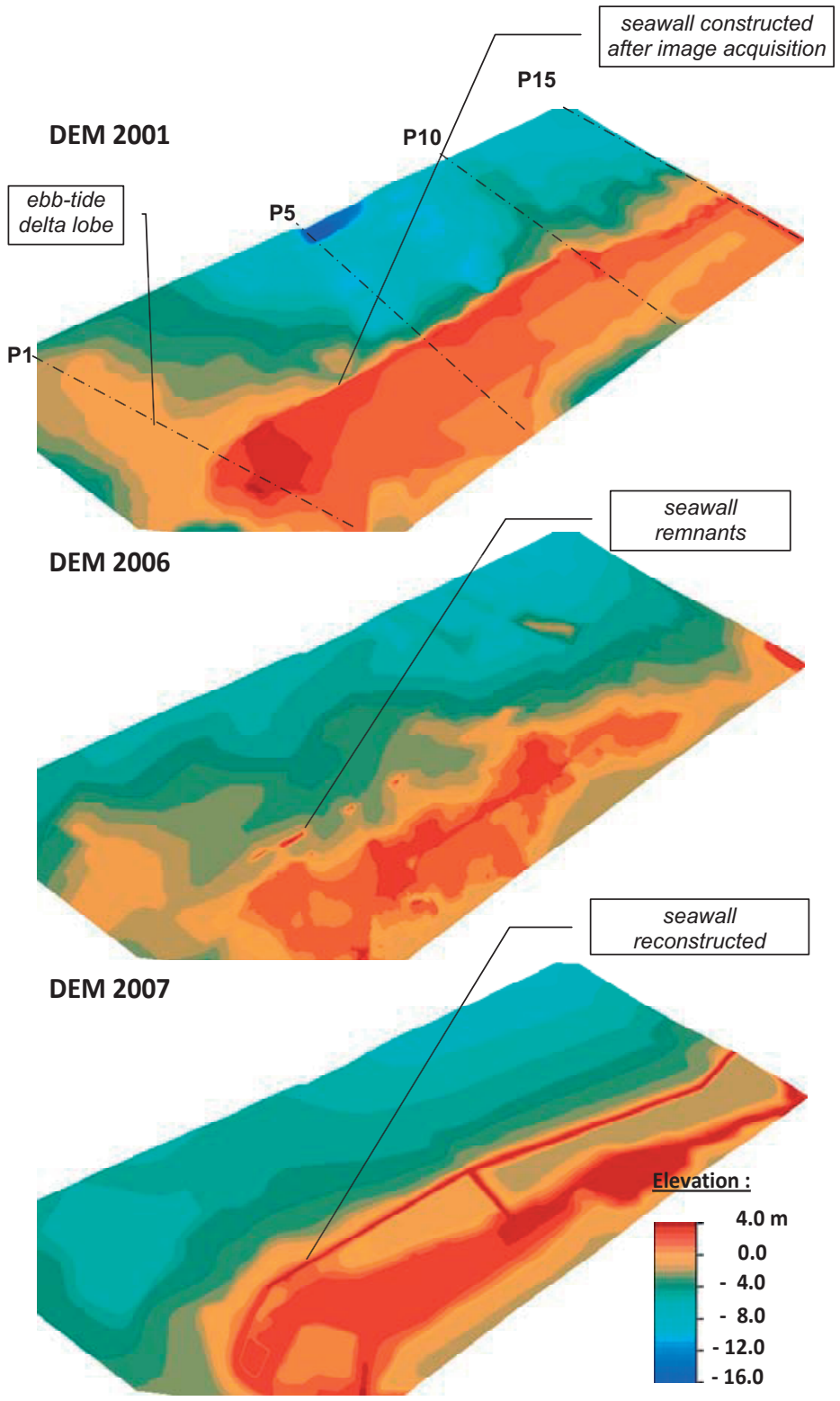

Figure 3.11: Generated DEMs of Ulee Lheue coast derived from bathymetric measurements data of 2001, 2006 and 2007. 


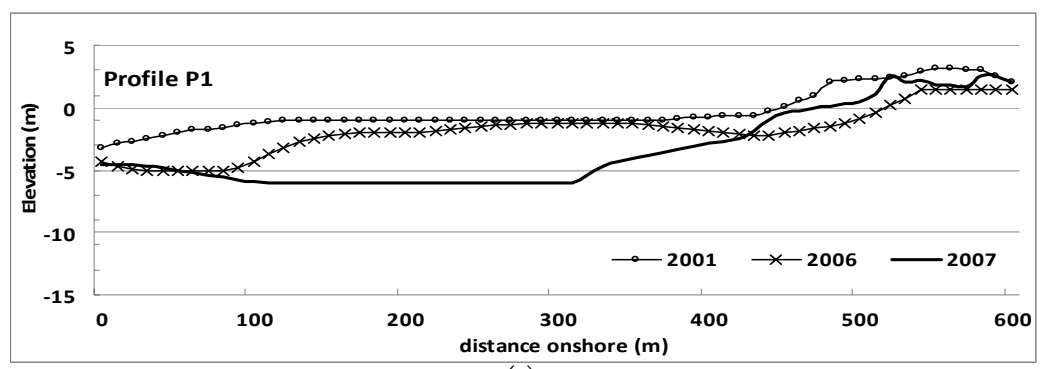

(a)

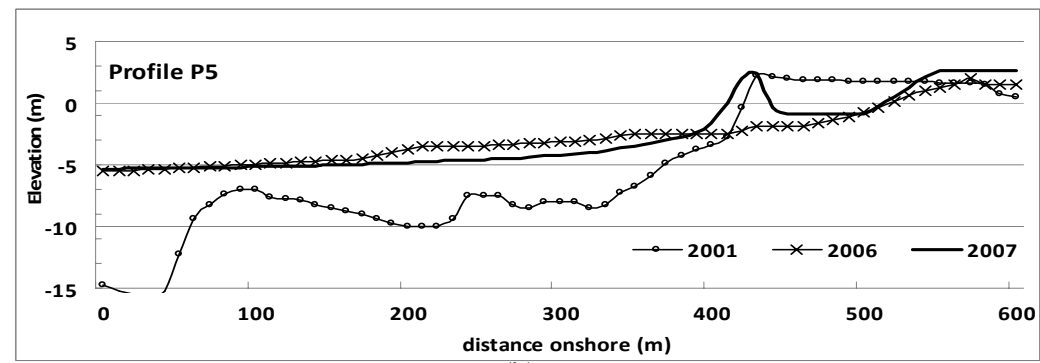

(b)

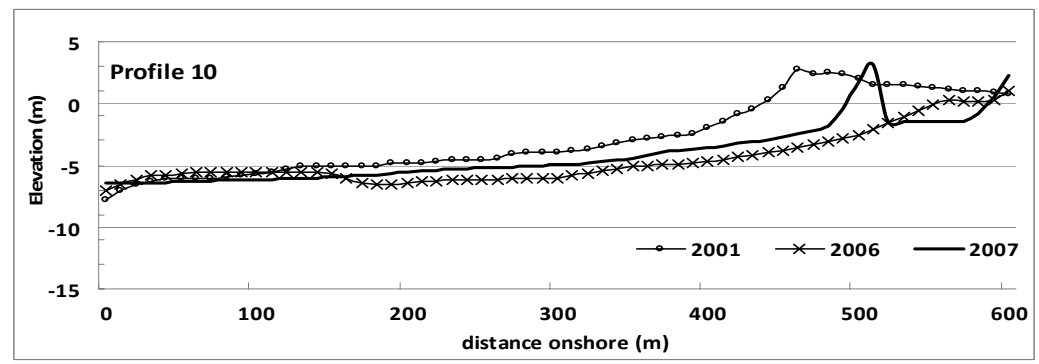

(c)

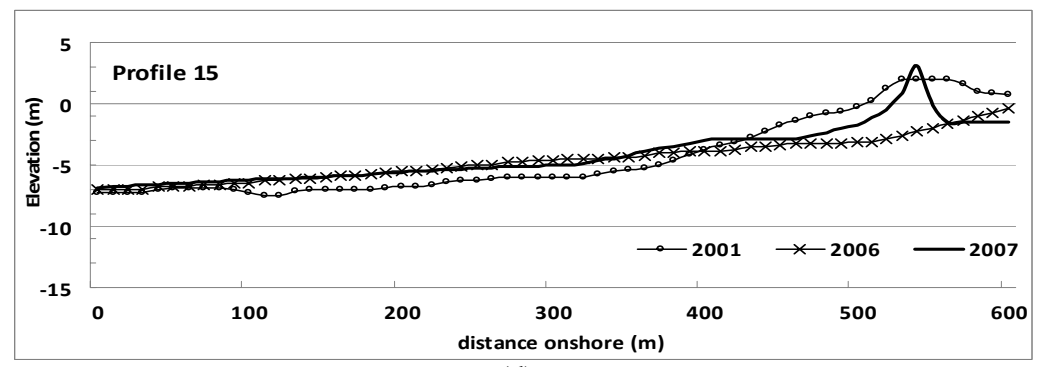

(d)

Figure 3.12: Four representative coastal profiles describing the morphological development in time along the coast which were derived from the DEMs of 2001, 2006 and 2007. 
Morphological development till 1 year after the tsunami (2001-2006)

From the plan view depicted in Figure 3.11a, after one year development in 2006, the morphology shows an irregular surface pattern with prominent shoals and troughs. A significant change from the pre-tsunami morphology is revealed by the partially-removed shoal near profile P1, filling up the trench complex in the middle section near profile P5 and the rebuilt beach at the northeast (near profile P10 and P15).

Four representative profiles of P1, P5, P10 and P15 showed that the area under consideration had been dynamically modified by the tsunami. The filling-up of the trench near profile P5 with an enormous amount of supplied sediments have occurred as the immediate response to the multiple incoming tsunami wave action (i.e. three consecutive waves according to Paris et al., 2007). The deposited amount of sediment in the trench complex was higher than the amount of sediment erosion on the associated foreshore. Apparently the sediment which filled up the trenches did not only originate from erosion of the foreshore and backshore zone of the corresponding profile, but must have partially come from elsewhere.

Profile P15 represents the least artificially modified coastal stretch. Here, it can be observed that the difference between foreshore and backshore erosion and shoreface accretion was small. Profile P10 shows significant erosion both in the shoreface and foreshore zone.

Overall, in this early development period of the coastal morphology, the sediment re-distributed in such a way that foreshore and backshore erosion coincided with shoreface accretion in most profiles, except in the northeast region (P10), where a significant amount of deposition occurred both on the shoreface and foreshore.

\section{Morphological development in 2 years (2006-2007)}

The shoreline change study in section 3 revealed that the pre-tsunami beach disappeared as an early response to the earthquake and tsunami, and a new beach developed further landward. Note that as a means of inland protection from further shoreline retreat, a new seawall was built between August 2006 (near profile P1) and December 2006 (near P10), along the new position of the shoreline.

The DEM 2007 shows that the shoal at the southwest near P1 has completely been removed and the shoreface morphology towards the middle and the northeast subregion (i.e. from P5 to P15) became smoother compared to the 
earlier development (DEM 2006). Figure 3.11b reveals that since 2006, the sediments have been further re-distributed along the entire shoreface by the flattened shoal near P1, slight erosion in the shoreface of P5, deposition in the shoreface of P10, and almost no change in the shoreface of P15. This recent development of the shoreface shows that the shoreface profile was developing towards the pre-tsunami slope gradient, two years after the tsunami.

Table 3.2: Sediment volume change at Ulee Lheue (in $10^{3} \mathrm{~m}^{3}$ )

\begin{tabular}{ccccc}
\hline Period & Erosion & Deposition & Net change & Note \\
\hline $2001-2006$ & 716 & 924 & 208 & Accreting \\
\hline $2006-2007$ & 614 & 397 & -217 & Eroding \\
\hline
\end{tabular}

A summary of the total volume change in $\mathrm{m}^{3}$ by subtracting two pairs of consecutive DEMs is displayed in Table 3.2. One year after the tsunami (2006), the net sediment volume change reveals significant sediment input to the shoreface, while the foreshore zone experienced severe erosion. In the following year (2007), the sediment went out of the coastal section as the shoreface bed was smoothened.

\subsection{Discussion}

Understanding the development of the foreshore zone morphology is considered crucial in this case since it is the most morphologically active part of a short-term scale development of a coastal zone. In this section, the analysis of short-term morphological development of the coastal zone after being hit by the earthquake and tsunami will be discussed. Aspects such as the coastal boundary of two different coasts and the influence of land subsidence leading to the short-term development are considered.

\subsubsection{Influence of the coastal geomorphic settings}

In general, chaotic shoreline undulations created by the tsunami along the northeast and west coasts of Banda Aceh developed into less undulating shorelines several months after the tsunami. Both coasts showed chaotic shorelines as the response to the tsunami waves. It is expected that after the event, the wave climate returned to normal, similar to the pre-tsunami condition. Before the tsunami, the surf zone of the northwest coast and the west coast were usually extended on 
average about $10 \mathrm{~m}$ and $20 \mathrm{~m}$ seaward of the water line, respectively. Under a similar wave climate condition as before the tsunami, the new foreshore on both coasts should have had similar surfzone widths. Nevertheless, four days after the tsunami, the wave breaking lines of both coasts were situated very close to the water line. Figure $3.7 \mathrm{~b}$ shows that the surfzone widths of both coasts were narrower in the early days after the tsunami, which suggests that the foreshore were out of the equilibrium.

Subsequently, the coasts experienced a morphological adjustment process. Within 6 months, the shoreline undulations of both coasts were gradually decreasing and the foreshore slope became straighter. This 'beach recovery' process is comparable to the post-storm recovery study of a category 3-hurricane Ivan along the Northwestern Florida Barrier-Island coasts over a short time period conducted by Wang et al. (2006). The post-storm foreshore slope approached the pre-storm slope within only 30 days. This suggests that the foreshore restored its pre-storm equilibrium within a relatively short period of time.

Although this morphological adjustment occurred on both coasts, interestingly, they developed in opposite trends from their pre-tsunami positions. Ulee Lheue, on the northwest coast, experienced ongoing erosion of about $15 \%$ of the total sediment loss due to the tsunami; Lampu Uk on the west coast gained back $60 \%$ of the sediment loss due to the tsunami after 6 months. These numbers were derived from the sediment volume changes in the foreshore zone displayed in Figures 3.8 and 3.10 .

The northwest coast of Banda Aceh has a narrow and steep inner shelf (slope break at $50 \mathrm{~m}$ depth was situated ca. $4 \mathrm{~km}$ from the shoreline). As the offshore sea bed of the northwest coast was plunging to a depth of over $200 \mathrm{~m}$ from the slope break, some sediment which was re-distributed during the tsunami may have been deposited in the deep off-shore. Also, according to observations from several earlier studies (Gibbons and Gelfenbaum, 2005; Jaffe et al., 2006; Meilianda et al., 2006, Dohmen-Janssen et al., 2006 and Paris et al. 2007) sediment was deposited inland. Much of the sediment may never return to the shoreface as the influence of the waves was considerably less at the offshore and inland deposits may have been settled or consolidated. Therefore, temporary sediment storage in the shoreface (e.g. the bumpy surface in DEM 2006 in Fig. 3.11 and 3.12) must be considerably less than that of the west coast. This may explain the ongoing erosion revealed from the net sediment transport after two years of development, as evident in Table 3.2. 
On the west coast, a certain amount of sediment was regained from temporary sediment storage somewhere further offshore to the littoral zone which facilitated the gradual advancement of the foreshore zone. This can only be possible if the seaward coastal boundary (i.e. shoreface) were wide enough with a gentle slope that could accommodate such temporary sediment storage after being re-distributed by extreme-event waves (e.g. Wang, et al. 2006; Morton, et al. 1994). Indeed, the inner shelf (i.e. slope break of $50 \mathrm{~m}$ depth) of the west coast was considerably wide, i.e. ca. $15 \mathrm{~km}$ from the shoreline.

Furthermore, from the fieldwork which was conducted in August 2006, it was observed that the tsunami-related scours on the beach (backshore) were filled in with thick sand deposits and the beach was more elevated than previously observed. As the result of the erosion combined with the land subsidence, after the tsunami, a sand-rich coast tend to recover by shifting the foreshore landward and rapidly accumulate the amount of sand on top of the old backshore. This accretion somehow created a problem for the inhabitants because the existing coastal road was gradually overtopped by sand.

Taking into account that the Lampu Uk is typically a sand-rich coast, the foreshore recovery stages during the first nearly-two years (December 2004 to August 2006) was comparable to that of the sand-rich southeastern Texas coast, USA after the Alicia, a category-3 hurricane with a storm surge of over $3.9 \mathrm{~m}$, providing the scale of the event is different from that of the tsunami (tsunami waves were recorded to be $10 \mathrm{~m}$ high in Lampu Uk). Within two years aftermath, Morton, et al. (1994) examined that after the Alicia, the first stage of foreshore response lasted about one year, and involved shoreward sand migration, foreshore deposition, and rapid advancement of the berm crest. This was followed by the second stage where sediments of the aggrading berm crest were eroded by high waves (during hurricane) which transported them landward, thereby aggrading the backshore near the post-storm erosional escarpment. From the two stages, the new beach material will be imprinted as the unconformable geological strata to understand the occurrence of such extreme event at the particular coast in history (e.g. when a core sample would be taken on the site).

Overall, the stages of recovery process of a coast affected by a tsunami are comparable to that affected by a hurricane; it experienced initial rapid adjustment of the foreshore slope and shoreline undulations, and subsequently followed longer period of shoreface re-organization into a smoother surface. We argue that after 6 month, the foreshore has asymptotically reached a short-term equilibrium. Moreover, the type of geomorphic settings (e.g. foreshore slope and the shoreface 
and innershelf width and their geological deposits) and the aftermath sediment characteristics and availability (sand-poor or sand-rich coastal environment) determine the trend of morphological development of the coast after the tsunami. This analysis expands the horizon of understanding the role of geomorphic settings to the sediment deposition and re-distribution by the tsunami waves from several field observations at the same location which were previously conducted by Umitsu et al. (2007), Narayana et al. (2007), and Gelfenbaum and Jaffe (2003).

The observed landward-shift of the new foreshore should be considered here in as caused by the erosion due to the tsunami, the result of rapid adjustment stage and also combined with the effect of land subsidence, which will be discussed in the subsequent subsection. The striking evidence of disappearing ebbtide delta lobe after two years (near profile P1 of Fig. 3.12) development remains not well-understood at present. It requires thorough inspection, for instance, by using in-situ data to be able to describe the most likely process leading to the complete removal of the remaining lobe.

\subsubsection{Influence of land subsidence to the coastal morphological development}

Evidences of land subsidence were obtained in this study by comparing the two photographs of coastal structures at the same location and two beach profile elevations of pre- and post-tsunami situations derived from the DEM 2001 and DEM 2006 at Ulee Lheue. Figure 3.13a shows the remnant of Ulee Lheue beach as seen from the bridge, facing seaward on 21 January 2005 (after the earthquake of December 2004) during the low tide level at $+0.0 \mathrm{~m}$ from MLWL. Figure 3.13b shows the same location on 12 April 2005 after the earthquake of March 2005) during the rising tide at $+0.6 \mathrm{~m}$ from MLWL. Knowing that the elevation of the coastal structure remnants in Figure 3.13a was about $+1.8 \mathrm{~m}$ from MLWL, and of the remnants in Figure 3.13b about $+0.6 \mathrm{~m}$ from MLWL, the subsidence of the location was estimated at about $0.6 \mathrm{~m}$.

Some evidence of land subsidence can also be concluded from the crossshore profile derived from the DEMs in Figure 3.12. From the images of the Ulee Lheue coast before and after the tsunami (i.e. 23 June 2004 and 30 December 2004), some building floors in the vicinity of profile P1 and P10 were still intact, leading to the conclusion that the surface of the area was not stripped off by the tsunami waves. 


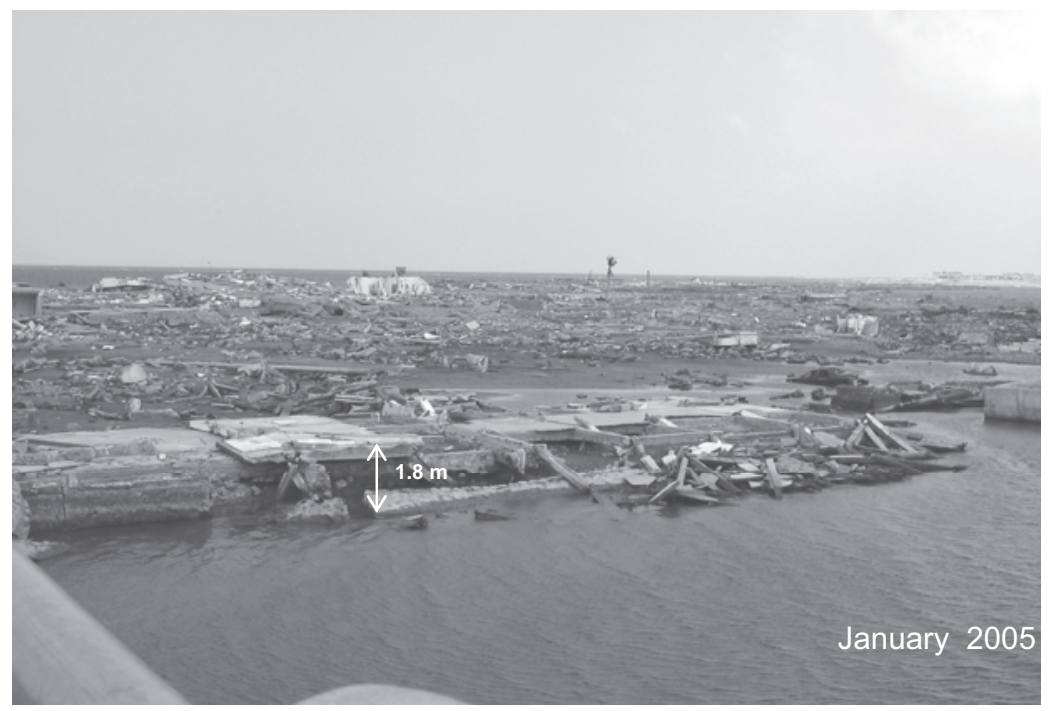

(a)

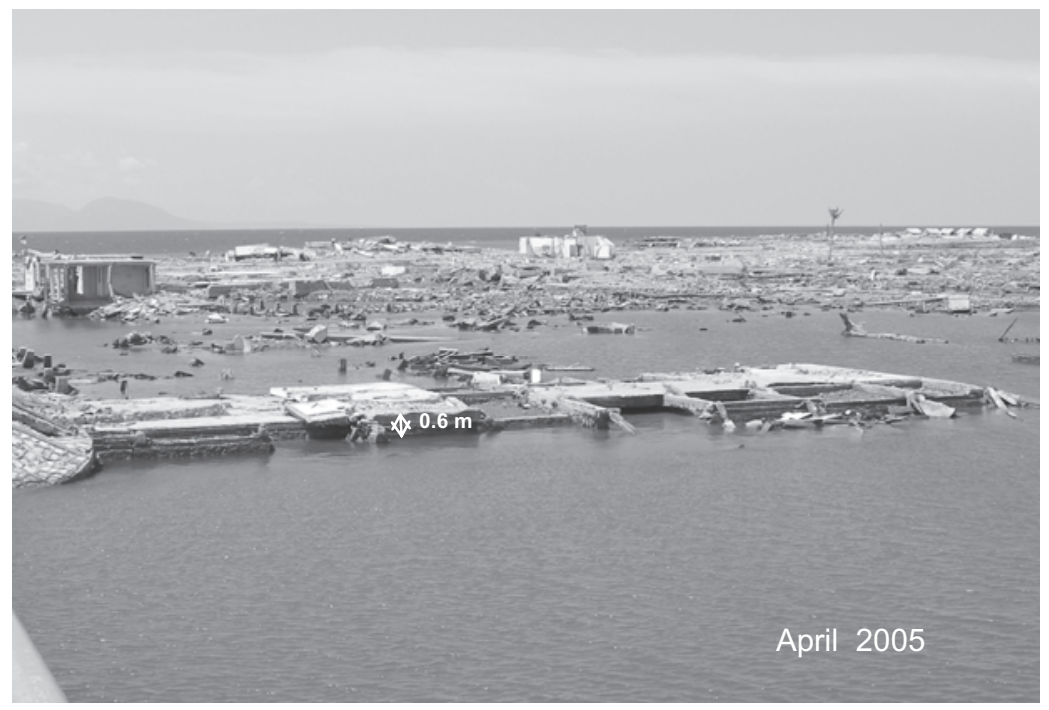

(b)

Figure 3.13: Evidence of land subsidence from the coastal building remnants on the backbarrier of Ulee Lheue coast, which reveal vertical changes relative to sea level. (a) On 21 January 2005 during the low tide (+0.0 m); (b) On 12 April 2005 (after the great earthquake on 28 March 2005) during the rising tide $(+0.6 \mathrm{~m})$. Further description is in subsection 3.2.1. 
Despite this, Figure 3.12a shows that at a distance of $560 \mathrm{~m}$ onshore, the elevation of profile P1 in 2001 is approximately $1.0 \mathrm{~m}$ higher than that of 2006. Similarly, at a distance of ca. $580 \mathrm{~m}$ onshore, the elevation of profile P10 is approximately $1.0 \mathrm{~m}$ higher than that of 2006. Taking into account the uncertainty from the TIN interpolation of $\pm 0.5 \mathrm{~m}$, the land subsidence indicated by these elevation differences was in a comparable magnitude with the evidence shown in Figure 3.13. Furthermore, Meltzner, et al. (2006) under-estimated the constraint of land subsidence in this particular coast from satellite images within the range of 0.1 to $0.2 \mathrm{~m}$. Providing these rough and speculative estimates, one should treat them in a precaution manner. The ongoing shoreline retreat at Ulee Lheue in 6 month after the tsunami suggests that the extent of coastal erosion by the tsunami and the lack of sediment supply in the littoral zone after the tsunami could not keep the pace with the sudden change of coastal elevation due to the land subsidence. As a result, the shoreline was retreating even further.

Evidence of subsidence on the west coast can visually be observed at several places along the coast. The submerged tree trunks and mangrove trees in the surf zone of a highly energetic coast constitute reasonable subsidence evidence. Land subsidence magnitude at the west coast of Banda Aceh reported by Gibbons and Gelfenbaum (2005) reported in a range of 1 to $2 \mathrm{~m}$. Nevertheless, this magnitude may also include the effect of erosion caused by the tsunami. On such a sand-rich environment, the amount of re-distributed sediment back to the shore may have exceeded the magnitude of the elevation difference caused by the land subsidence.

\subsection{Conclusions}

A combination of satellite images, topographic and bathymetric data from different sources and from multiple years were used in this study to observe the changes and development of two tsunami-affected coastal sections near Banda Aceh. The data covered a small spatial scale (approximately 1 to $3 \mathrm{~km}$ ) of two different coastal geomorphic settings on the northwest and west coasts of Banda Aceh city. An attempt to integrate several available data sources led to the selection of the following methods: i) Multi-shoreline identification in the foreshore zone; and ii) Multi-temporal DEMs in the shoreface, foreshore and backshore.

This data-driven analysis explores the utmost usefulness of the multi-source data and field observations to answer the main research question in this study, which is on how the coast developed after the tsunami on a relatively short time scale (RQ2). More detailed formulated questions are answered in the followings. 
a) What are the magnitude and spatial distribution of the morphological changes due to the tsunami and subsidence?

Answer: At a sand-poor northwest coast, Ulee Lheue, the shoreline retreated on average about $73 \mathrm{~m}$, which displayed a chaotic shoreline, destroyed coastal structures and severely eroded and breached beach ridges. At a sand-rich west coast, Lampu Uk, the shoreline retreated as far as $77 \mathrm{~m}$ landward and chaotic as well on the northern part, while the coastal protection structures such as the beach revetment may have prevented the southern part from being severely eroded. The beach was scoured by strong waves which created depressions at some locations.

b) How did the coast with different morphological settings develop in the short time after the tsunami?

Answer: In the early days after the tsunami, both coasts experienced foreshore morphological adjustment, revealed by smoothening shoreline undulations and foreshore slope. After 6 months development, the two coasts developed towards a contrasting behaviour. Ulee Lheue on the northwest coast experienced ongoing erosion of about $15 \%$ of the total sediment loss due to the tsunami, while $60 \%$ of Lampu Uk on the west coast was compensated for accretion. Sediment redistribution processes in the shoreface occurred more slowly than in the foreshore zone. In the sand-poor northwest coast of Ulee Lheue, two years after the tsunami, the sediment supply could not keep the pace with the sudden change of coastal elevation due to the land subsidence. As a result, the shoreline was retreating further. On the other hand, in the sand-rich west coast, Lampu Uk, a remarkable pile of sand was accumulated on the backshore. The width and the slope gradient of the shoreface and of the inner shelf as well as the sediment availability and characteristics in front of each coast control this contrasting behaviour. The amount of re-distributed sediment back to the shore may have exceeded the magnitude of the elevation difference caused by the land subsidence.

c) What are the opportunities and the pitfalls of using the multi-source data sets to study the morphological development in a less-investigated study location? Answer: The strong point of the data-driven method using multi-source data sets is that there is an opportunity to enhance the data quality which was scarce initially by filling in the data gaps with data from other sources. Moreover, interpretation of the data is validated using observations from the fieldwork, or using information from literature. The uncertainty remains to be further considered in 
the future work, particularly in dealing with the dynamics of multi-source data, which was difficult to determine. Finally, this study contributes to the knowledge on how different coastal characteristics respond to and develop in the short-term after being affected by a huge natural event like the tsunami of 26 December 2004. 


\title{
Chapter 4
}

\section{Scenarios for future development of a sand- poor coastal environment subject to tectonic and tsunami events}

\begin{abstract}
It was recorded in history and imprinted in its coastal morphology of the Banda Aceh region, that tectonic land subsidence and tsunami events occurred frequently; i.e. once every 20 to 30 years. In this study, tectonic land subsidence and tsunami events are introduced in sediment budget calculations as intermittent sediment budget components which are essential to estimate the overall sediment budgets, i.e. in addition to the sediment budgets due to regular wave condition. We discuss two points of interests: the coastal processes related to the geomorphic characteristics of the northwest coast of Banda Aceh and the morphological development of this coast after a tsunami and land subsidence on the time scale of one hundred years.

Frequent earthquakes causing high probability of land subsidence and tsunami recurrence (i.e. 20 to 30 years) can be the worst scenario for the development of such a tsunami-affected coast in the next hundred years. The rate of shoreline retreat caused by tectonic land subsidence was remarkable at the tectonically unstable part of the Banda Aceh coast, and was equal to $-46 \mathrm{~m} /$ event. Small magnitude tsunami events that occurred in the past century inferred a significant amount of shoreline retreat at the tectonically stable coastal section which can be up to $-27 \mathrm{~m} /$ event. These rates of (sudden) shoreline position change are higher than that due to gradual sea-level rise in this region.

Both earthquakes and tsunamis have remarkable impacts on the coastal morphology and its future development. The long-term trend of coastal development may be interrupted, which also means that a long-term equilibrium condition may not exist. At an accreting and tectonically stable coast (e.g. Kuala Gigieng) the rate of advancing shoreline is halted due to the expected effect of sea-level rise, and can be further halted by the effect of erosion by the intermittent tsunami events. On the other hand, at an eroding and tectonically unstable coast (e.g. Lambadeuk), the sea-level rise increases the rate of shoreline retreat, and can further be exacerbated by the effect of land subsidence which may cause an irreversible shoreline retreat, especially in the sand-poor coastal environment. This suggests that the damage caused by the probable recurrence of tsunami and land subsidence events to the coastal morphology within a century can be an order of magnitude greater than the effect of the well-known sea-level rise due to global climate change, which is often considered important in modern coastal management practices. This study reveals that their magnitudes and frequencies of earthquakes and tsunamis are important to be taken into account in studying the dynamics of the coastal morphological development in the tectonically active region.
\end{abstract}




\subsection{Introduction}

Coastal morphology is continuously modified by the sediment transport due to waves, currents and tides. This process may have been accompanied with the significant effect of the sea-level rise at some locations in the world in the past century. The coast can be modified by these actions on the scale of seconds (e.g. individual sediment particle movements) or over years (e.g. net longshore sediment transport), which in this study are called the continuous forcing factors. In an ideal case, these forcing factors provide a long-term trend of coastal morphological development (e.g. a trend in coastline position change). In a real world, however, storms, hurricanes, tsunamis and tectonic activities occur and affect the coastal morphology in a shorter period (intermittent). These intermittent forcing factors can significantly deviate or impede the trend of the morphological development.

Coastal processes in a sand-rich beach environment in a tectonically stable coastal system have been of great interest to coastal researchers in the past hundred years who provided advanced knowledge and engineering solutions to coastal problems (Fenneman, 1902; Johnson, 1919; Bruun, 1962; Dean and Maurmeyer, 1983; Larson, 1991). Most of the coastal process analysis has been done for a typical sand-rich environment where the supply of sediment to the littoral system is continuous and any changes in wave action resulting in a morphological feedback of the entire shoreface. The morphological feedback concept was initially proposed by Bruun (1962).

Nevertheless, many coastal systems in the world do not possess these typical characteristics. In fact, approximately $80 \%$ of the world's coastlines are rocky coasts or sand-poor environment, which tended to receive relatively little attention in the scientific literature (Sunamura, 1992). On such a rocky coast, sand supply to the littoral zone is limited, and thus the beach morphology is configured as a thin layer of sandy beach, perched on top of the older bedrock deposits. In addition, the point of sand starvation may have been reached at some locations as significant onshore transport has been cut off due to the depletion of relict shelf sources.

The geology underlying the shoreface frequently plays a role in shoreline behaviour (Riggs et al., 1995; Cowell et al., 1995). Consequently, the concept of morphological development of a coast proposed by Bruun (1962) to a great extent is unsuitable, particularly for a highly complex sedimentary environment such as the nearshore zone with large spatial and temporal variations in sediment supply, wave conditions and coastal retreat rates (Cooper and Pilkey, 2004). Moreover, the shoreface responded to sea-level rise in a variety of ways depending upon grain 
size, wave conditions, sediment supply and several other factors. The shoreface, thus, would not be expected to retain its shape as it evolved (Swift, 1976).

At present, understanding of the full range of processes that govern coastal sediment transport is incomplete (Niedoroda, et al., 1995). Therefore, modelling coastal evolution at the moment takes a use-specific approach as there is no universal model (Hulscher, 2003). Herein, scales play a central role, especially the time scale. The coastal morphology in the tectonically active region is influenced by tectonic activities and the potentially resulting tsunamis. Forcing factors, either continuous or intermittent, change the coastal morphology in time and space. Despite this, they were hardly taken into consideration in the context of coastal morphological development. The lack of general knowledge, supporting data, evidence and awareness of the impact of such events prevent this from being done. Moreover, such events often occurred in the scientifically less investigated coastal regions. The giant earthquake and tsunami that occurred on 26 December 2004 in the Indian Ocean provides the momentum for further research and investigations to fill in this knowledge gap.

The present study emphasizes analysis of coastal morphological development by considering two points of interests: i) morphological development of a sand-poor coastal environment; and ii) influence of tectonic activities (e.g. tsunami and land subsidence) to this type of coast. The main objective of the present study is to propose scenarios for future development of a tsunami-affected coast which has a sand-poor coastal environment. The scenarios accommodate the interaction between continuous and intermittent forcing factors and their feedback to the pre-defined sand-poor coastal morphology within an engineering time scale (100 years). The prediction of the morphological shape in the end of the next century is not our intention in this case. Rather, we are interested in providing information on the changes of the shoreline orientation and position as well as the shoreface profiles relative to the pre-tsunami condition.

The longer the time scale being considered, the more forcing factors with different frequencies are involved in the coastal morphological development. In a tectonically active region, sudden or rapid tectonic uplift or subsidence and the tsunamis are considered as the intermittent forcing factors within a medium- to long-term coastal development. Specifically in a hundred-year time scale, littoral sediment transport induced by wave actions (continuous forcing factors) plays an important role for the development of the coastal morphology. Shoreline position and orientation are two important parameters to take into account in determining the state of the coast; whether it is an eroding or an accreting coast. As a result of 
the sudden impact of a tsunami or a land subsidence (intermittent forcing factors), the shoreline position and orientation as well as the shoreface morphology may change considerably. These changes lead to a new coastal state and determine the subsequent morphological development.

In addition, Riggs et al. (1995) suggested that it is essential to understand the geomorphic settings of a coast before attempting to model the large-scale behaviour of these types of coastal systems. Therefore, the frequency and magnitude of the intermittent forcing factors as well as the coastal morphology feedback under the continuous forcing factors should be incorporated in the scenarios of the morphological development of the coast in future. To attest the abovementioned hypothesis, the following research questions will be answered in this study:

RQ3: What kind of variability is expected in the morphological development of the Banda Aceh coast in the next century?

d) What are the frequency and magnitude of forcing factors involved in the coastal morphological development related to the earthquake and tsunami?

e) How did the geomorphic settings and the continuous and intermittent forcing factors influence the morphological development of the Banda Aceh coast in the past century?

f) How will the geomorphic settings of the coast since the December 2004 tsunami and the forcing factors in different scenarios influence the morphological development in the next century?

Aceh Province, on the northern tip of Sumatra Island, Indonesia is surrounded by the sea in the west, northwest and east. The capital city, Banda Aceh $\left(95^{0} \mathrm{~N}, 5^{0} \mathrm{E}\right.$; Fig. 1.1), faces the Andaman Sea to the northwest. In this study, we investigate the coastal morphological development of the northwest coast of Banda Aceh (to be called as Banda Aceh coast from here on) following the earthquake and tsunami of 26 December 2004. The coastal area is located in the most tectonically active region in the world associated with the subduction zone of Indo-Australian plate underneath the Southeast-Asian plate.

To provide evidence of intermittent forcing factor occurrence, we analyzed the historic development of the coastal morphology and compared those data with occurrences of the recorded earthquake leading to tsunami and land subsidence. The rate of shoreline position change in time and the changes in shoreline orientation is the important parameter in this study. To quantify this, we 
analysed the theoretical spatial boundaries of the coastal system during a development over a century. An analysis of the sediment budgets influenced by the continuous forcing factors provides a basis for forecasting the future morphological development in terms of sediment transport rate. This is subsequently coupled with different scenarios incorporating the influence of the different intermittent forcing factors that may modify or alter the morphological development trend by the continuous forcing factors.

Identification of the important continuous and intermittent forcing factors in the morphological development of the Banda Aceh coast is described in Section 4.2 of this paper. Section 4.3 describes the selection of specific coastal sections and their morphological boundaries and analysis of historical shoreline evolution in relation to different inter-related forcing factors. The scenarios for forecasting future coastal development is discussed in Section 4.4. Important remarks are discussed in Section 4.5 and followed by conclusions in Section 4.6.

\subsection{Forcing Factors}

\subsubsection{Continuous forcing factors}

\section{Waves, currents and tides}

We derived the wave climate of the Banda Aceh coast from eleven-year daily wind data records from 1995 to 2005. The wind data were recorded by the Department of Meteorology and Geophysics in Banda Aceh, and subsequently translated into statistical wave heights and periods as functions of wind velocity, duration and fetch (CERC, 1992). Surface and tidal currents are not well-recorded in this coastal region. The tides moderately range of $1.70 \mathrm{~m}$ from MHWL to MLWL (UP-PSDA, 2003). From the data, we found that the prevailing wave directions were from the northwest and the northeast.

The southwest monsoon occurs between April and September and is characterized by relatively rough waves coming from the northwest at the Banda Aceh coast. About 53\% of the waves approach the coast with a significant wave height of $1.0 \mathrm{~m}$ with a period of 3 seconds. During the northeast monsoon between October and March, the climate tends to be milder with $30 \%$ of the waves approaching from the northeast with a significant wave height of also $1 \mathrm{~m}$ and a period of 4.5 seconds. 
Eustatic sea-level rise is a major concern in coastal management in many parts of the world today. In February 2007, the Inter-governmental Panel on Climate Change (IPCC) warned of sea-level rises in Indonesia of 0.2 to $0.6 \mathrm{~m}$ by the end of the century (IPCC, 2007), making coastal populations more vulnerable to flooding and more intense storms such as tropical cyclones.

\subsubsection{Intermittent forcing factors}

\section{Neo-tectonics}

The local neotectonics are driven by the process of energy accumulation in the subduction zone due to the movements of the subducting megathrust (IndoAustralian plate) beneath the passive continental margin (Southeast Asian plate) comprising the Sumatran Fault system (SFS; see location in Fig. 1.1). The accumulating energy induces strain which increases with time and eventually releases the accumulated energy in the form of powerful earthquakes. Upon the energy release, the subduction process restarts to accumulate new energy leading to new strain until the energy will be released again in one or more subsequent earthquakes. Such a release of maximum accumulation of energy for example triggered the major earthquake of 26 December 2004. Natawidjaja, et al. (2007) studied on the growth of microatolls relative to lowest low tide which characterized the return period of accumulating strain release associated with tectonic plate's movement in Sumatra. The evolving strain accumulation towards several major earthquakes resulted in several uplifts in the region of Mentawai Island, off the southwest coast of Sumatra, and subsidence on the main island of Sumatra. They suggested that the period of such an energy release process in the subduction zone occurs approximately every 200 years. Such an evolution of strain release of the neotectonics has a regional impact because both locations are within the same subduction zone and therefore affect also northern Sumatra (near Banda Aceh).

Simply explained, neotectonics may cause slow and rapid land subsidence or uplift. The slow subsidence or uplift can be linked to the rate of subducting movement, or the vertical component of faulting movement (normal faulting), but can also be associated with the liquefaction of mud or a peat layer beneath the associated tectonic plates as a result of intensive seismicity. On the other hand, a sudden vertical movement (subsidence or uplift) may be associated with the energy release of the maximum strain accumulation of the subduction process. The 
impact it has on the coastal morphology depends very much on the amount of energy being released which translates into the magnitude of the earthquake producing the vertical movement of the earth's crust. The magnitudes and incidences of these processes are difficult to predict. Nevertheless, their impact is imprinted on the earth's landscape (geomorphology) in history.

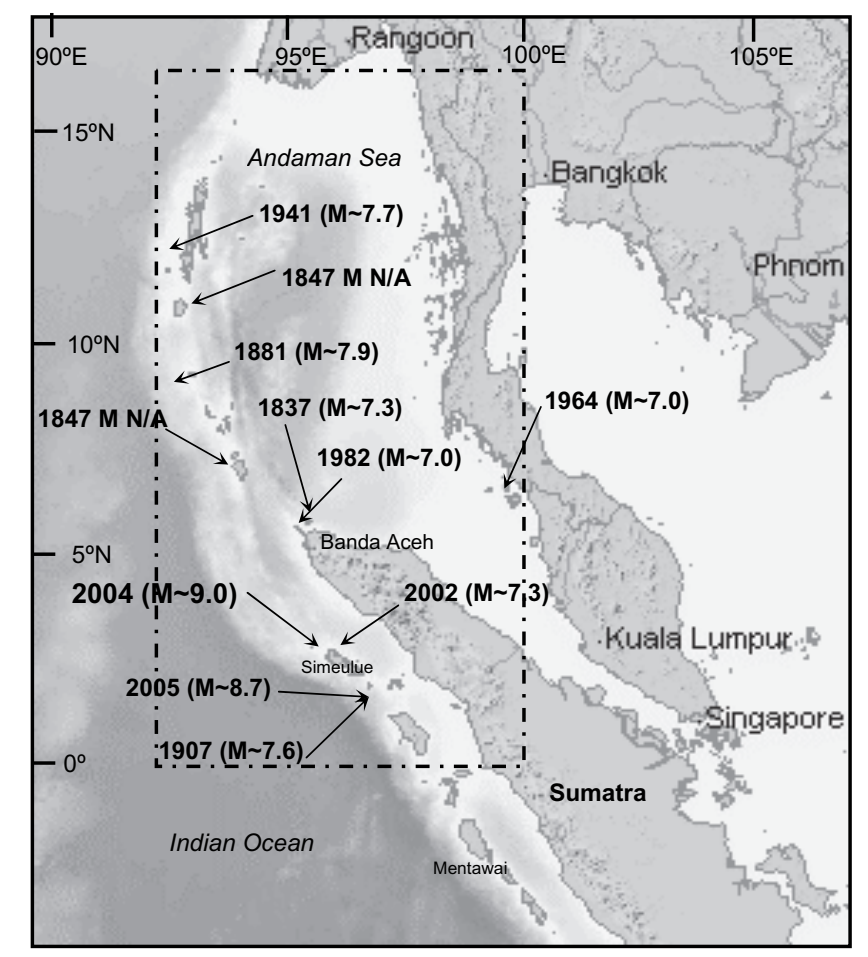

Figure 4.1: Banda Aceh, at the northwest tip of Sumatra Island and epicentre locations of several earthquakes during the period of 1900 to 2008. The rectangle dashed line shows the boundary of earthquake and tsunami database retrieved for the present study from NGDCNOAA (2008).

\section{Tsunami events}

If a vertical displacement of the earth's crust occurred under the sea, the column of water directly above it is also vertically displaced, and generated 'elastic waves' which are generally called tsunamis. The size of a tsunami is directly related to the shape of the rupture zone, the rate of displacement and sense of motion of the 
ocean-floor in the source areas (epicentre), the amount of displacement of the rupture zone, and the water depth. The earthquake that occurred 26 December 2004 is related to the energy release of maximum accumulated strain.

Tsunami event data in this study were obtained from the NGDC-NOAA tsunami database (NGDC-NOAA, 2008). It provides a listing of historical tsunami source events and run up locations throughout the world ranging from 2000 B.C. to the present. The events were gathered from scientific and scholarly sources, regional and worldwide catalogues, tide gauge reports, individual event reports, and unpublished works. The NGDC-NOAA recorded at least 41 events of earthquakes which magnitudes were of $M>7.0$ occurred in the region near Banda Aceh in the last 200 years. When we took the geographical rectangle coordinate pair of $0^{0}$ to $17^{\circ} \mathrm{N}$, and $92^{\circ}$ to $100^{\circ} \mathrm{E}$, as the data search boundaries (see Fig. 4.1), we found 26 significant earthquakes generated tsunamis out of these 41 significant earthquake events. We checked that there was no difference of tsunami occurrence probability by enlarging this geographic boundary to another couple of degrees. This is because the earthquakes with epicentres, for instance, further south or north is considered far enough to have tsunami waves transmitted to Banda Aceh during the recorded period. Furthermore, extending west and east boundaries was irrelevant since the epicentres of the earthquakes were concentrated in the subduction zone which is already covered within this boundary.

Information about the uncertainty of the recorded earthquake and tsunami events in history is given in the tsunami data base of the NGDC-NOAA (2008). The uncertainty partly stems from possible errors in the data base, for example, before the invention of seismographs in the late 1800s magnitudes, when the times and locations of earthquakes and tsunami sources were determined from descriptions of earthquake damage and tsunami effects. Earthquake epicenters and tsunami source locations may have been assigned to the wrong places when the names of localities were incorrectly transcribed or when some localities had identical or very similar names. Errors may have also been introduced when the local times of earthquakes and tsunami reports were incorrectly converted to Universal Coordinated Time by catalogers. Earthquake and tsunami events can also be listed twice when the dates are recorded in different sources according to the Julian or the Gregorian calendars. As a result, the earthquake and tsunami databases may include listings of events on different dates that are actually descriptions of the same event. A more complete discussion of these errors can be found in Lee, et al. (1988). 
Table 4.1: Earthquakes leading tsunami events affecting Banda Aceh in the period of 1808 to 2008. Geographical boundaries displayed in Figure 4.1.

\begin{tabular}{|c|c|c|c|c|c|}
\hline Date & $\begin{array}{l}\text { Latitude } \\
\text { ( }{ }^{0} \text { North) }\end{array}$ & $\begin{array}{c}\text { Longitude }{ }^{0} \\
\text { East) }\end{array}$ & Location & $\begin{array}{c}\text { EQ } \\
\text { Magnitude }\end{array}$ & $\begin{array}{l}\text { Tsunami } \\
\text { Validity* }\end{array}$ \\
\hline $01 / 09 / 1837$ & 5.5 & 96 & Banda Aceh & 7.3 & 2 \\
\hline $31 / 10 / 1847$ & 7.3 & 94 & $\begin{array}{l}\text { Little Nicobar } \\
\text { Island }\end{array}$ & $\mathrm{N} / \mathrm{A}$ & 3 \\
\hline $19 / 08 / 1868$ & 11.6 & 92.7 & Andaman Island & $\mathrm{N} / \mathrm{A}$ & 4 \\
\hline $31 / 12 / 1881$ & 9 & 92 & $\begin{array}{c}\text { West of Car } \\
\text { Nicobar Island }\end{array}$ & 7.9 & 3 \\
\hline 04/01/1907 & 2 & 94.5 & $\begin{array}{c}\text { NW Sumatra } \\
\text { (Simeulue Island) }\end{array}$ & 7.6 & 4 \\
\hline $26 / 06 / 1941$ & 12.5 & 92.5 & Andaman Sea & 7.6 & 4 \\
\hline $02 / 04 / 1964$ & 5.8 & 95.4 & NW Sumatra & 7.0 & 3 \\
\hline $13 / 09 / 2002$ & 3 & 95 & Andaman Islands & 7.3 & 4 \\
\hline $26 / 12 / 2004$ & 3.3 & 96 & Off West Sumatra & 9.0 & 4 \\
\hline \multicolumn{6}{|l|}{ Note: } \\
\hline \multicolumn{6}{|c|}{ Source: NGDC-NOAA (2008) } \\
\hline \multicolumn{6}{|c|}{ * Tsunami validity: } \\
\hline \multicolumn{6}{|c|}{$4=$ definite tsunami } \\
\hline \multicolumn{6}{|c|}{$3=$ probable tsunami } \\
\hline \multicolumn{6}{|c|}{$2=$ questionable tsunami } \\
\hline \multicolumn{6}{|c|}{$1=$ very doubtful tsunami } \\
\hline $0=$ event like & eiche & & & & \\
\hline
\end{tabular}

Another source of errors may be generated from the measurements associated with a tsunami event, for instance, the maximum runup height or water height reached above the sea-level in meters. Unfortunately, it is not always clear which reference level was used. The tsunami database also includes locations where the tsunami was observed, called runup locations. The same problem that occurs when identifying earthquake epicenters can occur when assigning runup locations, where the names of localities were incorrectly transcribed or where some localities had identical or very similar names. In addition, names of locations can change over time adding to the possibility of errors. If tsunami arrival and travel times are available for specific runup locations, they are included in the database. These data are valuable in verifying tsunami travel time models. The definition used in this database is the arrival or travel time of the first wave that arrives at a runup location. The first wave may not have been the largest wave, therefore, the travel time reported in the original source may have been the second or third wave. Based on these various sources of uncertainty, the validity of the tsunami 
occurrences in the Banda Aceh coast in the past two centuries which are listed in Table 4.1.

\subsection{Shoreline evolution in the past century}

Knowledge about the current state of the coastal system (e.g. its morphology and coastal processes) is required as the initial condition in order to develop scenarios for future morphological development. The coastal morphology directly after the earthquake and tsunami of 26 December 2004 is considered as the current state of morphology of Banda Aceh coast in this study. Furthermore, knowledge on development of the coastal morphology in the past over different time scales is a pre-requisite to determine what kinds of forcing factors were actually involved during the development towards the present observable coastal morphology. Moreover, this is also to identify the extent of the coastal system that has to be considered over the time scale of interest (100 years).

\subsubsection{Defining spatial boundaries of the active part of a coastal system over a-hundred-years time scale}

The natural morphodynamic continuum of a coastal system is represented in this study by the alongshore coastal section (littoral cell extent) and the shore-normal coastal profile. The sediment budget in the coastal system is analyzed with respect to these dimensions. A littoral cell extent is defined by investigating the sediment transport dynamics which are applied within certain boundaries or "control volumes" and also by geologic controls, i.e., geomorphic settings of the shoreface and shoreline dissections (e.g. by river mouths or inlets) within which a complete self-contained or contiguous sediment budget exist. To demonstrate the concept of coupling the intermittent and continuous forcing factors, we select coastal sections which are outside the influence of the river mouths and being the least modified by human interference (e.g. coastal structures).

In this study, we adopt the shoreface boundaries as defined in Figure 3.3 in Chapter 3. Coastal cells 1, 2 and 3 in Figure 4.2 are represented by representative profiles P1, P2 and P3, respectively, which are displayed in Figure 4.3.

The upper shoreface includes the surf zone, beach berm and theoretical depth of closure $\left(h_{c}\right)$ of the upper shoreface. The depth of closure of the upper shoreface in this study rests upon the work of Hallermeier (1981), which is calculated with the following simple approximation: 


$$
h_{c} \approx 2 \bar{H}_{s i g}+11 \sigma
$$

where $\bar{H}_{\text {sig }}$ is the mean annual significant wave height (defined as the annual mean of the highest one-third of waves measured each day), and $\sigma$ is the standard deviation of $\bar{H}_{s i g}$.

The lower shoreface includes the upper (first) break in the slope of the shore-normal coastal profile until the depth where the wave action has little influence on the sediment particles $\left(b_{i}\right)$. The lower and upper shoreface are contiguous, so the offshore boundary of the upper shoreface corresponds to the inshore boundary of the lower shoreface.

For the depth of closure belongs to the lower shoreface, Hallermeier (1981) estimated that the limiting depth of significant on-offshore transport of sand by waves throughout a typical year is:

$$
h_{i}=\left(\bar{H}_{s i g}-0.3 \sigma\right) \bar{T}_{s i g}(g / 5000 D)^{\frac{1}{2}}
$$

where, $\bar{T}_{\text {sig }}$ is the mean annual significant wave period (in seconds) and $D$ is the characteristic grain size of the lower shoreface (in meters). The grain size should be set as the median diameter $\left(D_{50}\right)$. The offshore limit of the upper shoreface is, however, not always distinguished by a sharp break in the slope. Nevertheless, the theoretical closure depth often corresponds approximately to a distinctive break in sediment characteristics. Upper shoreface sands generally are well sorted and often similar to the beach sediments, although there is usually a distinct decrease in mean grain size in the seaward direction (Short, 1999).

\subsubsection{Selection of coastal cells at Banda Aceh coast}

Calculating sediment budget estimates of a coastal environment for a century time scale requires the determination of important components of sediment transport attributed in each selected littoral cell. Those components are schematized in Figure 4.2. We select three particular coastal cells along the Banda Aceh coast; i) Lambadeuk (cell 1), at the southwestern portion of the coast; ii) 
Kuala Gigieng (cell 2), at the northeast portion of the coast; iii) Neuheun (cell 3), at the northeast portion of the coast.

Figure 4.3 displays the calculated depths of closure at Banda Aceh coast $\left(b_{c}\right.$ and $b_{i}$ ) calculated using Equation (4.1) and (4.2) related to each representative profiles P1, P2 and P3 in Figure 4.2 and 4.3. The followings are descriptions of sediment characteristics of each selected coastal section in this study.

\section{Cell 1}

Cell 1 represents the tectonically unstable Lambadeuk coast (see also location in Fig. 1.1). This southwest portion of Banda Aceh coast is associated with the depression zone of the SFS fault, where consecutive events of land subsidence seems to have occurred preceding the most recent earthquake and tsunami of December 2004 (see subsection 4.3.3.).

Littoral cell 1 also exemplifies a coast which has a convex shape of its shoreface's cross-shore profile. This convex shape indicates the prograding delta during the Holocene (see section 2.5 in Chapter 2). The upper shoreface (i.e. from the defined shoreline to the closure depth $\left.h_{c}\right)$ consists of loose fine sand $\left(D_{50}=120\right.$ to $140 \mu \mathrm{m}$ ) which was perched on top of the older deposit layer. Since the tsunami in December 2004, the position of the upper shoreface has shifted $200 \mathrm{~m}$ landward on average and the consolidated material of the old beach ridge was completely removed by the tsunami (profile P1 in Fig. 4.3) and probably also caused by tectonic subsidence (see subsection 3.3.2 in Chapter 3). The shoreface was only slightly eroded by the tsunami due to the effect of moderately resistant bedrock (probably of mudstone; see also Chapter 2). At the depth of $-6.5 \mathrm{~m}$, the shoreface consists of silty clay deposits approximately $1 \mathrm{~m}$ thick only (see also Fig. 2.7a in Chapter 2). The medium sediment grain size at this location is smaller than $60 \mu \mathrm{m}$.

\section{Cell 2}

This littoral cell of Kuala Gigieng has a characteristic transition between the convex (southwestern) and concave shape (northeastern) shorefaces along the Banda Aceh coast. The varying cross-shore profiles along the shore are associated with the tilting that occurred during the Pleistocene (section 2.3.4 in Chapter 2). Sediments on the upper shoreface were fine sands $\left(D_{50}=120\right.$ to $\left.140 \mu \mathrm{m}\right)$, while sandy silty clay $\left(D_{50}<60 \mu \mathrm{m}\right)$ covered the bedrock of the lower shoreface. In the 
modern morphology, the lower shoreface seems to be highly resistant, while the upper shoreface showed remarkable erosion and shoreline retreat (i.e. profile 2 in Fig. 4.3). The December 2004 tsunami eroded severely the sand spits in the vicinity of the Kuala Gigieng inlet and impacted their evolution (Figures 4.4b, 4.4d, 4.4f, $4.4 \mathrm{~h}, 4.4 \mathrm{j}$ and $4.4 \mathrm{l})$. The small river channel joining the Kuala Gigieng inlet is not important to the littoral sediment for cell 2.

\section{Cell 3}

The shoreface profile in Neuheun has a concave shape which developed during the marine regression in the Holocene on top of the uplifted Pleistocene bedrock. The tsunami of 2004 eroded the whole shoreface probably most of the unconsolidated material, up to a considerable depth (approximately 1 to $4 \mathrm{~m}$ ). The shoreline, however, did not retreat so much because the beach contained highly resistant Holocene beach ridges. The beach ridges were slightly breached at the less resistant locations (Fig. 4.7). It was discussed in Chapter 2 (section 2.5.2) that the uplifted bedrock under the modern shoreface sediments probably consisted of soft rock that was eroded by the December 2004's tsunami, compared with the bedrock of cells 1 and 2. After the tsunami, the lower shoreface (depth of $-6.5 \mathrm{~m}$ ) consists of a thin layer (approximately $1 \mathrm{~m}$ thick) of poorly graded sand deposits with $D_{50}=200$ to $250 \mu \mathrm{m}$ on top of approximately $3.5 \mathrm{~m}$ of sandy silty clay.

From the above description, the three representative shoreface profiles show different characteristics, i.e., convex and concave shapes extended offshore, which suggest different characteristics of bedrock resistance to erosion (e.g. by tsunami waves). The importance of recognizing the convex or concave shape of the lower shoreface also lies in determining whether onshore transport of each particular littoral cell may or may not occur; that is under the given wave climate and the loose sediment availability and the characteristics of the bedrock. Here, the geomorphological interpretation discussed in Chapter 2 was used as a proxy to determine the bedrock characteristics and the availability of moveable sediment on the surface layer. Estimate of on-offshore transport is calculated and analysed further in section 4.4.1. 


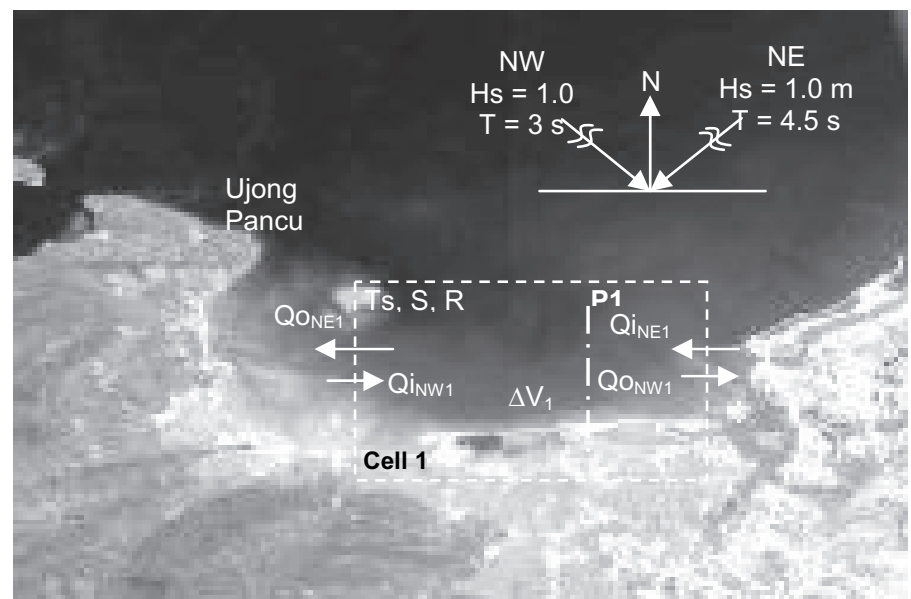

(a)

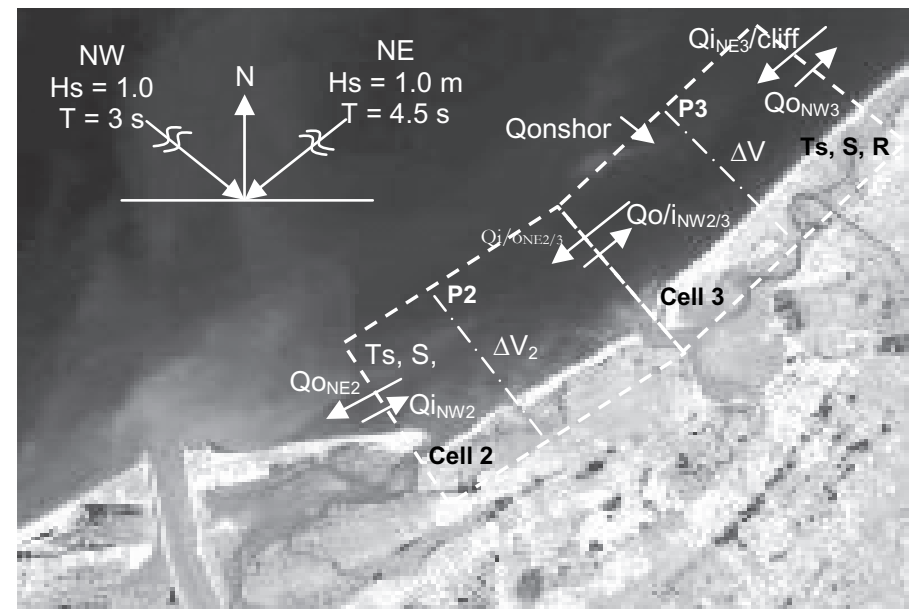

(b)

$\mathrm{Qi}_{\mathrm{NE} 1}$, QONE1 $\mathrm{QONE2}$, Qi/ONE2/3, Qi $\mathrm{NE}_{\mathrm{NE} / \text { cliff }}=$ longshore sediment transport during NE monsoon $\mathrm{Qi}_{\mathrm{NW} 1}$, Q $\mathrm{ONW}_{\mathrm{N} 1}, \mathrm{Qi}_{\mathrm{NW} 2}, \mathrm{Q} / \mathrm{i}_{\mathrm{NW} 2 / 3}$, Qonw3 $=$ longshore sediment transport during SW monsoon

Qonshore (incoming waves from NW) Ts, S, R $=$ onshore sediment transport

= sediment loss due to tsunami, subsidence and Sea-level rise

Figure 4.2: Schematic of sediment budget components encompassing a century time scale of three different littoral cells at the northwest coast of Banda Aceh; (a) Lambadeuk, southwest of Banda Aceh coast, represented as cell 1; (b) Kuala Gigieng and Neuheun, northeast of Banda Aceh coast, represented as cell 2 and cell 3, respectively. (source: the satellite image was acquired on 1 April 2008 of IKONOS image retrieved from CRISPNUS Singapore). 


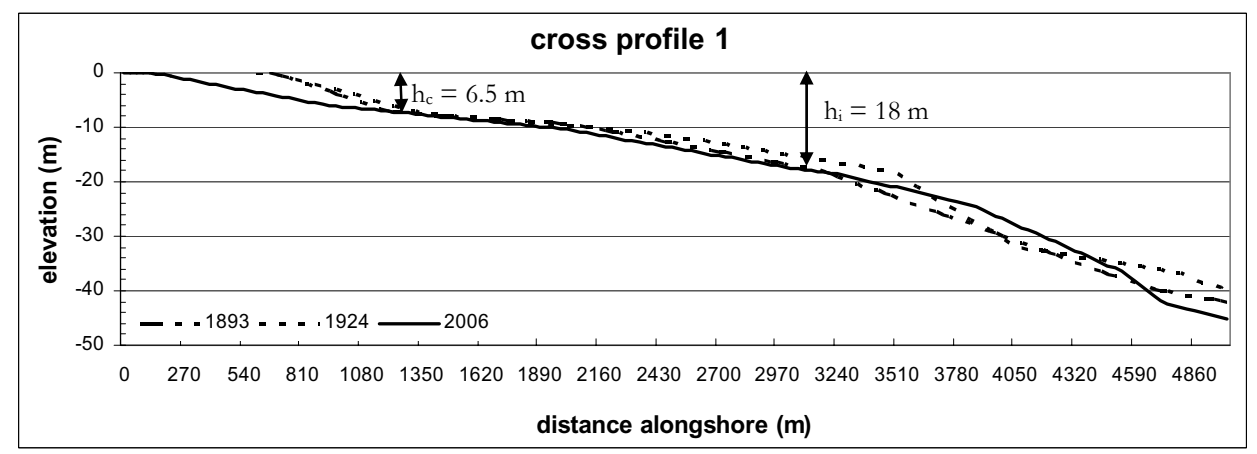

(a)

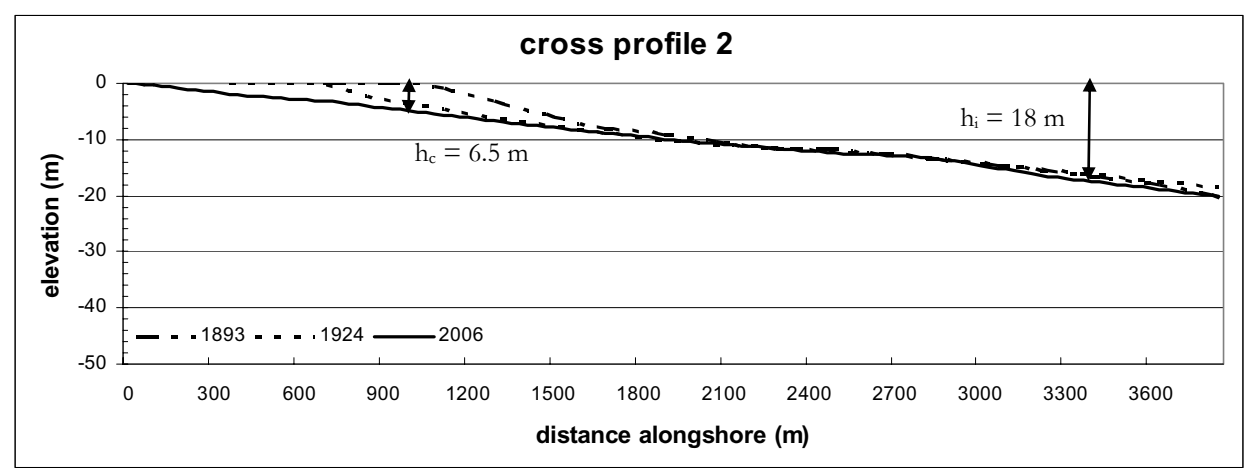

(b)

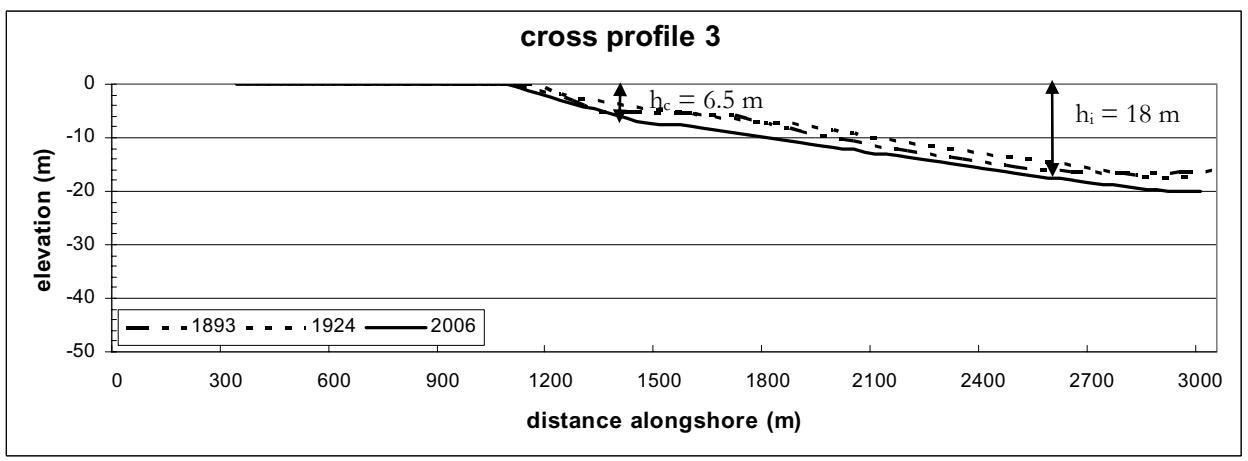

(c)

Figure 4.3: Shoreface profiles of the northwest coast of Banda (1893 and 1924) and after (January 2006) the tsunami on 26 December 2004. 
The availability of mobile sediments transported at the lower and upper shoreface profiles are also determined by the hydrodynamic conditions under the representative wave climate, which are important in the morphological development after the tsunami. Wave actions and currents which are more active in sediment transport at the nearshore (upper shoreface) eventually shape the upper shoreface profile into a concave shape; i.e., a typical profile of sandy coasts. Therefore, it is reasonable to calculate the littoral cell boundaries in such a coastal cell by using formulas applied for coastal processes for common sandy coast (e.g. CERC formula in Equation (4.4)).

\subsubsection{Analysis of historical shoreline evolution and the intermittent forcing factors}

The shoreline position changes in this study were derived from old topographic maps (1898, 1924, 1944 and 1978) and satellite images (1967, 1989 and 2000); the details are displayed in Table 4.2. The shoreline positions on the topographic maps were drawn on the basis of the high tide shorelines. On the satellite images, the shoreline position is the high-water line, which is determined from the discernable change in colour, texture, or composition of the beach, reflecting the maximum run-up of recent high tides.

Table 4.2: Spatial data sources for shoreline delineation

\begin{tabular}{cccc}
\hline Data source & Date / Time & Spatial scale / Resolution & Source \\
\hline Topographic maps & 1898 & $1: 20000$ & KITLV Amsterdam \\
\cline { 2 - 4 } & 1924 & $1: 50000$ & KITLV Amsterdam \\
\hline Satellite images & $05 / 06 / 1967$ & $2.0 \mathrm{~m}$ pixel resolution & KeyHole-7 / USGS \\
\cline { 2 - 4 } & $23 / 03 / 1989$ & $30 \mathrm{~m}$ pixel resolution & Landsat TM / ITC \\
\cline { 2 - 4 } & $08 / 03 / 2000$ & $30 \mathrm{~m}$ pixel resolution & Landsat ETM / ITC \\
\cline { 2 - 4 } & $01 / 04 / 2008$ & $2.5 \mathrm{~m}$ pixel resolution & IKONOS / crisp \\
& & NUS catalogue \\
\hline Photogrammetric & June 2005 & $0.5 \mathrm{~m}$ contour interval & NORAD survey / \\
topographic map & & & JICA / SIM Centre \\
& & & - BRR NAD \\
\hline
\end{tabular}

Figure 4.4 displays the pairs of shoreline positions of two consecutive years. Figures $4.4 \mathrm{a}, 4.4 \mathrm{~b}, 4.4 \mathrm{c}, 4.4 \mathrm{~g}, 4.4 \mathrm{~h}$ and $4.4 \mathrm{i}$ show the shoreline evolution between 1898 and 2000 at the Lambadeuk coast (see location also in Fig. 1.1), the southwest section of the Banda Aceh coast. This coastal region is influenced by tectonic subsidence (tectonically unstable coastal section). Figures 4.4d, 4.4e, 4.4f, 
$4.4 \mathrm{j}, 4.4 \mathrm{k}$ and 4.41 display the shoreline evolution of the same periods at the Kuala Gigieng coast (see location also in Fig. 1.1), a tectonically more stable coast at the northeast. The characteristics of the geomorphic settings of both coastal sections have been discussed in more detail in Chapter 2 .

Table 4.1 displays the record of tsunami recurrences with different validity. It specifies the tsunami events that occurred at locations from where any tsunami waves would have propagated towards Banda Aceh coast. Combined with the morphological changes at the coastal sections, this table points to evidences and indications of the occurrence of tsunamis in the first half of the past century. The probability of occurrence of these intermittent forcing factors is relatively high. It suggests that the return period of tsunami occurrence may be in a range of 20 to 30 years, albeit of varying magnitude. This gives the probability of a tsunami occurring in the region between $0^{0}$ to $17^{\circ} \mathrm{N}$ and $92^{\circ}$ to $100^{\circ} \mathrm{E}$ actually hitting the northwest coast of Banda Aceh at 9/26. The estimated annual probability of tsunami occurrences at Banda Aceh ranges from 5/200 to 9/200 or approximately from $1 / 40$ to $1 / 20$, respectively. This means that on average we can expect 2 to 4 tsunami events per century to occur, which means each generation could experience a tsunami!

Significant changes of the coastal morphology of Banda Aceh coast as shown in Figure 4.4 suggest that the small tsunami events listed in Table 4.1 are associated with these changes, particularly within the period between 1898 and 1978. Although most tsunami events in the past century were substantially smaller than the one that occurred on 26 December 2004, their impact on the shoreline morphology remains significant, as displayed in Figure 4.6.

In 1907, an earthquake with magnitude of $\mathrm{M} \sim 7.6$ occurred at $2^{\circ} \mathrm{N}, 95^{\circ} \mathrm{E}$ near Simeulue Island at the west coast of Aceh (see location in Figure 4.1). The tsunami and its destruction of the Simeulue Island coasts are well-preserved in the islanders' memories through story-telling from generation to generation by local witnesses and survivors (called 'smong stories'). Figure $4.4 \mathrm{a}$ and $4.4 \mathrm{~d}$ shows the shoreline configurations of 1898 and 1924. In the topographic map of 1924, 17 years after the tsunami of 1907, Ulee Lheue barrier island appeared to have been breached near its tip. We argue that the breaching is related to the earthquake in 1907. The climatic condition appeared not to be the cause of this breaching because the equatorial position of Indonesia shelters it from tropical cyclones that 

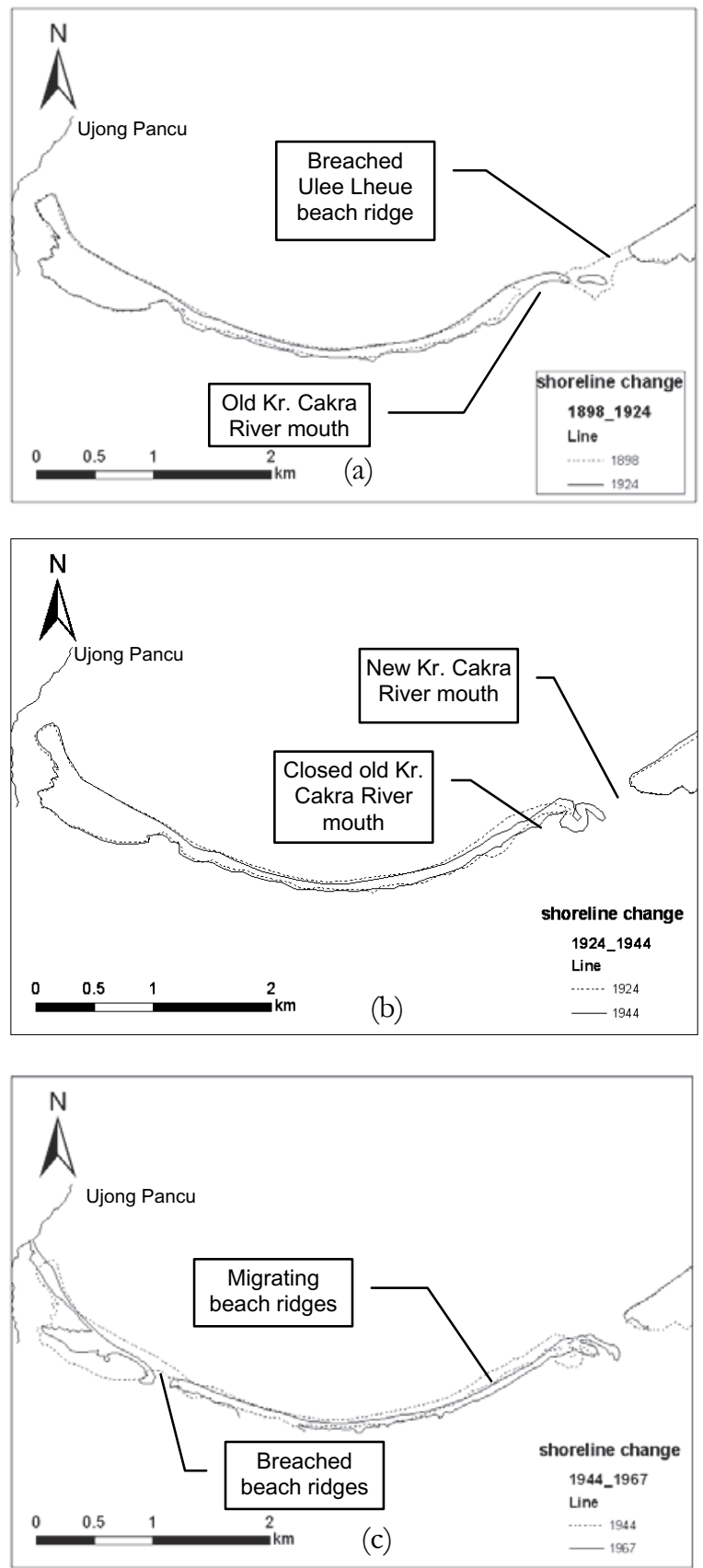

Figure 4.4: (a,b,c) Shoreline evolution between 1898 and 1967 at the Lambadeuk coast, the tectonically unstable coastal section. 

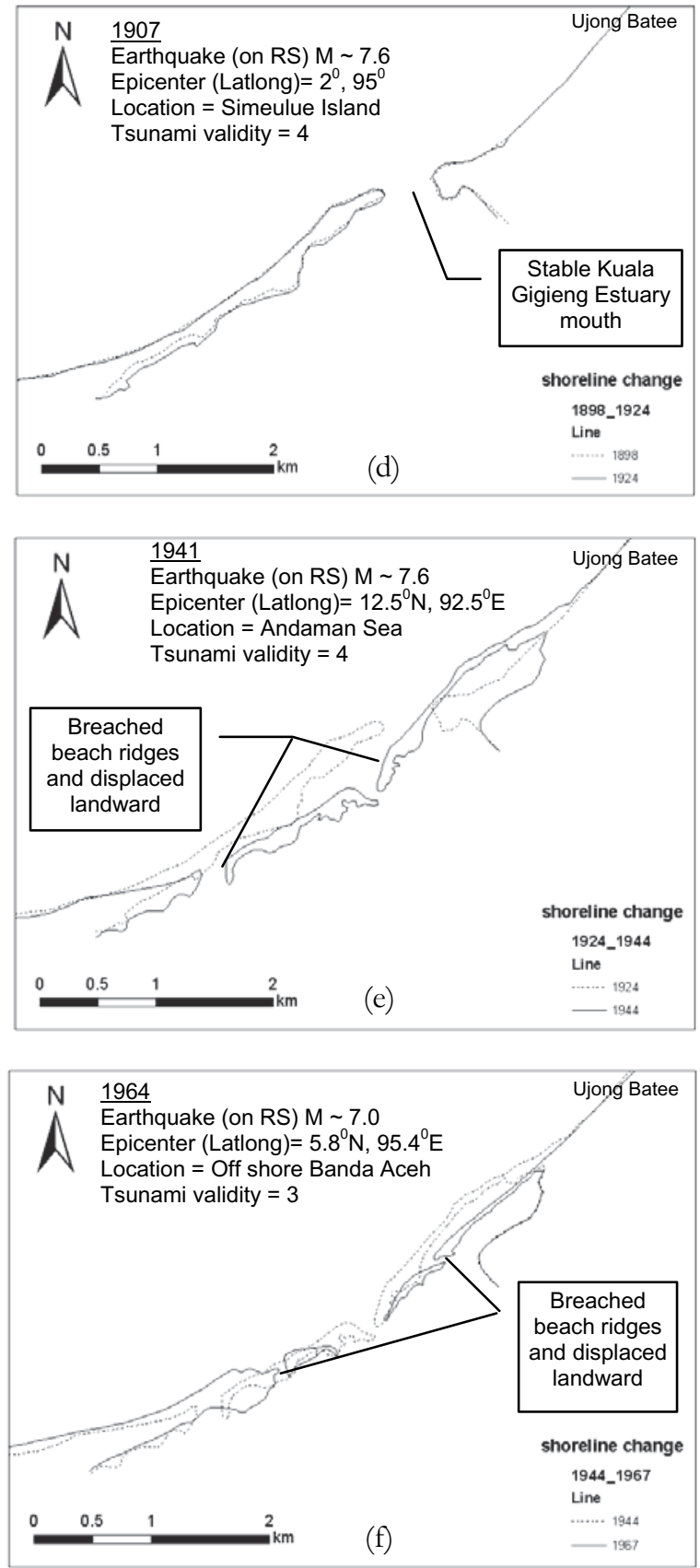

Figure 4.4: (d,e,f) Shoreline evolution between 1898 and 1967 at the Kuala Gigieng coast, the tectonically stable coastal section. 

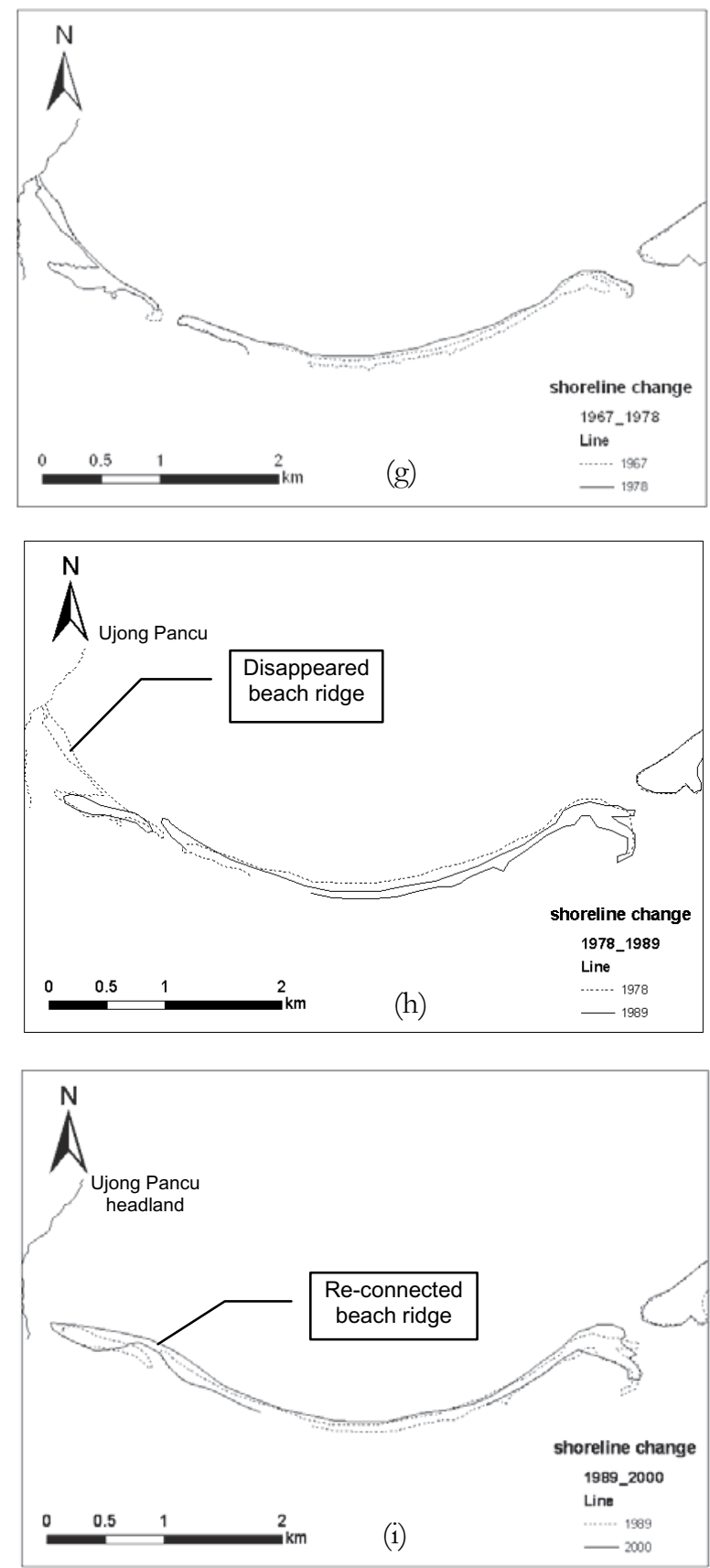

Figure 4.4: (g,h,i) Shoreline evolution between 1967 and 2000 at the Lambadeuk coast, the tectonically unstable coastal section. 

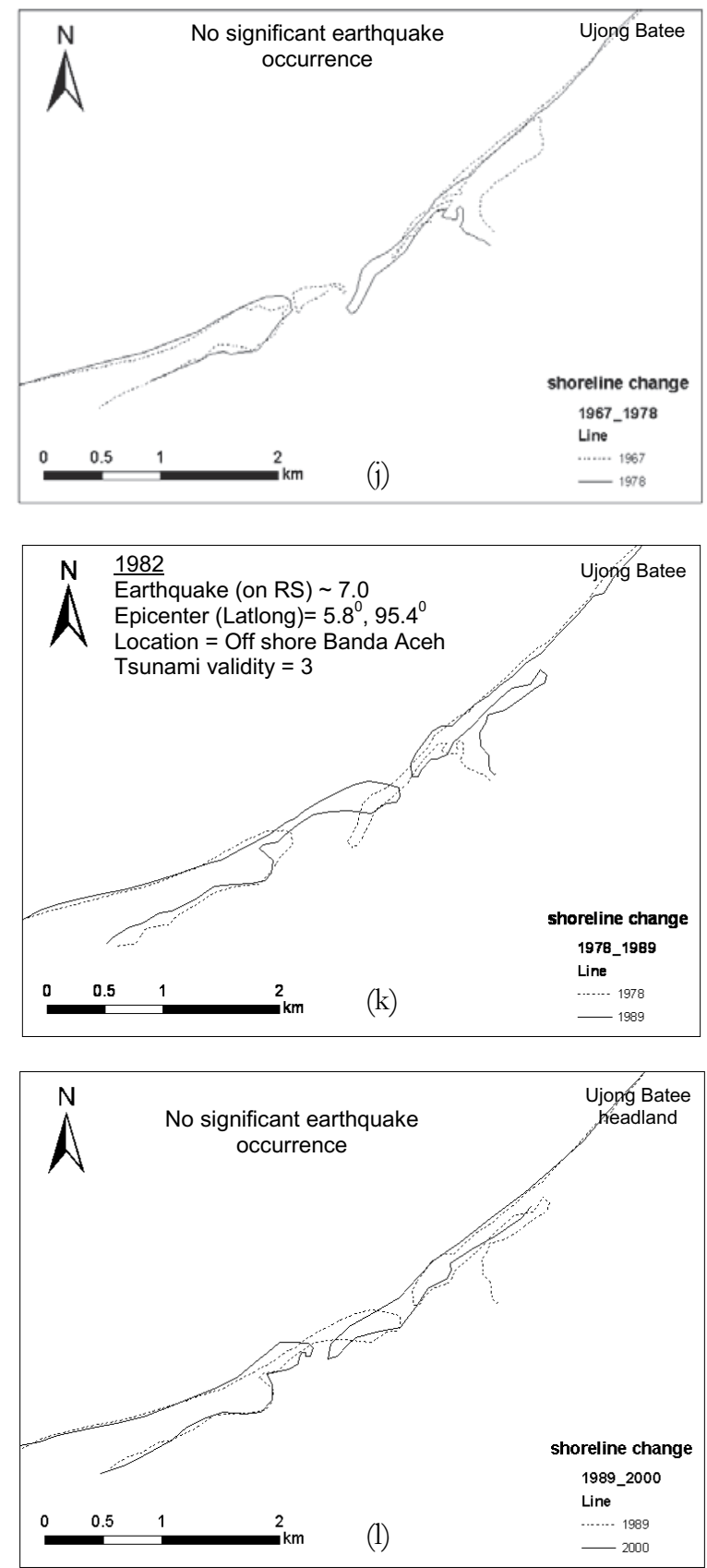

Figure 4.4: (j,k,l) Shoreline evolution between 1967 and 2000 at the Kuala Gigieng coast, the tectonically stable coastal section. 
often devastate the Philippines and the coastal zone of Western Australia. This means, it is unlikely that the breaching occurred due to storms or hurricanes. As the breached portion of the coast is located near the axis of the SFS fault zone (see Chapter 2) this suggests that the other forcing factors, most probably the earthquake or tsunami, may have caused the change.

Table 4.3: Shoreline change rates at Kuala Gigieng coast (cell 2 in Figure 4.4) in the past century

\begin{tabular}{cccc}
\hline Period & Number of years & $\begin{array}{c}\text { Shoreline change rate } \\
\text { (m/event) }\end{array}$ & Comment \\
\hline $1898-1924$ & 26 & 0 & Tsunami in 1907 \\
\hline $1924-1944$ & 20 & -27 & Tsunami in 1941 \\
\hline $1944-1967$ & 23 & -2.2 & Tsunami in 1964 \\
\hline $1967-1978$ & 11 & +2.7 & No tsunami \\
\hline $1978-1989$ & 11 & +1.0 & No tsunami \\
\hline $1989-2000$ & 11 & +1.5 & No tsunami \\
\hline
\end{tabular}

In 1941, another tsunami was recorded (with high validity, see Table 4.1) in association with an earthquake occurring in the northern Andaman Sea $\left(12.5^{\circ} \mathrm{N}\right.$, $\left.92.5^{\circ} \mathrm{E}\right)$. It generated a tsunami throughout the Andaman Sea and Indian Ocean and the wave height was of 0.75 to $1.75 \mathrm{~m}$ at eastern India. It was estimated that 3000 to 5000 people were killed in Sri Lanka and on the east coast of India (Pararas-Carayannis, 2005). Local newspapers incorrectly reported that the deaths and damage were caused by a storm surge, while meteorological records do not support the occurrence of storms during that period (Murty, 1984). Although there was no report of a related tsunami to have hit Banda Aceh, the morphological changes of the shoreline on historical maps suggest the northwest coast of Banda Aceh, located about $830 \mathrm{~km}$ south of the tsunami excitation location, to have been strongly affected by the 1941's tsunami event. A typical rough wave climate, if at all occurred in Banda Aceh, would have been unable to create such high storm surges to change the coastal morphology significantly as shown in Figure 4.4e. The longstable sand spit in the Kuala Gigieng estuary was completely removed by this tsunami event. Interestingly, the tectonically unstable coast such as Lambadeuk coast in Figure 4.4b appeared to be less affected compared to that occurred at the tectonically stable Kuala Gigieng coast in Figure 4.4e. This explains that geomorphic settings and sediment characteristics over which propagated tsunami waves could determine the degree of the coastal morphology destruction. In 1964, the coast of Banda Aceh seemed to be hit by another small tsunami (Fig. 4.4c and 
4.4f). It was triggered by the earthquake of $\mathrm{M} \sim 7.0$ of which the epicentre was at $95.4^{0} \mathrm{~N}, 5.8^{0} \mathrm{E}$, or just north of Weh Island, north of Banda Aceh. Assuming similar conditions as in 1941 (i.e. no sufficient power of storm surge in this region), the impact of this small tsunami on the coastal morphology is revealed by the breaching of newly developed beach ridges.

An interesting morphological development of the Banda Aceh coast occurred between 1978 and 1989. A remarkable change of coastal morphology occurred at Lambadeuk, southwest Banda Aceh coast (Fig. 4.6h), where no earthquakes leading to tsunamis had occurred in the region since 1964. The beach ridge of late Holocene (see explanation in Chapter 2) connected to the Ujong Pancu headland at the west end of the coast had disappeared, while in contrast, on the adjacent Kuala Gigieng coast of the northeast, the sand spit grew progressively along the shore.

McKinnon (1988), the first to investigate the archaeological artefacts at this location. He suggested localized tectonic subsidence in the vicinity of the SFS fault zone (Fig. 1.1) appeared to be dramatically evident at Lambadeuk. This was based on the submerged rectangular structure (Fig. 4.5b) which, in fact, was a former mosque foundation than remained visible underneath the water in an aerial photograph of 1978. He compared this situation with that was reported by Snouck Hurgronje of earlier 20th century, which suggested not only that the shoreline receded some 150 to $200 \mathrm{~m}$ over the past eighty years (1898 to 1978), but also a sunk of the coast at least two to three meters in the same period. These are comparable to the rate of 1.9 to $2.5 \mathrm{~m} /$ year and 0.03 to $0.04 \mathrm{~m} /$ year for the shoreline retreat and land subsidence, respectively. He was also informed that the location of the village of Lambaro (i.e. the former beach in front Lambadeuk) had been moved further inland three times in the last 60 years towards 1942, suggesting a sequential land subsidence occurrence.

We verified the changing situation by comparing the old topographic maps of 1898, 1924, 1967, 1978 and 1989 (Table 4.2, Fig. 4.4 and 4.5b). We found that there was not much different in the morphology of the southwest-end portion of the beach ridge of Lambadeuk (Fig. 4.5b) in the map of 1898, 1924, 1967 and 1978, although the sub-aerial portion of the beach ridge decreased. However, the map of 1989 shows the significant change of morphology, where the southwest-end portion was completely disappeared (Fig. 4.4h). We argue that this disappearance occurred suddenly as the effect of land subsidence associated with the earthquake of magnitude of $\mathrm{M} \sim 7.0$ in 1982. This 
earthquake's epicentre was located in the vicinity of the SFS in front of the northwest coast of Banda Aceh $\left(5.7^{\circ} \mathrm{N}\right.$ and $\left.95^{\circ} \mathrm{E}\right)$.

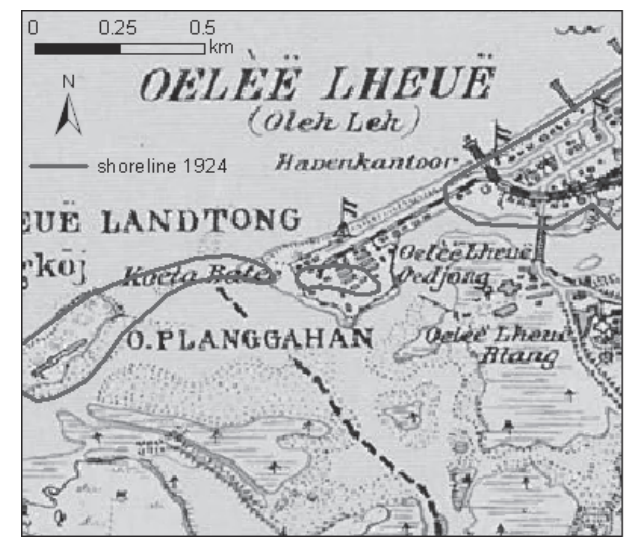

(a)

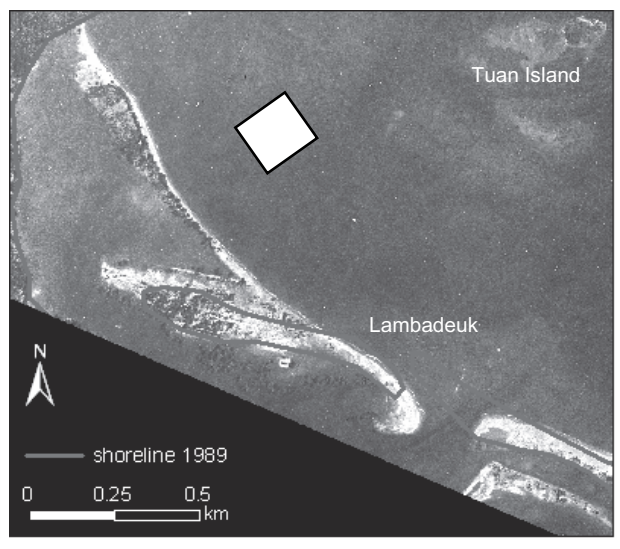

(b)

Figure 4.5: Remarkable shoreline changes in the past century at some locations along the coasts. (a) Shoreline changes between 1898 and 1924 at Ulee Lheue; (b) shoreline changes between 1967 and 1989 at Lambadeuk, southwest coast of Banda Aceh. The square at the sea side denotes the building foundation (mosque) according to McKinnon (1988) which was submerged during the corresponding period. Details about map resources can be seen in Table 2.1.

The disappearance of the beach ridge of Lambadeuk was irreversible accordingly. As can be seen in the subsequent development since 1989, the remnants of the beach ridge were inter-connected again but did not reach to Ujong Pancu. So, a new inlet was formed at the location of the disappeared beach ridge (Figure 4.4i). This suggests tectonics have played a role in the morphological development of the coast in the past century, in the form of land subsidence. On the other hand, at the northeast coast, the sand spit at Kuala Gigieng seems to be well-developed since the earthquake of 1964 (Fig. 4.4j and 4.4k) until another earthquake which probably triggered tsunami (see also Table 4.1) in 1982 have caused another remarkable changes to the coastal morphology (Fig. 4.41). This strongly suggests that the earthquake of 1982 with magnitude of $\mathrm{M} \sim 7.0$ caused land subsidence on the tectonically unstable Lambadeuk coast and triggered small magnitude of tsunami that significantly affected the ongoing morphological development at Kuala Gigieng coast on the northeast. 


\subsection{Scenarios for future coastal development: coupling continuous and intermittent forcing factors}

In order to understand the development of the coastal morphology in the longterm, it is important to know its variability on shorter time scales occurring within the long-term. In this particular case, the annual and decadal variability would characterize the trend of the coastal morphology on the time scale of a century.

In this section, sediment budgets are analysed by taking into account the transport rates of sediment components that enter or leave the selected littoral cells. Annual sediment budgets of before and after the tsunami of 26 December 2004 are first estimated, providing the rate of net residual transport under typical wave climate conditions (during two monsoonal seasons). Next, the rates of coastal morphological change (shoreline) due to tsunamis or land subsidence are introduced. The implications to the future morphological development based on different scenarios are discussed subsequently.

\subsubsection{Sediment budget analysis}

A sediment budget is a way of quantifying sediment transport process by identifying each process by which sediment enters or leaves an area, quantifying their corresponding volume of sediment to each process, and calculating the net effect. In principle, if more sand is transported away from a littoral zone than towards it, beach erosion results. An analysis of the sediment budget is used to determine the trend (i.e. erosional or accretional) of a considered coastal or littoral cell within the coastal system. A sediment budget is simply expressed in an equation as:

$$
\Sigma Q_{i}-\Sigma Q_{0}=\Delta V_{\text {cell }}
$$

where $Q_{i}$ is the quantity of sediment entering the littoral cell, $Q_{0}$ is the quantity of sediment going out of the littoral cell, and $\Delta V_{\text {cell }}$ is the quantity of sediment stored (positive) or depleted (negative) in the littoral cell. In the initial calculations, these parameters are estimated in units of cubic meter per year $\left(\mathrm{m}^{3} / \mathrm{yr}\right)$.

The calculation of the sediment budget is done on an annual basis. In this case, sediment budget components which result in residual net sediment transport rates that are significant for coastal process over a century were taken into account. These include the rates of net longshore sediment transport in the littoral zone, net 
onshore-offshore sediment transport (e.g. due to tsunami or storm), and cliff erosion. Beach fill and dredging are not applicable for the study sites. Figure 4.2 shows the sediment budget components applied in each studied cell.

\section{Net longshore and on-offshore transport rates}

Longshore transport in this study was calculated using the CERC formula (e.g. Short, 1999):

$$
Q_{\ell}=K \cdot c_{b} \cdot H_{b}^{2} \cdot \sin 2 \alpha_{b}
$$

Here, $Q_{\ell}$ is the rate of longshore transport in the littoral zone $\left(\mathrm{m}^{3} / \mathrm{yr}\right)$, $K$ is the proportionality constant $(0.015), c_{b}$ is the wave celerity in shallow water, which is proportional to the square-root of water depth on the breaker line and gravity acceleration, $H_{b}$ is significant wave height at breaking point (m), and $\alpha_{b}$, is wave angle at breaking point. The net effect calculated by the CERC formula (Equation 4) is considered as the maximum amount of sediment retained in or leaving the cell.

For a long time scale, a combination of the hydrodynamic process (e.g. wave orbital asymmetry) that provides an onshore transport bias to counteract the down slope effect of gravity over a steep shoreface profile slope is considered (Niedoroda, et al. 1995). The resulting net onshore transport gradient is estimated by Equation (4.5), (4.6) and (4.7) (Niedoroda, et al. 1995):

$$
Q_{\text {ons bore }}=-K \cdot \frac{P}{\rho g h}\left[e^{-\beta d} \cdot e^{-d . S}\right]
$$

where,

$$
P=\frac{\rho g H^{2} L}{16 T}
$$

This formula is used to represent the onshore sediment transport tendency from the combined action of waves and currents and the offshore effect of the bottom slope. Here, $P$ is the wave power as a function of $L$ and $T$, which are 
the wave length and wave period at the deep water, respectively. $\rho$ is seawater density, $\mathrm{g}$ is acceleration due to gravity, $\beta$ and $d$ are depth dependency coefficient and $s$ describes the bottom slope. The term has a negative sign because the processes it represents acts onshore, in the direction of the negative x-axis. The magnitude of this term decreases with increasing water depth or increasing bottom slope.

The parameter $\beta$ controls the rate at which the transport capacity decreases with water depth. For simplicity, we use an exponential decay to calculate this using Bowen's formula (Niedoroda, et al. 1995):

$$
\beta=\frac{1}{\sinh ^{n} k h_{i}}
$$

where $\mathrm{n}=3$ and $\mathrm{k}$ is the wave number.

Estimates of net sediment transport rates from the longshore and on-offshore sediment transport in the selected littoral cells (cell 1, cell 2 and cell 3 in Figure 4.2) at the Banda Aceh coast are discussed as follows.

The estimated rate of annual volume change (sediment budget) based on the CERC formula (Equation (4.4)) is assumed to represent the net transport capacity of the regular waves and currents in the littoral system throughout a typical year. In this case, we take into account significant waves and associated wave period which are representative for a hundred-year time scale and are acting on the upper shoreface (seaward boundary equals to $h_{c}=6.5 \mathrm{~m}$ ).

The typical wave climate at Banda Aceh has been described in subsection 4.2.1. Waves approach the Banda Aceh coast almost perpendicular (i.e. from the northwest direction) to the average shoreline position during the southwest monsoon (Fig. 4.2). In addition, the statistical analysis results of waves shows that the representative wave height for a hundred-year forecast is similar to that of the northeast monsoon (i.e. $1 \mathrm{~m}$ high), while the period is shorter (3 seconds). Therefore, wave climate condition from the northwest is not capable of inducing extensive longshore littoral transport. On the other hand, waves generated by the milder northeast monsoon enter the nearshore at high angles $\left(\alpha=70^{\circ}\right.$ to $\left.85^{\circ}\right)$ relative to the shoreline (Fig. 4.2). This may induce more intense longshore littoral 
transport. Table 4.4 shows the longshore sediment transport estimates for both monsoonal conditions.

The longshore transport rate estimates based on the CERC formula in Equation (4.4) are displayed in Table 4.4 for the pre- and post-tsunami conditions. The net longshore transport in a typical year was in a southwest direction. The difference between the pre- and post-tsunami conditions is in the shoreline orientation, which results in different longshore transport rates under the same wave climate.

Over the period of hundred years, the net offshore/onshore sediment transports may become increasingly important to the littoral transport system depending on the wave climate and the sediment availability. Therefore, sediments at the lower shoreface may still be movable by waves or currents. In cell 3, the lower shoreface may still consist of a thin layer of loose fine sand; nevertheless, the average wave climate could only have a very small amount of sediment being transported onshore. We estimate that the rate of the onshore transport at a depth of $\mathrm{h}_{\mathrm{i}}=18 \mathrm{~m}$ (see also profile 3 in Fig. 4.3) using Equations (4.5) and (4.6) in this particular cell is $3400 \mathrm{~m}^{3} / \mathrm{y}$ or only about two per cent of the total sediment transport rate in the littoral system.

Onshore transports were not taken into account for cells 1 and 2. This was because the lower parts of cells 1 and 2 contain very fine sediment (mud) that is not the littoral sediment and was in the form of a very thin layer over a quite steep slope associated with a submarine canyon. Thus, in this case offshore transport by gravity can be more important than the mass onshore transport by wave orbital asymmetry, which does not result in important onshore sediment transport in these cells. Moreover, off-shore transport may occur during a certain circumstances (e.g. rough waves). 


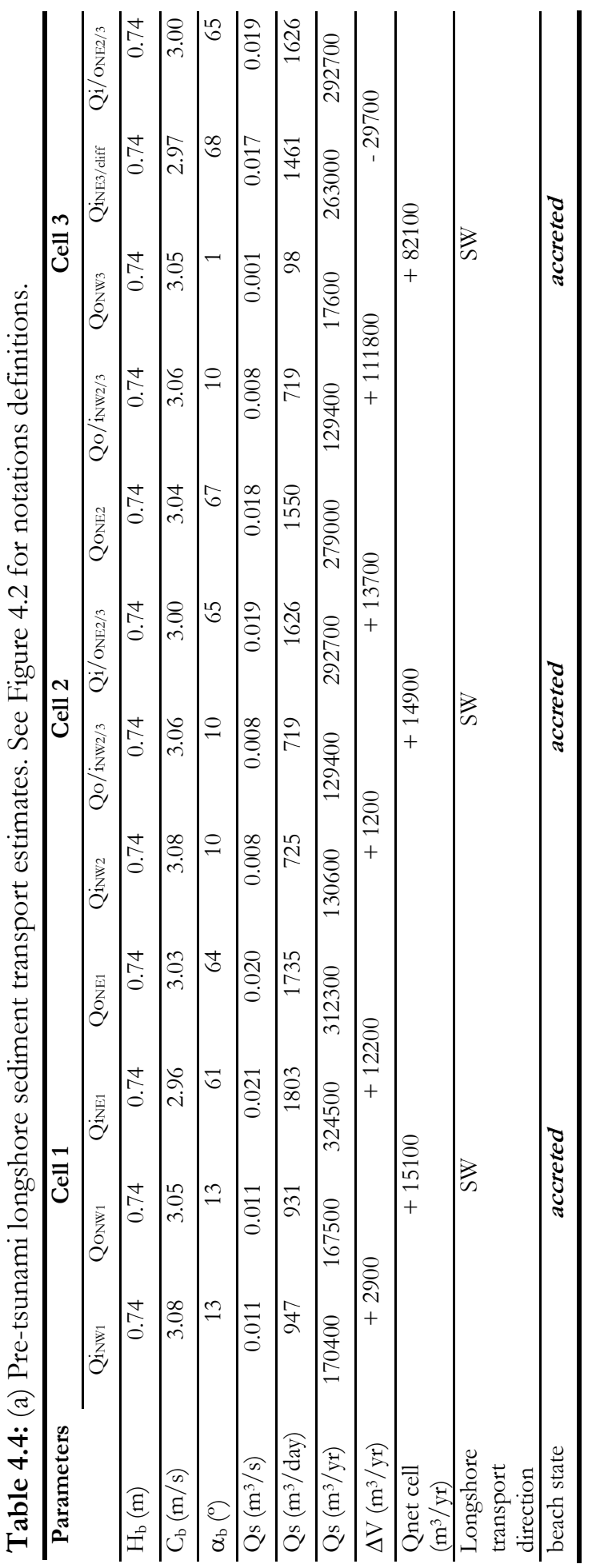




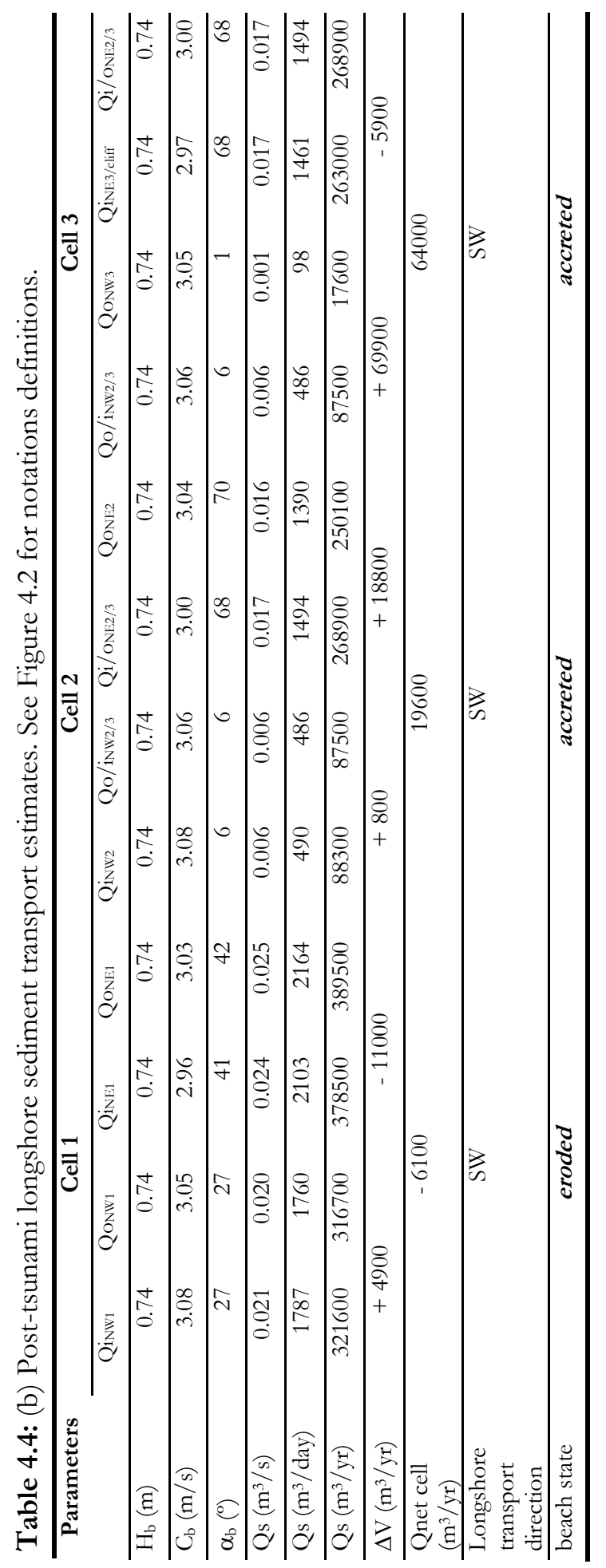


In both monsoons, during the occasion of storm waves which are typically not very high in this region, transient on-offshore sediment transport may be induced. The transported sediments may eventually return into the cell in the subsequent calm weather. Thus, this transient sediment transport may not be important within a hundred years time scale.

\section{Littoral source from cliff erosion}

As was described in subsection 4.3.2, the shoreface of the Banda Aceh coast has a considerably thin layer of moveable fine sand overlying the bedrock. Influenced by the significant wave height of $1 \mathrm{~m}$ combined with rather steep slopes at most parts, the lower shorefaces even lack of mobile sediments at some profiles (e.g. cells 1 and 2 in Fig. 4.2), especially after being affected by the December 2004 tsunami. It is perhaps reasonable to identify the Banda Aceh coast as a rocky coast as defined by Sunamura (1992); or as a sand-poor coastal environment as defined by Riggs, et al. (1995). The moveable sand layers in the littoral zone for each selected littoral cell may be considered as a common sandy beach by its erosional profile shape (concave profiles). The constraint is that there may be a lack of sediments entering the littoral zone and thus no important onshore transport.

For a rocky coast, the recession of coastal cliffs is essential (Sunamura, 1992). The tides in this case also are important for they would influence the water level which controls the wave action and hence the waves arriving at the cliff. Also, the tides may influence weathering and biological activities, but have not enough force to erode the cliff. The latter was not taken into consideration in the present study since we assumed that the weathering process would occur on a longer time scale, in the order of $10 \mathrm{~mm} /$ year over the period of two thousand years (Sunamura, 1992).

In considering the geomorphic settings of the Banda Aceh coast, waves coming from the northwest may induce a certain amount of cliff erosion (e.g. at Ujong Pancu headland which is shown in Fig. 1.1), but perhaps only feed as far as cell 1. Otherwise, the eroded cliff material may be deposited into the submarine valley associated with the Sumatran Fault System (SFS) further offshore (see Chapter 2) depending on the grain size. At the Kuala Gigieng coast on the northeast, the historical shoreline evolution reveals that after being affected by a small tsunami, this coastal section tent to accumulate sediments rapidly in the first decades after the event, e.g. after the tsunami of 1964 (Fig. 4.4j; period of 19671978 in Table 4.3). The littoral cells received abundant amounts of sediment 
inputs, most probably from the cliff erosion at the Ujong Batee (shown in Fig. 1.1), at least in the early adjustment process. In the last decades, we can also observe that the sand spit growth was very dynamic which indicates active longshore transport along this coast.

While the onshore transport rate is low in cell 3, and cliff erosion data are lacking in the present study, we assume that the cliff erosion rate may have been directly associated with the longshore transport rate entering the littoral system of cell 3. This means that any accretion or erosion tendency observed in littoral cell 2 or cell 3 is most probably associated with cliff erosion (or the lack thereof) at Ujong Batee.

\section{Net sediment transport rates of the intermittent forcing factors}

Tectonic subsidence and tsunami events are introduced in the sediment budget calculations as intermittent sediment budget components which are essential in altering the overall sediment budget estimates. Table 4.5 gives a summary of sediment transport rates in the littoral zone and the important rates of intermittent forcing factors that can be expected to present on the time scale of a century.

Table 4.5: Estimation of shoreline change rates due to different forcing factors.

\begin{tabular}{|c|c|c|c|c|}
\hline \multicolumn{2}{|c|}{ Forcing factors } & \multirow{2}{*}{$\begin{array}{c}\begin{array}{c}\text { Estimated rate of shoreline } \\
\text { recession due to different } \\
\text { forcing factors }\end{array} \\
-0.3 \text { to }+1.8 \mathrm{~m} / \mathrm{yr}\end{array}$} & \multirow{2}{*}{$\begin{array}{c}\begin{array}{c}\text { Affected } \\
\text { Coastal } \\
\text { section } 1)\end{array} \\
\begin{array}{c}\text { Stable / } \\
\text { unstable }\end{array}\end{array}$} & \multirow{2}{*}{$\begin{array}{l}\text { Methods of estimates } \\
\text { Sediment budget analysis }\end{array}$} \\
\hline$\stackrel{0}{0}$ & waves & & & \\
\hline . & $\begin{array}{l}\text { Eustatic sea- } \\
\text { level rise }\end{array}$ & $-0.6 \mathrm{~m} / \mathrm{yr}$ & $\begin{array}{l}\text { Stable / } \\
\text { unstable }\end{array}$ & Estimates by IPCC (2007) \\
\hline \multirow{2}{*}{ 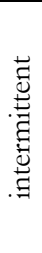 } & $\begin{array}{c}\text { Sudden } \\
\text { subsidence }\end{array}$ & - $46 \mathrm{~m} /$ event & Unstable & $\begin{array}{c}\text { Shoreline change } \\
\text { quantification / Estimates } \\
\text { (Chapter 4, this thesis) and } \\
\text { McKinnon (1988) } \\
\end{array}$ \\
\hline & tsunami & - 0.1 to $-27 \mathrm{~m} /$ event & $\begin{array}{l}\text { Stable / } \\
\text { unstable }\end{array}$ & $\begin{array}{c}\text { Shoreline change } \\
\text { quantification from maps } \\
\text { and satellite images }\end{array}$ \\
\hline
\end{tabular}

We calculated longshore and onshore sediment transport rates in cubic meter per year $\left(\mathrm{m}^{3} / \mathrm{yr}\right)$ units, while the rates of area difference of shoreline in 
history were measured in square meter per year $\left(\mathrm{m}^{2} / \mathrm{yr}\right)$. Both units were subsequently converted into meter per year $(\mathrm{m} / \mathrm{yr})$ to express the rate of longshore and onshore transports and area changes in the rate of shoreline position change. Abrupt changes due to intermittent forcing factors such as land subsidence are measured by $\mathrm{m} /$ event (Table 4.5 and 4.6). In order to accommodate the rate of shoreline change in time as the general parameter being used in this study, the conversion into $\mathrm{m} / \mathrm{yr}$ was done by assuming that the estimated rates are occurring in the littoral zone between the berm height ( $B$; averagely $1.5 \mathrm{~m}$ in height) and the closure depth $\left(b_{c}\right)$, which is defined as the active depth $\left(h_{a}\right)$ (Rosati, 1995):

$$
h_{a}=B+h_{c}
$$

The unit of $\mathrm{m}^{3} / \mathrm{yr}$ is subsequently also divided by the length of corresponding littoral cell.

Table 4.6: Estimation of sediment budgets within littoral cells after the tsunami on 26 December 2004 (see also Table 4.4b, 4.5 and Fig. 4.2)

\begin{tabular}{|c|c|c|c|c|}
\hline \multicolumn{2}{|c|}{ Components } & Cell 1 & Cell 2 & Cell 3 \\
\hline \multirow{3}{*}{$\begin{array}{l}\text { Continuous } \\
\text { forcing factors }\end{array}$} & $\Delta \mathrm{V}_{\text {cell }}\left(\mathrm{m}^{3} / \mathrm{yr}\right)$ & -6100 & +19600 & +64000 \\
\hline & $\begin{array}{l}\text { Rate of shoreline } \\
\text { change }(\mathrm{m} / \mathrm{yr})\end{array}$ & -0.3 & +0.5 & +1.8 \\
\hline & $\begin{array}{l}\mathrm{R}^{1)} \text { (sea-level rise; } \\
\mathrm{m} / \mathrm{yr} \text { ) }\end{array}$ & -0.6 & -0.6 & -0.6 \\
\hline \multirow[t]{4}{*}{$\begin{array}{l}\text { Intermittent } \\
\text { forcing factors }\end{array}$} & $\begin{array}{l}\left.\mathrm{Ts}^{2}\right) \text { (tsunami) } \\
\left(\mathrm{m}^{3} / \text { event }\right)\end{array}$ & -1500 & -150000 & -19000 \\
\hline & $\begin{array}{l}\text { Su3) (subsidence; } \\
\mathrm{m}^{2} / \text { event) }\end{array}$ & -231220 & No evidence & No evidence \\
\hline & $\begin{array}{l}\text { Ts (tsunami; } \\
\text { m/event) }\end{array}$ & -0.1 & -27 & -3.8 \\
\hline & $\begin{array}{l}\text { Su (subsidence; } \\
\text { m/event) }\end{array}$ & -46 & No evidence & $\begin{array}{c}\text { No } \\
\text { evidence }\end{array}$ \\
\hline \multicolumn{5}{|c|}{ Assuming the average upper shoreface profile slope being 0.01 . } \\
\hline \multicolumn{5}{|c|}{$\begin{array}{l}\text { Based on potential earthquake causing normal faulting (subsidence at cell 1) and tsunami event which } \\
\text { magnitude such that occurred in } 1941 \text { (cells } 2 \text { and 3). } \\
\text { Based on map calculation for the period of } 1978-1989 \text { indicating rapid subsidence (see also Figure }\end{array}$} \\
\hline \multicolumn{5}{|c|}{$\begin{array}{l}\text { Based on map calculation for the period of 1978-1989 indicating rapid subsidence (see also Figure } \\
\text { 4.6i). }\end{array}$} \\
\hline
\end{tabular}

Table 4.6 displays the recapitulation of the sediment transport rates estimated for the selected littoral cells at Lambadeuk coast (cell 1) and Kuala Gigieng coast (cells 2 and 3) after the tsunami. Estimated sediment gain and 
sediment loss due to wave action prevailing throughout a typical year (i.e. continuous forcing factors) within the littoral cells are denoted with positive and negative values, respectively.

\subsubsection{Scenarios for coastal morphological development in the next century}

The rate of shoreline changes caused by continuous and intermittent forcing factors displayed in Table 4.6 (i.e. the bolded numbers) were used in this section to analyse different combinations of coupling forcing factors of different magnitude that are probable to occur within a century. A conceptual model of shoreline change position was made in this study to describe the morphological development of the Banda Aceh coast occuring within a-hundred-year time scale in the future. The model was made based on our understanding about the probable magnitudes and frequencies of the intermittent forcing factors (i.e. tsunami and rapid subsidence) that interfere the long-term trend made by continuous forcing factors (e.g. waves and sea-level rise) during the development and the geomorphic settings of the three representative coastal cells (i.e. tectonically-unstable and stable coastal cells).

Different scenarios were, therefore, set up for future development of the coastal cells of the Banda Aceh coast. For simplification, in each scenario we assumed that the rate of shoreline change by waves or sea-level rise (i.e. continuous forcing factors) would restart with the same rate after an intermittent forcing factor (e.g. a tsunami event or subsidence) was introduced into the system. This is to avoid complication from the unknown detailed littoral processes leading to shoreline re-orientation and shoreface profile translations that may change the littoral transport regime, where processes are not yet incorporated in this study. The scenarios are made herein to give the rough approximations of the highlyschematized shoreline position change (e.g. trend and variability) by coupling continuous and intermittent forcing factors occur in the littoral system.

\section{Scenario 1 - Wave action, no tsunami, no subsidence}

In Scenario 1, the shoreline position trend in the next century was calculated based on the rate of sediment transport in each representative coastal (littoral) cell without taking into account the effect of sea-level rise and intermittent forcing factors. This scenario gives the first impression of the morphological state of the coast under 'normal' condition (e.g. eroding or accreting type of coast). 
Scenario 2 - Wave action, sea-level rise, no tsunami, no subsidence

In Scenario 2, the effect of sea-level rise was taken into account in the calculation of shoreline position trend by continuous forcing factor in the next century.

\section{Scenario 3 - Single tsunami and subsidence}

In Scenario 3, we assumed that the effect of sea-level rise was combined with a single tsunami event coinciding with land subsidence. Note that in any scenarios, land subsidence occurred in cell 1 only and this was combined with the effect of a tsunami, while sea-level rise and the effect of a tsunami occurred in cell 2 and cell 3 (see explanation in subsection 4.3.2). Here, we took the probable maximum rates of shoreline retreat due to land subsidence and tsunami that may occur within a hundred-year time scale based on our observation in the past century (see subsection 4.3.3 and also Table 4.3). The rate of shoreline retreat is $-46 \mathrm{~m} / \mathrm{event}$ due to the combined effect of land subsidence and tsunami occurred in cell 1 associated with the earthquake in 1982, and the shoreline retreat rate due to the tsunami in 1941 are $-27 \mathrm{~m} /$ event and $-3.8 \mathrm{~m} /$ event for cell 2 and cell 3 , respectively (see Table 4.6 and Fig. 4.6b and 4.6e).

\section{Scenario 4 - wave action, less frequent tsunami and subsidence occurrence}

In Scenario 4, we assumed that a couple of tsunami events which also coincide with land subsidence events that may occur in the future. The recurrence of such events of 30 years interval reasonably represents what actually happened in the last century.

Scenario 5 - wave action, frequent tsunami and subsidence occurrence

In Scenario 5, we used the same magnitudes of shoreline retreat rates as those of Scenario 3 and 4 , but the recurrence was increased to 20 years interval (more frequent). 


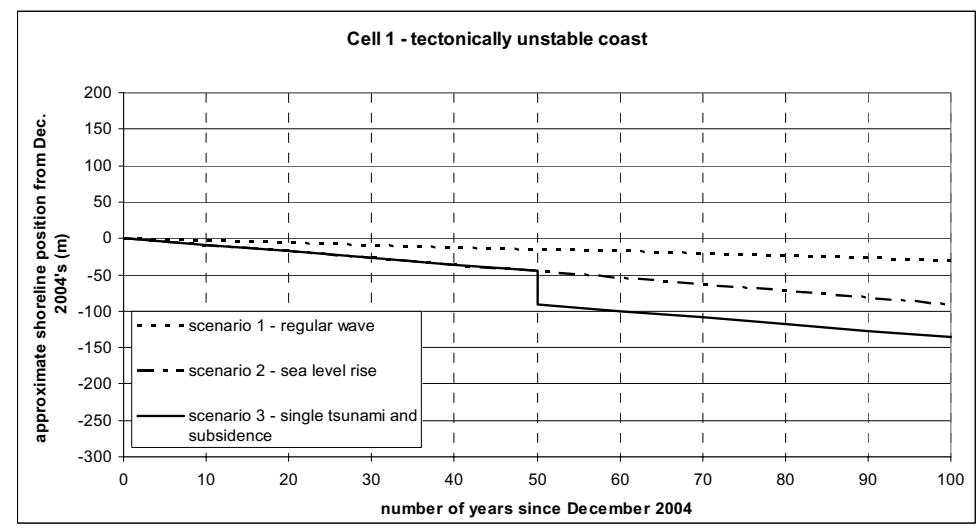

(a)

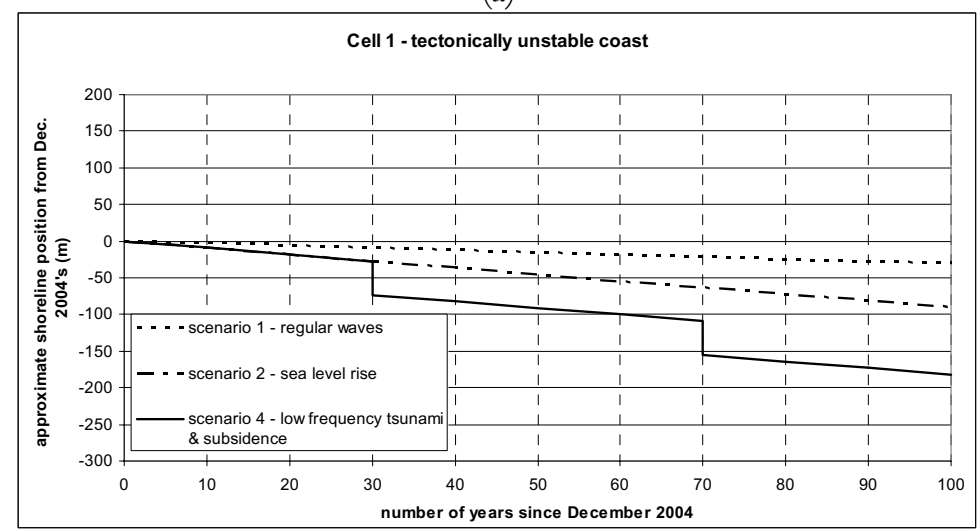

(b)

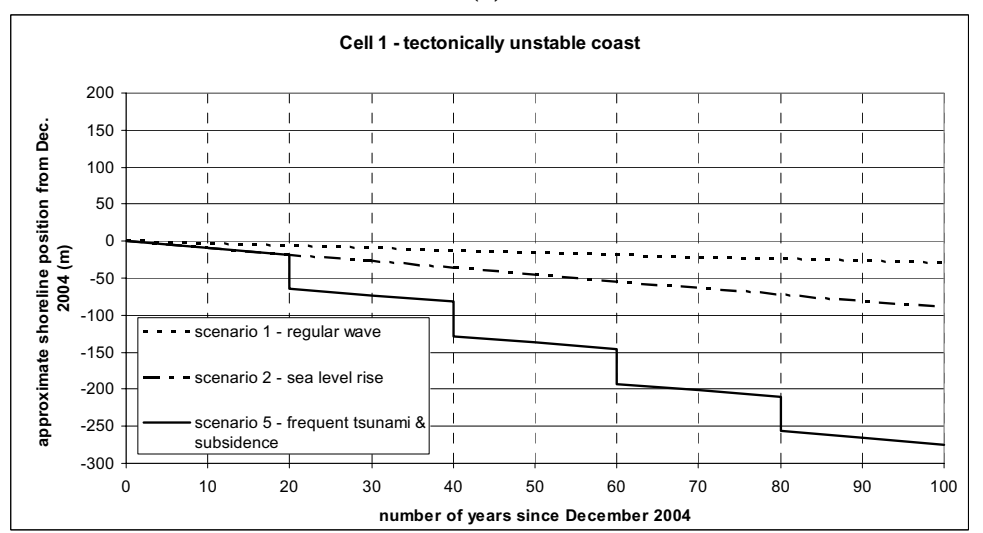

(c)

Figure 4.6: $(\mathrm{a}, \mathrm{b}, \mathrm{c})$ Shoreline position changes in the next century at the tectonically unstable and eroding coast; Lambadeuk, southwest Banda Aceh (cell 1). 


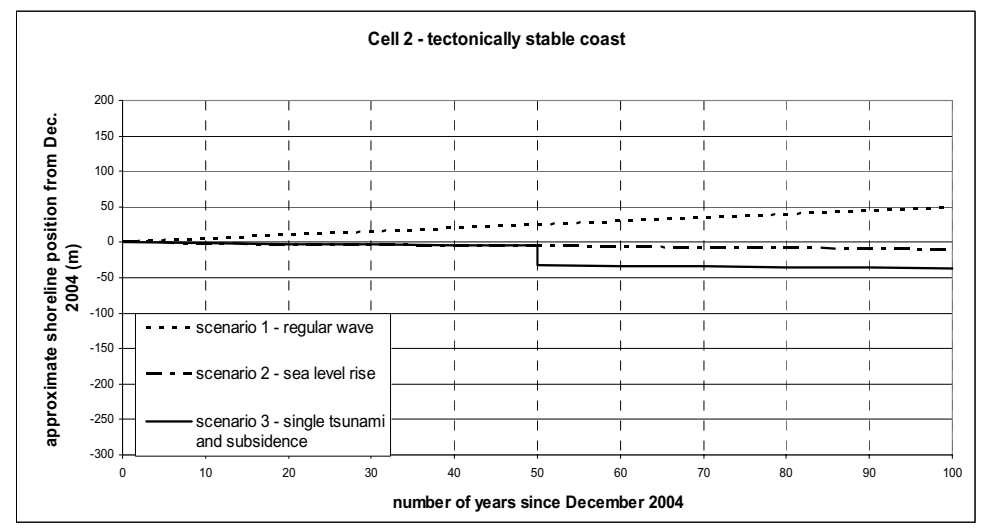

(d)

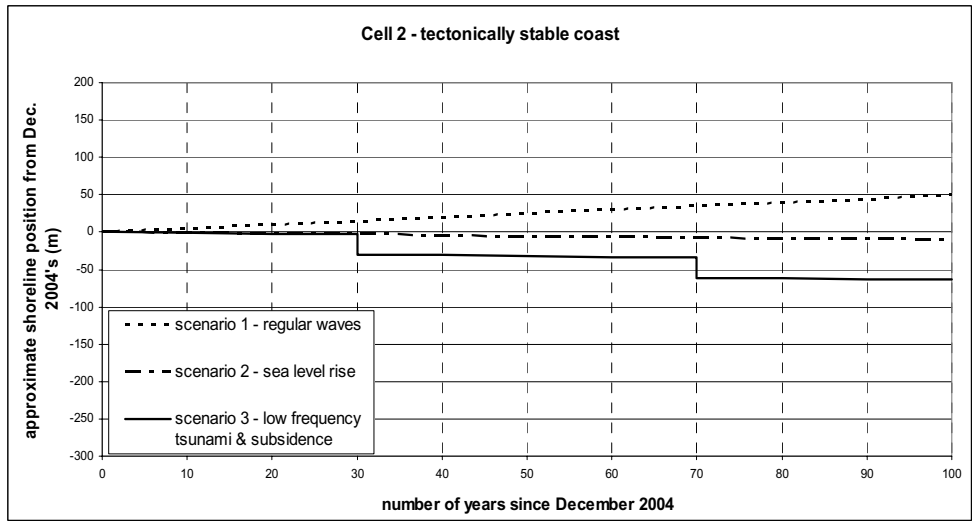

(e)

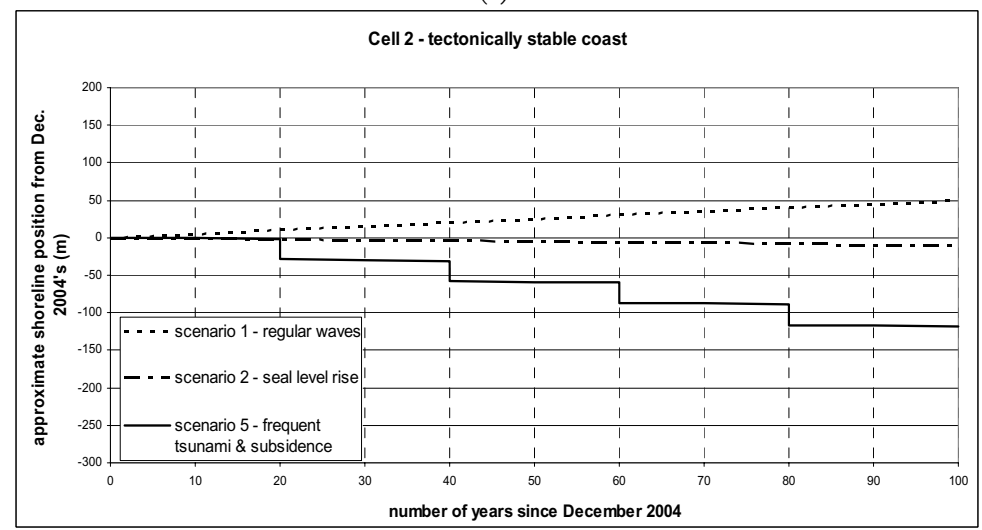

(f)

Figure 4.6: $(\mathrm{d}, \mathrm{e}, \mathrm{f})$ Shoreline position changes in the next century at the tectonically stable and accreting coast near an inlet; Kuala Gigieng, northeast Banda Aceh (cell 2). 


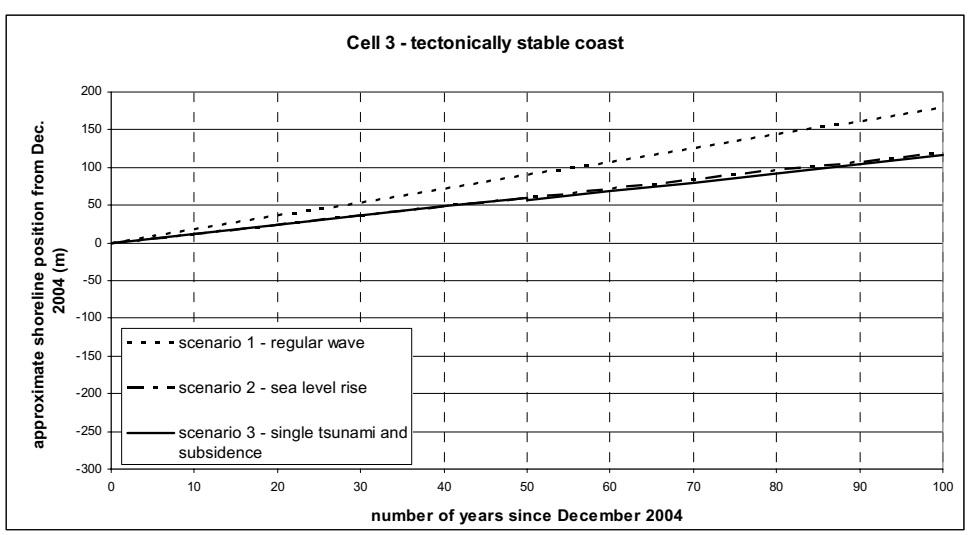

(g)

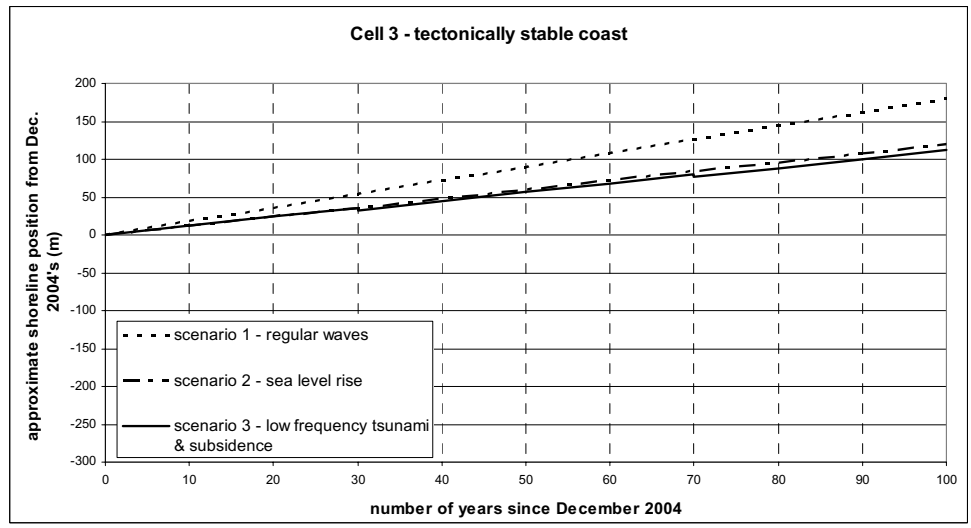

(h)

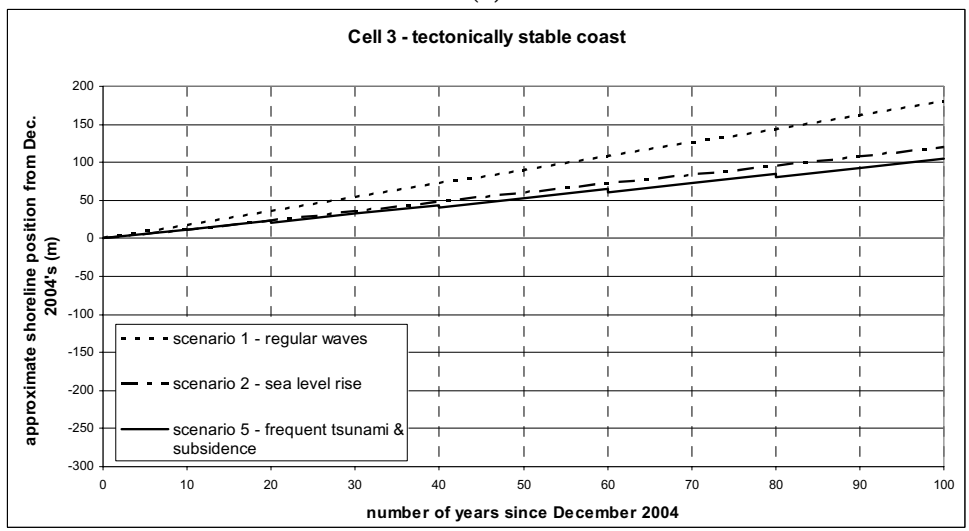

(i)

Figure 4.6: $(\mathrm{g}, \mathrm{h}, \mathrm{i})$ Shoreline position changes in the next century at the tectonically stable and accreting coast with Holocene beach ridges on the beach; Neuheun, northeast Banda Aceh (cell 3). 
All approximations of the shoreline positions based on the abovementioned scenarios are displayed in Figure 4.6, describing the approximate shoreline position change in the numbers of years since the December 2004 tsunami. Tables 4.5 and Figure 4.6 show that the rate of shoreline change can vary depending on the forcing factors that influence the morphological development of the coast. In a tectonically active region which is also a sand-poor coastal environment such as the one represented by cell 1 , the rate of shoreline retreat was the highest, particularly, when the scenario of frequent intermittent forcing factors was introduced in the system. The pre-dominant intermittent forcing factor in this cell is the influence of land subsidence (Table 4.5).

Cell 2 shows a lower rate of shoreline retreat compared to cell 1, although the effect of frequent intermittent forcing factors was considerably important to increase the retreat rate. However, in a scenario where the intermittent forcing factor was absent, the cell was actually advancing by sufficient sediment supply (see Table 4.4b). This eventually helps in reducing the rate of shoreline retreat due to the intermittent forcing factor; i.e. a tsunami in this case. In addition, the influence of eustatic sea-level rise in every cell was causing the increase rate of coastal retreat, but in general, the effect was much smaller than those of the land subsidence and tsunami.

Cell 3 is a coast facing a cliff and beach ridges play a dominant role in supplying sediment to its littoral zone and to adjacent cell2. Consequently, the effect of sea-level rise was much reduced by the relatively high rate of accretion, and the tsunami effect to the coast appeared as the breaching of beach ridges (e.g. Fig. 4.7) or eroded cliff.

\subsection{Discussions}

We discuss two points of interests: the coastal processes related to the geomorphic characteristics of the northwestern Banda Aceh coast, and the morphological development of a coast after a tsunami and land subsidence on the time scale of one hundred years. It is important to recognize beforehand the characteristics of the geomorphic setting and the forcing factors that are continuously involved in the coastal processes (e.g. wave climate conditions) to explain the impact and the expected development of the coastal morphology after being affected by intermittent forcing factors such as a tsunami and land subsidence.

The following sections will analyze different rates given by different forcing factors and how this may alter the morphological development of a coast within a 
hundred years by first learning the lessons of what happened in history, and second, adopt similar conditions for future development scenarios.

The Banda Aceh coast exemplifies a complex coastal system within only a relatively short coastline stretch $(25 \mathrm{~km})$, influenced by tectonic movement. Its complex morphology, i.e. the tectonically unstable convex shoreface at the Lambadeuk coast (cell 1) and the tectonically stable concave shoreface at the Kuala Gigieng coast (cell 2) and Neuheun coast (cell3), allows us to investigate the impact of land subsidence and tsunami on the coastal morphology and at the same time discriminate the effects on the two shoreface types.

\subsubsection{Tectonically unstable coastal region (cell 1; Lambadeuk coast)}

Coastal cell1 in Figure 4.2a represents the case to study the influence of tectonic land subsidence to the coastal morphology. As was analysed in subsection 4.3.3, a significant land subsidence event occurred in Lambadeuk (cell1), associated with the earthquake of M 7.0 in 1982 at the Banda Aceh coast. Furthermore, the coast experienced sequential land subsidence events in the past century which was associated with several large earthquakes (McKinnon, 1988). As a result, the morphology of the coast was dramatically changed.

No one can precisely predict the location of the next earthquakes and the risk it may pose for the coastal morphology. Assuming the probability of large earthquakes causing land subsidence may occur more frequently than those causing tsunamis, the coastal section associated with this forcing factor may always be subjected to significant shoreline retreat. Consequently, in a tectonically unstable region such as the Lambadeuk coast, the rate of sediment transport by the continuous forcing factors such as waves and tides cannot keep up with the rate of morphological changes due to the tectonic land subsidence.

The scenarios applied in coastal cell1 (Lambadeuk) described in subsection 4.4.2 and Fig. 4.6a, 4.6b and 4.6c show the effect to the shoreline retreat based on historical investigations providing the probability of tsunami and land subsidence events which acted upon the tectonically unstable coastal region of Banda Aceh (see section 4.2). Each figure shows shoreline change position (retreat) under the regular wave action (daily process), under the influence of sea-level rise as well as under the influence of the sequential tsunami and tectonic land subsidence effects (intermittent forcing factors).

Since the December 2004 tsunami, the shoreline of Lambadeuk coast further retreated (i.e. profile P1 in Fig. 4.3). A remarkable difference of the pre- 
and post-tsunami of December 2004 conditions is shown by the state of the coastal morphology from an accreting coast before the tsunami, to be an eroding coast after the tsunami, even if the intermittent forcing factors were not introduced yet in the system (Table 4.4). Estimates of the littoral transport rates of the preand post-tsunami in Table 4.4 explained that the changes of shoreline orientation relative to the incoming wave directions from the deep water $\left(H_{0}\right)$ during the southwest and northeast monsoons changed the wave-breaking angle in the surfzone, which determined the rate of the longshore sediment transport. The greater the wave-breaking angle to the shoreline, the greater the sediment transport along the shore.

The effect of sea-level rise increases the rate of shoreline retreat. However, this can further be exacerbated by the effect of land subsidence which may cause an irreversible shoreline retreat, especially in the sand-poor coastal environment. In all scenarios described in subsection 4.4.2, we assumed that the rate of shoreline retreat caused by tectonic land subsidence effect can be as remarkable as the land subsidence event that occurred due to the 1982 earthquake affecting the Lambadeuk coast, which equalled $-46 \mathrm{~m} /$ event. With increasing frequency of land subsidence of the same magnitude being set up in the scenario 5 , it is clear that the shoreline retreat by the end of the century can reach to almost one order of magnitude further than that due to a gradual sea-level rise.

\subsubsection{Tectonically stable coastal region (cells 2 and 3; Kuala Gigieng and Neuheun)}

In this section, we analyze the morphological development of the Banda Aceh shoreline under the influence of a tsunami. Historical records of tsunami events suggest that earthquakes that trigger tsunamis may happen in the recurrence interval of 20 to 30 years, on average. This cycle takes place within the 200 -years interval of the strain accumulation of the tectonic activities in the region.

In the cause of the December 2004 tsunami, the entire shoreface profile in front of this coast was eroded (i.e. profile P3 in Fig. 4.3). Despite this, after three years (e.g. in 2008), the Kuala Gigieng inlet and the breached beach ridges at Neuheun had already been closed by rapid new beach development (Figure 4.6), suggesting an accreting coastal state. Longshore transport estimates (Table 4.4 and $\Delta \mathrm{V}$ in Table 4.5) and historical maps of Kuala Gigieng (cell 2) and Neuheun (cell 3 ) in Figure 4.6 reveal that southwestward net sediment transport would be capable of retaining the surplus amount of sediment in cells 2 and 3 . 
Suppose we adopt a tsunami of 1941 to occur in the future, resulting shoreline retreat up to $-27 \mathrm{~m} /$ event and $-3.8 \mathrm{~m} /$ event in cell 2 and cell 3 , respectively (Fig. 4.6d,e,f and Fig. 4.6g,h,i), for the recurrence interval of 50, 30 and 20 years in scenario 3, 4 and 5. For a coastal cell with small accretion rate such as cell2, the accretion by regular waves cannot even compensate the shoreline retreat due the small tsunami events occur in a low frequency (e.g. once every 30 years; scenario 4 in Fig. 4.6d).

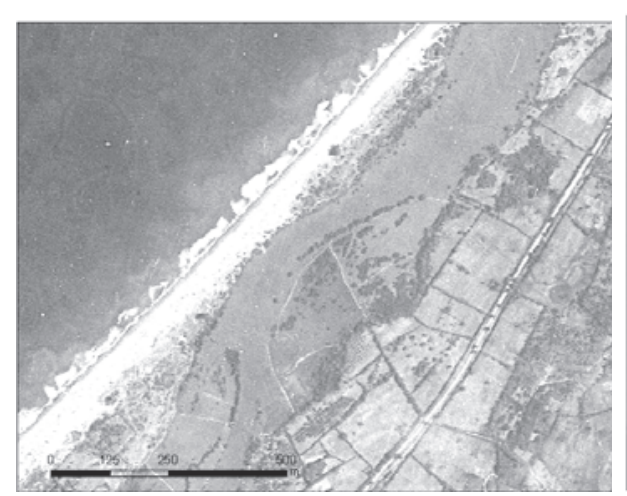

(a)

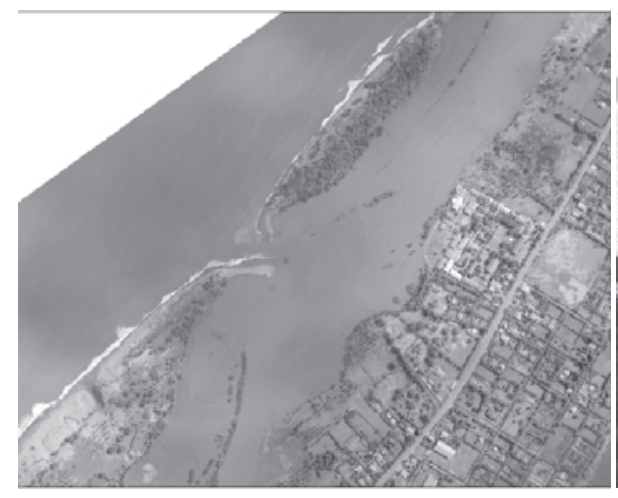

(b)

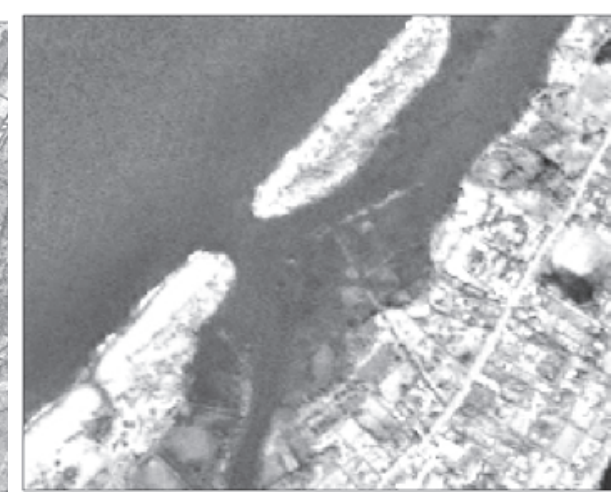

(b)

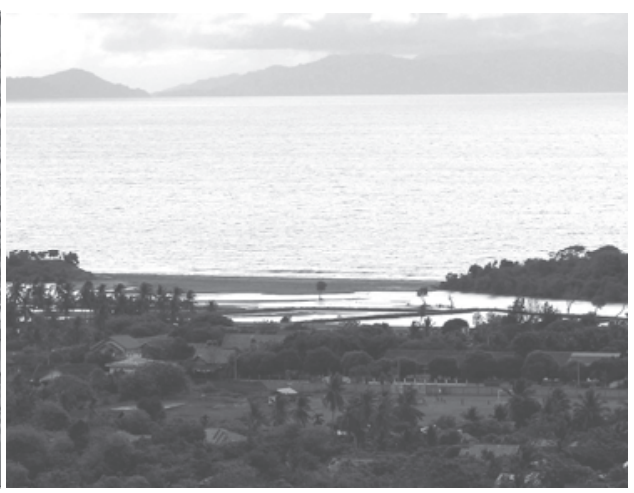

(d)

Figure 4.7: Coastal development accreting coast with beach ridges adjacent to Ujong Batee, at Neuheun, northeast of Banda Aceh coast (see also location in Figure 1): (a) The beach in 1967; (b) The breached beach situation, five days after the tsunami (30 December 2004); (c) Sand spits developed again five months after the tsunami (June 2005) and; (d) The beach was reconnected after three years and 5 months (May 2008). Image sources: (a) KeyHole-7/ USGS; (b) IKONOS/ ITC; (c) Ortho-rectified aerial photo by NORAD survey/ Bakosurtanal via SIM Centre - BRR NAD; (d) Photograph by Meilianda. 
Tsunami waves caused the shoreface profile P3 in Figure 4.3c at Neuheun coast (cell3) lowered down in the order of $1.0 \mathrm{~m}$. This new situation hampers the sediment to be restored to the littoral system by onshore sediment transport, providing much of sediment was re-distributed offshore by the tsunami. On the other hand, since the water depth increased, the wave height potentially increased accordingly. As a result, more intensive erosion could occur on the cliff or on the beach and beach ridges would invite a new source of sediment for the present littoral zone. As a result, a more than sufficient amount of sediment may be entering the littoral cells after such a sudden change of morphology, which is observed by the closure of inlets and re-connection of breached ridges by fresh sediments (e.g. Fig. 4.7d). Therefore, the effect of sea-level change as well as of a tsunami does not cause a severe shoreline retreat in Neuheun (cell 3 in Fig. 4.2). In fact the shoreline may be continuously advancing but accentuated with intermittent change of the coastal morphology, for instance, by the breaching of beach ridges or more cliff erosion. This eventually will bring about new sediment material in the subsequent coastal recovery.

\subsubsection{Implications of the tsunami and land subsidence effect on the sand- poor coastal environment}

In a tectonically active region such as the Banda Aceh coast, the trend of the coastal morphological development in a century may be altered by either a tsunami or tectonic subsidence (or uplift). Continuous forcing factors such as wave action, tides and eustatic sea-level rise may modify the coast in such a way that they lead to the long-term trend of the coastal morphological development, providing a quasiconstant rate of sediment transport. Intermittent forcing factors such as tsunami events or vertical tectonic movements leading to land subsidence or uplift, however, have a remarkable impact on the coastal morphology and its future development: they impinge on the long-term trend of coastal morphology. The long-term trend of coastal development may even be stopped, which also means that an equilibrium condition may not exist.

Sunamura (1992) described some considerations regarding the major contemporary geomorphic settings of shoreface which is comparable to the shoreface geomorphic setting of the Banda Aceh coast (i.e. sand-poor environment). In the extreme, such a sand-poor coast suffers erosion, which is an irreversible process and there is no way to restore a rocky coast once it has been eroded. On the other hand, beaches composed of unconsolidated material such as 
sand or gravel, or a mixture of these, undergo reversible change: erosion and accretion. The geomorphic settings of a shoreface very much depends on; (1) lithological factors, i.e. geomorphic settings and sediment characteristics which include the tectonics-related shoreface morphology, (2) weathering properties of rocks, (3) tides, (4) the degree of exposure to wave assault, and (5) the inheritance of minor relative changes in land and sea-levels. Even if nature fails to restore the beach, recovery is possible by means of, for instance, artificial nourishment.

Beach sediment of a rocky coast can either accentuate bedrock erosion by acting as an abrasive, or hinder it by working as a protective layer. A basic knowledge of the sediment movement under wave action and resultant beach changes (Komar, 1998) is therefore needed for a better understanding of such sand-poor coast erosion. The main factors to be considered in the development of such sand-poor coastal environment are, therefore, waves and the characteristic of the shoreface bed deposit. Erosion depends on the relative magnitude of the two.

In this study, the analysis of the morphological changes due to a tsunami at the Banda Aceh coast, either on the tectonically stable or on the non-stable one has been based on the understanding of its coastal morphology. The analysis of sediment transport rates at three different coastal littoral cells of tectonically stable and unstable coasts show that the amount of sediment being transported by the tsunami waves can be different from one location to another. This depends not only on the sediment deposits that form the geomorphic settings of the coast, but also on the resulting shoreline orientation as the impact of the tsunami and/or land subsidence. Kuala Gigieng and Neuheun coasts (cell 2 and cell 3) are tectonically stable coasts, while Lambadeuk coast (cell 1) is subject to vertical (and lateral) tectonic displacements. Despite being tectonically stable, Kuala Gigieng suffers from severe erosion by the tsunami, while low erosion rate occurred at the same time in Lambadeuk.

The knowledge of the rocky coast becomes crucial when it comes to studying its morphological development which is subjected to active tectonics and potential tsunamis. The process of coastal morphological adjustment after an event of land subsidence or a tsunami is influenced by the availability and the capability of the hydrodynamic condition of the coastal system to restore sediment into the littoral cell after having been re-distributed by the tsunami and also the capability of wave climate to provide new materials for the littoral zone, for instance, from the cliff erosion. This process is accompanied by the shoreline re-orientation as well as the shoreface profile adjustment. 
In a sediment budget of the littoral system, land subsidence may strongly affect the geomorphic setting of the coastal region, which acts as a sink due to sudden sea-level rise. On the other hand, the tsunami waves may affect sediment composition of the littoral zone by re-distribution and extraction of new materials, such as from cliff erosion or from beach ridge breaching, to the littoral zone. In a sand-poor environment, either case may cause irreversible shoreline retreat because the previous condition (which has changed so much) cannot be restored by littoral sediment transport under the continuous forcing factors, at least not in a period of one hundred years. This leads to the conclusion that a tectonically active coastal region is vulnerable to bias in discontinued morphological development. Therefore, the long-term trend of coastal morphological development can only partly be predicted. Finally, even though the recurrence of a huge magnitude of earthquake and tsunami event of December 2004 can be over a 700 years (see Chapter 2), which elapses the time scale of morphological development of the coast in this study (i.e. a century), it is clear that smaller magnitude of tsunami and also land subsidence may occur frequently in this coastal region. This study reveals that their magnitudes and frequencies are important to be taken into account in studying the dynamics of the coastal morphological development in the tectonically active region.

\subsection{Conclusions}

The Banda Aceh coast is a typical sand-poor environment on which a thin layer of littoral sand is perched to form narrow sandy beaches. The coast is located in the most tectonically active region in the world and is subjected to land subsidence and tsunami by the tectonic activities. In this study, we analyse the variability of the morphological development of the Banda Aceh coast expected in the next century (RQ3). The main conclusions derived from this analysis are described by answering the research questions as follows.

a) What are the frequency and magnitude of forcing factors involved in the coastal morphological development related to the earthquake and tsunami?

Answer: The rate of shoreline retreat caused by tectonic land subsidence effect was remarkable at the tectonically unstable part of Banda Aceh coast, which can be up to to $-46 \mathrm{~m} /$ event. Small magnitude tsunami events that occurred in the past century inferred a significant amount of shoreline retreat at the tectonically stable coastal section which can be up to $-27 \mathrm{~m} /$ event. These rates of sudden shoreline 
position change are relatively higher than that of the littoral transport by wave action and of the gradual sea-level rise in this region in this region.

b) How did the geomorphic settings and the continuous and intermittent forcing factors influence the morphological development of the Banda Aceh coast in the past century?

Answer: The Banda Aceh coast exemplifies a complex coastal system within only a relatively short coastline stretch $(25 \mathrm{~km})$, influenced by tectonic movement. Lambadeuk coast (cell 1) is subject to vertical (and lateral) tectonic displacements, while Kuala Gigieng and Neuheun coasts (cell 2 and cell 3) are tectonically stable coasts. Our analysis suggests that tectonics have played a role in the morphological development both the tectonically-unstable and -stable coasts of the coast in the past century. For instance, historical topographic maps suggest that the earthquake of 1982 with magnitude of $\mathrm{M} \sim 7.0$ caused significant land subsidence on the tectonically unstable Lambadeuk coast and at the same time triggered small magnitude of tsunami that significantly affected the ongoing morphological development at Kuala Gigieng coast on the northeast. The land subsidence and tsunami may cause significant shoreline re-orientation as well as the shoreface profile adjustment. More specifically, a land subsidence acts as a sink due to sudden sea-level rise. On the other hand, tsunami may affect the sediment composition of the littoral zone by re-distribution and extraction of new materials such as from cliff erosion to the littoral zone.

c) How will the geomorphic settings of the coast since the December 2004 tsunami and the forcing factors in different scenarios influence the morphological development in the next century?

Answer: Frequent earthquakes causing high probability of land subsidence and tsunami recurrence (i.e. 20 to 30 years) can be the worst scenario for development of such a tsunami-affected coastal morphology in the next hundred years. At an accreting and tectonically stable coast (e.g. Kuala Gigieng) the rate of advancing shoreline is halted due to the expected effect of sea-level rise, and can be further halted by the erosion caused by the intermittent tsunami events. On the other hand, at an eroding and tectonically unstable coast (e.g. Lambadeuk), the sea-level rise increases the rate of shoreline retreat, and can further be exacerbated by the effect of land subsidence which may cause an irreversible shoreline retreat, especially in the sand-poor coastal environment. 
This study reveals that their magnitudes and frequencies are important to be taken into account in studying the dynamics of the coastal morphological development in the tectonically active region. The damage caused by the probable recurrence of tsunami and land subsidence events to the coastal morphology within a century can be an order of magnitude greater than the effect of the wellknown sea-level rise due to global climate change, which is often considered important in modern coastal management practices. 


\section{Chapter 5}

\section{Discussion}

\subsection{Synthesis of the morphological development at the Banda Aceh coast}

In this chapter the scale of tsunami impact to the coastal morphology regarding the long-term morphological development against the short-term (sudden) impact of the tsunami and land subsidence in a coastal area. Tsunami and land subsidence cause sudden change in the coastal morphology. The scale of destruction due to these intermittent forcing factors depends on their magnitudes and frequencies of occurrence, and therefore is certainly important to be taken into account in studying the morphological development of the coast after the events.

Chapter 2 provides an insight to establishment periods of the morphological units on the modern geomorphic settings of the Banda Aceh coast preceding the tsunami of December 2004. The cascade model in Figure 2.9 summarizes the compilation of different forcing factors involved in shaping the morphology of the Banda Aceh coastal plain encompassing the geological to the decadal timescales, and the morphological units. Having this geomorphological insight, we learned that the impact of the huge tsunami of December 2004 on the morphology of Banda Aceh coast is an enormous natural intervention, that it suddenly changed the coastal morphology established since the Holocene.

Located in a tectonically active region, the Banda Aceh coast is always subjected to earthquakes leading to land subsidence and tsunamis. From the geomorphological interpretations in Chapter 2, it is noteworthy, that a tsunami of similar magnitude with the one on 26 December 2004 was likely to have occurred in this region in about $600 \mathrm{y} \mathrm{BP}$ (or ca. 700 years ago). Accordingly, one may consider such magnitude of a tsunami as a rare event in a human life time history, but certainly not unprecedented. Despite this, smaller magnitudes of tsunamis as well as land subsidence have occurred in the last two centuries which affected the Banda Aceh coastal morphology.

It is discussed in Chapter 4 that small-magnitude tsunami events occurred with a return period of 20 to 30 years in the last two centuries in the Banda Aceh region which was sometimes accompanied by land subsidence. The impact they caused is imprinted in the coastal morphology (shoreline change). It was estimated in Chapter 4 that the rate of shoreline position change due to land subsidence and 
tsunami is an order of magnitude higher (approx. $-46 \mathrm{~m} /$ event and $-27 \mathrm{~m} / \mathrm{event}$, respectively) than that by continuous wave action (i.e. $-0.3 \mathrm{~m} / \mathrm{yr}$ ) at the coastal stretch that has the most prominent change. This is definitely greater than the rate of projected sea-level rise due to global warming in the next century for this region (i.e. $-0.6 \mathrm{~m} / \mathrm{yr}$ ). The erosion due to tsunami and land subsidence may result in the complete removal of a coastal section, which suggests that shoreline retreat may be irreversible, particularly in the sand-poor coastal environment. This study reveals that even though their magnitudes and frequencies are considerably smaller than that occurred in December 2004, smaller, but more frequent tsunami and land subsidence events are important to be taken into account in studying the dynamics of the coastal morphological development in the tectonically active region in a century time scale.

\subsection{Short term development since earthquake and tsunami of December 2004}

In Chapter 3, two coasts on the northwest and west of Banda Aceh developed towards a contrasting behaviour within six months after the tsunami of December 2004. We analyze the abovementioned resulting situation in relation to our understanding about the inherited geomorphic settings of the coast by the longterm morphological development in history discussed in Chapter 2. By understanding the geomorphic settings of each coastal section and also the meteorological conditions in this region (e.g. wave climate conditions) it is possible to explain such different behaviours of morphological development of each coastal section.

At Ulee Lheue, the morphological adjustment process soon after the tsunami occurred in the form of further erosion of the shoreline as well as of the upper shoreface. After the tsunami, the shoreface profiles of unconsolidated sediments were greatly removed by the tsunami as displayed in Figure 2.7. Moreover, Ulee Lheue is also associated with a quite steep and narrow shoreface profile (i.e. P2) over which moveable sediment was very limited, even before the tsunami took action on it (i.e. sand-poor coastal environment). Such a shoreface condition, thus, cannot serve as a sediment source to feed the littoral zone. Sediments that were re-distributed by the tsunami further offshore, most probably would not return to the littoral system with this geomorphic constraint (i.e. steep slope and narrow shoreface). Also in this case, river-sediment supply and cliff erosion are not important in this coastal cell (see explanation in Chapter 4). 
At Lampuuk, on the other hand, sediment tends to return to the littoral system very quickly after six months. From our two consecutive fieldworks in June 2005 and August 2006, we observed that the inlet mouths were closed by relatively rapid sediment deposition, and beach berms or small dunes have been built up rapidly along the coast. We argue this rapid sediment regaining is closely related with the type of the geomorphic settings of the west coast which is apparently a sand-rich coastal environment where sediment supply in the littoral zone is sufficient and also with a wider and gentler slope of the shoreface corridor (see explanation in Chapter 3). To support this argument, we also observed the morphological development of Neuheun coast (Fig. 4.9 in Chapter 4) of the pretsunami situations (i.e. 1967) and three years since the tsunami (i.e. 2004, 2005 and 2008). In Chapter 2, it was explained that this coastal stretch is typically an accreting coast which has enough sediment supply (shoreface profile P5 in section 2.5.2 of Chapter 2). The sediment budget analysis in Chapter 4 suggests that the sediments in the littoral zone were supplied from the erosion of Ujong Batee cliff in this case. After the tsunami of December 2004, similar regaining sediment such as closed inlets and re-connected breached beach ridges were also captured on the Neuheun coast, at the northeastern portion of the Banda Aceh coast (see Figure 4.8 in chapter 4). From our geomorphological study in Chapter 2, we understood that both coastal sections have a type of coast with enough sediment supply (i.e. sand-rich coastal environment) that was apparently supported by a wider and gentler slope shoreface corridor.

The rapid re-gain of sediment on the west coast (Lampu Uk) seems to be comparable to the development of the sand-rich coastal environment after a hurricane. Morton et al. (1994) investigated that the first stage of response after Alicia, a category- 3 hurricane in a sand-rich beach environment lasted about one year, which involved shoreward sand migration, foreshore deposition, and rapid advancement of the berm crest. In time, the growth rate decreases as the shoreline and shoreface become smoothed under the wave action.

On the other hand, the Ulee Lheue coast apparently has a type of sand-poor coastal environment (Riggs, et al., 1995). For such a coast, we observed the littoral transport is highly dependent with erosion of the irregular shape of morphological units such as cliffs, beach face and beach ridges by tsunami waves. The Ulee Lheue coast (or Banda Aceh coast in general) rapidly adjusted its littoral morphology by re-organizing the chaotic shoreline of the eroded beach ridges and bumpy transient deposits due to tsunami wave actions. On the other hand, we also suspected that the ongoing shoreline retreat in this respect has partially to do with the effect of 
land subsidence. Consequently, the sediment transport rate under the normal wave action cannot keep pace with the rapid/sudden sediment transport rate, and therefore caused further shoreline retreat.

Overall, this led to the argument that the slope gradient and width of the shoreface in front of each coast control this contrasting behaviour. The littoral transport will require a transient adjustment of morphology which can be in the form of shoreline position re-orientation and the smoothening of the shoreface. Nevertheless, because of the severely eroded coasts due to tsunami and, to some extent, due to land subsidence this was not necessarily accompanied by the return of the shoreline to its pre-tsunami position.

\subsection{Influence of tectonic land subsidence and tsunami compared to the effect of climate change in future morphological development}

Long-term geomorphological interpretations in Chapter 2 and shoreline evolution in the past century in Chapter 4 are corroborated in this study to determine the extent of morphological destruction due to the earthquake and tsunami, to characterize the coastal geomorphic settings and sediment characteristics and to quantify the probable magnitudes and frequencies of earthquake and tsunami events in different time scale of interests. The combination of the three results can be used to further analyse the different behaviour of response and development of coastal sections with different geomorphic settings, such as tectonically stable/unstable coasts in combination with different littoral sediment transport regime (e.g. eroding or accreting littoral cells). With this information, the interaction between the shoreface morphology and the continuous forcing factors (wave action or sea-level rise) acting upon the specific littoral cells can be conceptually modelled in different scenarios assigned with different magnitudes and frequencies of the intermittent forcing factors (i.e. tsunami and land subsidence) as discussed in Chapter 4.

The complex geomorphic settings underlying the Banda Aceh coastal plain resulted from various processes in a long-term history ultimately determined the composition and texture of beach sediments of the modern coastal morphology. The coastal morphological evolution in the past century shows a remarkable variability in shoreline recession rates in decadal time scales (Fig. 4.6). Tectonics actively influences the morphological development of the coast, either directly by powerful earthquakes (land subsidence) or by the prominent tsunamis. All of these occurred in a course of strain-energy release process of the subducting 
zone of Indo-Australia plate underneath the Southeast-Asian plate. The maximum energy release was related to the earthquakes of high magnitudes $(>7.0$ on Richter scale) in history which in this region may occur on average once every two hundred years. Within this period, earthquakes with different magnitudes were associated with multiple land subsidence and tsunami occurrences. From historical data investigation, the frequencies and rates of shoreline change caused by land subsidence and tsunamis in the past century can better be understood.

It was shown in chapter 4 that particularly in the Indian Ocean region of the associated subduction zone, the region will suffer a repetition of tsunami events with the probability of occurrence every 20 to 30 years in average, disregarding their magnitudes. The magnitudes of these tsunamis were much less than that occurred in December 2004, may have been overlooked in history but historical data reveal their remarkable impact to the coastal morphology.

Based on this understanding, some scenarios for future development of Banda Aceh coastal morphology are analysed in Chapter 4. The scenarios are made herein to give the rough approximations of the highly-schematized shoreline position change (e.g. trend and variability) by coupling continuous and intermittent forcing factors occur in the littoral system. These scenarios show that the more frequent earthquakes, the higher probability of land subsidence and tsunami may occur. In any scenario, the rates of shoreline position change are relatively higher than that due to gradual sea-level rise in this region.

\subsection{Issues on uncertainty and methodology}

In general, the analysis of the coastal morphological development in this study was approached by an explorative method by utilizing multi-source spatial data consisting of satellite images, historical topographic maps, nautical charts and bathymetric data). This subsequently was combined with comprehensive literature in geomorphology, tectonics and sea-level fluctuations in the Andaman Sea Region (see Chapter 2). Geomorphological interpretation from the combined data sources was used herein as a proxy of inadequate in-situ data, for instance, geological surveys in the region describing the characteristics of geomorphic settings and sediments in the shoreface zone. This knowledge is required in forecasting the future development of the coast in different scenarios.

This approach inevitably invites the issue of uncertainty in this study. We identify two major sources of uncertainty in this study, which are defined as: 1) true uncertainty; 2) technical uncertainty. Rosati (2005) described that in coastal processes, 
significant contributors to a true uncertainty enter through natural variability which includes temporal variability, spatial variability and the unknowns of some certain processes or phenomena. In this study, we narrow the gap of knowledge through the geomorphological interpretation, quantification of magnitude and frequencies of tsunami and land subsidence occurrences and their effect to the variability of shoreline recession in the coastal morphology, which eventually contributes to reduce the true uncertainty. This is because for the first time in this study we are able to describe with a sufficient knowledge on the effect of the interplaying forcing factors, either continuous or intermittent, and the feedback given by the coastal morphology in a tectonically active region which is subjected to tsunami and land subsidence such as the Banda Aceh coast.

Considering the frequency of the recurrence of tsunamis irrespective of their magnitudes, we are able to find the correlation between the tsunami event records with some deviating morphological imprint of the shoreline in Banda Aceh in the past century (in chapter 4). Dominey-Howes, et al. (2007) argued that in some cases, normal tidal movements and floods associated with tropical cyclones have been erroneously listed as tsunami. Despite their effort, they overlooked the tsunami events in 1941 and 1964 that were correlated with the changes of coastal morphology of Banda Aceh (chapter 4); probably because the events merely gave a localized effect. The study of historical shoreline development in the past century in Chapter 4 has given a strong indication that the changes of coastal morphology in Banda Aceh in the first half of the past century were as the effects of the tsunami events in 1941 and 1964 (see Fig. 4.6 in chapter 4).

On the other hand, a technical uncertainty arises from the use of multisource of spatial data sets. In this case, the uncertainty comes from four sources: 1) from the spatial data resolution; 2) from the records of the earthquakes, their epicenters and the tsunamis; and 3) from the sediment budget estimations.

The shoreline position as the main parameter of morphological development in this study was extracted by digitizing topographic maps as well as satellite images of different measurements, methods, sensors and also spatial resolutions. Bathymetric data from different geodetic/bathymetric surveys methods were also used to generate Digital Elevation Methods (DEMs) for the vertical data. All data sources were processed within a Geographic Information System (GIS) and geo-referenced to a master map to have a common horizontal datum, projection, and coordinate system (for horizontal position), and also used a common elevation reference for vertical position. The digitized shorelines from these different data source have a potential horizontal error which ranges \pm 0.3 to 
$30 \mathrm{~m}$ depending on the spatial resolution of the satellite images, while the historical topographic maps produced from the colonial age expedition have a potential error of $\pm 6 \mathrm{~m}$. Recent bathymetric surveys using single-beam echosounder and GPS resulted estimates of vertical error of $\pm 0.1 \mathrm{~m}$. The uncertainty resulted from the DEMs generation and tidal reference was estimated to be \pm 0.5 to $2 \mathrm{~m}$. Despite this, we were able to capture the effect of small magnitude of land subsidence (Chapter 3) as well as able to discriminate the shoreline changes as the effect of intermittent forcing factors (e.g. due to tsunami and land subsidence) from those as the effect of continuous forcing factors (e.g. due to regular waves) and also to identify the corroboration of morphological units to a certain processes in the long-term history (e.g. beach ridges development related to the sea-level fluctuations in the Holocene in Chapter 2) with sufficient accuracy. This suggests such range of vertical or horizontal uncertainties are acceptable in this respect.

The research conducted in this thesis was done by compromising the lack of in-situ data, particularly to describe the geological aspects of the study area, with the needs to answer urgent questions regarding the coastal management and coastal safety for this tectonically active coastal area in future. The intention was to provide a framework of the better-understood morphological development of the coast in the past and in the present since the 2004 tsunami, and then to provide alternative scenarios of the development in future. The most factual reason of conducting the study in this way is that the Nanggroe Aceh Darussalam Province experienced a long-term insecurity problem since the independence of Republic of Indonesia in 1945. This situation prevented the authority (both local and national level) to coordinate field surveys (e.g. geological, coastal and other geophysical surveys) which regularly updated in the other provinces. This resulted in a longtime gap of knowledge about this area, particularly, in the morphological development of its coasts. Despite this, historical topographic maps, nautical charts and some geomorphological studies by the Dutch in the colonial era in the last centuries are of valuable archive to have an insight of the coastal morphology in the past.

Pragmatically, we support an argument stating that an elaborate level of parameterization in a coastal process study (e.g. results from elaborate data collections) may somehow lead to increase of uncertainty when the processes at play remains poorly understood (Cowell, et al., 1995). As the research in tectonotsunami is still young in age, we therefore emphasize the need to understand the tectonics phenomena leading to tsunami and land subsidence over the detailed degree of errors of spatial data integrations. This study attempts to reduce the 
uncertainty contributors by filling in as much knowledge gaps as possible. This is either by investigating the characteristics of the coastal system of interest, or the forcing factors that interplay. The explorative premise provides a proxy of the almost non-existent data sources (shoreface and beach sediment characteristics and geomorphic settings) and most importantly as a proxy of the non-exist explanation of the phenomena (e.g. the impact of tsunami and earthquakes to the coastal system).

By creating the framework of the morphological development for the past, present and future of the Banda Aceh coast, opportunities of further research is also created, for instance to validate the geomorphological interpretations by taking in-situ data and other field measurements. Therefore, to this end we argue that this thesis provides the most comprehensive study of the devastated coastal area due to the tsunami of December 2004 in from with respect to its coastal morphological development.

\subsection{Generalization and application of the present study}

An important remark from the scenarios of the future morphological development of the Banda Aceh coast is that once the intermittent forcing factors such as land subsidence and tsunami occurred in the coastal system, the coastal morphology will be reset to a new state, and subsequently will start the new development hereafter. From history we learned that for such type of tsunami-affected coast, the future development of the coast in the hundred years will experience the shoreline re-orientation and changing position under the influence of the continuous forcing factors such as wave actions, currents, tides and sea-level rise. In addition to this, it also will likely face disruption of the morphological development trend by the intermittent forcing factors by the tsunami and/or land subsidence. This is in agreement with the statement in geomorphological context by Verstappen (2000) that the geomorphological effects of the prevailing climatic conditions in Indonesia are most marked in the more or less cratogene parts, but rank second in importance as a geomorphological factor (after the structural elements) in the belts where neotectonism is dominant.

In a coastal region where tectonics is not active, extreme tides, coastal morphological development may be controlled by extreme tides, seasonal variations of wave climate, storm surge or hurricane. Studies on the impacts of such forcing factors (e.g. Morton, et al. 1994; Larson, 1991; Niedoroda and Swift, 1991; Dean and Maumeyer, 1983; Hallermeier, 1981; etc.) are more advanced 
compared to that of tsunami or sudden land subsidence. Many methods have been established for analysing various types of events which follows different statistical distributions. Areas especially prone to these forcing factors are wide shallow areas, e.g. the North Sea, Danish West Coast or Southern Coast of US. For this type of coast, a long-term trend morphological development may still be possible to forecast; e.g. controlled by the sea-level rise. For instance, in Danish West Coast (Mangor, 2004), a scenario made for an increase of $50 \mathrm{~cm}$ sea-level rise at the end of a century decreases the recurrence period from 100 years to 20 years for flooding of a dike. This scenario was simply made by applying the merely a linear trend of sea-level rise. Some interruptions of storms or hurricanes can be predicted better by statistical information available.

In Chapter 4, the long-term trend forecast is impossible without taking into account the impact due to the tsunami and/or rapid land subsidence. Thus, the morphological development of a tectonically active region is highly staggered. We learned that if the linear trend of sea-level rise was wrongly taken into account in the coastal management practice for this coastal area, the shoreline recession in this period may be underestimated. This is because the effect of the frequent tsunami or land subsidence may change this trend that gives a deteriorating effect than expected. To some extent, such an impact is also similar for a coast that was hit by a severe hurricane (e.g. Hurricane Katrina in New Orleans), particularly since the location is a low-lying coast. It was also mentioned in Chapter 3, that the recovery process of a sand-rich coastal environment from a tsunami is somewhat similar to that from a hurricane (Morton, et al., 1994).

Overall, this also implies that while the whole world at present has raised awareness on the impact of the global warming leading to the eustatic sea-level rise, at the same time, the tectonically active region such as the Indian Ocean region may suffer the other inevitable hazard by the earthquakes and tsunamis. 


\section{Chapter 6}

\section{Conclusions and recommendations}

The earthquake and subsequent tsunami of 26 December 2004 caused a dramatic change in the morphology of the affected coasts bordering the Indian Ocean. Little was known about the geomorphological history of the Banda Aceh coastal plain. The objective of this study was stated in the Introduction, Chapter 1, as:

The objective of this thesis is to increase the understanding of how the large-scale natural interventions such as tsunami and tectonic land subsidence control the future development of the coastal morphology with different underlying geomorphic settings.

Three main research questions were formulated accordingly and the answers are provided in the conclusions below.

\subsection{Conclusions}

RQ 1: Which coastal units can we distinguish at the Banda Aceh coast and are there differences in their response to the earthquake and tsunami?

Motivated by the absence of information about the actual characteristics of the coastal morphology of Banda Aceh, the insight about the geomorphic settings and the extent of the effect of earthquake leading to tsunami of 26 December 2004 to the coastal morphology was investigated in Chapter 2 of the thesis. The modern shoreface of the Banda Aceh coast is a sand-poor environment consisting only a thin layer of mobile sediment over a consolidated prograding delta developed during the Holocene.

The seabed geomorphic setting as indicated by the profiles is variable along this $25-\mathrm{km}$ coastal stretch. The convexity of the shoreface determines that the shoreface of the southwestern portion of the coast was influenced by the alluvial progradation during the Holocene and is also tectonically unstable. On the 
other hand, the influence of marine regression was more prominent during the same period in the tectonically stable northeastern portion, which resulted in a concave shoreface profile. These differences in geomorphic settings as well as the sediment characteristics in the littoral zone resulted from different profile responses to the earthquake and tsunami, thus influencing subsequent morphological development.

Besides the extensive inundation of seawater to the coastal plain during the tsunami, the impact of the earthquake and tsunami also affected the morphological units that have been established in the Holocene period (e.g. the breached old beach ridges and cropped-out older shoreface deposits).

\section{RQ 2: How has the coast developed after the tsunami so far (i.e., on a relatively short time scale)?}

Initial field observation and preliminary spatial data investigations in the early posttsunami periods led to thorough understanding of the response of different coasts due to the earthquake and tsunami in a short time scale. The coast after being affected by such a sudden change in morphology experiences short-term morphological adjustment, before returning to its original transport capacity (i.e. in the littoral transport rate).

This short-term morphological development may lead to a contrasting behaviour under different geomorphic settings. After 6 months, a sand-poor environment such as Ulee Lheue on the northwest coast experienced ongoing erosion of about $15 \%$ of the total sediment loss by the tsunami. We also suspected that the ongoing shoreline retreat in this respect has partially to do with the effect of land subsidence. On the other hand, $60 \%$ of the total sediment loss due to the tsunami was restored to a sand-rich environment of Lampu Uk on the west coast.

The slope gradient and width of the shoreface in front of each coast control this contrasting behaviour. The littoral transport will require a transient adjustment of morphology which can be in the form of shoreline position reorientation and the smoothening of shoreface. Nevertheless, because of the severely eroded coasts due to tsunami and, to some extent, due to land subsidence this was not necessarily accompanied by the return of shoreline to the pre-tsunami position.

In this study, data such as an aerial photos mosaic, satellite images, bathymetry and coastal topography at certain points in time before and after the tsunami (2001 to 2007) were used to analyse the direct impact of the tsunami and 
the short-term ( $\sim 2$ years) morphological development of the coasts since the tsunami. All the data involved in this study were processed through GIS-based procedures such as geo-referencing, shoreline digitizing, and DEM generation. In addition, two field visits were conducted in June 2005 and August 2006. Data analysis and interpretation were validated using observations from the two fieldworks and additional information from the literature.

\section{RQ 3: What kind of variability is expected in the morphological development of the coast in the next century?}

Once the intermittent forcing factors such as land subsidence and tsunami occurred in the coastal system, they will reset the coastal morphology to a new state, and subsequently will start the new development hereafter. The investigation on the shoreline evolution of Banda Aceh coast in the past century answers the variability expected to occur in the morphological development of the coast on a time scale of a century. Tectonic activities were responsible for remarkable variability of shoreline recession rates within the past century, either by the influence of land subsidence or by the small-scale tsunami waves. The analysis of the morphological development of the Banda Aceh coast in this thesis has given sufficient evidence and indications of the influence of the tsunami and land subsidence on the coastal morphological development.

Even though the time interval of a large magnitude tsunami such as the December 2004 tsunami in this study (>600 years) exceeds that of the tectonic strain release maximum return period (200 years), nevertheless, smaller magnitudes of tsunamis and land subsidence are apparently not rare after all. In a tectonically active region such as the Banda Aceh coast, the trend of the coastal morphology in a century may be altered by either a tsunami or tectonic subsidence.

Frequent earthquakes causing high probability of land subsidence and tsunami recurrence (20 to 30 years) can be the worst scenario for the development of a tsunami-affected coastal morphology in the next hundred years. The rate of shoreline retreat caused by tectonic land subsidence effect was remarkable at the tectonically unstable part of Banda Aceh coast, which equalled $-46 \mathrm{~m} /$ event. The small magnitude of tsunami events in the past century inferred a significant amount of shoreline retreat at the tectonically stable coastal section which can be up to $-27 \mathrm{~m} /$ event. These rates of (sudden) shoreline position change are relatively higher than that due to gradual sea level rise in this region for any scenario. This suggests that the damage caused by probable recurrence of tsunami and land 
subsidence events to the coastal morphology within a century can be an order of magnitude greater than the effect of the well-known sea-level rise due to global climate change, which is often considered important in modern coastal management practices.

\section{Finally, has the objective been achieved?}

This study has provided comprehensive analysis to increase the understanding of the future development of a coastal system that is prone to the large-scale natural interventions of tectonic land subsidence and tsunami. The hypothesis of the longer the time scale being considered, the more forcing factors with different frequencies are involved in the coastal morphological development has been confirmed to be true by analysing the morphological development of the coastal area in various time-scales. This thesis also provides the analysis results of the morphological development of the coast coupling the continuous and intermittent forcing factors in a hundred-year time scale in the past. From this analysis we understand how the intermittent forcing factors interrupt the long-term trend of morphological development by the continuous forcing factors. Understanding these, the possible future morphological development can be drawn in the alternative scenarios.

The main challenge in this thesis relates to the lack of readily available knowledge of the pre-existing geomorphology of the affected coast. This has been tackled by the exploratory methodologies that provide a proxy of the non-existent data sources (shoreface and beach sediment characteristics and geomorphic settings) and most importantly as a proxy of the non-existent explanation of the phenomena (e.g. the impact of tsunami and earthquakes on the coastal system). This results in narrowing the knowledge gaps by being able to determine the extent of morphological destruction due to the earthquake and tsunami, to characterize the coastal geomorphic settings and sediment characteristics, and to quantify the probable magnitudes and frequencies of earthquake and tsunami events in different time scale of interests. In this way, we built a sound coastal morphological foundation to inform important aspects necessary to be taken into account in coastal engineering and management practices for the tectonically active coastal region. 


\subsection{Recommendations}

The thesis provides the results of coastal system analysis encompassing geomorphological as well as engineering perspective towards a concept for future coastal development of a tectonically active coastal region which is subjected to recurrence of earthquakes and tsunamis.

The cascade model of morphological units, which resulted from the geomorphological study at the Banda Aceh coast, established the framework to investigate the geomorphic settings of the coastal system. This serves as an informative tool to determine the route of further research to isolate important processes and forcing factors involved in the morphological development of the coast in different time and spatial scale. Following this framework, the uncertainty resulted from the unknown mechanism or process has therefore been reduced, and can be further reduced by further research and field investigations to obtain the agreement to the geomorphological interpretations made in this thesis. Basic lines of further research might be pursued in the study of a higher resolution of both spatial and temporal data (e.g. from remote sensing and GIS data), to investigate the signs of submergence of geological structure of the tectonically active region. In-situ sampling and seismic signals interpretation might also be utilized to perform a better interpretation of the morphological development, and if possible, to distinguish the morphological characteristics associated with tsunami, tectonic land subsidence (or uplift) and liquefaction effect.

The concept for future forecast of the coastal development of the tsunami-affected coast in this thesis was developed restrictedly based on interpretations of such phenomena from multi-source spatial data, records of their occurrences and magnitude, and geomorphological interpretations. We propose the subsequent step of the research should be to validate the geomorphological interpretations by conducting in-situ data measurements such as carbon-dating (C14). The cascade model in Chapter 2 provides the framework for selecting the locations of the samples and what kind of deposits characteristics expected at those locations.

Despite the simple future scenarios provided in this study, the approach serves adequate knowledge to represent the morphological phenomena and development of a coast after being affected by tsunamis and land subsidence. Further task will be to put this concept to a test by, for instance, establishing morphological modeling sort of a Large Scale Coastal Behaviour (LSCB) where important forcing factors will be appropriately assigned for the coastal morphological development in the time scales of interest. For this purpose, 
conventional principals which use the sea level rise as a controlling factor for the gradual changes in the coastal morphology (e.g. Cowell, 1999; Niedoroda, 1995) should not be used without precautions. This is because the morphological development of a tectonically active region is highly staggered due to sudden influence of the intermittent forcing factors such as tsunami and rapid/sudden land subsidence. This means that modeling of coastal morphological development in a medium or long term scale based on an expected long-term trend (e.g. of gradual sea level rise) is no longer applicable in this case. New approach to accommodate the intermittent forcing factors in the morphological modeling is therefore worth pursued.

Further integration of this preliminary findings and analysis of the tsunami-related research should be further discussed and exchanged in a broader scientific environment to be able to apply them as sound-engineering management information to mitigate or to reduce the risk of such phenomenal hazard on the coastal region in the future.

Finally, this thesis provides sufficient information for coastal managers for the coastal region. In a local level, coastal managers to make decision on the coastal safety measures based on the knowledge of the coastal area of Banda Aceh provided in this thesis. One important remark implied from the geomorphological analysis in this study is that, one might reconsider whether to construct a largescale coastal structure or to make new master-plan involving inhabitant relocation away from the low-lying coast to prevent similar casualties to that caused by the large-scale tsunami of December 2004. Accordingly, the subsequent step is to focus a comprehensive risk assessment to seek for preventive coastal safety measures based on the knowledge and future scenarios provided by this thesis.

In the national and global levels, we recommend that one should foreseen the coastal problems in Indonesia not only related to the effect of the eustatic sealevel rise acceleration, but also to pay attention to the same or even worse effect of the tectonic subsidence and small magnitude tsunamis that expected to occur frequently in future hundred years, particularly, in the coastal region associated with the subduction zones. 


\section{References}

UP-PSDA (2003) Report on oceanography measurements and wave analysis. Detail design of Syiah Kuala beach, Banda Aceh City, Flood and coastal safety project, Civil Work Department, Nanggroe Aceh Darussalam, Province, Banda Aceh. (In Indonesian).

Anonymous (1997) Report on oceanography parameter measurements and wave analysis. Detail design of beach revetment of Lampu Uk beach, Great Aceh. Western coastal safety project, Civil Work Department, Aceh Province, Banda Aceh.

Abe, K. et al. (1993) Field survey of the Nicaragua earthquake and tsunami of September 2, 1992, Bulletin Earthquakes Research Institute Tokyo University, 68: 23-70.

Abe, K., Hakuno, M., Takeuchi, M., and Katada, T. (1986) Survey report on the tsunami of the Michoacan, Mexico earthquake of September 19, 1985, Bulletin Earthquake Research Institute Tokyo University, 61: 475-481.

Anonymous (1997) Report on oceanography parameter measurements and wave analysis. Detail design of beach revetment of Lampu Uk beach, Great Aceh. Western coastal safety project, Civil Work Department, Nanggroe Aceh Darussalam Province, Banda Aceh. (In Indonesian).

Baker, R.G.V., Haworth, R.J. and Flood, P.G. (2001) Inter-tidal fixed indicators of former Holocene sea-levels in Australia: a summary of sites and a review of methods and models. In: Woodroffe, S.A. and Horton, B.P. (2005) Holocene sea-level changes in the Indo-Pacific. Journal of Asian Earth Science, 25: 29-43.

Bemmelen, R.W.van. (1949) The geology of Indonesia (2 volumes). Gvt Print Office, The Hague.

Berninghausen, W. H. (1962) Tsunamis reported from the west coast of South America, In: Ramirez, F.J., Perez, P.C., 2004. The Local Tsunami Alert System [“SLAT']: A Computational Tool for the Integral Management of a Tsunami Emergency. Natural Hazard, 31: 129-142.

Bird, E. (2000) Coastal geomorphology: An Introduction. Wiley, West Sussex.

Birkemeier, W.A.. (1985) Field data on the seaward limit of profile change. Journal of Waterway, Port, Coastal and Ocean Engineering, 111: 598 - 602.

Boak, E.H. and Turner, I.L. (2005) Shoreline definition and detection: A Review. Journal of Coastal Research, 21(4): 688-703.

Borrero, J.C., Bu, J., Saiang, C., Uslu, B., Freckman, J., Gomer, B., Okal, E.A. and Synolakis, C.E. (2003) Field survey and preliminary modeling of the Wewak, Papua 
New Guinea earthquake and tsunami of September 9, 2002. Seismological Research Letter, 74: 393-405.

Borrero, J.C., Ortiz, M., Titov, V. and Synolakis, C. (1997) Field survey of Mexican tsunami produces new data, unusual photos. EOS, Trans. Am geophyis. Un., 78, 85: 87-88.

Bruun, P., (1962) Sea-level rise as a cause of shore erosion. Journal of Waterways, Harbors Division, ASCE, 88: 117-130.

CERC (1992), Automated Coastal Engineering System, Volume I: Technical Reference; Vol II: User's Guide, Department of the Army Water-way Experiment Station, Corps of Engineers, Mississippi.

Cooper, J.A.G. and Pilkey, O.H. (2004) Sea-level rise and shoreline retreat: time to abandon the Bruun Rule. Global and Planetary Change, 43: 157-171.

Cowell, P.J. Roy, P.S., Jones, R.A. (1995) Simulation of large-scale coastal change using a morphological behaviour model, Marine Geology, 125: 45-61.

Curray, J.R. (2005) Tectonics and history of the Andaman Sea region. Journal of Asian Earth Science, 25: $187-232$.

Dean, R.G. and Maurmeyer, E.M. (1983) Models of beach profile response. In: P. Komar and J. Moore (Editors), CRC Handbook of Coastal Processes and Erosion. CRC Press, Boca Raton: 151-165.

Dohmen-Janssen, C.M., Meilianda, E., Maathuis, B.H.P. and Wong, P.P. (2006) State of Banda Aceh beach before and after the tsunami. Proceeding of $30^{\text {th }}$ International Conference on Coastal Engineering, ASCE, Sand Diego, California.

Dolan, R., Hayden, B. and Heywood, J. (1978) A new photogrammetric method for determining shoreline erosion. Coastal Engineering, 2: 21-39.

Dominey-Howes, D., Cummins, P. and Burbidge, D. (2007) Historic records of teletsunami in the Indian Ocean and insights from numerical modelling. Natural Hazards, 42:1-17.

Fagherazzi, S. and Du, X. (2007) Tsunamigenic incisions produced by the December 2004 earthquake along the coasts of Thailand, Indonesia and Sri Lanka. Geomorphology, 99(1-4): 120-129.

Farris, A.S. and List, J.H. (2007) Shoreline change as a proxy for subaerial beach volume change. Journal of Coastal Research, 23(3): 740-748.

Fenneman, N.M. (1902) Development of the profile of equilibrium of the subaqueous shore terrace. In: Niedoroda, A.W., Reed, C.W., Swift, D.J.P., Arato, H. and Hoyanagi, K. (1995) Modeling shore-normal large-scale coastal evolution. Marine Geology, 126: 181-199. 
Gelfenbaum, G. and Jaffe, B. (2003) Erosion and sedimentation from the 17 July, 1998 Papua New Guinea tsunami. Pure and Applied Geophysics, 160(10-11): 1969-1999.

Geyh, M.A., Kudrass, H.R. and Streif, H. (1979) Sea-level changes during the late Pleistocene and Holocene in the Strait of Malacca. Nature, 278(5703): 441 - 443.

Gibbons, H. and Gelfenbaum, G. (2005) Astonishing wave heights among the findings of an international tsunami survey team on Sumatra. Sound Waves, March 2005 (monthly newsletter), http://soundwaves.usgs.gov/2005/03/

Gutenberg, B. (1939) Tsunamis and earthquakes. In: Okal, E.A. and Synolakis, C.E. (2004) Source discriminants for near-field tsunamis. Geophysical Journal International, 158: 899-912.

Jaffe, B.E., Borrero, J.C., Prasetya, G.S., Peters, R., McAdoo, B., Gelfenbaum, G., Morton, R., Ruggiero, P., Higman, B., Dengler, L., Hidayat, R., Kingsley, E., Kongko, W., Lukijanto, Moore, A., Titov, V. and Yulianto, E. (2006) Northwest Sumatra and Offshore Islands Field Survey after the December 2004 Indian Ocean Tsunami. Earthquake Spectra, 22(S3): 105-135.

Hallermeier, R.J. (1981) A profile zonation for seasonal sand beaches from wave climate, Coastal Engineering, 4: 253-277.

Hesp, P.A., Hung, C.C., Hilton, M. , Ming, C.L. and Turner, I.M. (1998) A first tentative Holocene sea-level curve for Singapore. Journal of Coastal Research, 14(1): 308-314.

Hulscher, S.J.M.H. (2003) Summary of papers on predicting aggregated-scale coastal evolution, Journal of Coastal Research, 19(4): 755-756.

IPCC (2007) Climate Change 2007: The physical science basis. Contribution of Working Group I to the Fourth Assessment Report of the Intergovernmental Panel on Climate Change [Solomon, S., D. Qin, M. Manning (eds.)].

Kanamori, H. and Kikuchi, M. (1993) The 1992 Nicaragua earthquake; a slow tsunami earthquake associated with subducted sediments. Nature, 361: 714-716.

Komar, P.D. (1998) Beach processes and sedimentation. Prentice Hall, New Jersey.

Larson, M. (1991) Equilibrium profile of a beach with varying grain size. Proceeding of Coastal Sediment 1991, ASCE: 905-919.

Lee, W.H.K., Meyers, H. and Shimzaki, K. (Eds.) (1988) Historical Seismograms and Earthquakes of the World. Academic Press, Inc., San Diego, California.

Mangor, K. (2004) Shoreline management guidelines. DHI Water \& Environment, Hørsholm. 
McKinnon, E.E. (1988) Beyond Serandib: a note on Lambri at the northern tip of Aceh, Indonesia. Southeast Asia Program, Cornell University, 46: 103-121.

Meilianda, E., Wong, P.P. and Dohmen-Janssen, C.M. (2006) Indications of coastal morphological changes on Banda Aceh coast as responses to the earthquake and the tsunami. In: Book of Abstract of NCK-Days, 23-24 March 2006 in Kijkduin.

Meleo, J.F. (1994) Shoreface variability in Southeastern Australia. In: Short, A.D. (1999) Handbook of beach and shoreface morphodynamics. Wiley, England.

Meltzner, A.J., Sieh, K., Abrams, M., Agnew, D.C., Hudnut, K.W., Avouac, J. and Natawidjaja, D.H. (2006) Uplift and subsidence associated with the great AcehAndaman earthquake of 2004. Journal of Geophysical Research, 111: B02407.

Mitrovica, J.X. and Peltier, W.R. (1991) On postglacial geoid subsidence over the equatorial oceans. Journal of Geophysical Research, 96(B12): 20053 - 20071.

Monecke, K., Finger, W., Klarer, D., Kongko, W., McAdoo, B.G., Moore, A.L. and Sudrajat, S.U. (2008) A 1000-year sediment record of tsunami recurrence in northern Sumatra. Nature (Letter), 455: 1232-1234.

Montagne, D.G. (1950) Het terrassenlandschap van de Atjebvallei tusschen Seulimeum en Indrapuri, gezien vanuit de lucht. Instituut Geografi Djatop., Publ. 3. Jakarta, Indonesia.

Moore, L.J., Ruggiero, P. and List, J.H. (2006) Comparing mean high water and high water line shorelines: should proxy-datum offsets be incorporated into shoreline change analysis? Journal of Coastal Research, 22(4): 894-905.

Morton, R.A., Paine, J.G. and Gibeaut, J.C. (1994) Stages and durations of post-storm recovery, southeastern Texas coast, USA. Journal of Coastal Research, 10: 214-226.

Morton, R.A. (1979) Temporal and spatial variations in shoreline changes and their implications, examples from the Texas Gulf Coast. In: Moore, L.J., Ruggiero, P. and List, J.H. (2006) Comparing mean high water and high water line shorelines: should proxy-datum offsets be incorporated into shoreline change analysis? Journal of Coastal Research, 22(4): 894-905.

Murty, T. (1984) Tsunamis in the Andaman Sea. Institute of Ocean Sciences, Dept. of Fisheries and Oceans, Sidney.

Narayana, A.C., Tatavarti, R., Shinu, N. and Subeer, A. (2007) Tsunami of December 26, 2004 on the southwest coast of India: Post-tsunami geomorphic and sediment characteristics. Marine Geology, 242: 155-168.

Natawidjaja, D.H., Sieh, K., Galetzka, J., Suwargadi, B.W., Cheng, H., Edwards, R.L., and Chlieh, M. (2007) Interseismic deformation above the Sunda Megathrust recorded in coral microatolls of the Mentawai islands, West Sumatra. Journal of geophysical research, Vol. 112, B02404: 1-27. 
Neprochnov, Y.P. (1964) The structure and thickness of the sedimentary layer of the Arabian Sea, the Bay of Bengal and the Andaman Sea. In: Rodolfo, K.S. (1969) Sediments of the Andaman Basin, northeastern Indian Ocean. Marine Geology, 7: 371-402.

NGDC-NOAA (2008) Tsunami events full search, sort by date, country. http://www.ngdc.noaa.gov

Niedoroda, A.W., Reed, C.W., Swift, D.J.P., Arato, H. and Hoyanagi, K. (1995) Modeling shore-normal large-scale coastal evolution. Marine Geology, 126: 181-199.

Niedoroda, A.W. and Swift, D.J.P. (1991) Shoreface processes. In: Herbich, J.B. (ed) Handbook of coastal and ocean engineering, Vol. 2, Gulf Publ. Co., Houston, USA pp. $735-770$.

Niedoroda. A.W., Swift, D.J.P. and Hopkins, T.S. (1985) The Shoreface. In: Davis, R.A. (Ed.), Coastal Sedimentary Environments, $2^{\text {nd }}$ ed., Springer, New York.

Noda, A., Katayama, H., Sagayama, T., Suga, K., Uchida, Y., Satake, K., Abe, K. and Okamura, Y. (2007) Evaluation of tsunami impacts on shallow marine sediments: An example from the tsunami caused by the 2003 Tokachi-oki earthquake, northern Japan. Sedimentary Geology, 200 (3-4): 314-327.

Okal, E.A. and Synolakis, C.E. (2004) Source discriminants for near-field tsunamis. Geophysical Journal International, 158: 899-912.

Pararas-Carayannis, G. (2005) Earthquake and tsunami of June 26, 1941 in the Andaman Sea and the Bay of Bengal.

(http://www.drgeorgepc.com/Tsunami1941AndamanIslands.html)

Paris, R., Wassmer, P., Sartohadi, J., Lavigne, F., Barthomeuf, B., Desgages, E., Grancher, D. Baumert, P., Vautier, F., Brunstein, D. and Gomez, C. (2009) Tsunamis as geomorphic crises: Lessons from the December 26, 2004 tsunami in Lhok Nga, West Banda Aceh (Sumatra, Indonesia), Geomorphology, 104 (1-2): 59-72.

Paris, R., Lavigne, F., Wassmer, P. and Sartohadi, J. (2007) Coastal sedimentation associated with the December 26, 2004 tsunami in Lhok Nga, west Banda Aceh (Sumatra, Indonesia). Marine Geology, 238: 93-106.

Philpott, K.L. (1984) Comparison of cohesive coasts and beach coasts. In: Sunamura, T. (1992) Geomorphology of rocky coasts. Wiley, England.

Rajendran, K., et al. (2008) Age estimates of coastal terraces in the Andaman and Nicobar islands and their tectonic implications. Tectonophysics, 455: 53-60. 
Ramirez, F.J. and Perez, P.C. (2004 The Local Tsunami Alert System [“SLAT”]: A Computational Tool for the Integral Management of a Tsunami Emergency. Natural Hazard, 31: 129-142.

Riggs, S.R., Cleary, W.J. and Snyder, S.W. (1995) Influence of inherited geologic framework on barrier shoreface morphology and dynamics. Marine Geology, 126: 213 - 234.

Rodolfo, K.S. (1969) Sediments of the Andaman Basin, northeastern Indian Ocean. Marine Geology, 7: 371-402.

Rosati, J.D. (2005) Concepts in sediment budgets. Journal of Coastal Researc, 21(2): 307-322.

Sallenger, A., Wright, C.W. and Lillycrop, J. (2007) Coastal-change impacts during Hurricane Katrina: An overview. Proceeding of the $6^{\text {th }}$ International Symposium on Coastal Engineering and science of coastal sediment processes, 13-17 May 2007, New Orleans.

Satake, K. and Tanioka, Y. (2003) The July 1998 Papua New Guinea earthquake: mechanism and quantification of unusual tsunami generation. Pure applied Geophysics, 160: 2082-2118.

Satake, K. and Kanamori, H. (1991) Abnormal tsunamis caused by the June 13, 1984, Torishima, Japan, earthquake. Journal Geophyisical Research, 96: 19933-19939.

Schumm, S.A., Mosley, M.P. and Weaver, W.E. (1987) Experimental fluvial geomorphology. John-Wiley and Sons, New York.

Sieh, K. and Natawidjaja, D.H. (2000) Neotectonics of the Sumatran fault, Indonesia. Journal of Geophysical Research, 105 (B12): 28295 - 28326.

Sinsakul, S. (1990) Evidence of sea-level changes in the coastal area of Thailand: A review. In: Tjia, H.D. (1992) Holocene sea-level changes in the Malay-Thai Peninsula, a tectonically stable environment. Geology Society of Malaysia, 31: 157-176.

Short, A.D. (1999) Handbook of beach and shoreface morphodynamics. Wiley, England.

Smith, G.L. and Zarillo, G.A. (1990) Calculating long-term shoreline recession rates using aerial photographic and beach profiling techniques. Journal of Coastal Research, 6(1): 111-120.

Soloviev, S. L. and Go, Ch. N. (1969) Catalog of Tsunamis in the Pacific (main data). In: Ramirez, F.J. and Perez, P.C. (2004) The Local Tsunami Alert System [“SLAT”]: A computational tool for the integral management of a tsunami emergency. Natural Hazard, 31: 129-142.

Stafford, D. B. (1971) An aerial photographic technique for beach erosion surveys in North Carolina. U.S. Army Corps of Engineers, Coastal Engineering Research Center, 115p. In: Moore, L.J., Ruggiero, P. and List, J.H. (2006) Comparing mean high water and high water line shorelines: should proxy-datum offsets be incorporated into shoreline change analysis? Journal of Coastal Research, 22(4): 894-905. 
Stein, S. and Okal, E.A. (2005) Speed and size of the Sumatra earthquake. Nature, 434: 581582.

Sunamura, T. (1992) Geomorphology of rocky coasts. Wiley, England.

Sweet, S. and Silver, E.A. (2003) Tectonics and slumping in the source region of the 1998 Papua New Guinea tsunami from seismic reflection images. Pure applied Geophysics, 160: $1945-1968$.

Swift, D.J.P. (1976) Continental shelf sedimentation. In: Stanley, D., Swift, D.J.P. (Eds.), Marine Sediment Transport and Environmental Management. John Wiley \& Sons, New York.

Tjia, H.D. (1992) Holocene sea-level changes in the Malay-Thai Peninsula, a tectonically stable environment. Geology Society of Malaysia, 31: 157-176.

Tjia, H. D. and Fujii, S. (1989) Late Quaternary shorelines in Peninsular Malaysia. In: Tjia, H.D. (1992) Holocene sea-level changes in the Malay-Thai Peninsula, a tectonically stable environment. Geology Society of Malaysia, 31: 157-176.

Tjia, H.D. (1977) Tectonic depressions along the transcurrent Sumatra fault zone. In: Verstappen, H. Th. (2000) Outline of the geomorphology of Indonesia. A case study on tropical geomorphology of a tectogene region. ITC Publication No. 79, Enschede.

Umbgrove, J. H. F. (1948) The origin of deep-sea troughs in the East Indies. In: Rodolfo, K.S. (1969) Sediments of the Andaman Basin, northeastern Indian Ocean. Marine. Geology, 7: 371-402.

Umitsu, M., Tanavud, C. and Patanakanog, B. (2007) Effects of landforms on tsunami flow in the plains of Banda Aceh, Indonesia, and Nam Khem, Thailand. Marine Geology, 242: $141-153$.

Verstappen, H. Th. (2000) Outline of the geomorphology of Indonesia. A case study on tropical geomorphology of a tectogene region. ITC Publication No. 79, Enschede.

Verstappen, H. Th. (1980) Quaternary climatic changes and natural environment in Southeast Asia. GeoJournal, 4.1: 45-54.

Verstappen, H. Th. (1973) A geomorphological reconnaissance of Sumatra and adjacent islands. Wolters-Noordhof Publication, Groningen.

Verstappen, H. Th. (1953) Djakarta Bay: A geomorphological study on shoreline development. Ph D Thesis, University of Utrecht, Utrecht.

Waltham, T. (2005) The Asian Tsunami disaster, December 2004. Geology Today, 21(1): 2226. 
Wang, P., Kirby, J.H., Haber, J.D., Horwitz, M.H., Knorr, P.O. and Krock, J.R. (2006) Morphological and sedimentological impacts of hurricane Ivan and immediate poststorm beach recovery along the northwestern Florida Barrier-Island Coasts. Journal of Coastal Research, 22(6): 1382-1402.

Woodroffe, S.A. and Horton, B.P. (2005) Holocene sea-level changes in the Indo-Pacific. Journal of Asian Earth Science, 25: 29-43.

Woodroffe, S.A. and McLean, R. (1990) Microatolls and recent sea-level change on coral atolls. Nature, 344: 531-534.

Zhang, K., Whitman, D., Leatherman, S. and Robertson, W. (2005) Quantification of beach changes caused by hurricane Floyd along Florida's coast using Airborne laser surveys. Journal of Coastal Research, 21(1): 123-134. 


\section{Acknowledgements}

I never knew that many aspects in my life could change within five years of my $\mathrm{Ph} \mathrm{D}$ research. Fate led me to get into contact with my promoter, Prof. Suzanne Hulscher, in summer 2003. It was started when for the first time ever I travelled across two continents to have a one-week interview for a $\mathrm{Ph} \mathrm{D}$ position in Water Engineering and Management Group at the University of Twente. The research proposal was about the Integrated Coastal Zone Management of Banda Aceh beach, Sumatra, Indonesia. It was eight months after eventually I started this project, the large magnitude earthquake and tsunami hit my hometown, Banda Aceh city, on 26 December 2004. Everything's changed ever since, both in life and research. I could have not completed this thesis without the help and supports of many people, which therefore I would like to thank them.

First of all my thanks go to my promotor Prof. Suzanne Hulscher. Suzanna, thank you for giving me the opportunity to come back strong to restart my research to a new avenue and at the same time gave me freedom to roam a wide range of approach to produce this thesis. I always appreciate your professional vision of 'giving opportunity to people' to make me realize the reason of being here and to keep me focus on my goal. Furthermore, without your confirmation to let me come to the Netherlands together with my family from the beginning, this thesis would have never been existed. To my daily supervisor and co-promotor, Dr. Marjolein Dohmen-Janssen, I would like to thank you for never giving up on me and for supporting me when I was in my lowest points of despair, and for helping me standing up again to finish what I have already started. No matter how winding the road was I could find a way with your warm, yet firm and stimulating guidance throughout my Ph D research. Marjolein, you always have solutions to any problem.

It was post-tsunami when I was introduced to Dr. Ben Maathuis, my external supervisor from ITC. Ben, I would never survive entering a completely new avenue of my research involving GIS and remote sensing without your intensive hands-on tutorial during my stay in ITC. Our discussions on many aspects in physical geography challenged me to dare discovering the unknowns about the morphology of Banda Aceh coast. I was also honored to have discussed my research to Prof. Herman Verstappen with whom I had a further journey to the past of Sumatra, Indonesia with his guidance. My thanks also go to Dr. Wong Poh Poh from the National University of Singapore who initiated the jointfieldworks in 2005 and 2006 in Banda Aceh and to let me learn to observe the coast through his geomorphological eyes. Thank you for all of you for such fascinating insights.

The progress of this thesis would have been sluggish without thorough discussions on the coastal processes with Dr. Jan Mulder and Dr. Kathelijne Wijnberg. Discussing coastal processes in different time scales with both of you always brought me to some new thoughts, ideas and triggered my curiousity. Jan and Kathelijne, thank you for guiding me to a fascinating insight on the coastal processes beyond my horizon. Kathelijne, we both know that working in a mother-style may never be similar to the others. I thank you for being such a wonderful office mate who understands the often-muted person against your back was trying to survive the only eight hours of her day for being just herself. Thanks also for sharing the motherhood experience.

During the two fieldworks to Banda Aceh, I was helped by many colleagues and acquaintance at the UP-PSDA of Syiah Kuala University and the Sea Defense Consortium of Bureau of Reconstructions and Rehabilitations (SDC-BRR) in Banda Aceh to collect data for my research. I thank them for their enthusiasm during those times. My 
acknowledgements are also addressed to the Sea Defence Consortium, BRR Aceh-Nias for providing the bathymetry, topography and other supporting data of the post-tsunami, to Bakosurtanal and JICA through the SIM-center BRR NAD Nias in providing the orthorectified aerial photo mosaic and the topographic map of June 2005. Last but not least in this list, it was exciting to discover the history of my hometown from the colonial maps from the KITLV Amsterdam. It was a wake up call for realizing how long ago it has been since Aceh geographically updated.

I would like to thank the following institutes which have financed my $\mathrm{Ph} D$ research. The University of Syiah Kuala for financing the first three and a-half years of my Ph D through the TPSDP Project. I'd like to thank Prof. Dr. Samsul Rizal, Dr. Alfiansyah Yulianur, Dr. Mustanir, Dr. Ismail AB, Danker Schaareman, and all the staff of TPSDP project at Syiah Kuala University, whom without their hard works to go against all odds within the project system, I would never survive just a decent life in the first three-and-ahalf years in the Netherlands. Also, in the last years of my Ph D project I was financially supported by The University of Twente (UT) through IGS Institute which I am really grateful for the initiative.

Many thanks to the rest of my doctoral committee members; Dr.Ir. Denie Augustijn, Prof. Ir. Eelco van Beek, Prof.dr. Piet Hoekstra and Prof.dr. Salomon Kroonenberg for accepting to be part of the committee during this very special day of my $\mathrm{Ph} \mathrm{D}$ defense, also for reading and making time for comments and suggestions.

I met very nice colleagues in the past five years, both in UT and ITC. I would first like to thank Daniella Noordam, who became my first contact person to get access to the starter kit of our new life in Enschede. Daniella, thanks for your tour-guide skill to take us dealing with the alien administration stuff. Most importantly, for literally knocking on my door more than an hour earlier in the morning for my first day meeting in WEM department; on the first day of the summer time switch. This one beats the jetlag! To Pieter van Oel, thank you for your generous help in the 'verhuizing dag' in the summer of 2005. Many thanks to Jolanthe Schretlen for her time in translating the 'sammenvatting'. My special thanks to Anna Wesselink, for whom I most indebted for her generous friendship and for helping us make the most of our stay in Enschede! To my former and current colleagues in WEM department of UT, thank you for all your supports during my two dark moments in my life which unfortunately happened during my $\mathrm{Ph} \mathrm{D}$ period. I wish I had more joyful times to share. But the less-than-two-handful of those gathering in lunches, WEM-uitjes, and dinners were plenty of nice memories for me. Moreover, I am grateful for being co-registered to ITC since 2006 to do my research in a Remote Sensing and GIS environment. To my friends and colleagues in WRS department of ITC, I thank you for your warm welcome and supports during those prosperous months.

Living in a small town Enschede was easy. I wish I could stay in a different state of life where I can get to know better the Dutch neighbours around. Nevertheless, having the Indonesian community in Enschede makes it worthwhile. I enjoyed the few times spent together with Tante Hadi and Oom Stan Krueger, Eko Hari Purnomo and family, Saiful and family, Ariando and family and Jamari. To 'anak-anak kost' Rinaldo Herlino, Adi Insani, Ahmad Junaedi and Faaris Mujaahid, thank you for being such nice boys in the house. Most importantly, thanks to Adisti 'Ceuceu' Rindayu and Purry Hidayaticka for being such sweet 'nannies' for Defan during those periods of struggle. After all, four seasons were not bad at all.

Life towards the end of my $\mathrm{Ph} \mathrm{D}$ has been wonderful, despite a short-term limbo of residency. I would like to thank my talented friend and my first paranimf, Irene Anggreeni, 
for the get-together lunches (with chipknip benefits) and for letting me share the 'uncommon' common sense. Thanks also to my dear friends and their families; Yossi Diantimala, Renny Anggraini, Wiwin Ambarwulan and last but not least to my second paranimf, Syarif Budhiman and his family for sharing joyful times travelling across the Western Europe in our last years. My special thanks go to Peter Fennema and Lucie Klein Breteler, for sharing the beautiful and encouraging moments towards the end of my stay in Enschede. Peter and Lucie, thanks for encouraging me to come out of my shell and for sharing the meaningful memories to bring home to. After all those rough months, our music projects were the best diversion and reward-deserving after all the stress.

To my sisters and brother, Yulia Direzkia, Dara Aldilla and Agam Abdilla, I might have hatched away from where you are, but YEAD KIDS spirit kept me alive in my journey in the past five years. Thank you for being there for Mama and Papa for me during all times of troubles, when I wished I could be there with you all instead. I sincerely thank my mother, Leilawaty Arief, and my late father, Jusli Daud, for giving me endless supports and pray for my educations and life. Mama, there is no way that I can make this through without reflection in how you took the battle in life when the sanity hanged by many obstacles, while raising your four children. Papa in Heaven, it was 11:30 hours on 24 March 2008 of Enschede time. Me in my kitchen, you on the other side of the international phone call, seven hours before you were away from this life; I knew I made you proud. What can I say?...bad things happen to good people like you. I thank God for having both of you in me.

Finally I would like to thank my beloved husband, Dedy Alfian, and my son, Defan Arifa, for being there with me from day one. Each and everyday, I felt really grateful to have both of you to go home to. Dedy, your heart is infinitely big for compromising, caring and accompanying me, and especially for understanding my worst state of being and metamorphosis during these rough, yet wonderful years. My little prince, Defan, by the time you want to read this thesis, I wish you would do more than what I achieved today.

This thesis is dedicated to all the victims of the tsunami on 26 December 2004. I hope it will be of useful information for the next generations.

It's been a privilege....

Enschede, 19 June 2009

Ella Meilianda 


\section{List of Publications}

\section{International scientific journals}

Meilianda, E. C.M. Dohmen-Janssen (in preparation). Development of a tectonically-active coastal area in a century. Part 1: Banda Aceh preceding the earthquake of 26 December 2004.

Meilianda, E, S.J.M.H. Hulscher (in preparation). Development of a tectonically-active coastal area in a century. Part 2: Future scenarios for Banda Aceh since the earthquake of 26 December 2004.

Meilianda, E., B.H.P. Maathuis, K.M., Wijnberg, J.P.M. Mulder, C.M. Dohmen-Janssen, S.J.M.H. Hulscher, (in preparation). History of Banda Aceh coast preceding the tsunami of 26 December 2004: A geomorphological outline.

Meilianda, E., C.M. Dohmen-Janssen, S.J.M.H. Hulscher, B.H.P. Maathuis, J.P.M. Mulder (conditionally accepted). Short-term morphological response and development of the Banda Aceh coast, Sumatra Island, Indonesia after the tsunami on 26 December 2004. Marine Geology.

\section{Conference proceedings}

Meilianda, E., C.M. Dohmen-Janssen, B.H.P. Maathuis, K.M. Wijnberg, S.J.M.H. Hulscher, J.P.M. Mulder (2008). Long-term development of a tsunami-affected coast. Proc. Physics of Estuary and Coastal Seas 2008, 25 - 29 August, 2008, Liverpool, United Kingdom.

Meilianda, E., C.M. Dohmen-Janssen and B.H.P. Maathuis (2007). Observation of morphological development on the tsunami-affected coast of Banda Aceh using multitemporal Digital Elevation Models. Proceeding of LAHR symposium River, Coastal and Estuarine Morphodynamics, RCEM 2007, 17-21 September 2007, Enschede, The Netherlands.

Meilianda, E., C.M. Dohmen-Janssen, B.H.P. Maathuis, S.J.M.H. Hulscher, and J.P.M. Mulder (2007). Beach Morphology at Banda Aceh, Indonesia in Response to the Tsunami on 26 December 2004. Proceeding of Coastal Sediments 2007, May 13-17, New Orleans, USA.

Dohmen-Janssen, C.M., E. Meilianda, B.H.P Maathuis and P.P. Wong (2006). State of Banda Aceh Beach before and after the Tsunami. Proceeding of the 30th International Conference on Coastal Engineering, ASCE, San Diego, California.

Meilianda, E., Wong, P.P. and Dohmen-Janssen, C.M. (2006) Indications of coastal morphological changes on Banda Aceh coast as responses to the earthquake and the tsunami. In: Book of Abstract of NCK-Days, 23-24 March 2006 in Kijkduin. 


\section{About the author}

Ella Meilianda was born in Banda Aceh, Sumatra, Indonesia on 30 May 1975. She spent her childhood in this very city until she graduated from the Syiah Kuala University, Banda Aceh as a Civil Engineer in 1999. Soon after the graduation, she was awarded a competitive fellowship for post-graduate studies under the DUE-Like Project, DIKTI by which she was prepared to become an academic staff in the Civil Engineering Department of Engineering Faculty at Syiah Kuala University. With this award, she continued her study in the Civil Engineering Department at Gadjah Mada University, Yogyakarta, Java, Indonesia. She graduated as a Master of Science in coastal engineering in 2001 with a Master thesis about a numerical model for combined wave

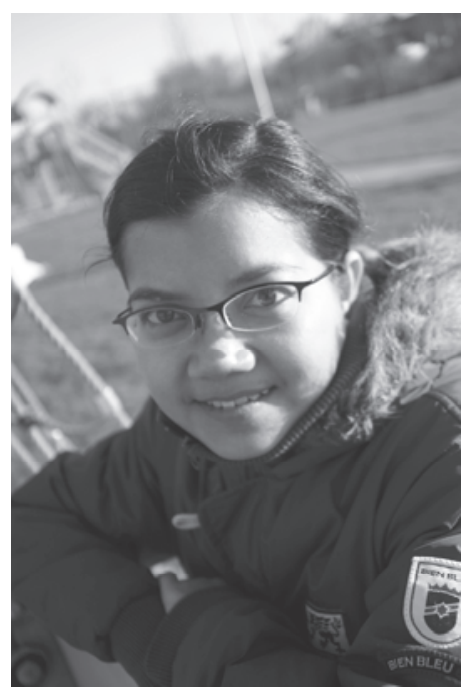
refraction-diffraction by parabolic equation. Immediately after graduation, she was entitled to return to her almamater in Syiah Kuala University as the academic staff. Besides doing research, her teaching activities were engineering mathematics, fluid mechanics, coastal engineering and water management for Bachelor degree, and some other water-related courses for Master degree. During this short return, she became interested in the management-related issues of a coastal zone, particularly of Banda Aceh. This met an opportunity in pursuing a Ph D research, when she received a fellowship award in 2003 under the TPSDP project from the Syiah Kuala University. She commenced her Ph D program in April 2004 in the Water Engineering Management (WEM) group at the University of Twente, Enschede, The Netherlands. Since the tsunami of December 2004, she decided to keep her interest to study the coast of her hometown resulting in a slight diversion from coastal management to coastal morphological development related to the tsunami event. After completing her Ph D research, she will return to the Syiah Kuala University in Banda Aceh to continue her career as an academic staff in the Civil Engineering Department. 
